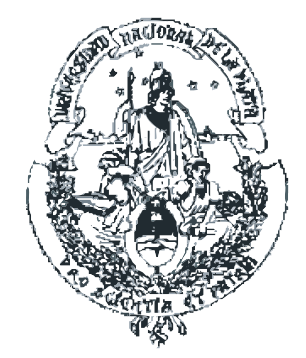

Universidad Nacional de La Plata

Facultad de Ciencias Naturales y Museo y Facultad de Ingeniería

Maestría en Evaluación Ambiental de Sistemas Hidrológicos

\title{
eco hidrología
}

\begin{abstract}
$\underline{\text { Tesis }}$
Evaluación ambiental de las condiciones de explotación y uso del recurso hídrico subterráneo en el barrio Cerro Los Leones, Tandil.
\end{abstract}

Alumna:

Lic. Corina Iris Rodriguez

Director:

Dr. V. Alejandro Ruiz de Galarreta

Co-directora:

Lic. Nilda González

2009 


\section{Gracias}

A las personas que colaboraron de distintas formas en este trabajo:

Adriana A. Díaz

V. Alejandro Ruiz de Galarreta

Anahí Tabera

Guillermina P. Jacinto

Elsa Marcela Guerrero

Marcelo R. Varni

Miguel Ángel Quiroga

Nilda González

Roberto D. Landa

Roberto Esteban Miguel

Rosario S. Barranquero

Roxana B. Banda Noriega

A los habitantes del Barrio Cerro Los Leones que me abrieron sus puertas.

Al personal de los Laboratorios de Análisis Bioquímicos y Minerales y de Microbiología de los Alimentos, Facultad de Ciencias Veterinarias - UNCPBA, por su colaboración y paciencia.

A mis compañeros de la maestría, que me acompañaron cada viernes en La Plata.

Y a mi familia y amigos que me dieron su apoyo. 


\section{ÍNDICE TEMÁTICO}

Apartado Contenido

RESUMEN

1. INTRODUCCIÓN

1.1 Planteo del problema

1.2 Fundamentos de la elección del tema

1.3 Área de estudio

$1.4 \quad$ Objetivos e hipótesis

1.4.1 Objetivo general

1.4.2 Objetivos particulares

1.4.3 Hipótesis

1.5 Antecedentes sobre la temática

1.6 Publicaciones relacionadas con la presente investigación

1.7 Marco teórico conceptual

2. METODOLOGÍA

2.1 Información antecedente

2.2 Caracterización del medio físico a escala regional y local

2.2.1 Descripción de la cuenca del Arroyo Langueyú

2.2.2 Análisis de la hidrodinámica subterránea

2.2.3 Caracterización de la hidroquímica subterránea

2.2.4 Evaluación de la calidad microbiológica

2.3 Caracterización del subsistema social

2.3.1 Entrevistas a informantes calificados

2.3.2 Realización de encuestas

2.3.3 Caracterización de los actores de la gestión del agua

2.3.4 Evaluación de las condiciones de explotación y uso del agua

2.4 Análisis sistémico de la problemática local y pautas de gestión sustentable

2.4.1 Elaboración y puesta en práctica de propuestas de educación ambiental

2.4.2 Establecimiento de indicadores de sustentabilidad ambiental

2.4.3 Generación de pautas para la gestión sustentable del recurso hídrico

3. SUBSISTEMA FÍSICO-NATURAL

3.1 Caracterización regional

3.1.1 Geología, geomorfología y suelos

3.1.2 Hidrología

3.2 Análisis hidrológico en el Barrio Cerro Los Leones

3.2.1 Balance hídrico del período de estudio

3.2.2 Red de medición y muestreo
Páginas

1

2

3

4

5

8

8

8

9

9

13

14

24

24

24

24

25

27

30

33

33

34

34

35

35

36

35

37

38

38

39

41

45

45

47 
3.2.3 Hidrodinámica subterránea 49

3.2.4 Estimación de la recarga mediante balance de cloruros 56

$\begin{array}{lll}3.2 .5 & \text { Hidroquímica subterránea } & 57\end{array}$

$\begin{array}{lll}\text { 3.2.6 Calidad microbiológica } & 67\end{array}$

4. SUBSISTEMA SOCIAL 71

4.1 Abastecimiento de agua potable y cloacas en la ciudad de Tandil 71

$\begin{array}{lll}4.2 & \text { Red de actores involucrados en la gestión del agua } & 73\end{array}$

4.3 Caracterización socioeconómica del Barrio Cerro Los Leones 77

$4.4 \quad$ Situación relativa a la salud $\quad 82$

4.5 Condiciones de explotación y uso del recurso hídrico 83

4.5.1 Características de las perforaciones de la red de medición y muestreo $\quad 89$

4.5.2 Fuentes de contaminación del agua subterránea 96

5. PAUTAS DE GESTIÓN SUSTENTABLE 98

5.1 Abordaje sistémico de la problemática local 98

5.2 Tareas de educación ambiental y transferencia 99

$\begin{array}{lll}5.3 & \text { Indicadores básicos de sustentabilidad } & 104\end{array}$

5.4 Estrategias de gestión sustentable del recurso hídrico 108

5.4.1 Planificación y control de la explotación y uso del agua 108

5.4.2 Educación ambiental, capacitación y transferencia 110

5.4.3 Diseño y construcción de las perforaciones de captación 110

5.4.4 Sistemas de distribución y almacenamiento de agua 112

$\begin{array}{lll}\text { 5.4.5 Desinfección y potabilización } & 112\end{array}$

5.4.6 Disposición y tratamiento de efluentes domiciliarios 115

6. CONCLUSIONES Y RECOMENDACIONES 117

7. REFERENCIAS 121

$\begin{array}{lll}7.1 & \text { Bibliografía } & 121\end{array}$

$\begin{array}{lll}7.2 & \text { Sitios de Internet } & 128\end{array}$

$\begin{array}{lll}7.3 & \text { Artículos periodísticos } & 128\end{array}$

$\begin{array}{ll}\text { ANEXOS } & 129\end{array}$

I Planilla de campo para el relevamiento hidrodinámico y la toma de 130 muestras.

II Planilla de encuesta realizada a los habitantes. 131

III Balance hídrico seriado (2005 - 2008) 134

IV Modelo de informe de análisis físico-químicos entregado. 136

V Modelo de informe de análisis microbiológicos entregado. 137 


\section{ÍNDICE DE TABLAS}

Tabla N $\mathrm{N}^{\circ}$ Contenido Páginas

$1 \quad$ Temperatura media anual de Tandil, 1949-1986. 41

2 Balance hídrico mensual 1900-2003. 42

3 Características físico-químicas de las aguas subterráneas en la 45

$4 \quad$ Balance hídrico para el período Septiembre 2007 a Septiembre 2008. 46

$5 \quad$ Ubicación de los sitios de medición. 48

6 Cotas topográficas de los sitios de medición. $\quad 49$

$7 \quad$ Profundidad del nivel freático a lo largo del período. 50

$8 \quad$ Niveles piezométricos medidos y análisis estadístico por perforación. $\quad 52$

9 Conductividad eléctrica $(\mu \mathrm{S} / \mathrm{cm})$ y salinidad $(\mathrm{mg} / \mathrm{l})$ y análisis 59 estadístico por censo.

10 Resultados físico-químicos (septiembre de 2007) y análisis 61 estadístico.

11 Parámetros químicos recomendados para agua potable por el CAA. 62

12 Resultados físico-químicos (diciembre de 2007) y análisis 63 estadístico.
Concentraciones de nitratos $(\mathrm{mg} / \mathrm{l})$ y análisis estadístico.

$\begin{array}{lll}13 & \text { Concentraciones de nitratos }(\mathrm{mg} / \mathrm{l}) \text { y análisis estadístico. } & 64 \\ 14 & \text { Parámetros microbiológicos recomendados para agua potable por el } & 67\end{array}$ CAA.

15 Resultados de los análisis bacteriológicos. 68

16 Barrios de la ciudad de Tandil con deficiencias de agua potable y 73 servicios sanitarios.

17 Actores involucrados en la gestión del agua en la ciudad de Tandil. $\quad 77$

18 Casos de diarreas y parasitosis durante 2007 y 2008.

19 Características de las perforaciones de la red de muestreo. 90

20 Indicadores PER para el área de estudio. 106 


\section{ÍNDICE DE FIGURAS}

Figura Contenido Páginas

$\mathrm{N}^{\circ}$

$1 \quad$ Ubicación geográfica del partido de Tandil. 5

2 Cuenca del Arroyo Langueyú, con la ubicación del Barrio Cerro Los 6 Leones.

3 Imagen satelital del Barrio Cerro Los Leones. $\quad 7$

4 Esquema del Barrio Cerro Los Leones.

5 Medición del nivel freático en perforación con bomba sumergida. 26

6 Medición del nivel freático en perforación con bombeador. 26

$7 \quad$ Sonda utilizada para la medición de niveles. 26

$8 \quad$ Toma de muestra para análisis químico. 28

9 Conductivímetro. 28

10 Medición de conductividad eléctrica en un sitio de muestreo. 28

11 Equipo de espectrometría de absorción atómica. 29

12 Determinación de bicarbonatos. 30

13 Determinación de cloruros. 30

14 Espectrómetro para la medición de sulfatos y nitratos. 30

15 Siembra en profundidad para la determinación de bacterias mesófilas. 32

16 Placas para recuento de UFC (mesófilos) 32

17 Tubos para determinación de coliformes totales 32

18 Siembra en tubos para determinación de coliformes totales 32

19 Aislamiento para determinación de E. coli 32

20 Siembra en superficie para determinar E. coli 32

21 Aislamiento para determinar P. aeruginosa 33

22 Placas para el análisis de P. aeruginosa. 33

23 Cuenca del Arroyo Langueyú y ejido urbano. 38

$24 \quad$ Balance hídrico 1900-2003. 42

25 Mapa equipotencial, Cuenca del A Langueyú (Marzo 2007). 44

26 Mapa de isoconductividades, Cuenca del A Langueyú (Marzo 2007). 44

27 Precipitaciones mensuales históricas y del período de estudio. 46

28 Balance hídrico para el período Septiembre 2007 a Septiembre 2008

29 Red de pozos de medición y muestreo. 48

$30 \quad$ Mapa de isoprofundidades del nivel freático para diciembre 2007.

$31 \quad$ Mapa de isoprofundidades del nivel freático para septiembre 2008. 51

$32 \quad$ Descenso de los niveles desde diciembre 2007 a septiembre 2008.

33 Mapa equipotencial de la zona de estudio, para septiembre de 2007.

$34 \quad$ Variación del nivel piezométrico en la perforación $\mathrm{N}^{\circ} 4$. 
36 Variación del nivel piezométrico en la perforación $\mathrm{N}^{\circ} 10$.

$37 \quad$ Variación del nivel piezométrico en la perforación $\mathrm{N}^{\circ} 15$.

38 Variación del nivel respecto a las precipitaciones en la perforación $\mathrm{N}^{\circ} 15 \quad 56$

39 Valores medios, máximos y mínimos de conductividad eléctrica en el 59 período.

$40 \quad$ Mapa de isoconductividades para septiembre de $2007 . \quad 60$

41 Diagrama de Schoeller para cinco muestras. 62

42 Diagrama de Piper para diez muestras. 62

43 Valores medios, máximos y mínimos de nitratos en el período. 65

$44 \quad$ Mapa de isoconcentraciones de nitratos para septiembre de 2007.

45 Distribución de los resultados bacteriológicos. 68

46 Recuento de mesófilos. 69

$47 \quad$ Muestra con altos niveles de coliformes totales.

$48 \quad$ Confirmación de E. coli 70

49 Formación de velo superficial en tubos para análisis de P. aeruginosa $\quad 70$

50 Determinación de P. aeruginosa 70

51 Cobertura de la red de agua potable 71

52 Cobertura de la red cloacal 71

53 Ciudad de Tandil y ubicación de los barrios periurbanos. 72

$54 \quad$ Ubicación de las viviendas encuestadas. 78

55 a 58 Viviendas del Barrio Cerro Los Leones 79

59 Sala de Atención Primaria a la Salud. 80

60 Bar El Cerro $\quad 80$

$61 \quad$ Centro Comunitario Zona $13 . \quad 80$

62 Acceso a la cantera abandonada Cerro Los Leones. 81

63 Cava de la cantera Los Leones. $\quad 81$

$64 \quad$ Fuentes de agua para bebida humano. $\quad 84$

$65 \quad$ Pozo compartido por dos viviendas. $\quad 85$

66 Antiguo jagüel con bombeador. 85

67 Presencia de cañerías de encamisado. $\quad 85$

68 Desinfección de pozos. $\quad 86$

69 Desinfección de tanques y cañerías. 86

$70 \quad$ Almacenamiento del agua. $\quad 86$

71 Sistemas de distribución de agua. $\quad 86$

$\begin{array}{lll}72 & \text { Cañerías de distribución del agua. } & 87\end{array}$

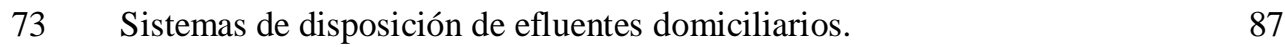

74 Baño tipo letrina. 
75 Pozo absorbente con evidencias de desmoronamiento. 88

76 Cobertura deficiente de un pozo absorbente. 88

77 Contaminación del agua subterránea por un pozo absorbente. 88

78 Distancias entre perforaciones y sitios de disposición de efluentes. 89

79 Perforación $\mathrm{N}^{\mathrm{o}} 1 \quad 90$

$80 \quad$ Perforación $\mathrm{N}^{\mathrm{o}} 2 \quad 91$

81 Perforación $\mathrm{N}^{\circ} 3 \quad 91$

82 Perforación $\mathrm{N}^{\circ} 4$

83 Perforación $\mathrm{N}^{\circ} 5$

$84 \quad$ Perforación $\mathrm{N}^{\circ} 6 \quad 92$

$85 \quad$ Perforación $\mathrm{N}^{\circ} 7 \quad 92$

86 Perforación $\mathrm{N}^{\mathrm{o}} 8 \quad 93$

$87 \quad$ Perforación $\mathrm{N}^{\mathrm{o}} 9 \quad 93$

$88 \quad$ Perforación $\mathrm{N}^{\circ} 10 \quad 93$

$89 \quad$ Perforación $\mathrm{N}^{\circ} 11$

$90 \quad$ Perforación $\mathrm{N}^{\circ} 12$

$91 \quad$ Perforación $\mathrm{N}^{\mathrm{o}} 13 \quad 94$

$92 \quad$ Perforación $\mathrm{N}^{\circ} 14 \quad 95$

93 Perforación $\mathrm{N}^{\circ} 15 \quad 95$

94 Perforación $\mathrm{N}^{\mathrm{o}} 16 \quad 95$

95 Perforación $\mathrm{N}^{\mathrm{o}} 17 \quad 96$

96 Perforación $\mathrm{N}^{\circ} 18 \quad 96$

97 Basural espontáneo en el Barrio. $\quad 97$

$98 \quad$ Horno ladrillero y cava de extracción de suelo. 97

99 Escuelas Primaria No 4 y Secundaria No 15.100

$100 \quad$ Jardín de Infantes $N^{\circ} 915 . \quad 100$

101 Taller con alumnos de 3er ciclo. 101

102 Taller con alumnos de 1er ciclo. 101

103 Taller con alumnos de 2do ciclo. 101

104 Taller con alumnos del Jardín de Infantes. 101

105 Adultos presentes en la charla-taller. 103 


\section{RESUMEN}

Se basa esta investigación en la evaluación ambiental de las condiciones de explotación y uso del recurso hídrico subterráneo en el Barrio Cerro Los Leones, ubicado al Oeste de la ciudad de Tandil, en el centro-SE de la provincia de Buenos Aires. El interés por dicho sector surgió a partir de las falencias en la provisión de agua potable y servicios sanitarios. El objetivo principal consistió en la generación de pautas de gestión sustentable basadas en el análisis y evaluación del sistema subterráneo, la calidad del recurso y sus modos de uso por parte de la población local. Se abordó el estudio desde una perspectiva sistémica de la problemática ambiental.

Se caracterizó el subsistema físico-natural de Tandil y en particular del Barrio Cerro Los Leones, principalmente el medio hídrico subterráneo. La hidrodinámica mostró un sentido local acorde al flujo regional, en dirección SW-NE. La caracterización de las aguas indicó que son de baja salinidad y, desde el punto de vista iónico, bicarbonatadas cálcico-magnésicas. Se detectaron concentraciones de nitratos y parámetros microbiológicos que superan los límites recomendados para consumo humano.

Se describió el subsistema social, especialmente los actores involucrados en el proceso de gestión así como las condiciones de explotación y uso del agua. Se evidenciaron deficiencias en las perforaciones y en los sistemas de distribución y almacenamiento. Asimismo, los efluentes domiciliarios son dispuestos en pozos absorbentes, ubicados a escasa distancia de las captaciones, lo que facilita la contaminación del recurso.

Ambos subsistemas fueron integrados, sentando las bases para elaborar guías de sustentabilidad en la gestión. Se produjeron indicadores útiles para la evaluación y monitoreo de la problemática local, así como para su aplicación en otros sectores con similares características. Se llevaron a cabo tareas de educación ambiental en ámbitos educativos formales y en la comunidad, permitiendo la comprensión de la problemática por parte de los habitantes y el conocimiento de las actitudes y acciones a tomar.

Considerando que la ecohidrología busca soluciones o alternativas ante problemáticas ambientales que involucran el agua y la población, fueron establecidas las mencionadas pautas para la gestión sustentable del recurso. Éstas incluyeron estrategias de planificación, evaluación y control sobre los modos de explotación y uso, tareas de capacitación y concientización de la población acerca de la problemática local. Además, medidas preventivas y de mitigación referidas a cuestiones estructurales sobre las perforaciones, los sistemas de distribución y almacenamiento de agua y la disposición y tratamiento adecuado de efluentes domiciliarios. 


\section{INTRODUCCIÓN}

La presente investigación es uno de los requisitos para la obtención del título de Magíster en Evaluación Ambiental de Sistemas Hidrológicos, otorgado por la Facultad de Ciencias Naturales y Museo y la Facultad de Ingeniería de la Universidad Nacional de La Plata.

El tema fue elegido por su destacado interés dentro de las ciencias ambientales en general y de la ecohidrología en particular. Se basó en el análisis y evaluación de los modos de explotación y uso del recurso hídrico subterráneo en un sector de la ciudad de Tandil.

El agua es una sustancia fundamental para la vida. Su aprovechamiento para las distintas actividades humanas y la modificación que éstas producen sobre el ciclo hidrológico, la convierten en un bien vulnerable de ser contaminado.

Es importante analizar las condiciones del uso, así como de su manejo, para comprender la situación del recurso en la actualidad y las necesidades de nuevas estrategias, tendiendo a su preservación y gestión sostenible. Con respecto al acceso por parte de la población, no sólo es importante su disponibilidad, sino también su aptitud para el consumo.

La comprensión del ambiente, de su estructura biofísica y socioeconómica, así como su funcionamiento y dinámica, es fundamental para avanzar en el proceso de desarrollo sustentable a escala local y regional. La complejidad ambiental genera la necesidad de un abordaje del agua que considere la integración de conocimientos aportados por las ciencias naturales y sociales. Por ello, la gestión y planificación del uso de este recurso debe realizarse con una visión global, considerando las características propias del área de estudio así como las condiciones de explotación mediante las cuales la población accede al mismo.

El desarrollo de la Tesis se organiza en seis capítulos. El Capítulo I, la Introducción, incluye la descripción del problema, los fundamentos de su elección, la ubicación y descripción del área de estudio, los objetivos que se persiguen, la hipótesis de base, así como los antecedentes más relevantes y los conceptos teóricos fundamentales.

La metodología aplicada para el desarrollo de la investigación, específicamente los materiales y métodos utilizados, se detalla en el Capítulo II.

La caracterización del subsistema físico-natural a escalas regional y local se realiza

en el Capítulo III. Éste comprende la descripción de la hidrodinámica e hidroquímica 
subterránea, así como la evaluación de la calidad del agua para consumo humano, según parámetros químicos y microbiológicos.

Por su parte, el Capítulo IV aborda la caracterización del subsistema social, tanto a nivel de la ciudad de Tandil como del barrio en estudio. Incluye el análisis de la red de actores involucrados en la problemática, así como la descripción de las condiciones de explotación y uso del recurso hídrico a escala local.

A partir del diagnóstico realizado, el Capítulo $\mathrm{V}$ se ocupa del análisis y abordaje sistémico de la problemática hídrica bajo estudio, a partir de la integración de los subsistemas social y natural antes evaluados. Describe las pautas de educación ambiental llevadas a cabo a lo largo del trabajo, así como propone estrategias de gestión e indicadores de sustentabilidad del recurso hídrico, útiles para evaluar la evolución de la problemática en el tiempo, y compararla con las existentes en otras áreas de estudio.

Para finalizar, el Capítulo VI presenta las principales conclusiones de la investigación, y establece recomendaciones surgidas del trabajo, útiles para los tomadores de decisiones y la población involucrada.

\subsection{Planteo del problema}

En la ciudad de Tandil, que cuenta con 108.086 habitantes (INDEC, 2002), el Municipio provee los servicios de agua potable y cloacas, por medio del ente Obras Sanitarias Tandil, sin embargo ambas redes no cubren la totalidad de la ciudad (AYDET FCH-UNCPBA, 2004), por lo cual la población no abastecida posee otros modos de explotación, uso y disposición del agua residual.

A partir de la evaluación a nivel general de la ciudad de Tandil, y el análisis de los sectores urbanos sin cobertura de servicios sanitarios, se ha seleccionado el Barrio Cerro Los Leones como área de estudio.

Su elección se debió a un conjunto de factores, entre ellos: la ausencia de ambos servicios, antecedentes de contaminación microbiológica en muestras de agua tomadas a partir de las perforaciones de diferentes viviendas e instituciones (Dirección de Bromatología del Municipio de Tandil), bajo nivel socioeconómico de la mayor parte de la población y detección de enfermedades relacionadas al recurso hídrico en la Sala de Atención Primaria a la Salud, sobre todo parasitosis. A todo ello se agregan problemáticas asociadas a los pozos absorbentes y además la presencia de actividades que pueden tener efectos adversos sobre la calidad del agua, tales como depósitos de residuos sólidos domiciliarios e industriales, criaderos de animales y hornos ladrilleros entre otros. 
La situación del barrio, da lugar a condiciones ambientales particulares en relación al uso del recurso hídrico subterráneo. En primer lugar, los habitantes poseen sus perforaciones para acceder y explotar el acuífero freático, las cuales en muchos casos son realizadas por ellos mismos. La mayoría, carece del diseño que garantice la protección del acuífero y la vida útil de la obra, por lo cual suceden desmoronamientos y agotamientos de pozos. Normalmente esta falta de diseño adecuado, de protección sanitaria de las perforaciones, y de distanciamiento entre éstas y los pozos absorbentes, hace que se produzca la contaminación del acuífero. A todo esto se suma la disposición in situ de otras cargas como residuos sólidos urbanos e industriales en cavas abandonadas, que agravan la situación, potenciando el riesgo.

Por otro lado, los habitantes disponen sus efluentes domiciliarios en pozos absorbentes, también llamados pozos ciegos, realizados in situ. Se repite el inconveniente de falta de diseño y planificación, generando así un foco contaminante dispuesto normalmente a escasa distancia de la perforación de bombeo. A través del flujo subterráneo se produce la interconexión y la degradación de la calidad del agua de bebida, tanto en forma físico-química como bacteriológica (Custodio y Llamas, 1976). Además, se suman otros inconvenientes, como la frecuente colmatación, derrumbes por las debilidades en su construcción, problemas en el tapado y sellado, cercanía entre perforaciones y sitios de disposición de efluentes de viviendas vecinas, entre otros.

Esta situación no es fácilmente reversible, pues los pobladores no tienen otra opción a la hora de abastecerse de agua para consumo y su disposición. De este modo, la calidad del agua subterránea se ve deteriorada por la falta de servicios sumándose la posible presencia de otros focos contaminantes, lo que afecta directamente a la población, que

piensa en muchos casos que el agua es de buena calidad sólo debido a su aspecto claro y transparente. Uno de los posibles efectos de este deterioro es sobre la salud humana, a través de enfermedades de origen hídrico.

\subsection{Fundamentos de la elección del tema}

Ante la problemática ambiental planteada, es de utilidad la realización de una investigación como la que aquí se propone, donde se analiza y evalúa de manera integral la dinámica del sistema ambiental, basada en los pilares de equidad social, desarrollo económico y preservación y protección de los recursos naturales, vinculada a la gestión sustentable del agua.

El tema elegido es de interés tanto en el campo de la ecohidrología así como en el de las ciencias ambientales en general. 
En particular se procurará:

- Proveer información actualizada sobre las características del agua subterránea, su modo de explotación y uso, constituyendo un aporte para el conocimiento de las condiciones sanitarias de la población y el mejoramiento de su calidad de vida.

- Generar información sobre los recursos hídricos locales, posible de transferir a la comunidad, y a los grupos en riesgo en particular, a través de instancias de educación ambiental en el ámbito formal y no formal.

- Construir indicadores de sustentabilidad que contribuyan a la elaboración de estrategias de gestión ambiental y al uso racional del agua.

En un contexto en el que Tandil basa el desarrollo local en la premisa de sustentabilidad ambiental, la realización de investigaciones como la aquí planteada, constituye un insumo fundamental para alcanzar el proyecto deseado de ciudad.

Como propósito a futuro, esta propuesta permitirá comprender el proceso de gestión local del agua subterránea en un barrio de Tandil y compararlo con el existente en otros lugares, a través de la construcción de un sistema de indicadores ambientales de evaluación de las condiciones de explotación y uso.

\section{3. Área de estudio}

Esta investigación se ha realizado en el Barrio Cerro Los Leones ubicado al Oeste de la ciudad de Tandil, a unos $6 \mathrm{~km}$ del centro de la misma, y dentro del partido homónimo, en la provincia de Buenos Aires, Argentina (Figura 1).

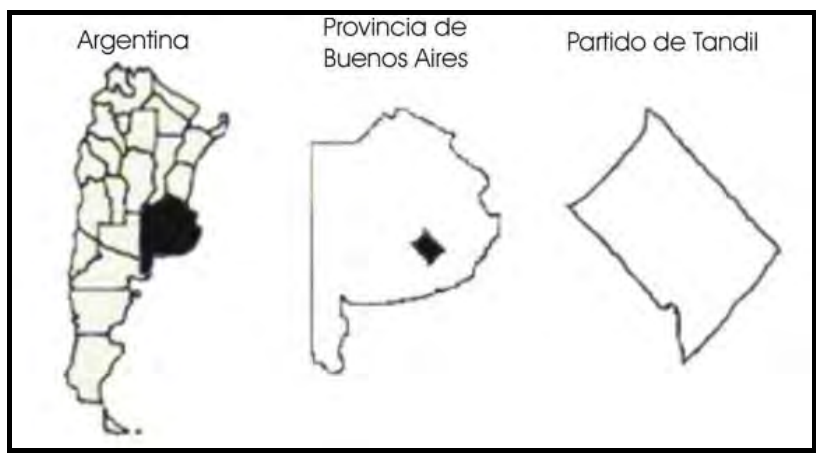

Figura 1. Ubicación geográfica del partido de Tandil.

El área de estudio se asienta en la cuenca del arroyo Langueyú, desarrollada sobre el faldeo Norte de las sierras de Tandil, también denominadas Sierras Septentrionales de la Provincia de Buenos Aires, que ocupan la región centro - sudeste de dicha provincia, orientadas en sentido NO-SE. Las mayores alturas de encuentran al sur de la cuenca, alcanzando los $500 \mathrm{msnm}$, descendiendo hacia el NE. 
Esta cuenca drena sus aguas hacia el NE en concordancia con la pendiente regional (Ruiz de Galarreta, et al., 2007). En la cuenca alta del arroyo Langueyú se localiza la ciudad de Tandil situada a unos 220 metros de altura sobre el nivel del mar (Figura 2). Los cerros que la limitan y rodean poseen alturas que varían entre los 300 y 500 msnm.

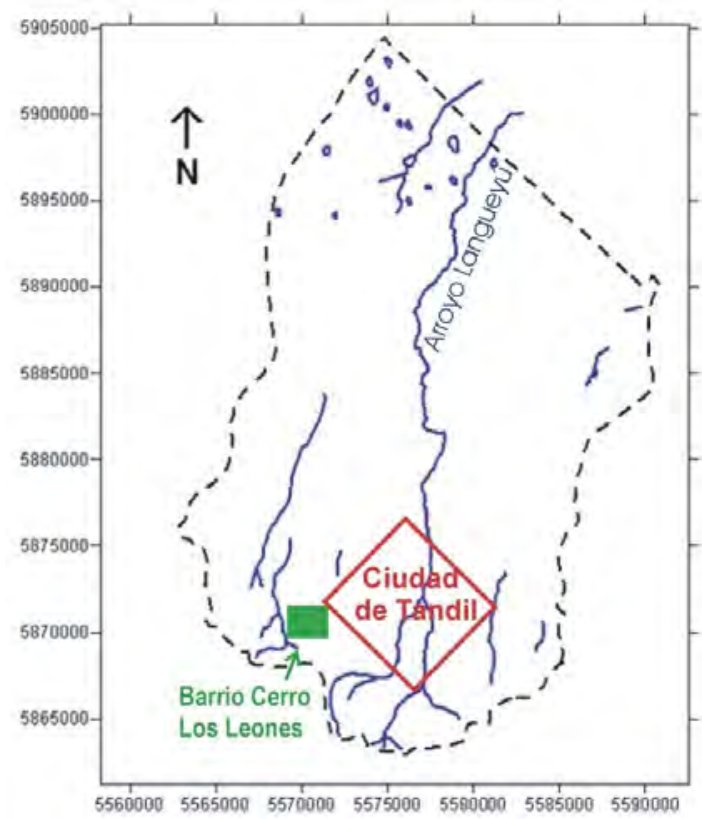

Figura 2. Cuenca del Arroyo Langueyú, con la ubicación del Barrio Cerro Los Leones.

El paraje lleva el nombre del cerro lindero, en el cual se ha realizado históricamente minería, dando origen al poblamiento del barrio. Dada la intensa extracción minera precedente, el cerro morfológicamente ha desaparecido (Figura 3), y actualmente la cantera se encuentra fuera de explotación (Fontana, 1947; Gorraiz Beloqui, 1958). 


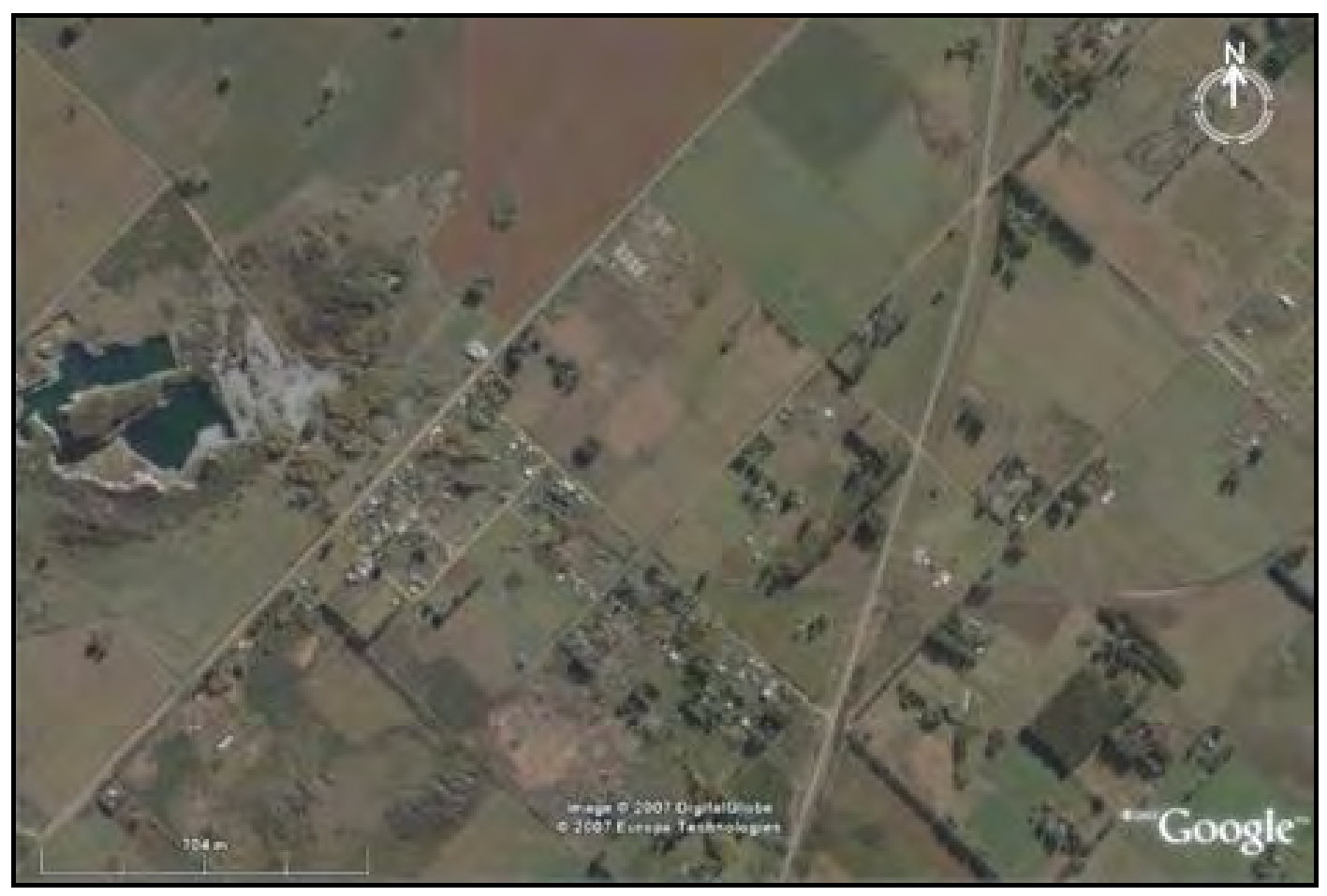

Figura 3. Imagen satelital del Barrio Cerro Los Leones.

La principal concentración de población está ubicada en la zona comprendida entre las Calles Galicia, G. Cima, Avenida Basso Aguirre y la Ruta Provincial No 30 (Figura 4). En los alrededores de dicha área, la densidad de viviendas es menor. Actualmente, se observa un poblamiento gradual, especialmente hacia el NE, sobre la Calle Chaperouge.

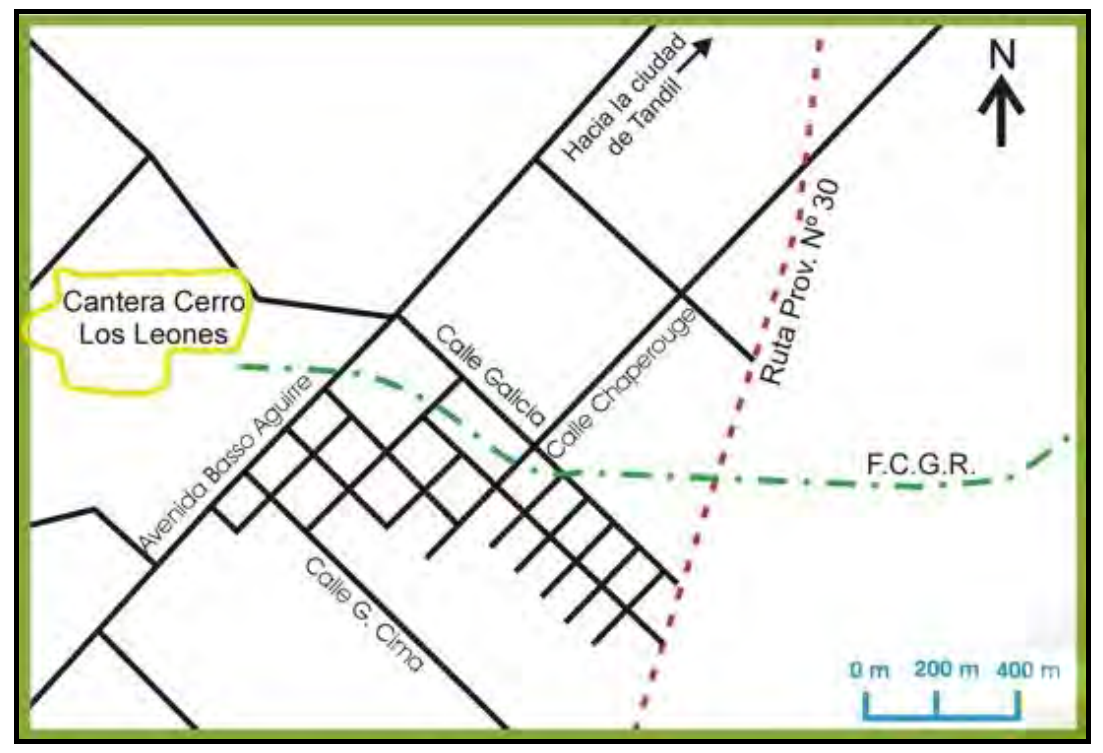

Figura 4. Esquema del Barrio Cerro Los Leones. 
Este barrio está constituido por un pequeño conjunto de viviendas de familias de clase media y baja, que totalizan alrededor de 300 habitantes. Se observaron diferentes deficiencias en la mayoría de las viviendas, además de la falta de servicios de agua y cloacas, tales como: la ausencia de red de gas natural y desagües pluviales, el uso precario de maderas, chapas y otros elementos como materiales de construcción, la presencia de baños tipo letrina ubicados fuera de las viviendas, el abastecimiento de agua a través de una única canilla (ubicada en el domicilio), con el consecuente acarreo de agua.

El paraje se encontró densamente poblado en la época del auge de la actividad minera, entre 1900 y 1930, siendo la cantera Cerro Leones una de las principales, por la calidad y cantidad de la roca granítica presente, así como por su facilidad de explotación. El número de obreros canteristas en la ciudad alcanzó a 3000 en 1913, de los cuales 1000 residían en este barrio (Nario, 1982). Tras esta época de auge, el barrio sufrió un despoblamiento masivo, quedando en la actualidad algunas viviendas típicas de la época, construidas especialmente con chapas y maderas. Por otro lado, según testimonios de los pobladores, existen numerosos pozos absorbentes abandonados realizados por los antiguos habitantes, de los que se desconoce su ubicación.

\subsection{Objetivos e hipótesis}

\subsubsection{Objetivo general}

Generar pautas de gestión sustentable, a partir del análisis y evaluación de las condiciones de explotación y uso del recurso hídrico subterráneo en el Barrio Cerro Los Leones, de la localidad de Tandil.

\subsubsection{Objetivos particulares}

- Caracterizar el subsistema físico-natural de Tandil, en particular el Barrio Cerro Los Leones, principalmente el sistema hídrico subterráneo (dinámica y cualidades fisicoquímicas y bacteriológicas).

- Describir el subsistema socioeconómico, analizando las condiciones de acceso y utilización del agua por parte de los habitantes del barrio seleccionado.

- Evaluar sistémicamente la problemática hídrica local, a partir de la integración de los subsistemas socioeconómico y físico-natural, abordando las interrelaciones del recurso con las dimensiones social, económica y político-institucional. 
- Establecer indicadores de sustentabilidad ambiental en relación a la gestión del agua y las condiciones de vida de la población.

- Generar estrategias de educación ambiental y pautas para la gestión sustentable del recurso a escala local.

\subsubsection{Hipótesis}

La falta de planificación y gestión sustentable del recurso hídrico subterráneo en el barrio Cerro Los Leones, en especial debida a la ausencia de saneamiento básico, genera la contaminación química y bacteriológica del mismo, poniendo en riesgo la salud y afectando la calidad de vida de los habitantes.

\subsection{Antecedentes sobre la temática}

Existen diferentes antecedentes a nivel local que dan cuenta de la problemática ambiental relacionada al agua. En ellos se pone de manifiesto la necesidad de investigar en forma integral su gestión, debido a la importancia que posee el agua para la salud humana y la calidad de vida de la población. Asimismo, esta información antecedente plantea la necesidad de reconstruir el juego de actores que interviene en la gestión del recurso hídrico a escala local, y considerar las modalidades de explotación y consumo para diferentes usos.

Respecto al análisis y caracterización del medio físico en Tandilia, existen numerosos trabajos antecedentes sobre los aspectos geológicos, geomorfológicos e hidrológicos a escala regional, como los de Teruggi y Kilmurray (1975 y 1980), Fidalgo et al. (1975), Rabassa (1973), Sala (1975), Hernández et al. (1975), Gentile (1995), Dalla Salda (1999), Dalla Salda et al. (2005), Iñiguez Rodriguez (1999), Poiré et al. (2005). Por su parte, González (2005) ha caracterizado los ambientes hidrogeológicos de la provincia de Buenos Aires, incluyendo la descripción para la región serrana de Tandilia. También a escala regional, Hernández (2005) describe la situación ambiental de los recursos hídricos subterráneos en la provincia, indicando el panorama para la zona de Tandilia. Hernández et al. (2002) determinaron la línea de base ambiental para las aguas superficiales y subterráneas en la zona minera de Tandilia, incluyendo la detección de elementos mayoritarios e indicadores considerados como representativos de las condiciones ambientales.

Particularmente para el partido de Tandil, se cuenta con trabajos específicos sobre geohidrología como los de Simini y Rivas Roche (1980) y Sala et al. (1981). El Director de este proyecto ha generado investigaciones en el partido, especialmente en la cuenca 
superior del Arroyo Tandileofú en el período 1983-1990 y la aplicación de un modelo hidrológico calibrado para el período 1986-1989 y su validación en el lapso 2001-2003 (Ruiz de Galarreta, 2006).

En el ámbito de la cuenca del Arroyo Langueyú sobre la que se asienta la ciudad de Tandil, el grupo de trabajo del Centro de Investigaciones y Estudios Ambientales (CINEA), perteneciente a la Facultad de Ciencias Humanas de la Universidad Nacional del Centro de la Provincia de Buenos Aires, ha investigado sobre sus características geohidrológicas, haciendo hincapié en su hidrodinámica e hidroquímica, tal como lo presenta Ruiz de Galarreta et al. (2007) y Barranquero et al. (2008a, 2008b, y 2009). Asimismo, se han desarrollado investigaciones sobre la interrelación entre actividades humanas y el medio físico-natural, especialmente analizando las fuentes de contaminación del recurso hídrico superficial y subterráneo en dicha cuenca, habiéndose determinado las principales cargas contaminantes que lo afectan. (Banda Noriega et al., 2008). El Parque Industrial de Tandil constituye un ejemplo donde se evaluaron previamente las cargas contaminantes de la actividad industrial así como la vulnerabilidad del acuífero. (Ruiz de Galarreta et al., 2004).

Además, en el CINEA se han realizado diferentes trabajos con organismos e instituciones locales. Uno de ellos fue la investigación y evaluación conjunta con Obras Sanitarias de Tandil (OST) sobre las concentraciones de nitratos en aguas subterráneas. Asimismo, estudios como los de Ruiz de Galarreta y Banda Noriega (2005) y Barranquero et al. (2006), han demostrado la presencia de elevados niveles de nitratos en las perforaciones más antiguas de dicho ente. Asimismo se ha comprobado la existencia de altas concentraciones de este ión en pozos domiciliarios fuera del área abastecida por la red municipal. Estos estudios poseen una importancia clave en la determinación de la calidad de agua de bebida de la que disponen los habitantes de Tandil, dando las bases para nuevas estrategias por parte del gobierno local y OST tendientes a una mejora en el servicio de agua potable, y calidad de vida.

En el CINEA junto con la Comisión de Lucha contra plagas agrícolas de Tandil, organismo relacionado con el Instituto Nacional de Tecnología Agropecuaria (INTA) y con la Sociedad Rural de Tandil, se trabajó en un diagnóstico de las características hidroquímicas del agua subterránea a nivel de reconocimiento en el Partido de Tandil a fin de evaluar la concentración de nitratos y agroquímicos, principalmente aquellos más comúnmente utilizados en la zona. Este diagnóstico brinda un punto de partida para estudios y para las gestiones en lo relacionado al manejo del recurso en el ámbito urbano y rural.

Existen datos sobre las aguas subterráneas provenientes de los pozos de explotación de Obras Sanitarias Tandil (OST), particularmente las concentraciones de nitratos en las 
mismas. Los resultados obtenidos indican la presencia de tenores superiores al nivel máximo permisible fijado por el Código Alimentario Argentino (Barranquero et al., 2006).

Por su parte, Marzoratti (2004) investigó sobre las características hidrodinámicas y la calidad del agua subterránea en el Barrio Golf, ubicado en la periferia SE de la ciudad de Tandil. El autor abordó la posible relación entre la ausencia de servicios sanitarios y la calidad del recurso utilizado para consumo, a través de la medición de nitratos y conductividad eléctrica. Se detectaron zonas con mayores concentraciones de nitratos, incluso superiores a lo establecido en la legislación argentina, coincidiendo con áreas de mayor densidad poblacional y antigüedad de viviendas.

García et al. (2006) y García y Martín (2007) relacionaron las características sociales de la población de la ciudad de Tandil con las concentraciones de nitratos en aguas superficiales y subterráneas, a través de la utilización de un Sistema de Información Geográfica (SIG). La integración permitió determinar áreas de riesgo, según las condiciones de vida y los grupos etarios. En numerosos casos, las concentraciones de nitratos exceden los límites recomendados, incluso en muestras provenientes de la red de abastecimiento público.

Otro estudio previo sobre el recurso hídrico subterráneo del partido de Tandil fue llevado a cado por la Dirección de Bromatología, Laboratorio Zonal de Salud Pública, Municipalidad de Tandil, donde se caracterizaron las aguas tanto química como microbiológicamente (Gallo et al., 2004). Los resultados de este trabajo indican la existencia de contaminación bacteriológica de aguas en distintos puntos del área, así como la presencia de niveles de nitratos superiores a $45 \mathrm{ppm}$. Se observa que son determinantes las características que hacen al diseño de la perforación. Además existen antecedentes de análisis de aguas realizados por la Dirección de Bromatología local, de distintos sectores de Tandil.

Por otra parte, un estudio a nivel local, en el que participó la Licenciada Rodríguez, consistió en el análisis de la problemática hídrica en un barrio del sur de la ciudad de Tandil, ubicado sobre la Avenida Don Bosco, el cual se encuentra en constante crecimiento. Penone et al. (2009) evaluaron las características hidrodinámicas e hidroquímicas en la zona, considerando la importancia y los efectos de las actividades humanas llevadas a cabo.

En la dimensión social, se han analizado las condiciones de explotación del agua a nivel de la ciudad de Tandil, incluyendo la generación y disposición de efluentes domiciliarios, los cuales constituyen una de las principales cargas contaminantes introducidas al sistema subterráneo (Banda Noriega et al., 2008). 
García (2008) analizó las relaciones entre la calidad de vida urbana en Tandil y la calidad del agua potencialmente afectada por la actividad industrial, con el objetivo de determinar la vulnerabilidad social hacia el riesgo de contaminación de tal origen.

En lo referido al actual manejo del recurso hídrico, se analizaron los antecedentes sobre los servicios de agua potable y cloacas en la ciudad de Tandil. Una referencia muy importante la brinda el Plan de Ordenamiento Territorial del Municipio de Tandil (AYDET y FCH-UNCPBA, 2004), que indica las coberturas de ambos servicios y los problemas de deficiencia de los mismos sobre el área periurbana.

Uno los barrios periféricos de la ciudad de Tandil, con mayores problemas relacionados al agua de consumo, es el Barrio Cerro Los Leones en el que se basa esta investigación y sobre el cual han sido publicados artículos periodísticos. Por una lado, la Revista "La educación en nuestras manos" (Martinelli, 2004), dio a conocer el trabajo realizado por los alumnos y profesores de 6to grado, acerca de la calidad del agua que consumía el establecimiento, con el objetivo de determinar la potabilidad de la misma y conocer los posibles factores de contaminación. Para ello, se analizó bacteriológicamente una muestra de agua de la perforación de la Escuela de Cerro Leones, donde se obtuvo un resultado de bacterias coliformes superior al establecido por el Código Alimentario Argentino. Los alumnos concluyeron en que el agua del establecimiento educativo, la cual consumen a diario en el comedor, no es microbiológicamente apta. La experiencia fue premiada en la Feria de Ciencias local por el alto impacto comunitario, y luego fue dada a conocer en la Feria de Ciencias regional.

Numerosos artículos periodísticos sobre la calidad del recurso en Tandil, han sido publicados en los diarios locales, así como en los portales digitales. En particular, en el Diario Nueva Era (28/08/2004) la nota titulada "Consumir agua en Cerro Leones, enferma" comenta el trabajo realizado por los alumnos de la escuela de Cerro Leones. El periódico destaca que el resultado del trabajo ha sido que "es riesgoso para la salud consumir el agua de dicho paraje". Según el artículo, existe relación entre algunas de las enfermedades que se presentan a diario en los vecinos de barrio, y la calidad de agua de ingesta.

Estos artículos manifiestan la preocupación creciente observada en los últimos años, aunque no ha sido acompañada por un abordaje integral, destacándose la necesidad de producir conocimientos objetivos y con bases científicas para lograr la sustentabilidad ambiental en la gestión a nivel local.

Se han encontrado estudios similares, como el caso de un grupo de estudiantes, docentes y graduados de la Facultad de Ciencias Exactas y Naturales (FCEyN) de la 
Universidad de Buenos Aires, que durante los años 2002 y 2003, llevaron adelante el relevamiento de la calidad del agua subterránea en barrios del Gran Buenos Aires, en particular en el Barrio María Elena (Partido de La Matanza), donde realizaron análisis microbiológicos, para determinar el grado de contaminación.

En relación a los antecedentes de gestión, el objetivo de la generación de indicadores es conocer el estado actual del recurso y su evolución en el tiempo. Algunos antecedentes sobre la temática incluyen a Blarasin et al. (2002), Allen (1996) y Di Pace (2001). Específicamente en el campo de la geohidrología, Berger y Iams (1996), establecen geoindicadores para las aguas subterráneas, destacando su importancia para el estudio de los cambios hidrogeológicos y el monitoreo y gestión ambiental. Othax (2004) ofrece una propuesta de indicadores de sostenibilidad ambiental urbana para evaluar la gestión del agua de red en la ciudad de Rauch, provincia de Buenos Aires. Asimismo, Bertoni (2009) y Bukosky (2008) plantean una serie de indicadores para la gestión del servicio de agua potable en las localidades de Coronel Dorrego y Oriente, respectivamente. El director de esta investigación ha participado en la generación, para ocho municipios bonaerenses, de una batería de indicadores útiles para el seguimiento temporal de diferentes áreas temáticas, entre ellas el agua (Guerrero et al., 2007).

Otro antecedente relevante en relación a la elaboración de indicadores ambientales, lo constituye el Modelo de indicadores de Presión-Estado-Respuesta, establecido por la Organización para la Cooperación y el Desarrollo Económico (OCDE, 1993). Dicho modelo considera que las actividades humanas ejercen Presión sobre el ambiente y los recursos naturales, afectando su calidad y cantidad respectivamente, generando un Estado como resultado. La sociedad ofrece Respuestas a éstos cambios a través de políticas ambientales sectoriales y económicas generales y a través cambios en su comportamiento y conciencia hacia el medio ambiente.

\subsection{Publicaciones relacionadas con la presente investigación}

A lo largo del desarrollo de la presente tesis, se han publicado o se encuentran en prensa, resultados parciales de la investigación, como se detalla a continuación:

- Educación y transferencia para la gestión del agua: casos de Tandil.

Rodriguez, C. I.; Díaz, A.; Banda Noriega, R.; Ruiz de Galarreta, A.

Congreso de Ciencias Ambientales COPIME 2009. Artículo completo en CD ROM. Resumen en Actas. p. 58.

Ponencia distinguida con el Segundo Premio en el Eje "Comunidad, Participación y Educación Ambiental".

Ciudad Autónoma de Buenos Aires. Octubre de 2009. 
- Condiciones de explotación y uso doméstico del agua: el caso de un barrio periférico de la ciudad de Tandil, Buenos Aires, Argentina.

Rodríguez, C. I., Ruiz de Galarreta, V. A., Tabera, A.

Cuadernos del CURIHAM. ISSN 1514-2906. Vol. 14: 51-58.

Rosario, Santa Fe, Argentina. 2008.

- Hidrodinámica e hidroquímica subterránea en la zona del barrio Cerro Los Leones, Tandil, Buenos Aires.

Rodríguez, C. I.; Ruiz de Galarreta, A.; Quiroga, M. A.; Landa, R.

II Congreso Internacional sobre gestión y tratamiento integral del agua.

Trabajo completo en CD Libro ISBN 978-987-1253-44-9. p. 572-581.

Córdoba. Noviembre de 2008.

- Caracterización de cargas contaminantes generadas en Tandil y su implicancia en el recurso hídrico. Buenos Aires, Argentina.

Banda Noriega, R; Ruiz de Galarreta, A; Barranquero, R; Díaz, A; Miguel, E; y Rodríguez, C. I.

II Congreso Internacional sobre gestión y tratamiento integral del agua.

Trabajo completo en CD Libro ISBN 978-987-1253-44-9. p. 451- 463.

Córdoba. Noviembre de 2008.

- La educación ambiental como una estrategia de gestión integral del agua.

Rodriguez, C. I. y Ruiz de Galarreta, A.

IV Congreso Iberoamericano de Ambiente y Calidad de Vida.

Resumen publicado en Actas: El reto del desarrollo sostenible. Estrategias y acciones. Diálogos y propuestas. ISBN 978-950-746-167-5. p. 120-121.

Catamarca. Septiembre de 2008.

\subsection{Marco teórico conceptual}

La ecohidrología es una ciencia que busca soluciones o alternativas ante problemáticas que involucran a los recursos hídricos, la población y el ambiente. Uno de los conceptos fundamentales para esta ciencia es la disponibilidad de agua potable, basado en el funcionamiento del ciclo hidrológico, sus efectos sobre procesos ecológicos y el bienestar humano, a escala de cuenca. (Zalewski et al., 1997).

La ecohidrología propone una regulación dual del sistema ambiental, a través de la utilización de procesos ecológicos e hidrológicos para mejorar y mantener la integridad del ambiente frente a las alteraciones humanas. Con respecto al manejo sustentable de los 
recursos hídricos, provee, a los tomadores de decisiones y a la sociedad, una forma de trabajar hacia ese objetivo, realzando la capacidad de los ecosistemas para absorber los impactos adversos.

El concepto de desarrollo sustentable surge en 1987, cuando la Comisión de las Naciones Unidas sobre Medio Ambiente y Desarrollo presentó el estudio "Nuestro Futuro Común", conocido como Informe Brundtland. En el informe se establece que el Desarrollo Sostenible implica satisfacer las necesidades de las generaciones presentes sin comprometer el derecho de las generaciones futuras de satisfacer sus propias necesidades (WCED, 1987).

La sustentabilidad debe analizarse desde una perspectiva sistémica. La búsqueda del desarrollo sustentable o sostenible exige integrar factores económicos, sociales, culturales, políticos y ecológicos (Gallopin, 2003). Para ello se deben considerar los aspectos locales y globales, así como sus interrelaciones, del mismo modo que se requiere la ampliación del horizonte espacial y temporal, para tender hacia la equidad intra e intergeneracional.

Las problemáticas ambientales cubren un amplio espectro de situaciones, en las que están involucrados el medio físico-natural, la producción, la tecnología, la organización social, la economía, entre otros factores. En esas situaciones confluyen múltiples procesos cuyas interrelaciones constituyen la estructura de un sistema que funciona como una totalidad organizada, al cual García (1994) denomina sistema complejo. Éste requiere un abordaje integral, a través de una metodología interdisciplinaria, útil para analizar los procesos que tienen lugar en el sistema complejo y que explican su comportamiento y evolución.

El ambiente se construye a partir de la interrelación entre la sociedad y la naturaleza (Fernández, 1998). Esa totalidad se compone de tres subsistemas: social, económico y ecológico. La búsqueda del desarrollo sustentable debe tender al equilibrio entre esos subsistemas, de modo tal de lograr el bienestar social, el desarrollo económico y la integridad ecológica (Allen, 1996).

En el análisis de cada subsistema, es sustancial la identificación de los actores y los procesos, así como de las relaciones que construyen la dinámica ambiental a diferentes escalas. El rol del gobierno es primordial, debido a que debe generar y concretar políticas tendientes a la gestión ambiental asegurando la equidad en el acceso a los recursos y a su conservación.

Es importante la participación social en la búsqueda y puesta en práctica de estrategias tendientes a la sustentabilidad, respecto al manejo del agua. El concepto de 
gestión social se refiere al "proceso completo de acciones y toma de decisiones recorridas desde el abordaje de un problema, su estudio y comprensión, hasta el diseño y operación de propuestas en la realidad. Implica un aprendizaje conjunto y continuo para los grupos sociales, que les permite incidir en los procesos de la toma de decisiones dentro de la dimensión política" (ITESO, 2001).

En relación al uso del agua, ésta constituye la base para el desarrollo vital en todos los ecosistemas. Los cambios locales en el ciclo hidrológico introducidos por el hombre en determinados territorios, producen importantes transformaciones en el sistema ambiental. Mantener un seguimiento constante de las fuentes, la cantidad y la calidad del agua, así como las actividades antrópicas que lo afectan, es el punto de partida para lograr el desarrollo sustentable (Conferencia de las Naciones Unidas sobre el Medio Ambiente y el Desarrollo, 1992).

Los procesos de explotación y uso del agua subterránea, requieren la participación de personas, que se involucran de forma voluntaria o involuntaria, denominados "actores del proceso de gestión" por Dourejeanni (2000). El grado de participación de cada uno de ellos es variable. Pueden ser decisivos para dirigir los procesos, participantes activos o pasivos, poseedores de muchos o pocos recursos, actuar solos o agrupados, tener o no respaldo de gente o instituciones e intervenir desde el interior o exterior del ámbito. Además, pueden tener distinto interés en participar en la toma de decisiones así como en la realización de prácticas tendientes a la sustentabilidad del recurso hídrico.

Asimismo, Dourejeanni (2002) plantea una tipología de actores útil para mejorar el manejo de cuencas según cuatro variables principales. La primera es el nivel de gestión que los actores realizan en área, referido a su pertenencia. Se consideran cuatro niveles, los que deben estar articulados para que sea efectiva. Estos son el nivel científicoambiental, formado por grupos $\mathrm{u}$ organismos estatales o privados dedicados a su investigación; el económico-productivo: usuarios individuales, representados por empresas, habitantes, actividades industriales, agropecuarias, $u$ otras formas de organización que generalmente actúan en forma individual al intervenir en los sistemas hídricos compartidos; el normativo y de control que debe orientar y controlar los procesos de gestión para el manejo integral del agua; y el político-social, que debe ser conducido por consejos, comisiones o comités de cuencas, lo que tienen la responsabilidad de orientar las políticas de aprovechamiento del agua en función de los planes nacionales o regionales de desarrollo. La segunda variable a tener en cuenta es el carácter formal o informal, referido a la situación legal con que actúan en la cuenca o sector, relacionado al carácter legal del otorgamiento de derechos de uso de los recursos naturales, en particular del agua. En tercer lugar, el autor propone el carácter endógeno o exógeno del actor con relación al lugar donde habita y toma decisiones que afectan la dinámica del área y el uso del agua. Y por último, el carácter público o privado. 
Los sistemas de abastecimiento y distribución de agua en las viviendas, el acceso a la información necesaria para su adecuado manejo y consumo, y las políticas relativas a la gestión del agua, conllevan a la generación de determinadas condiciones de explotación y uso del recurso hídrico, en muchos casos signados por las deficiencias sanitarias y la disminución de la calidad del mismo para consumo humano.

Analizando los conceptos teóricos fundamentales dentro del medio físico natural, cabe comenzar por el ciclo hidrológico. Es la permanente transferencia de agua de unos puntos de almacenamiento a otros, con cambios en sus estados físicos y en su composición química y biológica, movilizado por la energía solar y la acción gravitacional. Constituye un sistema por el cual el agua se transporta conservando su volumen. Por un lado, las variaciones de la temperatura son responsables de la ocurrencia de fenómenos como evaporación, condensación y congelamiento del agua. Mientras que la gravedad terrestre es la fuerza que ocasiona la precipitación, produce la infiltración y hace fluir las aguas superficiales y subterráneas. Este ciclo incluye tres arcos: oceánico, atmosférico y terrestre, donde este último se integra a su vez por la fase superficial y la subterránea, estrechamente relacionadas.

La hidrología subterránea o hidrogeología es aquella parte de la hidrología que estudia el almacenamiento, circulación y distribución de las aguas terrestres en la zona saturada de las formaciones geológicas, teniendo en cuenta sus propiedades físicas y químicas, sus interacciones con el medio físico y biológico y sus reacciones con la acción del hombre (Custodio y Llamas, 1976).

Se define un acuífero como el estrato o formación geológica que permite el paso del agua a través de poros o grietas, en cantidades económicamente útiles para que el hombre pueda aprovecharla (Custodio y Llamas, 1976). Existen diferentes tipos de acuíferos, que pueden clasificarse en función de sus características (depósitos fluviales, deltaicos, eólicos o glaciares, entre otros) o según la presión hidrostática del agua contenida en ellos.

Esta última clasificación incluye acuíferos libres, también llamados no confinados o freáticos, cuando existe una superficie libre del agua contenida en ellos, que está en equilibrio con la presión atmosférica. Otro tipo son los acuíferos confinados, cautivos o a presión, en los cuales el agua está sometida a una presión superior a la atmosférica y ocupa la totalidad de los poros o huecos de la formación geológica que lo contiene. Un tercer tipo de acuífero o variante de los confinados, corresponde a los semiconfinados, en los que el piso y/o el techo (límites inferior y superior) es semipermeable, constituyendo un acuitardo, material que permite una lenta filtración vertical del agua. 
Al estudiar las aguas subterráneas, es muy importante conocer sus características hidrodinámicas e hidroquímicas.

En relación a la hidroquímica, cabe destacar que el agua, cuya molécula está formada por dos átomos de hidrógeno y uno de oxígeno, posee propiedades físico químicas singulares. Una de ellas es la gran capacidad de disolución, que hace que pueda contener gran cantidad de sustancias disueltas, que forme parte de otras o las ataque.

De este modo, las aguas subterráneas naturales presentan distintas sustancias disueltas, mayormente en estado iónico (Custodio y Llamas, 1976). Algunos iones son los

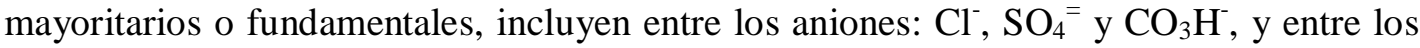
cationes: $\mathrm{Na}^{+}, \mathrm{Ca}^{++}$y $\mathrm{Mg}^{++}$. Por otro lado, existen iones minoritarios, que se encuentran formando menos del $1 \%$ del contenido iónico total. Pueden mencionarse entre otros $\mathrm{NO}_{3}{ }^{-}$, $\mathrm{CO}_{3}{ }^{2}, \mathrm{~K}^{+}$y $\mathrm{Fe}^{++}$, el $\mathrm{NO}_{2}^{-}, \mathrm{F}^{-}, \mathrm{NH}_{4}^{+}$y $\mathrm{Sr}^{++}$. Los iones $\mathrm{NO}_{3}^{-}, \mathrm{CO}_{3}{ }^{=}$y $\mathrm{K}^{+}$pueden considerarse como mayoritarios en algunos casos. Un tercer grupo son los elementos traza, que se presentan en cantidades difícilmente medibles por medios químicos usuales. En general se encuentran de esta forma los iones metálicos derivados del $\mathrm{As}, \mathrm{Sb}, \mathrm{Cr}, \mathrm{Pb}$, $\mathrm{Cu}, \mathrm{Zn}, \mathrm{Ba}, \mathrm{V}, \mathrm{Hg}$, U, etc.

La composición química del agua puede clasificarse y representarse según diferentes metodologías, como indica Catalán Lafuente (1969), entre las que se incluyen los diagramas de Schoeller y Piper, utilizados en este trabajo.

En este aspecto interesa particularmente la presencia de nitratos en aguas subterráneas. Las sustancias nitrogenadas presentes en la materia orgánica, sufren procesos que las convierten en amonio, nitritos o nitratos, dependiendo de que el medio sea reductor u oxidante, y que exista presencia de actividad bacteriana (Catalán Lafuente, 1969).

El origen del ión nitrato proviene mayormente de la oxidación bacteriana de las materias orgánicas, contenidas en los efluentes cloacales vertidos en pozos absorbentes, fosas sépticas o letrinas. Si bien no está comprobada su toxicidad, se recomienda que las aguas con alto contenido no sean utilizadas para bebida, especialmente en niños de menos de tres meses de edad y en adultos con ciertos problemas patológicos, debido a que poseen ciertas condiciones en la microflora digestiva que permiten la reducción a nitritos pudiendo provocar cianosis (Catalán Lafuente, 1969).

Con respecto a la hidrodinámica, se debe considerar que el agua en el subsuelo puede encontrarse en diferentes condiciones, desde agua que circula libremente hasta aquella que se encuentra firmemente fijada en el interior de las estructuras cristalinas. Existen dos zonas principales, una de aireación, que incluye subzonas de 
evapotranspiración, intermedia y capilar, a medida que se profundiza y donde el agua retenida llena sólo una parte de los espacios porosos; y una zona de saturación o de agua freática. El límite entre ambas está dado por la superficie freática (Davis y De Wiest, 1971).

El agua subterránea se desplaza desde los niveles energéticos más altos a los más bajos, debido a que su energía proviene de las diferencias de nivel y de presión. El movimiento del agua subterránea puede ser explicado a través de una ley conocida como Ley de Darcy, quien concluyó que en el movimiento a través de lechos de arena estratificados horizontalmente, el caudal Q era inversamente proporcional a la longitud del camino recorrido y directamente proporcional a la pérdida de energía y a un coeficiente $\mathrm{K}$, dependiente de la naturaleza de la arena.

Se debe considerar que en acuíferos con flujos laminares el caudal subterráneo está determinado por esta ley, la cual se expresa en la siguiente fórmula (Custodio y Llamas, 1976):

Donde

$$
\mathrm{Q}=\mathrm{K} \cdot \mathrm{A} \cdot \mathrm{I}
$$

Q: es el caudal circulante en un acuífero (m3/día)

A: es la superficie (m2)

I: el gradiente hidráulico (determinado por la diferencia "h" de la altura del nivel sobre la distancia "l" recorrida a lo largo del flujo)

$\mathrm{K}$ : el coeficiente de permeabilidad (m/día). Es una medida de la capacidad de un material para transmitir agua u otro fluido a través de sus intersticios

La Ley de Darcy permite comprender la lentitud del movimiento de las aguas subterráneas. Por este motivo, los acuíferos pueden mostrar la contaminación muchos años después de que el proceso responsable se halla producido. De igual forma, la recuperación del acuífero puede ser muy lenta. Además, el gran volumen de agua contenido permite que las contaminaciones extensas se manifiesten tardíamente y que los eventos puntuales no aparezcan hasta después de un largo tiempo, cuando sean detectados en captaciones en explotación (Custodio y Llamas, 1976).

Para el estudio del flujo subterráneo se analizan mapas equipotenciales, los que se construyen a partir del trazado de líneas isopiezas, curvas de igual nivel de altura piezométrica o altura del agua, cómo se explica en el ítem metodología.

Dentro de las diferentes captaciones de agua subterránea interesan especialmente los pozos. Su forma generalmente cilíndrica y su diámetro mucho menor que la profundidad. El agua ingresa a través de las paredes, determinando un flujo de tipo radial. El efecto primario del bombeo de pozos es generar un descenso del nivel del agua. Éste es 
necesario para establecer un gradiente hidráulico suficiente para poner el agua en movimiento hacia el pozo.

La realización de una captación, requiere de parámetros de diseño, que incluyen ciertas consideraciones, requisitos o técnicas tendientes a proteger el pozo de toda fuente de contaminación; construirlo con la profundidad y el diámetro adecuados de acuerdo con el caudal de extracción; y cuyos materiales cumplan las condiciones de resistencia y durabilidad. Estos criterios se detallan en el ítem 5.4.3.

Ante el objetivo de lograr una perforación eficiente, se debería lograr el conocimiento de las características hidrogeológicas, especialmente de los materiales constituyentes del acuífero, acompañado de un ensayo de bombeo que permita conocer su funcionamiento.

Las aguas residuales o efluentes cloacales, genéricamente denominadas efluentes domiciliarios, se generan a partir de los diferentes usos del recurso. Éstas contienen diversos contaminantes, entre los que se destacan los microorganismos patógenos como bacterias, virus y parásitos, y la materia orgánica, constituida por materia fecal, papel higiénico, restos de alimentos, jabones y detergentes (Mariñelarena, 2006). El manejo adecuado de las mismas resulta imprescindible para la protección de la salud pública, por lo cual estas aguas deberían ser tratadas (CoFAPyS, 1993). Existen diferentes modos de tratamiento, a través de procesos físicos (sedimentación), químicos (adición de reactivos químicos), biológicos (utilización de microorganismos), y sistemas de tratamiento por aplicación al terreno, el cual incluye procesos físicos, químicos y biológicos, generando la oxidación de la materia orgánica.

En muchos casos, tal como en la zona de estudio, se realiza la disposición in situ y sin tratamiento de los efluentes domiciliarios. Puede llevarse a cabo según diferentes métodos, sea por derrame sobre la superficie del terreno, por dilución de los efluentes en aguas superficiales, o por disposición subsuperficial. Este último utiliza excavaciones para verter las aguas residuales en el terreno, por debajo de su superficie.

Dentro de las instalaciones sanitarias domiciliarias, existen letrinas con o sin arrastre hidráulico, cámaras sépticas, pozos absorbentes, campos de infiltración y percolación subsuperficial, entre otros (CoFAPyS, 1993). Es importante el tratamiento que se lleve a cabo previo a la disposición. La decantación de los sólidos de mayor tamaño en cámaras sépticas previas a la disposición subsuperficial, puede colaborar en la degradación y disminuir los aportes orgánicos.

Existen numerosos criterios de diseño para los sistemas de tratamiento y disposición de efluentes domiciliarios. En el caso de las cámaras sépticas, deben tener ventilación y 
accesos herméticos y con posibilidad de realizar tareas de limpieza, así como requieren una cobertura superficial de tierra que favorece la amortiguación de los cambios de temperatura.

Una vez que los efluentes son depositados en pozos absorbentes y letrinas, sufren diferentes procesos de dilución, retardación y eliminación, tanto en la zona no saturada como en la saturada, que conllevan a la reducción de los contaminantes (Custodio y Llamas, 1976). Tanto el tiempo transcurrido como la temperatura, afectan los procesos de eliminación por descomposición microbiana. En condiciones normales de digestión, al cabo de un año es casi nula la supervivencia de los diferentes patógenos presentes. Los virus sobreviven generalmente hasta 6 meses en el suelo; las bacterias lo hacen alrededor de 2 meses, pudiendo llegar a 3 años; los protozoos tienen la menor supervivencia que no supera 10 días; mientras que los helmintos viven generalmente 2 años en el suelo, alcanzando los 7 años en algunos casos (CoFAPyS, 1993).

Las aguas residuales domésticas poseen una microflora característica, principalmente bacterias de putrefacción, como Pseudomona fluorescens, P. Aeruginosa, Bacillus cereus, Aerobacter cloacae, Proteus vulgaris, entre otras (Rheinheimer, 1987). Además, presentan una alta proporción de coliformes, los que constituyen un indicador de la contaminación fecal. Estas aguas son también portadoras de agentes patógenos para la especie humana, entre los que pueden citarse las bacterias intestinales Salmonella typhi y S. Parayphi, causantes de las enfermedades tíficas; el Vibrio cholerae, agente del cólera; el bacilo tuberculoso Mycobacterium tuberculosis. Entre los virus pueden encontrarse los causantes de la poliomielitis y la hepatitis.

La legislación argentina detalla los microorganismos que deben considerarse para determinar la aptitud de las aguas para consumo humano, tal como se detallará en la Metodología. En caso de que las muestras analizadas superen los niveles permisibles fijados, se convierten en aguas microbiológicamente no aptas para consumo, generando así un riesgo para la salud de la población que utiliza el recurso hídrico.

La información sobre la cantidad y la calidad de los recursos naturales es esencial para el desarrollo sustentable. Es muy importante la información sobre el agua, su disponibilidad, calidad y uso, ante la necesidad de mejorar la eficiencia del mismo. Una herramienta útil para tal fin son los indicadores de sustentabilidad. Deben brindar una imagen representativa de las condiciones ambientales, así como las presiones y respuestas de la sociedad; generar información concisa y clara, fácil de comprender y utilizar (OECD, 2003), y responder a cambios en el ambiente y las actividades humanas relacionadas, y ser útiles para realizar comparaciones entre diferentes sitios. 
Es fundamental la construcción de un sistema de indicadores ambientales, el cual debe ser la expresión integrada de un conjunto de índices guía que, con un propósito claro, permitan obtener una visión integral y consistente de una problemática ambiental en un sitio determinado y para un período de tiempo dado (Guerrero et al., 2007).

Los indicadores antes descriptos, constituyen una herramienta de gestión ambiental, útil pero no suficiente. Es fundamental contar con diferentes estrategias tendientes a la sustentabilidad, tanto ecológica, económica y social, una de ellas, es la educación ambiental.

Ésta se caracteriza por su visión interdisciplinaria, como un encuentro de saberes, resultado de la articulación de diversas disciplinas y experiencias educativas, que permiten tener una percepción integrada del ambiente y emprender acciones racionales y en respuesta a las necesidades sociales (Conferencia Intergubernamental sobre Educación Ambiental, 1977).

En este sentido, la educación ambiental puede entenderse como un tema transversal al desarrollo cultural de la sociedad y, por tanto, su contribución a la búsqueda de soluciones de los problemas ambientales viene dado por su inserción en el quehacer cotidiano de la población (Márquez Fernández, 2003). Consecuentemente, deberá abarcar las actividades y grupos sociales cuyas acciones influyen en la relación de la sociedad y el ambiente. Resulta imprescindible para lograr un cambio en las relaciones de las personas con su entorno, como forma de mejorar el uso y gestión de los recursos naturales y reducir los impactos al ambiente, y en este caso al recurso hídrico. Se trata de tareas educativas con énfasis preventivo, tratando de promover un cambio de hábitos y actitudes cotidianas que se concreten en acciones ambientalmente adecuadas.

Las estrategias ambientales deben enmarcarse en el enfoque de la Gestión Integrada de los Recursos Hídricos (GIRH), también conocido como Manejo Integrado (MIRH), el cual plantea un tratamiento de los temas del agua de una manera sustentable y sistémica.

El MIRH es definido como "un proceso que promueve el manejo y desarrollo coordinado del agua, la tierra y los recursos relacionados, con el fin de maximizar el bienestar social y económico resultante de manera equitativa sin comprometer la sustentabilidad de los ecosistemas vitales" (GWP, 2000).

En cada región o área, y considerando localmente las problemáticas ambientales vinculadas al agua, la GIRH plantea el establecimiento de estrategias de gestión sustentable adecuadas, que integren las aguas superficiales con las subterráneas, la calidad y la cantidad del recurso, los usuarios de aguas arriba con los de aguas abajo, y la 
incorporación del tema en la toma de decisiones, considerándolo como política pública y transectorial.

Si bien su definición es amplia y puede parecer utópica, lo importante es la concepción de integración y vinculación de los subsistemas natural y social, rompiendo con el manejo tradicional y fragmentado de los recursos hídricos. 


\section{METODOLOGÍA}

Para la realización del presente trabajo se llevaron adelante diferentes tareas, utilizando diversos métodos, estrategias, instrumentos y materiales, que se detallan a continuación.

\subsection{Información antecedente}

En primer lugar, se realizó la búsqueda y análisis de antecedentes sobre los subsistemas físico y social. Se localizó cartografía del área de estudio, y se recopilaron datos hidrometeorológicos e hidrogeológicos, censos de población, estudios previos del recurso hídrico, artículos periodísticos sobre el tema. Además se relevó información actualizada sobre el manejo del agua en Tandil, en relación a los servicios de agua potable y red de cloacas, y las principales fuentes de contaminación.

Esta tarea se llevó adelante a través de la indagación en bibliografía, sitios de Internet, datos de instituciones públicas, y conocimientos brindados por informantes calificados. Cabe destacar que una buena parte del conocimiento sobre el recurso hídrico subterráneo en Tandil proviene de los estudios previos realizados por el grupo de investigación del Centro de Investigaciones y Estudios Ambientales (CINEA), en el marco del cual se ha llevado adelante este trabajo.

\subsection{Caracterización del medio físico a escala regional y local}

\subsubsection{Descripción de la cuenca del Arroyo Langueyú}

Esta labor consistió en primera instancia, en el análisis regional de las características de la cuenca del Arroyo Langueyú, para lo cual se tuvieron en cuenta: cartas topográficas, datos geológicos e hidrológicos, estudios previos sobre el sistema geohidrológico. Se describieron las características geológicas, geomorfológicas, hidrológicas, geohidrológicas, y climatológicas.

Se consideró el balance hídrico para el período 1900-2003 realizado por Ruiz de Galarreta (2006), según la metodología de Thornthwaite y Mather (1957).

Para la zona de estudio, se realizó el balance hídrico de Thornthwaite-Mather en forma seriada, utilizando los valores diarios de precipitación para un período de tres años (2005-2008). Si bien el lapso de medición de niveles estáticos en que se basa este trabajo 
ocupa desde septiembre de 2007 al mismo mes de 2008, se inició dicho balance dos años antes para obtener un almacenaje de agua en el suelo lo más ajustado posible.

Se lo efectuó cotejando mes a mes los valores de precipitación (datos obtenidos del Servicio Meteorológico Nacional, Estación Tandil Aeródromo) versus la evapotranspiración potencial, considerando en cada momento la capacidad de almacenaje de agua del suelo predominante en la zona, el cual, de acuerdo al tipo de suelo y vegetación predominante, fue establecido en $150 \mathrm{~mm}$. Una vez completado el ciclo, se determinaron los déficits hídricos, los excesos y la EVTr del período de análisis.

De esta forma fue posible continuar en el conocimiento de la dinámica del sistema hídrico subterráneo.

\subsubsection{Análisis de la hidrodinámica subterránea}

Se realizó el análisis hidrodinámico en la cuenca y en la zona de estudio seleccionada, a partir del censo de pozos, medición de niveles y muestreo, a fin de conocer, mediante la construcción de mapas temáticos, las características del sistema así como las variaciones temporales.

A nivel de la cuenca del Arroyo Langueyú se llevó a cabo un relevamiento preliminar del recurso hídrico subterráneo. Dicho trabajo se hizo en forma conjunta con otros integrantes del proyecto en que se enmarca esta investigación, durante los meses de abril y mayo de 2007.

La metodología de trabajo consistió en la realización de un censo de pozos, es decir la búsqueda de perforaciones existentes en toda la cuenca, en las cuales se midieron los niveles estáticos del agua subterránea. Para dicho relevamiento se utilizó una planilla de campo que se presenta en el Anexo I.

En cada perforación, se midió la profundidad del nivel freático a través del uso de una sonda, como se ilustra en las Figuras 5, 6 y 7. 




Figura 5. Medición del nivel freático en perforación con bomba sumergida.

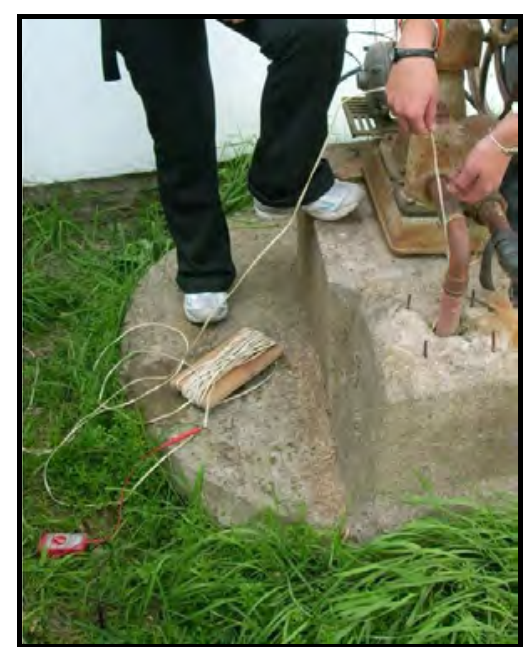

Figura 6. Medición del nivel freático en perforación con bombeador.

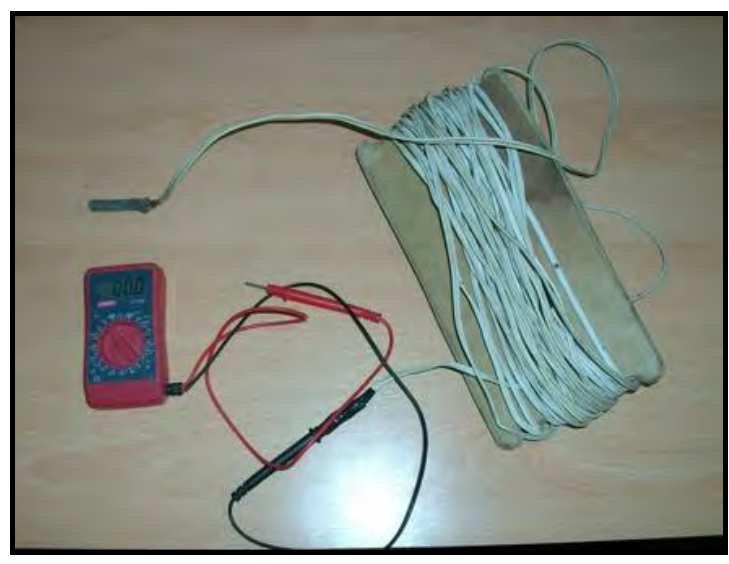

Figura 7. Sonda utilizada para la medición de niveles.

La determinación del nivel piezométrico o de energía en relación al del mar, se llevó a cabo considerando la profundidad freática medida en el campo, y la cota topográfica del sitio donde se ubica la perforación, obtenida de la carta topográfica Tandil, Hoja 3760-23-4, en escala 1:50.000 (IGM, 1955). El cálculo consistió en la diferencia entre la cota topográfica (z) y la profundidad del nivel freático (h), de la cual se obtiene el nivel estático $(\mathrm{H})$. Cuando la perforación posee un brocal, construcción, o bomba en superficie, debe considerarse la altura de la boca de pozo (bp).

A partir del censo preliminar, en el mes de junio de 2007 se efectuó el relevamiento detallado en un total de 60 puntos distribuidos homogéneamente en toda la cuenca del Arroyo Langueyú. De dicho relevamiento se obtuvo la superficie freática a nivel regional, así como el total de muestras que fueron analizadas físico-químicamente, para conocer las características generales del agua subterránea en la cuenca. Este levantamiento se realizó 
en forma secuencial durante un año hidrológico, a fin de analizar las fluctuaciones estacionales del nivel freático a lo largo de dicho ciclo.

Esta misma metodología de trabajo, pero a una escala de mayor detalle, es la que se aplicó en el Barrio Cerro Los Leones. Se inició con la interpretación de la hidrodinámica subterránea, a través de censos de perforaciones. Para ello se comenzó con un relevamiento de pozos existentes en el barrio, distribuidos homogéneamente. Una vez detectados 15 sitios, se realizaron las mediciones trimestrales de la profundidad del nivel freático y se construyeron mapas de isoprofundidades. Las fechas correspondieron a los meses de septiembre y diciembre de 2007 y en marzo, junio y septiembre de 2008, abarcando así un año hidrológico completo y permitiendo el estudio de las variaciones temporales del recurso hídrico subterráneo.

Estos datos permitieron conocer los niveles piezométricos $\mathrm{y}$, mediante la construcción de mapas equipotenciales, el sentido de escurrimiento subterráneo local. Dicha cartografía fue elaborada a través del software Surfer 8.

Para conocer la importancia de la recarga local, se efectuó el balance de cloruros, a través de la metodología planteada por Custodio (1997). La misma considera la incorporación de cloruros en las aguas provenientes de la precipitación a través de su recorrido hacia el nivel freático. Para ello se consideraron las concentraciones de cloruros en las precipitaciones, así como las determinadas en la red de muestreo (censos de septiembre y diciembre de 2007).

La ecuación utilizada incluye:

$$
\mathrm{PCl} \text { 'p }=\mathrm{R} \mathrm{Clr}
$$

Siendo:

P: precipitación

R: recarga

Clr: concentración de cloruros de la recarga

Cl'p: concentración de cloruros de la lluvia más la deposición seca

\subsubsection{Caracterización de la hidroquímica subterránea}

En la misma red de perforaciones se llevó adelante el muestreo de agua para su posterior análisis físico-químico, en las mismas fechas determinadas para la medición de los niveles freáticos.

Para la toma de muestra, se utilizaron recipientes plásticos PET de 1 litro, como se observa en la Figura 8. Los mismos fueron correctamente enjuagados con el agua correspondiente al sitio de muestreo, y se completaron sin dejar aire en su interior. 
Además de las 15 perforaciones utilizadas para el cálculo de niveles estáticos, se agregaron otros 3 sitios de muestreo, dos de ellas correspondientes a los establecimientos educativos locales y la tercera es una compartida entre el Centro Comunitario Barrial y la Sala de Atención Primaria a la Salud.

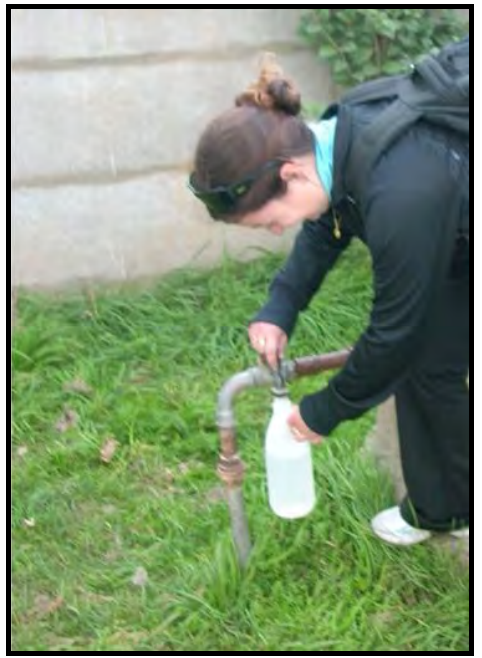

Figura 8. Toma de muestra para análisis químico.

En ellas se midió y se registró en el campo, el pH (método colorimétrico), así como la conductividad eléctrica con un conductivímetro marca ORION 105 Aplus (Figuras 9 y 10), con cuyos datos se construyó el mapa de conductividad eléctrica específica. A partir de estos valores, se estimó la salinidad total según Custodio y Lamas (1976).

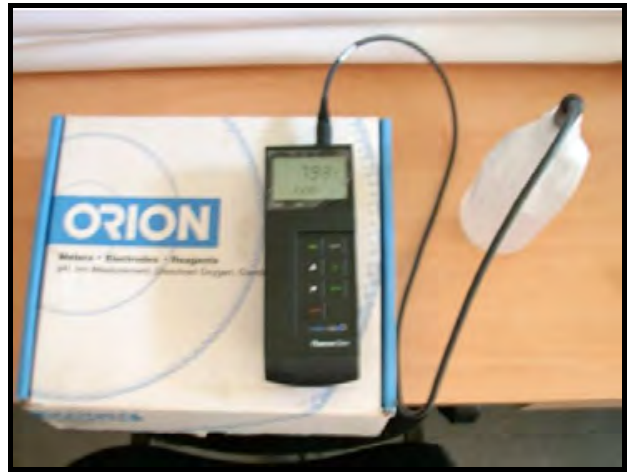

Figura 9. Conductivímetro.

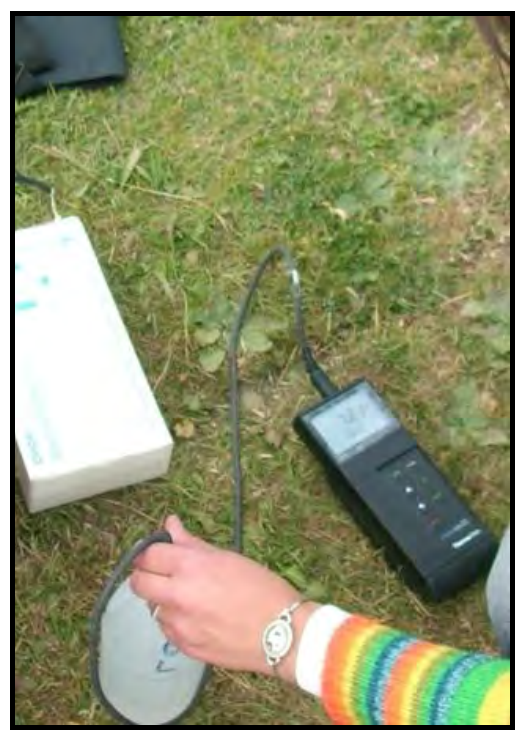

Figura 10. Medición de conductividad eléctrica en un sitio de muestreo. 
La Licenciada Corina Iris Rodriguez realizó la detección de los iones mayoritarios, en el Laboratorio de Análisis Bioquímicos y de Minerales (LAByM) del Departamento de Fisiopatología, Facultad de Ciencias Veterinarias - UNCPBA, bajo la dirección de los Doctores Miguel Ángel Quiroga y Roberto D. Landa.

Entre los cationes se midieron: Sodio, Calcio, Magnesio y Potasio, mediante espectrometría de absorción atómica. El equipo de medición utilizado se presenta en la Figura 11.

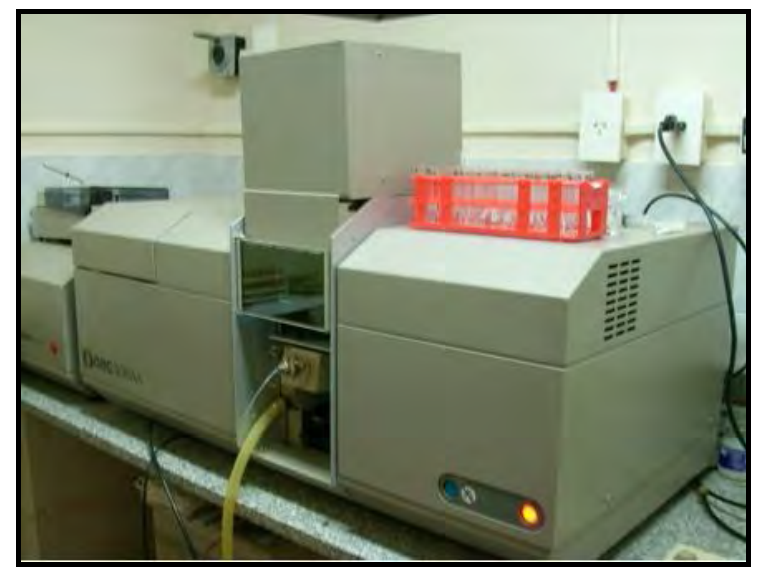

Figura 11. Equipo de espectrometría de absorción atómica.

Con respecto a los aniones, se analizaron las concentraciones de bicarbonatos (método de titulación), cloruros (método argentométrico) y sulfatos (método turbidimétrico) como se observa en las Figuras 12, 13 y 14, respectivamente. Además, se incluyó la medición de nitratos a través del método espectrométrico ultravioleta selectivo (Figura 14), ya que este compuesto puede incrementarse significativamente por contaminación antrópica en áreas urbanizadas. Todos se llevaron a cabo según los métodos normalizados (APHA, AWWA, WPCF, 1992). Para posibilitar la interpretación de los resultados y evaluar su relación con la hidrodinámica subterránea, se construyeron mapas con curvas de isoconcentraciones de los iones mayoritarios, también confeccionados mediante el software Surfer 8.

Las concentraciones iónicas detectadas, se cotejaron con los valores índices establecidos en el Código Alimentario Argentino - CAA (1969, actualizado en 2007) para determinar su potabilidad para agua de consumo humano.

Asimismo, se confeccionaron esquemas de representación de análisis químicos de aguas, tales como los Diagramas de Piper y de Schoeller. 


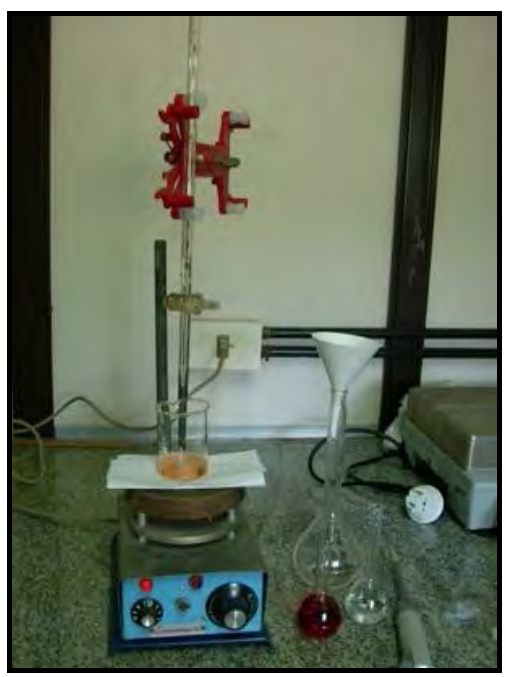

Figura 12. Determinación de bicarbonatos.

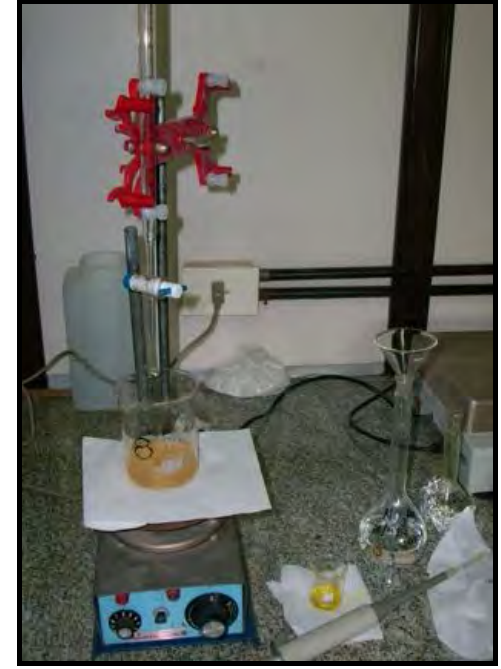

Figura 13. Determinación de cloruros.

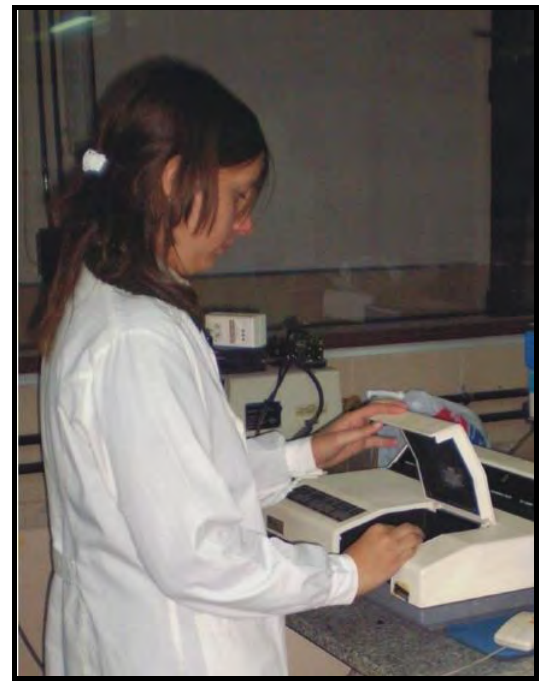

Figura 14. Espectrómetro para la medición de sulfatos y nitratos.

\subsubsection{Evaluación de la calidad microbiológica}

En las 18 perforaciones antes indicadas, se efectuó el muestreo para la realización de análisis microbiológicos.

La Licenciada Corina Iris Rodriguez realizó los análisis en el Laboratorio de Microbiología de los Alimentos, de la Facultad de Ciencias Veterinarias - UNCPBA, bajo la dirección de la Médica Veterinaria Anahí Tabera. Se efectuaron de acuerdo a lo estipulado por el Código Alimentario Argentino que, en su artículo 982 (actualizado en 2007), establece la detección de bacterias aeróbicas mesófilas, coliformes totales, Escherichia coli y Pseudomona aeruginosa para la determinación de la aptitud del agua para consumo humano. 
A continuación se indican los niveles permisibles y se describen las técnicas de detección de cada microorganismo (APHA, AWWA, WPCF, 1992).

- Bacterias aeróbicas mesófilas:

Se determinó el número de bacterias mesófilas por el método de recuento en placa. El CAA establece como límite hasta $500 \mathrm{UFC} / \mathrm{ml}$. (UFC: Unidades Formadoras de Colonias). En primer lugar se realizaron diluciones de las muestras $\left(10^{-1}\right.$ y $\left.10^{-2}\right)$ en agua peptonada estéril y se sembraron en profundidad (Figura 15), en medio de cultivo Agar Plate Count. Se colocó la placa durante 24 horas a $37^{\circ} \mathrm{C}$. Posteriormente, se realizó el recuento de UFC (Figura 16) y se calculó el valor medio.

\section{- Bacterias coliformes:}

En este caso, la legislación plantea como límite hasta 3 bacterias $/ 100 \mathrm{ml}$. Se determinó el número más probable (NMP) de bacterias coliformes totales en $100 \mathrm{ml}$. Para ello se realizó la siembra por triplicado en tubos con caldo Mac Conkey o Lactosa bilis verde brillante (LBVB) con diferentes concentraciones y volúmenes de muestra (Figuras 17 y 18). Posteriormente, se incubaron los tubos a $37^{\circ} \mathrm{C}$ por $48 \mathrm{hs}$. Se contaron los tubos positivos (aquellos con cambio de coloración en el caldo y producción de gas en la campana de Durkham) y, a través de la tabla de Hoskins, se determinó el NMP.

\section{- Escherichia coli:}

El CAA establece la ausencia de esta bacteria, en $100 \mathrm{ml}$ de muestra. Al detectarse tubos positivos en el análisis de bacterias coliformes, se pasó a un tubo con caldo Mac Conkey o LBVB (Figura 19) y se incubó a $45^{\circ} \mathrm{C}$ durante 48 hs. En caso de ser positivo, se confirmó mediante siembra por estrías en superficie (Figura 20) en agar Eosina azul de metileno (EMB), a $37^{\circ} \mathrm{C}$ durante 24 a 48 horas. Ante la presencia de E. coli se observó el crecimiento de color verde metálico.

\section{- Pseudomona aeruginosa:}

En este caso, la legislación argentina también considera la ausencia en $100 \mathrm{ml}$ de muestra. El aislamiento se realizó a partir de tubos de Mc Conkey o LBVB (utilizados en el aislamiento de coliformes) con desarrollo de velo (Figura 21). Una vez detectados los mismos, se sembró en superficie, en placas con Agar Cetrimide (Figura 22), incubándose a $37{ }^{\circ} \mathrm{C}$, entre 24 y 48 horas. La presencia de la bacteria, se observó mediante el crecimiento de color verde-amarillento. 


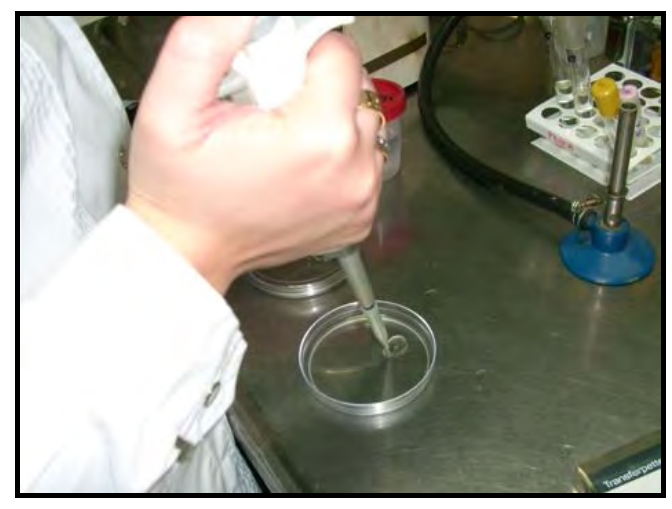

Figura 15. Siembra en profundidad para la determinación de bacterias mesófilas.

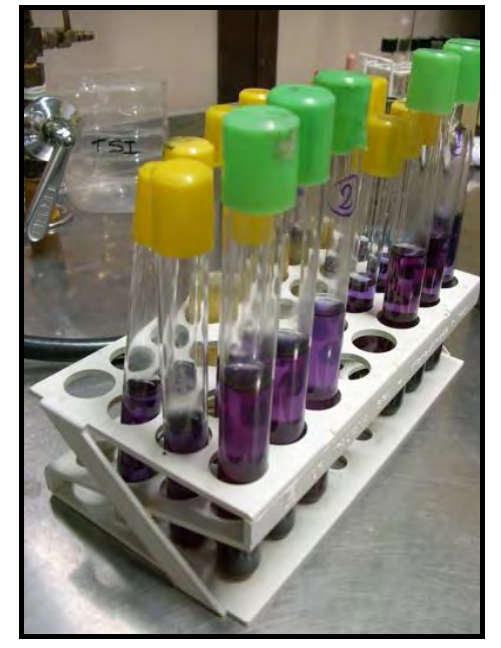

Figura 17. Tubos para determinación de coliformes totales

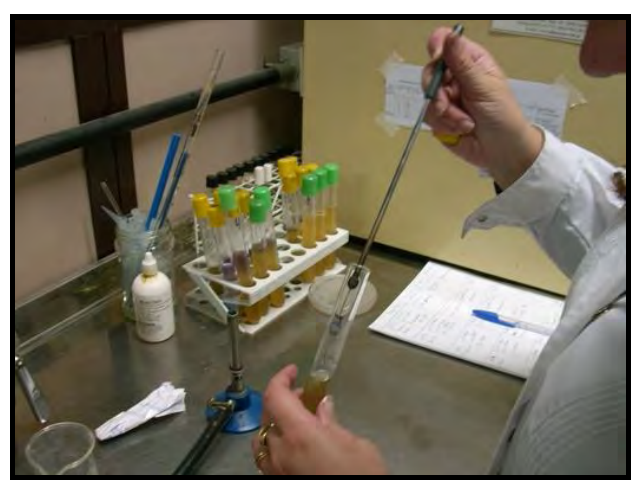

Figura 19. Aislamiento para determinación de E. coli

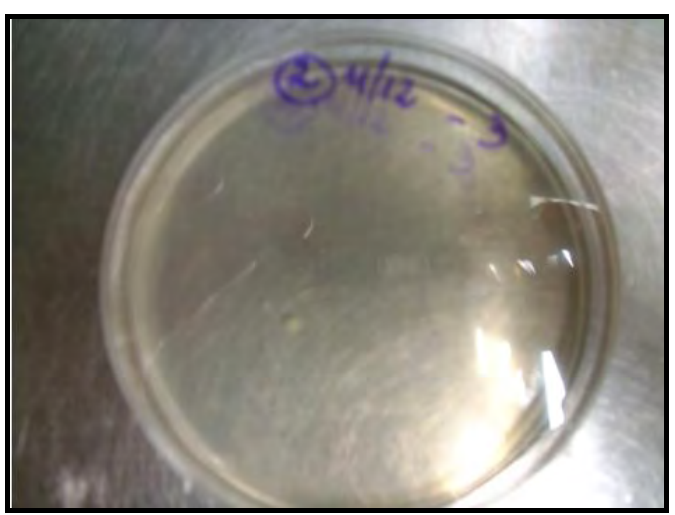

Figura 16. Placas para recuento de UFC (mesófilos)

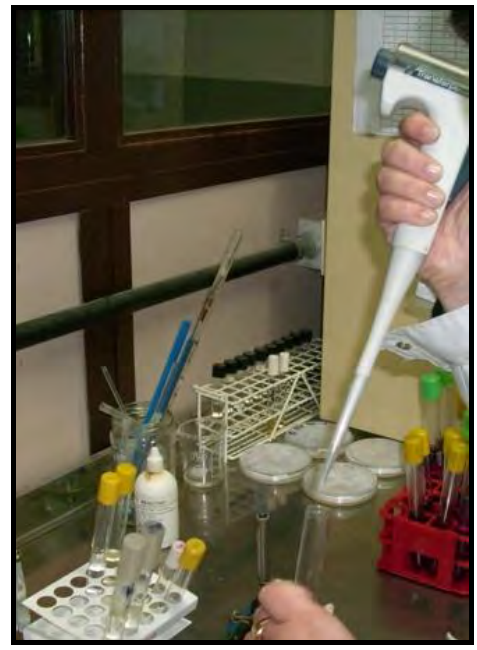

Figura 18. Siembra en tubos para determinación de coliformes totales

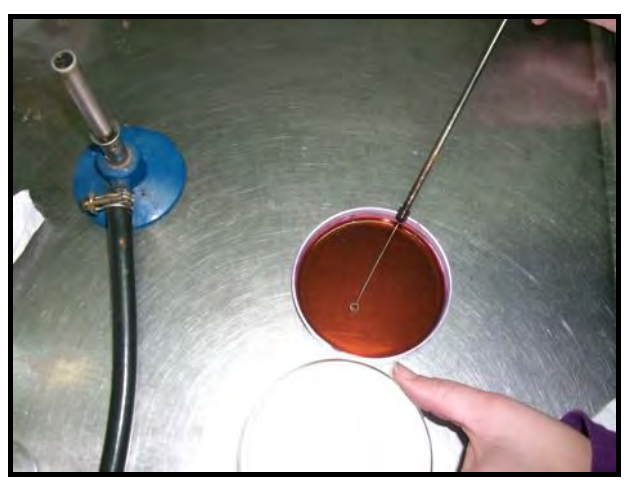

Figura 20. Siembra en superficie para determinar E. coli 


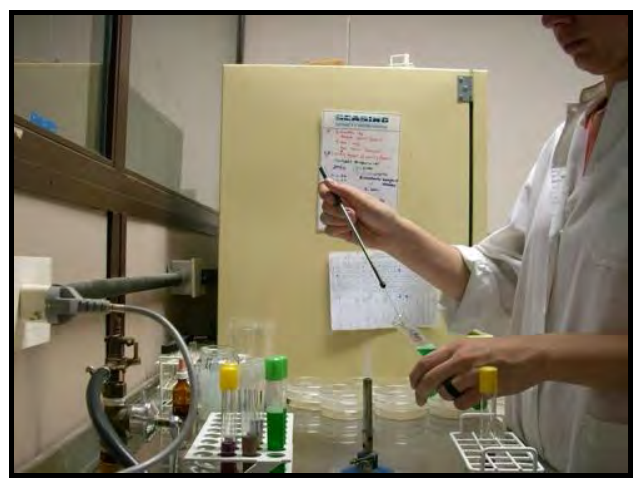

Figura 21. Aislamiento para determinar $\mathrm{P}$. aeruginosa

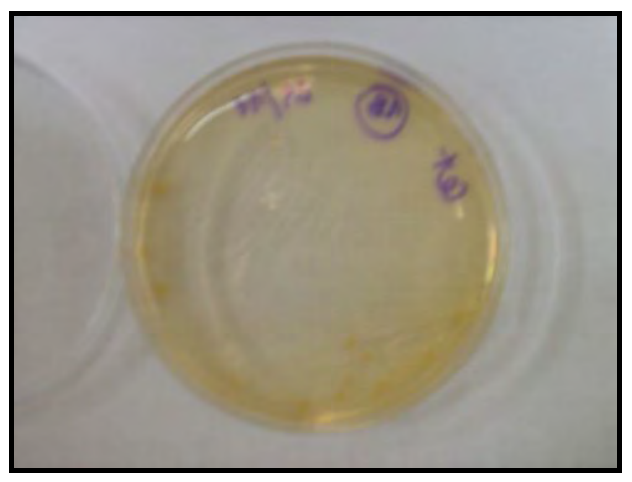

Figura 22. Placas para el análisis de $\mathrm{P}$. aeruginosa

\subsection{Caracterización del subsistema social}

\subsubsection{Entrevistas a informantes calificados}

Con respecto al análisis y comprensión del subsistema social, en primer lugar se identificaron y seleccionaron informantes calificados para la realización de entrevistas semi-estructuradas, a partir de las cuales se relevó información cuali-cuantitativa sobre las condiciones de manejo actual de los recursos hídricos en la ciudad.

Entre los informantes entrevistados se incluyeron habitantes de diferentes sectores de la ciudad y del barrio en estudio; personal de Obras Sanitarias Tandil, de la Municipalidad de Tandil, de la Dirección de Atención Primaria a la Salud, de la Secretaría de Desarrollo Social, de los Centros Comunitarios barriales.

A nivel del Barrio Cerro Los Leones, las entrevistas se basaron en las principales necesidades de la comunidad barrial, especialmente el acceso a servicios de agua potable y desagües cloacales. Asimismo, se indagó sobre la red social que interviene en el proceso de apropiación, explotación y uso del recurso hídrico subterráneo. Por otro lado, se obtuvo información sobre las principales actividades y funciones de la Sala de Atención Primaria a la Salud y el Centro Comunitario, así como el conocimiento y registro de enfermedades de origen hídrico. Otro punto de interés consistió en las características del entorno, tales como focos de contaminación, disposición de residuos y actividades productivas entre otras.

Estas entrevistas permitieron conocer en detalle la gestión del agua en Tandil, así como los actores intervinientes en la misma, y las problemáticas ambientales relacionadas. 


\subsubsection{Realización de encuestas}

Para conocer en detalle las características de la población del Barrio Cerro Los Leones se efectuaron encuestas a una muestra de la población del Barrio. Para ello, la Licenciada Corina Rodriguez diseñó un formulario de encuesta para los habitantes del barrio, el cual se presenta en el Anexo II. El mismo fue probado previamente en algunas viviendas, con el objetivo de detectar dificultades en su ejecución, así como conocer la respuesta de los pobladores ante la indagación.

A lo largo del trabajo de campo, se abarcó un total de 44 viviendas distribuida en el barrio, a las que se les suman 2 realizadas en los establecimientos educativos del barrio, donde el formulario recibió las adaptaciones necesarias.

Los hogares encuestados incluyeron un total de 169 habitantes. Considerando las estimaciones poblacionales informadas por el Centro Comunitario barrial, que indicaron unos 300 habitantes, la población analizada representó alrededor del $50 \%$.

En el temario se abordaron diferentes cuestiones: datos generales de la persona a cargo de la vivienda, número de habitantes por vivienda, situación laboral y nivel educativo alcanzado. Maternidad, salud y antecedentes de enfermedades de origen hídrico. Datos previos de análisis del agua, modos de apropiación del recurso para diferentes usos, sistema de extracción, con detalles de la bomba, la perforación, las medidas de protección de la misma. Existencia de contaminación superficial. Almacenamiento de agua y desinfección de tanques, sistema de distribución de agua en la vivienda. En cuanto al sistema de disposición de efluentes domiciliarios se indagó sobre las características del pozo absorbente, problemas relacionados al mismo; distanciamiento entre la perforación de bombeo y dicho pozo.

\subsubsection{Caracterización de los actores de la gestión del agua}

Una tarea fundamental fue conocer y caracterizar los actores que intervienen en los procesos de explotación y uso del agua en la ciudad de Tandil, lo cual permitió comprender la gestión actual del recurso y las condiciones de apropiación del mismo.

La información recabada en las entrevistas a informantes calificados, sumada a los antecedentes sobre el uso del recurso hídrico subterráneo en la ciudad de Tandil, fueron insumos primordiales para establecer la red de actores involucrados en la problemática hídrica. 
Se siguió la metodología planteada por Dourejeanni (2000 y 2002) que indica las variables a considerar en el proceso de materialización de actores y en la participación de los mismos.

\subsubsection{Evaluación de las condiciones de explotación y uso del agua}

Conociendo los actores intervinientes en la gestión local del agua, y a través del análisis de la información procedente de las encuestas y entrevistas, se inició la evaluación de los modos de explotación y uso del recurso.

Se realizaron recorridos por la zona, con el objetivo de observar y analizar las condiciones de vida de la población, y las zonas de riesgo de contaminación del agua subterránea a partir de la determinación de diversos focos. Además, se prestó especial atención al contexto de cada perforación, principalmente las actividades realizadas en las cercanías, la presencia de residuos y animales, registrándose a través de la utilización de una cámara fotográfica digital.

Estas observaciones, conjuntamente con la información obtenida en las encuestas y la detectada en las visitas periódicas a las viviendas e instituciones en ocasión de los censos de medición y muestreo, especialmente sobre las características técnicas y constructivas de perforaciones y pozos absorbentes, y considerando los resultados sobre la calidad química y microbiológica del agua, permitieron determinar los modos de aprovechamiento y uso del recurso.

La elaboración de cartas temáticas permitió la integración y el cruce de los datos, brindando la comprensión de las relaciones entre las actividades humanas, las características del recurso y los efectos sobre el mismo.

\subsection{Análisis sistémico de la problemática local y pautas de gestión sustentable}

Se estableció la vinculación e integración entre los análisis de los subsistemas físico y socioeconómico, permitiendo abordar la situación ambiental del barrio en forma integral, considerando las interrelaciones del recurso hídrico con las dimensiones social, económica y político-institucional.

Ante el diagnóstico brindado por las etapas metodológicas antes descriptas, esta tarea consistió, por un lado, en la generación de estrategias de educación ambiental, algunas de las cuales fueron aplicadas a lo largo del trabajo de investigación. 
Por otro lado, se establecieron indicadores de sustentabilidad del recurso hídrico, útiles para evaluar la evolución temporal de la problemática, y compararla con las existentes en otras áreas de estudio.

Como tarea final, y a partir del análisis sistémico, se elaboraron pautas de gestión sustentable del recurso.

\subsubsection{Elaboración y puesta en práctica de propuestas de educación ambiental.}

Considerando la importancia de la educación ambiental para la búsqueda de soluciones, se llevaron a cabo talleres en los establecimientos educativos locales: Escuela Secundaria Básica № 15, Escuela Primaria Básica No 4 y Jardín de Infantes No 915; y además se concretó una charla abierta a la comunidad.

Estas actividades fueron realizadas una vez culminado el diagnóstico ambiental en el barrio, y en ellas se incentivó la participación de los niños y adultos, indagando sobre sus conocimientos previos y sus vivencias, con el objetivo de que sean transmisores de la información al resto de los habitantes.

Los ejes centrales de las tareas de educación ambiental fueron: importancia y usos del agua, ciclo hidrológico y sistema hídrico subterráneo, problemática ambiental local, aptitud del agua para consumo humano, efectos sobre la salud, medidas para llevar adelante en los hogares, alternativas de gestión.

\subsubsection{Establecimiento de indicadores de sustentabilidad ambiental}

En este trabajo de investigación, se utilizó el Modelo de indicadores PER (OCDE, 1993), para establecer una serie de instrumentos que permitan la evaluación y seguimiento de las condiciones de explotación y uso del recurso hídrico en el Barrio Cerro Los Leones.

Estos serán útiles para aplicar en otras áreas de estudio con una situación ambiental similar, caracterizada por la ausencia de agua potable y servicios sanitarios. Además, permitirán cuantificar la intensidad de la intervención humana sobre el recurso hídrico subterráneo (Presión); las características y calidad del mismo como resultado de sus condiciones de explotación y uso (Estado) y las acciones o medidas de gestión ambiental llevadas a cabo para corregir, mitigar o solucionar las presiones o estados (Respuesta). 
Para tal fin, se elaboraron indicadores sencillos, basados en las variables de análisis más importantes evaluadas en esta investigación y referidas a las condiciones de explotación y uso del recurso hídrico.

Para su correcta definición, se siguieron los lineamientos establecidos por Guerrero et al. (2007), describiendo cada indicador, la variable a medir, la frecuencia de monitoreo, y algunas observaciones como limitaciones detectadas para su evaluación.

\subsubsection{Generación de pautas para la gestión sustentable del recurso hídrico.}

El contacto directo con los habitantes en sus viviendas, permitió conocer la situación de cada familia con relación al agua y brindar alternativas ante los problemas detectados.

En este caso, no se ha seguido una metodología preestablecida, sino que se generaron diferentes pautas de gestión ambiental, a partir del diagnóstico de las condiciones de apropiación del recurso hídrico y sobre la base del enfoque de la gestión integral (GIRH) antes descripto. Dichas pautas, fueron consideradas desde tres perspectivas: las referidas a la planificación y el control, las dirigidas a la capacitación y educación ambiental, y aquellas medidas estructurales y técnicas, entre otras.

Todas ellas pretenden mejorar las condiciones de vida, disminuir el riesgo de contraer enfermedades hídricas, así como mantener y/o mejorar la calidad del agua en el área de estudio. 


\section{SUBSISTEMA FÍSICO-NATURAL}

\subsection{Caracterización regional}

El área de estudio se ubica en el partido de Tandil, situado en el centro sudeste de la provincia de Buenos Aires y localizado en el sector central del Sistema de Tandilia, abarcando una superficie de $4935 \mathrm{~km}^{2}$.

Las cuencas que cubren el partido corresponden a las de los siguientes arroyos: de los Huesos, Chapaleofú, Langueyú, El Perdido, Tandileofú, Las Chilcas, Napaleofú y Quequén Chico.

La ciudad de Tandil se encuentra ubicada sobre la cuenca del arroyo Langueyú, la cual se desarrolla sobre el faldeo Norte de las sierras de Tandilia. La Figura 23 representa la mencionada cuenca, con su mayor altura al sur, en la zona serrana, descendiendo hacia el NE, donde encuentra el límite con el partido de Ayacucho. Drena sus aguas hacia el NE en concordancia con la pendiente regional. En la cuenca alta, se localiza la ciudad a unos 180 metros de altura sobre el nivel del mar, y a unos $6 \mathrm{~km}$. al oeste de la misma, se ubica el Barrio Cerro Los Leones.

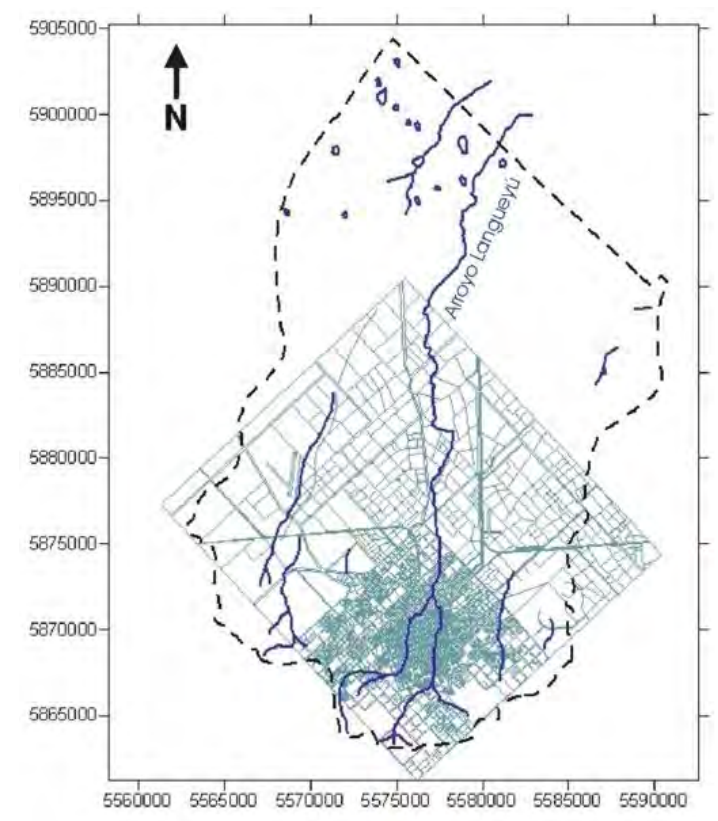

Figura 23. Cuenca del Arroyo Langueyú y ejido urbano.

El arroyo Langueyú nace en las sierras de Tandilia producto del aporte de cuencas intraserranas, ubicadas al sur de la ciudad. El arroyo posee obras de regulación, la más importante es el Dique del Fuerte al sur de la ciudad, construida en el año 1957. A partir del pie de la presa, comienza a ser conocido con el nombre de Arroyo del Fuerte cuyo 
recorrido, actualmente entubado, atraviesa la ciudad por su sector este hasta las cercanías de la Ruta Provincial № 226. Por el oeste del casco urbano pasa el arroyo Blanco el cual se une al anterior, aguas arriba de la mencionada ruta. A partir de allí se denomina definitivamente Arroyo Langueyú.

La zona considerada en este estudio como cuenca del arroyo Langueyú abarca unos $600 \mathrm{~km}^{2}$ hasta el límite con el partido de Ayacucho, mientras que el área de la cuenca alta, hasta la Ruta Nacional 226, es de $120 \mathrm{~km}^{2}$, representando el $20 \%$ del total de la cuenca. A efectos de este estudio se seleccionó como límite NE la división política entre los partidos de Tandil y Ayacucho, aunque cabe aclarar que la cuenca continúa su extensión en ese sentido.

\subsubsection{Geología, geomorfología y suelos}

Las Sierras de Tandilia o Sierras Septentrionales, ubicadas en la parte central de la provincia de Buenos Aires, constituyen una provincia fisiográfica, formada por sierras, cerros, cerrilladas y lomas que sobresalen entre 50 y $250 \mathrm{~m}$ de la llanura pampeana (Teruggi y Kilmurray, 1975). Las sierras están formadas por cuarcitas cementadas subhorizontales y cubiertas por un delgado manto loéssico, donde se han desarrollado suelos muy profundos (Holmberg, 1972).

Dicho sistema se encuentra alineado en sentido NO-SE, abarcando unos $300 \mathrm{~km}$. desde las inmediaciones de Olavarría hasta Mar del Plata (Sala, 1975). El ancho varía desde $6 \mathrm{~km}$. en los extremos hasta $60 \mathrm{~km}$. en la parte central, donde se encuentra la ciudad de Tandil (Teruggi y Kilmurray, 1975).

En cuanto a las alturas, las mayores se hallan en las inmediaciones de la ciudad, alcanzando los $500 \mathrm{msnm}$. Hacia el Norte y Noreste presenta un piedemonte suave que se continúa en una extensa llanura, cruzada por valles de arroyos.

El cordón serrano emerge con dos pendientes, una hacia el NE, estrecha y algo abrupta, y la otra hacia el SO, ancha y suave. Estas pendientes regionales permitieron un drenaje consecuente hacia ambas vertientes, cuya erosión ha modificado la forma de las sierras y ha elaborado valles que las cortan respondiendo a la estructura original de bloques fallados.

Estratigráficamente, las rocas que conforman el cordón serrano de Tandilia son las más antiguas del territorio nacional, con edades entre 2.200 y 1.800 m.a., precámbrico (Teruggi y Kilmurray, 1975). Luego de la elevación de los bloques en el cenozoico, la erosión comenzó a actuar, sobre todo en zonas de debilidad, como zonas de fallas y aristas. 
El sistema de valles formados durante el ascenso serrano (Terciario a Cuaternario inferior) quedó luego sepultado bajo depósitos pampeanos y post-pampeanos, que cubrieron la región. Según Fidalgo (1983), los sedimentos pampeanos comprenden aquellos constituidos preferentemente por una fracción limo más abundante que las fracciones de arena y arcilla subordinadas, y se distribuyen en la mayor parte de la zona de estudio.

Los sedimentos post-pampeanos constituyen depósitos más modernos que los pampeanos y abarcan el Pleistoceno superior hasta la actualidad. Incluyen sedimentos de origen eólico, fluvial y lacustre donde predominan las fracciones arcilla y limo. Predominan en arroyos y lagunas de la zona, y presentan escaso espesor y poca extensión areal (Fidalgo et al., 1975; Fidalgo, 1983).

El sistema serrano se caracteriza por la presencia de dos unidades geológicas diferentes (Teruggi y Kilmurray, 1980). El basamento cristalino está compuesto por rocas ígneas plutónicas de edad Precámbrica con diferentes grados de metamorfismo, hidrolitológicamente consideradas rocas acuífugas; las mismas presentan fracturas que le dan un carácter de acuífero pobre. El cuerpo rocoso que aflora en las sierras constituye el hidroapoyo del sistema acuífero clástico sobrepuesto, se profundiza escalonadamente a partir de fracturas tensionales que, hacia la Cuenca del río Salado, hacen descender el basamento hasta profundidades mayores a los $6.000 \mathrm{~m}$. (Yrigoyen, 1975).

La segunda unidad la constituye una cubierta sedimentaria cenozoica, formada por conglomerados con clastos de gran tamaño en la zona próxima a las sierras, que van disminuyendo hacia la zona distal. Esta cubierta incluye sedimentos pampeanos de tipo limos loessoides, que lo convierten en un ambiente poroso clástico, dando lugar a un cuerpo acuífero que permite, dada su calidad y cantidad, la principal explotación del recurso hídrico subterráneo (Ruiz de Galarreta, 2006).

Regionalmente, pueden diferenciarse dentro del sistema serrano de Tandilia diversas unidades geomorfológicas de: sierras, piedemonte y llanura (Sala, 1975; Ruiz de Galarreta, 2006). El sector serrano se caracteriza por la presencia de sierras, cerros aislados y valles, con aparición de bloques elevados por fallas. En esta zona la topografía es abrupta y se presentan subcuencas con concentración de aguas superficiales. Sobre este sector serrano, se encuentra emplazado el Barrio Cerro Los Leones. El piedemonte, con una pendiente más suave, continúa a partir de las sierras con presencia de bloques de gran tamaño y conos aluviales. En esta zona el flujo es divergente, tanto el superficial como el subterráneo. Por último, la llanura se extiende hacia el NE en el ámbito extraserrano. Las pendientes son muy bajas, el drenaje es deficiente, y el flujo subterráneo y superficial se presenta mediante líneas de flujo subparalelas. 
Con respecto a los suelos de la región, la caracterización de los mismos publicada por INTA (1989) diferencia 3 subregiones. La primera de ellas, correspondiente a la morfología serrana, se caracteriza por afloramientos rocosos, pedregosidad en superficie y sectores con un delgado manto de loess, en donde predominan los Hapludoles líticos y Hapludoles petrocálcicos. La subregión pedemontana, que ocupa la mayor superficie de la cuenca, comprende las zonas de lomadas y los pequeños sectores de llanura, y está representada principalmente por Argiudoles típicos. La tercera zona, llamada de transición de los derrames, se extendería al Este hacia la localidad de Ayacucho.

\subsubsection{Hidrología}

En cuanto a las características hidrometeorológicas, el clima de la región es de tipo subhúmedo húmedo, mesotermal. Como se indica en la Tabla 1, la temperatura media anual en el período $1949-1986$ es de $13.6^{\circ} \mathrm{C}$.

Según Ruiz de Galarreta (2006), la evapotranspiración potencial (EVTp) ajustada siguiendo la metodología de Thornthwaite-Mather (1957) es 733 mm/año. Conociendo los valores mensuales de precipitación, la evapotranspiración potencial ajustada y los valores de la capacidad de almacenaje promedio de los suelos reconocidos en Tandil, fue determinada la evapotranspiración real como así también los déficits y excesos hídricos. El almacenaje de agua útil, de acuerdo al tipo de suelo y vegetación predominante, fue establecido en $150 \mathrm{~mm}$. Los resultados se indican en la Tabla 2, incluyendo las siguientes variables, cuyos valores se expresan en milímetros: $\mathrm{P}=$ precipitación media mensual; EVTp = evapotranspiración potencial; Ppaa = pérdida potencial de agua acumulada; Alm $=$ almacenamiento de agua útil; $\Delta$ Alm = variación del almacenamiento de agua; $\mathrm{EVTr}=$ evapotranspiración real.

Tabla 1. Temperatura media anual de Tandil, 1949-1986. (Fuente: Ruiz de Galarreta, 2006).

\begin{tabular}{c|cccccccccccccc} 
& $\mathrm{E}$ & $\mathrm{F}$ & $\mathrm{M}$ & $\mathrm{A}$ & $\mathrm{M}$ & $\mathrm{J}$ & $\mathrm{J}$ & $\mathrm{A}$ & $\mathrm{S}$ & $\mathrm{O}$ & $\mathrm{N}$ & $\mathrm{D}$ & Anual \\
\cline { 2 - 11 } Temperatura & 20.8 & 19.8 & 17.6 & 13.5 & 10.3 & 7.3 & 7 & 8.1 & 10.4 & 13.1 & 16.1 & 19.2 & 13.6
\end{tabular}


Tabla 2. Balance hídrico mensual 1900-2003. (Fuente: Ruiz de Galarreta, 2006).

\begin{tabular}{c|ccccccccccccc} 
Mes & E & F & M & A & M & J & J & A & S & O & N & D & Anual \\
\hline P & 85 & 79 & 100 & 69 & 70 & 49 & 42 & 45 & 61 & 85 & 83 & 78 & 846 \\
ETVp & 121 & 95 & 81 & 51 & 33 & 18 & 19 & 25 & 38 & 59 & 81 & 112 & 733 \\
P-EVTp & -36 & -16 & 19 & 18 & 37 & 31 & 23 & 20 & 23 & 26 & 2 & -34 & \\
Ppaa & -70 & -86 & & & & & & & & & & -34 & \\
Alm & 93 & 84 & 103 & 121 & 150 & 150 & 150 & 150 & 150 & 150 & 150 & 119 & \\
$\Delta$ Alm & -26 & -9 & 19 & 18 & 29 & 0 & 0 & 0 & 0 & 0 & 0 & -31 & \\
Déficit & 10 & 7 & & & & & & & & & & 3 & 20 \\
Excesos & & & & & 8 & 31 & 23 & 20 & 23 & 26 & 2 & & 133 \\
EVTr & 111 & 88 & 81 & 51 & 33 & 18 & 19 & 25 & 38 & 59 & 81 & 109 & 713
\end{tabular}

La representación gráfica del balance hídrico (Figura 24) muestra la diferencia entre los meses comprendidos de Mayo a Noviembre, en donde se producen excesos, de aquellos entre Diciembre y Marzo en donde ocurren los déficits de agua. Si bien este último período posee las mayores precipitaciones, se destaca la importancia del proceso de evapotranspiración en la regulación del balance hídrico.

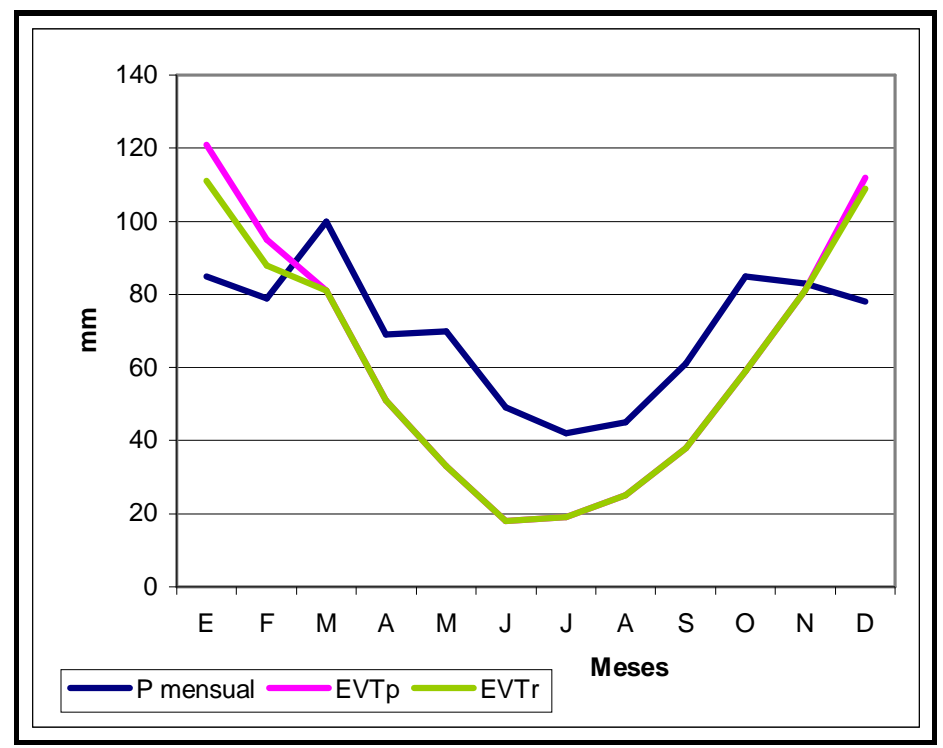

Figura 24. Balance hídrico 1900-2003. (Fuente: Ruiz de Galarreta, 2006)

En lo que respecta a los flujos de agua superficial y subterránea, la circulación de los mismos se ve condicionada por los rasgos geomorfológicos antes nombrados. En la zona serrana, el drenaje sigue la pendiente regional, con un diseño del tipo dendrítico y 
marcado control estructural. Existen pequeñas subcuencas que concentran las aguas superficiales. Al atravesar la ciudad, las subcuencas de los arroyos del Fuerte y Blanco, que actualmente se encuentran mayormente entubados, reciben aportes a partir de los colectores pluviales, con una importante contribución debido a la gran impermeabilización del área urbana. (Ruiz de Galarreta et al., 2007). En el sector periserrano, al noreste de la ciudad, el flujo se vuelve divergente, existiendo dispersión de los efluentes hídricos, de acuerdo con la morfología regional pedemontana. El Arroyo Langueyú se presenta en esta zona, sin recibir aportes de otros cursos de agua. En la llanura, se presentan las divisorias poco definidas y el flujo presenta líneas de flujo subparalelas.

Con respecto a las aguas subterráneas y de acuerdo a las características geológicas nombradas, se pueden diferenciar dos tipos de ambientes hidrolitológicos, que por su constitución, textura y estructura, se comportan en forma diferente respecto a la capacidad de recibir, almacenar y transportar el agua subterránea. Estas dos unidades corresponden a los medios fisurado y poroso clástico. El primero constituido por el basamento cristalino es una unidad acuífuga, que primariamente no almacena ni transmite agua, aunque posee permeabilidad secundaria por fisuración a través de fallas y diaclasas. Este aspecto es considerado clave en cuanto a la muy alta vulnerabilidad de dicho recurso frente a cargas contaminantes, debido a la elevada velocidad de circulación del agua en dichas fisuras (Ruiz de Galarreta y Banda Noriega, 2005).

La segunda unidad correspondiente al ambiente poroso clástico, está constituida por los sedimentos pampeanos y su permeabilidad es primaria. En este medio poroso clástico se ubica, como se dijo anteriormente, el sistema acuífero principal explotado para el abastecimiento humano por parte de toda la población tanto rural como urbana.

A partir del relevamiento hidrodinámico efectuado en el marco del proyecto "Diagnóstico integral del Recurso Hídrico en el partido de Tandil. Pautas para su gestión sustentable", en que la autora de esta investigación ha participado, se confeccionó un mapa hidrodinámico base (Figura 25).

El análisis hidrodinámico regional se basa en el trabajo de Ruiz de Galarreta et al. (2007), que indica que el sentido del flujo subterráneo regional es hacia el NE, en relación a las características superficiales antes descriptas. En general, presenta superficies equipotenciales radiales a planas y, al igual que en el ámbito superficial, con divisorias indefinidas a medida que se aleja del sector serrano.

En el sector serrano, al sur de la cuenca, se produce concentración del escurrimiento, con influencia de las aguas subterráneas en relación a los cursos superficiales como el arroyo Blanco y del Fuerte. En la zona extraserrana, se observa una 
leve dispersión del flujo freático, presentando una morfología en abanico con tendencia a plana. El curso del arroyo Langueyú no recibe aportes laterales y su relación con las aguas subterráneas es de escasa magnitud, aunque se presentan anomalías en la hidrodinámica regional, cambiando la relación de influencia con los arroyos, debido a cambios en las condiciones hidráulicas, geológicas, o en zonas de intensa explotación del acuífero. Donde el régimen de los arroyos se vuelve permanente, se produce el aporte de caudal básico por parte de las aguas subterráneas.

El mismo trabajo detalla que la profundidad de los niveles freáticos es variable aunque en general, en marzo de 2007, no superó los 10 metros en la mayor parte de la cuenca, alcanzando los mayores valores en el sector pedemontano y los menores hacia el norte. La zona de recarga, que es autóctona por precipitaciones, se ubica en las zonas altas, mientas que la descarga regional lo hace hacia la zona deprimida del río Salado y, localmente, en los cursos y afluentes principales del arroyo Langueyú.

El espesor saturado del acuífero en la zona serrana, correspondiente al medio poroso clástico, es muy variable, en función de la magnitud de la cubierta sedimentaria sobre los bloques fallados de rocas. En cambio, en el ámbito extraserrano, se presentan espesores sedimentarios que varían entre 55 y 78 metros de acuerdo a los perfiles litológicos de los pozos de abastecimiento de agua corriente pertenecientes al Municipio, con tendencia a profundizarse hacia el NE.

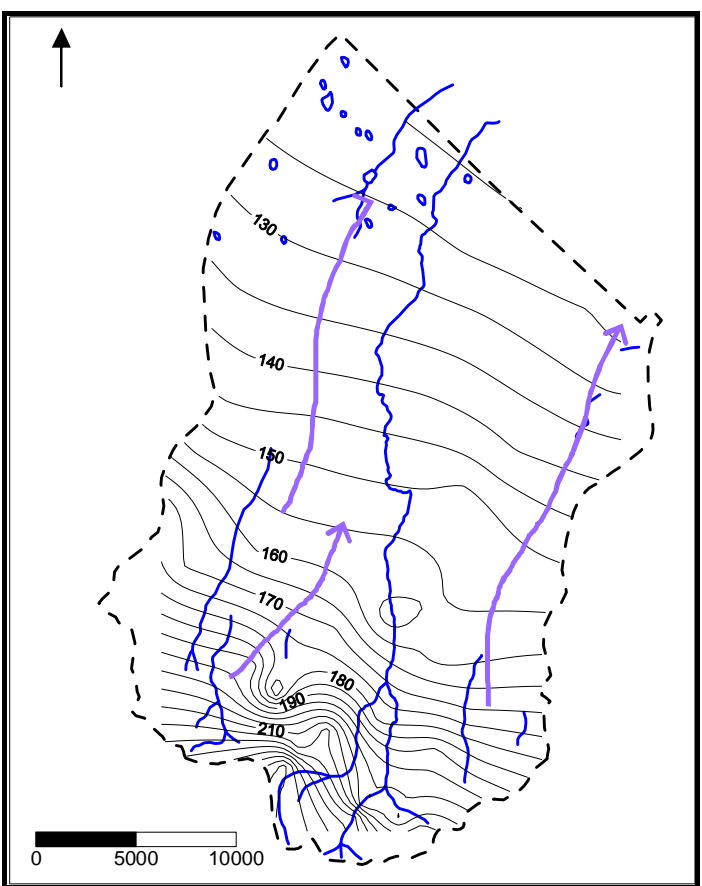

Figura 25. Mapa equipotencial

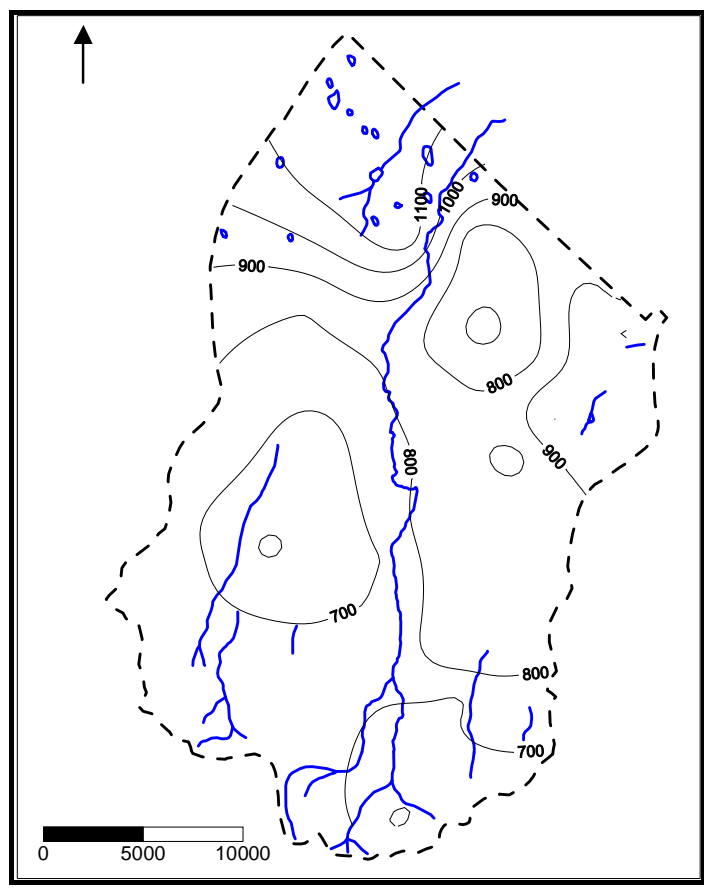

Figura 26. Mapa de isoconductividades

Cuenca del arroyo Langueyú (Marzo 2007). Fuente: Ruiz de Galarreta et al., 2007 
Además de las condiciones hidrodinámicas, se ha caracterizado la hidroquímica subterránea. Se midió la conductividad eléctrica, obteniéndose contenidos salinos entre 700 y $800 \mu \mathrm{mho} / \mathrm{cm}$ en la zona serrana y pedemontana, que se incrementan hacia la llanura distal alcanzando y superando los $1000 \mu \mathrm{mho} / \mathrm{cm}$, como se presenta en la Figura 26.

Según la investigación de Barranquero et al. (2008b), en la que participó el director de esta Tesis de Maestría, las aguas subterráneas se clasifican, de acuerdo a su composición química, como bicarbonatadas sódicas y pueden considerarse jóvenes por su bajo contenido salino y el predominio de este anión. En el mismo trabajo, se indican las concentraciones de los iones mayoritarios (Tabla 1).

Tabla 3. Características físico-químicas de las aguas subterráneas en la Cuenca del arroyo Langueyú. (Fuente: Barranquero et al., 2008b)

\begin{tabular}{c|c} 
Iones en mg/l & Promedio \\
\hline Dureza $\left(\mathrm{mg} / \mathrm{CO}_{3} \mathrm{Ca}\right)$ & 179 \\
$\mathrm{pH}$ & 7.8 \\
$\mathrm{CE}(\mu \mathrm{s} / \mathrm{cm})$ & 797.4 \\
$\mathrm{HCO}_{3}$ & 478.8 \\
$\mathrm{Cl}$ & 31.7 \\
$\mathrm{NO}_{3}$ & 31.7 \\
$\mathrm{SO}_{4}$ & 13.3 \\
$\mathrm{Ca}$ & 36.4 \\
$\mathrm{Na}$ & 195.7 \\
$\mathrm{Mg}$ & 20.9 \\
$\mathrm{~K}$ & 13.8
\end{tabular}

\subsection{Análisis hidrológico en el Barrio Cerro Los Leones}

\subsubsection{Balance hídrico del período de estudio}

El balance hídrico realizado para el período de estudio abarcó desde septiembre de 2007 a agosto de 2008, no obstante para ajustar el almacenaje de agua en el suelo, fue iniciado en 2005. En el Anexo III se presenta el balance seriado completo desde 2005 a 2008.

La precipitación anual para el lapso alcanzó los $637 \mathrm{~mm}$, por debajo de la media histórica de $846 \mathrm{~mm}$. La Figura 27 compara las precipitaciones medias mensuales del período 1900-2003 con las precipitaciones mensuales para el lapso de estudio, obtenidas a partir de los valores diarios de la Estación Tandil Aeródromo, del Servicio Meteorológico 
Nacional. Puede observarse claramente la escasez de lluvias a lo largo de la mayor parte del año de estudio, excepto en tres ocasiones, una al inicio, en septiembre - octubre de 2007, otra en marzo de 2008 y la tercera en julio - agosto de 2008.

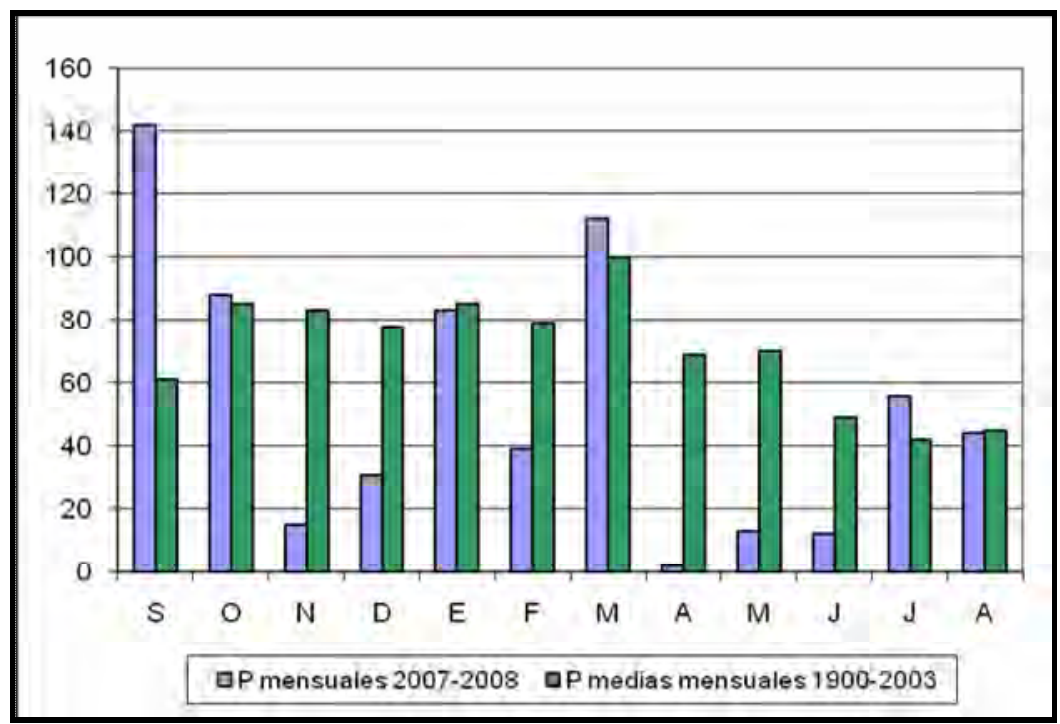

Figura 27. Precipitaciones mensuales históricas y del período de estudio.

Los resultados del balance hídrico para el año de interés (Tabla 4) indicaron que la EVTp fue de $733 \mathrm{~mm}$, superando ampliamente a la precipitación, y la EVTr presentó un valor de $562 \mathrm{~mm}$. Como se puede observar que en siete de los doce meses considerados existieron importantes déficits producto de los bajos ingresos por precipitación.

Tabla 4. Balance hídrico para el período Septiembre 2007 a Agosto 2008.

\begin{tabular}{c|cccc|cccccccc|c} 
Año & \multicolumn{5}{|c|}{2007} & \multicolumn{7}{|c|}{2008} & \\
\hline Mes & $\mathrm{S}$ & $\mathrm{O}$ & $\mathrm{N}$ & $\mathrm{D}$ & $\mathrm{E}$ & $\mathrm{F}$ & $\mathrm{M}$ & $\mathrm{A}$ & $\mathrm{M}$ & $\mathrm{J}$ & $\mathrm{J}$ & $\mathrm{A}$ & Total \\
\hline $\mathrm{P}$ & 142 & 88 & 15 & 31 & 83 & 39 & 112 & 2 & 13 & 12 & 56 & 44 & 637 \\
EVTp & 38 & 59 & 81 & 112 & 121 & 95 & 81 & 51 & 33 & 18 & 19 & 25 & 733 \\
P-EVTp & 104 & 29 & -66 & -81 & -38 & -56 & 31 & -49 & -20 & -6 & 37 & 19 & \\
Ppaa & & & -66 & -147 & -185 & -241 & -134 & -183 & -203 & -209 & -106 & -71 & \\
Alm & 150 & 150 & 96 & 55 & 43 & 29 & 60 & 43 & 38 & 36 & 73 & 92 & \\
$\Delta$ Alm & 28 & 0 & -54 & -41 & -12 & -14 & 31 & -17 & -5 & -2 & 37 & 19 & \\
Déficit & & & 12 & 40 & 26 & 42 & & 32 & 15 & 4 & & & 171 \\
Excesos & 75 & 29 & & & & & & & & & & & 104 \\
EVTr & 38 & 59 & 69 & 72 & 95 & 53 & 81 & 19 & 18 & 14 & 19 & 25 & 562
\end{tabular}

La Figura 28 presenta el gráfico del balance donde se visualiza claramente las relaciones entre las variables P, EVTp y EVTr para este período de bajas precipitaciones y por ende altos déficit. 


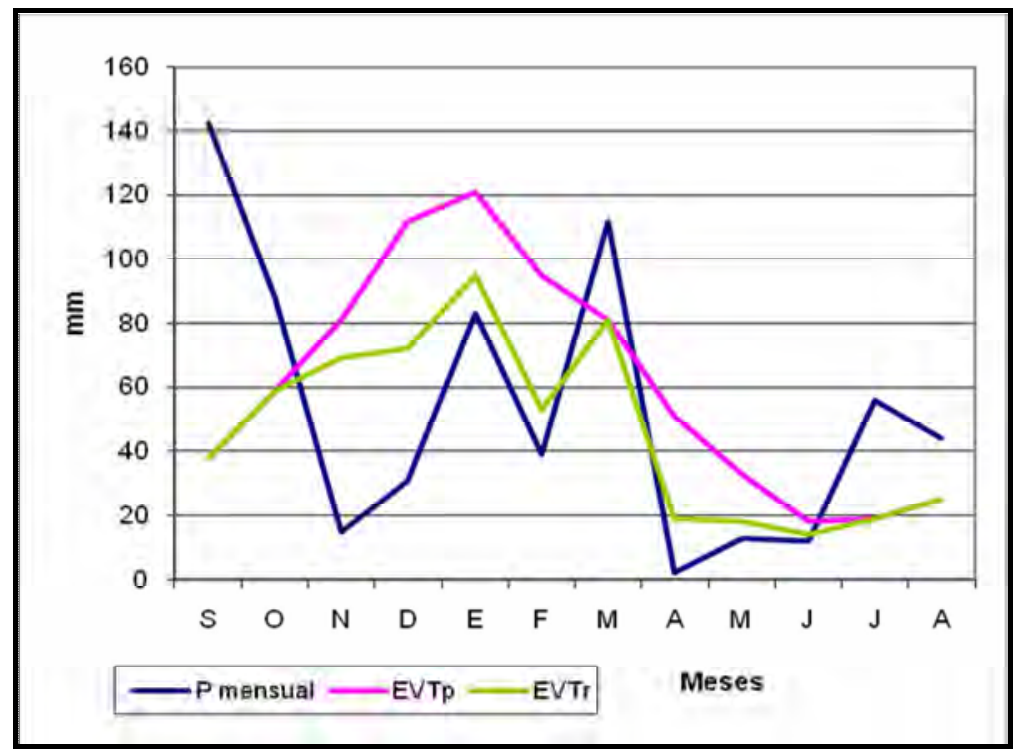

Figura 28. Balance hídrico para el período Septiembre 2007 a Agosto 2008

La comparación con los datos medios presentados en el ítem 3.1.2, permitió observar que el período de estudio se caracterizó por la escasez de precipitaciones con respeto a los establecidos para el lapso 1900-2003. Asimismo, la ocurrencia de déficits desde noviembre de 2007 a junio de 2008 (exceptuando el mes de marzo), superó ampliamente los déficits medios, sucedidos en el trimestre noviembre, diciembre y enero. El déficit total del período fue de $171 \mathrm{~mm}$, siendo mucho mayor que el valor medio. Los excesos se produjeron únicamente en los primeros meses, septiembre y octubre de 2007, y totalizaron $104 \mathrm{~mm}$, por debajo del valor medio de $133 \mathrm{~mm}$, acumulados de mayo a noviembre.

Como se indica a continuación, en el ítem 3.2.3 Hidrodinámica subterránea, este período de escasez de precipitaciones impactó sobre los niveles estáticos, provocando su descenso en los meses de déficit hídrico.

\subsubsection{Red de medición y muestreo}

Para la realización de los censos y muestreos, se seleccionó una red de 15 pozos ubicados en domicilios particulares, más 3 adicionales correspondientes a establecimientos del barrio, siendo los sistemas de extracción bombas de mano, molinos o equipos eléctricos como bombas centrífugas, sumergibles o bombeadores. La ubicación de estos sitios se detalla en la Tabla 5 y en la Figura 29. 
Tabla 5. Ubicación de los sitios de medición.

\begin{tabular}{|c|c|c|}
\hline \multirow[t]{2}{*}{$\begin{array}{l}\text { Sitio } \\
\mathrm{N}^{\mathrm{o}}\end{array}$} & \multicolumn{2}{|c|}{$\begin{array}{c}\text { Coordenadas } \\
\text { Gauss Kruger (m) }\end{array}$} \\
\hline & $\mathrm{X}$ & $\mathrm{Y}$ \\
\hline 1 & 5.571 .095 & 5.870 .082 \\
\hline 2 & 5.570 .984 & 5.870 .511 \\
\hline 3 & 5.571 .575 & 5.870 .570 \\
\hline 4 & 5.571 .350 & 5.870 .107 \\
\hline 5 & 5.571 .410 & 5.869 .991 \\
\hline 6 & 5.571 .111 & 5.870 .190 \\
\hline 7 & 5.570 .745 & 5.870 .183 \\
\hline 8 & 5.570 .496 & 5.870 .212 \\
\hline 9 & 5.572 .008 & 5.871 .368 \\
\hline 10 & 5.571 .526 & 5.870 .378 \\
\hline 11 & 5.571 .500 & 5.870 .003 \\
\hline 12 & 5.570 .681 & 5.870 .416 \\
\hline 13 & 5.570 .339 & 5.870 .016 \\
\hline 14 & 5.570 .930 & 5.870 .669 \\
\hline 15 & 5.571 .165 & 5.870 .897 \\
\hline 16 & 5.570 .550 & 5.870 .253 \\
\hline 17 & 5.570 .659 & 5.870 .232 \\
\hline 18 & 5.572 .311 & 5.870 .568 \\
\hline
\end{tabular}

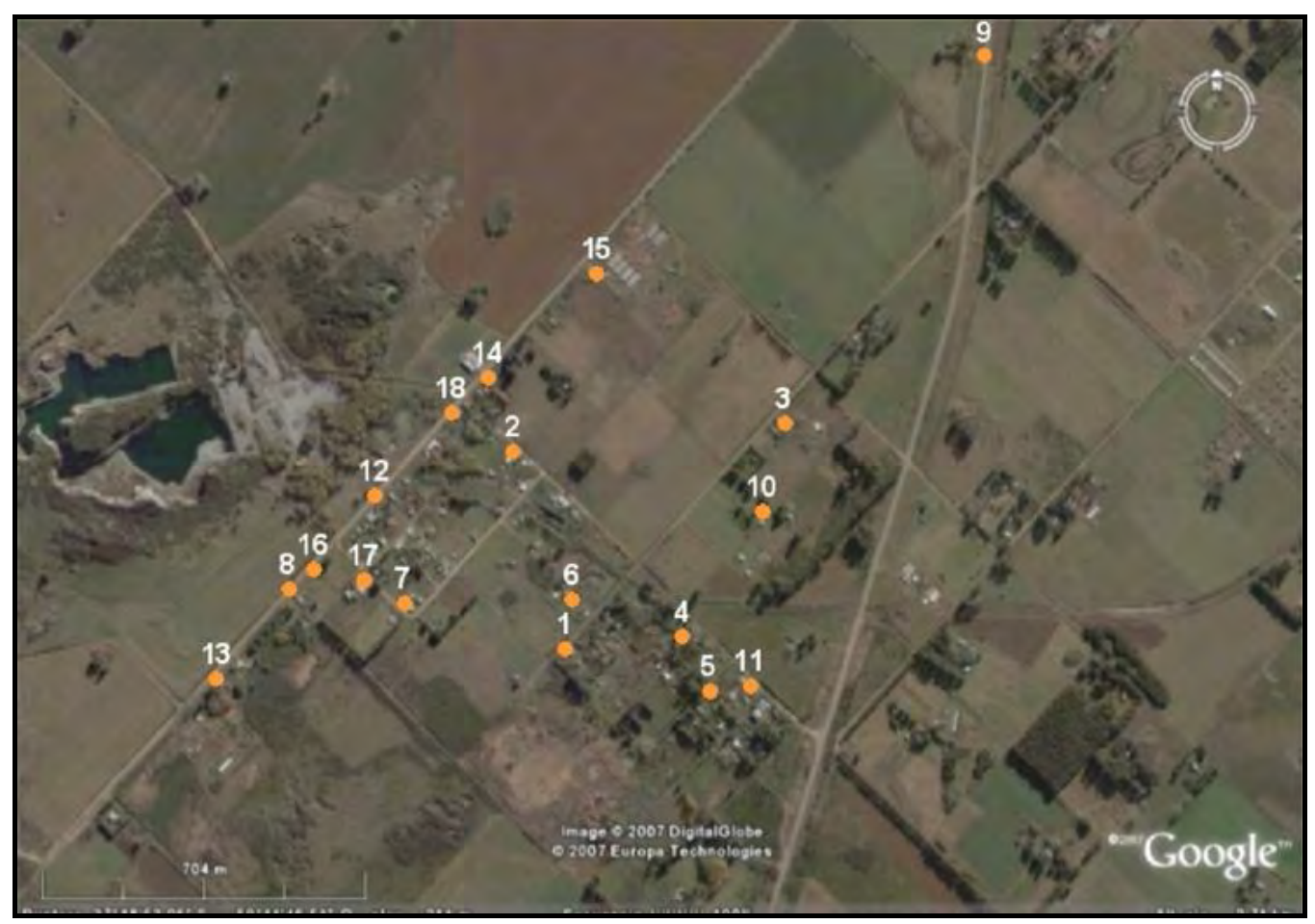

Figura 29. Red de pozos de medición y muestreo. 


\subsubsection{Hidrodinámica subterránea}

De las 18 perforaciones incluidas en la red de muestreo, sólo se realizaron las mediciones freatimétricas en 12 de ellas, debido a que el resto presentó dificultades u obstrucciones en las cañerías o bombas.

Además, en las diferentes campañas, no pudieron censarse todos los sitios, debido a no encontrarse los habitantes de las respectivas viviendas en reiteradas ocasiones. Tal es el caso de la perforación $\mathrm{N}^{0} 7$, donde sólo se pudo acceder a la medición en el primer censo, luego del cual la vivienda se encontró desocupada.

En general, las perforaciones del área de estudio alcanzaron profundidades entre 8 y 20 metros, siendo la mayoría de 12 metros. Cabe aclarar que estos datos no fueron medidos sino informados por los propietarios a través de las encuestas realizadas.

La Tabla 6 presenta los datos de altura de boca de pozos así como las cotas topográficas de cada sitio. Con esta información y los niveles freáticos medidos, se calcularon los niveles piezométricos.

Tabla 6. Cotas topográficas de los sitios de medición.

\begin{tabular}{c|cc} 
Sitio $\mathrm{N}^{\mathrm{o}}$ & $\begin{array}{c}\text { Altura de boca } \\
\text { de pozo }(\mathrm{m})\end{array}$ & $\begin{array}{c}\text { Cota de pozo } \\
(\mathrm{m})\end{array}$ \\
\hline 2 & 0,47 & 217,5 \\
4 & 0,39 & 221,3 \\
5 & 0,32 & 221,7 \\
6 & 0,47 & 234,8 \\
7 & 0,1 & 223,1 \\
8 & 0,43 & 226,3 \\
9 & 0,28 & 204,5 \\
10 & 0,6 & 211,4 \\
11 & 0,6 & 224,5 \\
12 & 0,12 & 218,5 \\
13 & 0,12 & 230,1 \\
15 & 0,57 & 207,3
\end{tabular}

Con el objetivo de cubrir un ciclo hidrológico completo, se efectuaron cinco censos con frecuencia trimestral, dando inicio y cierre en el mismo mes. En ellos se relevaron los datos de profundidad del nivel freático, desde la boca del pozo. Las fechas fueron: Septiembre 2007 - Diciembre 2007 - Marzo 2008 - Junio 2008 - Septiembre 2008. 
Los resultados para los cinco censos se indican en la Tabla 7, que presenta las profundidades del nivel freático medida en metros, desde la boca de pozo, donde SD significa sin datos del nivel freático.

Tabla 7. Profundidad del nivel freático a lo largo del período.

\begin{tabular}{c|ccccc} 
Sitio N & Sep 07 & Dic 07 & Mar 08 & Jun 08 & Sep 08 \\
\hline 2 & 13,57 & 9,42 & 9,6 & 10,05 & 10,25 \\
4 & 5,14 & 4,34 & 5,15 & 5,78 & 5,8 \\
5 & 3,45 & 4,16 & 4,73 & 5,36 & 5,27 \\
6 & 8,79 & 8,95 & SD & 12,7 & 10,15 \\
7 & 22 & SD & SD & SD & SD \\
8 & 13,5 & 11,33 & 11,66 & SD & SD \\
9 & 4,05 & 3,7 & SD & 4,4 & SD \\
10 & 6,57 & 6,25 & 6,69 & 7,2 & 7,44 \\
11 & 7,6 & SD & 8,23 & 8,56 & 8,93 \\
12 & 9,8 & 9,3 & SD & 9,59 & 9,67 \\
13 & 5,2 & 4,95 & 4,5 & 5,39 & 5 \\
15 & 8,2 & 7,81 & 8,24 & 8,8 & 9,1
\end{tabular}

El análisis de las variaciones de los niveles freáticos a lo largo del período de estudio indicó que las menores profundidades se encontraron en los censos de septiembre y, especialmente, diciembre de 2007. Posteriormente, comenzaron a detectarse incrementos en las mismas, alcanzando los mayores valores para fin del ciclo.

Es importante el conocimiento de la profundidad del nivel freático, debido a que indica el espesor de la zona no saturada, la cual constituye la zona de disposición de los efluentes domiciliarios en pozos absorbentes y letrinas.

Para la interpretación de estos resultados y su relación con otras variables del balance hídrico, se construyeron mapas de isoprofundidades del nivel freático, para diciembre de 2007 y septiembre de 2008, que corresponden a los momentos de menor y mayor profundidad respectivamente. Ambos se presentan en las Figuras 30 y 31 en las cuales se observó la mayor profundidad del nivel en la zona más densamente poblada, producto de la explotación del recurso a través del bombeo. Asimismo, se destacó el incremento de dicha profundidad hacia septiembre de 2008, en relación a la escasez de precipitaciones en el período y los déficits hídricos producidos. 


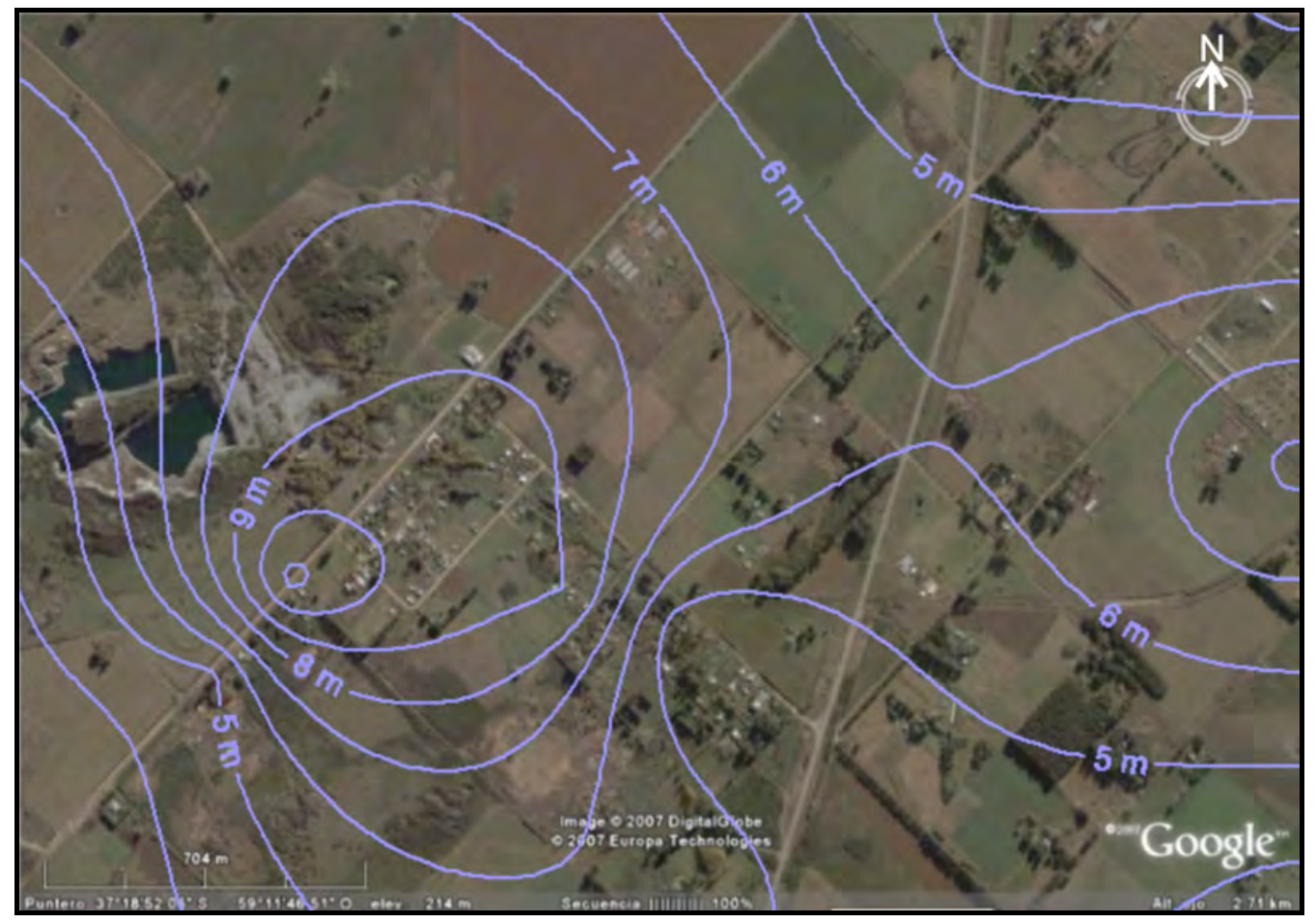

Figura 30. Mapa de isoprofundidades del nivel freático para diciembre 2007.

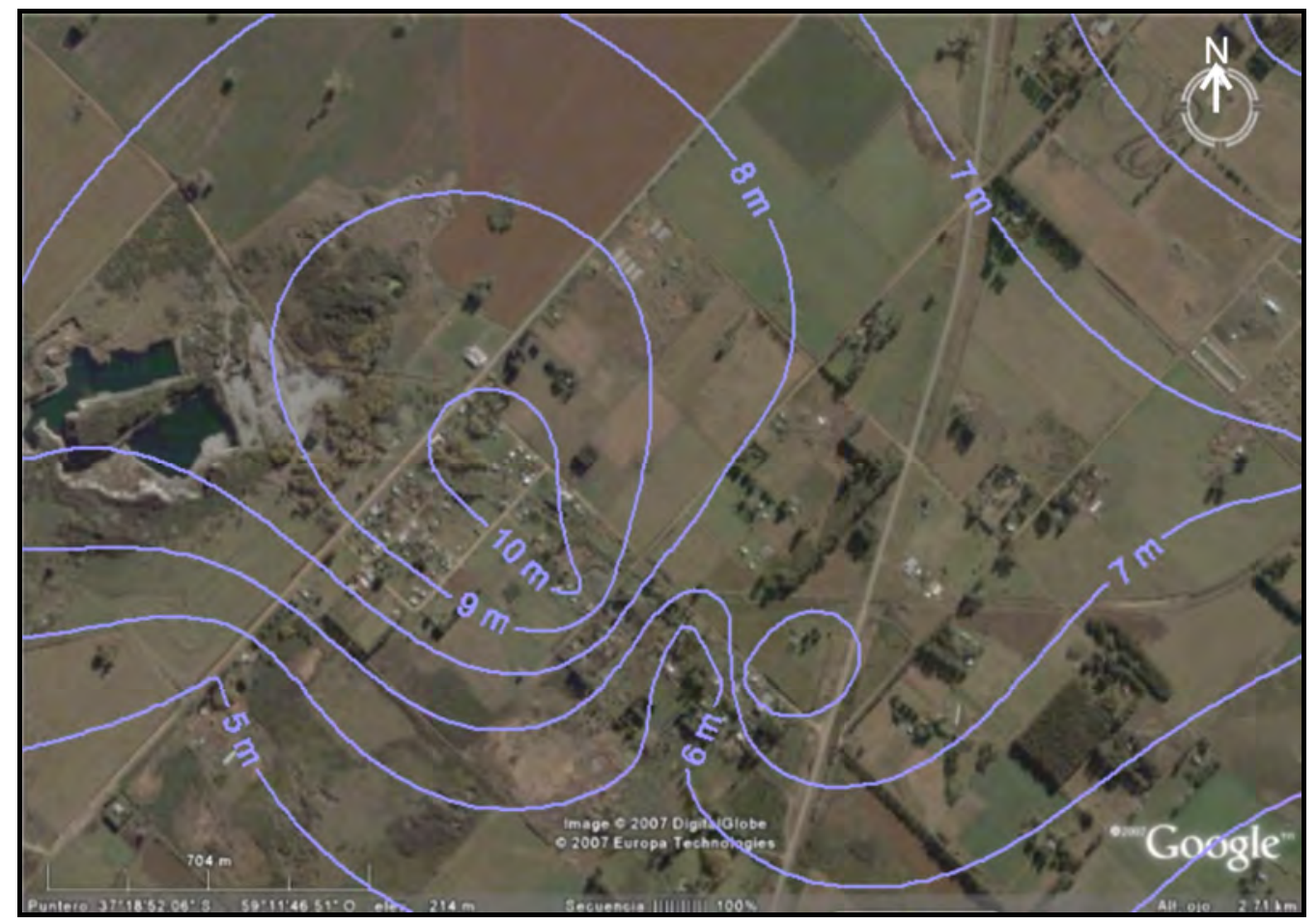

Figura 31. Mapa de isoprofundidades del nivel freático para septiembre 2008.

En la Figura 32 se presenta el descenso del nivel freático entre ambas fechas (diciembre 2007 y septiembre 2008). Pudo observarse que en la zona alta del barrio, hacia 
el SO, los descensos oscilan entre 0.4 y $0.8 \mathrm{~m}$, mientras que hacia el $\mathrm{N}$ y $\mathrm{NE}$ la variación fue mayor, alcanzando valores de $1.4 \mathrm{~m}$ de diferencia entre ambas fechas.

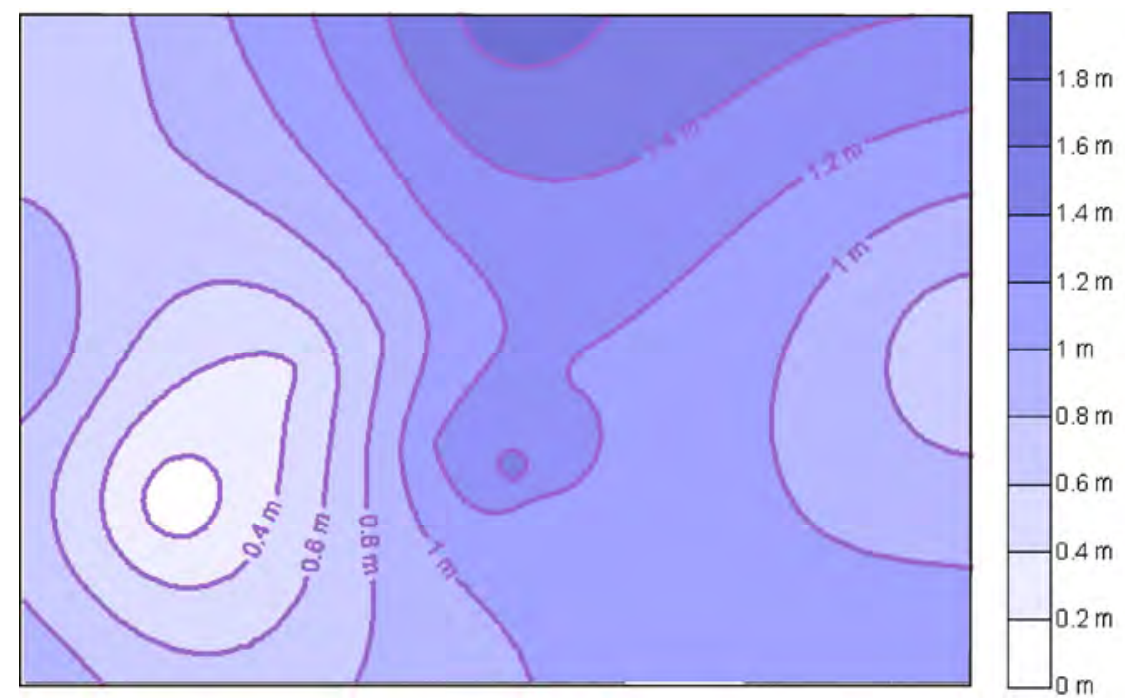

Figura 32. Descenso de los niveles desde diciembre 2007 a septiembre 2008.

El seguimiento realizado durante el año demostró la existencia de variaciones de los niveles freáticos, aunque no modificaron sustancialmente el sistema de flujo en la zona.

Para facilitar la interpretación de la hidrodinámica, se indican en la Tabla 8 los niveles piezométricos (en metros) para cada censo, y los valores estadísticos, correspondientes a la media, máximo, mínimo, desvío estándar (DE) y coeficiente de variación $(\mathrm{CV})$.

Tabla 8. Niveles piezométricos medidos y análisis estadístico por perforación.

\begin{tabular}{c|cccccccccc}
$N^{o}$ & Sep 07 & Dic 07 & Mar 08 & Jun 08 & Sep 08 & Promedio & Máximo & Mínimo & DE & CV\% \\
\cline { 2 - 10 } 2 & 204,4 & 208,55 & 208,37 & 207,92 & 207,72 & 207,39 & 208,55 & 204,4 & 1,71 & 0,82 \\
4 & 216,55 & 217,35 & 216,54 & 215,91 & 215,89 & 216,44 & 217,35 & 215,89 & 0,60 & 0,28 \\
5 & 218,57 & 217,86 & 217,29 & 216,66 & 216,75 & 217,42 & 218,57 & 216,66 & 0,80 & 0,37 \\
6 & 226,48 & 226,32 & SD & 222,57 & 225,12 & 225,12 & 226,48 & 222,57 & 1,81 & 0,80 \\
7 & 201,2 & SD & SD & SD & SD & --- & --- & --- & --- & --- \\
8 & 213,23 & 215,4 & 215,07 & SD & SD & 214,56 & 215,4 & 213,23 & 1,17 & 0,54 \\
9 & 200,73 & 201,08 & SD & 200,38 & SD & 200,73 & 201,08 & 200,38 & 0,35 & 0,17 \\
10 & 205,43 & 205,75 & 205,31 & 204,8 & 204,56 & 205,17 & 205,75 & 204,56 & 0,48 & 0,24 \\
11 & 217,5 & SD & 216,87 & 216,54 & 216,17 & 216,77 & 217,5 & 216,17 & 0,56 & 0,26 \\
12 & 208,82 & 209,32 & SD & 209,03 & 208,95 & 209,03 & 209,32 & 208,82 & 0,21 & 0,10 \\
13 & 225,02 & 225,27 & 225,72 & 224,83 & 225,22 & 225,21 & 225,72 & 224,83 & 0,33 & 0,15 \\
15 & 199,67 & 200,06 & 199,63 & 199,07 & 198,77 & 199,44 & 200,06 & 198,77 & 0,51 & 0,26
\end{tabular}


Los niveles medios del período, presentaron valores desde $199.44 \mathrm{~m}$ en la perforación $\mathrm{N}^{\mathrm{o}} 15$, ubicada al NE del área en la zona pedemontana, hasta $225.21 \mathrm{~m}$ en la $\mathrm{N}^{0} 13$, situada en la zona serrana y de mayor altura (Figura 29). Los máximos alcanzados corresponden a las perforaciones $\mathrm{N}^{\mathrm{o}} 6$ y 13 , superando $\operatorname{los} 225 \mathrm{~m}$, mientras que los mínimos fueron de 198.77 m en la $\mathrm{N}^{\circ} 15$ y 200.38 m en la $\mathrm{N}^{\circ}$ 9, ambas ubicadas al NE del área. El desvío estándar y el coeficiente de variación presentan en general valores bajos.

A partir de las mediciones colectadas en los censos en la zona en estudio, se confeccionaron mapas equipotenciales para cada fecha. Los resultados para septiembre de 2007 se presentan en la Figura 33. En esa fecha, la profundidad del nivel freático osciló entre $3.5 \mathrm{~m}$ y $13.6 \mathrm{~m}$, aunque en una perforación alcanzó $22 \mathrm{~m}$. Los niveles estáticos, variaron entre $199.6 \mathrm{~m}$ y $226.5 \mathrm{~m}$. Cabe destacar que la perforación $\mathrm{N}^{\mathrm{o}} 7$, cuyo nivel freático en esta fecha alcanzó los $22 \mathrm{~m}$ de profundidad, no pudo ser censada posteriormente, debido al traslado de los propietarios de la vivienda.

Analizando el escurrimiento subterráneo local, se verificó que el agua fluye desde la zona serrana que rodea al barrio, hacia la periserrana, con un flujo radial convergente focalizado. A partir de allí, el sentido de flujo coincidió con el regional enunciado anteriormente. Existe una diferencia de $30 \mathrm{~m}$ entre el lugar más elevado y el más bajo del barrio, por lo cual las mayores profundidades corresponden a las perforaciones ubicadas al SO, en la zona más alta del barrio, descendiendo hacia el sector periserrano al NE.

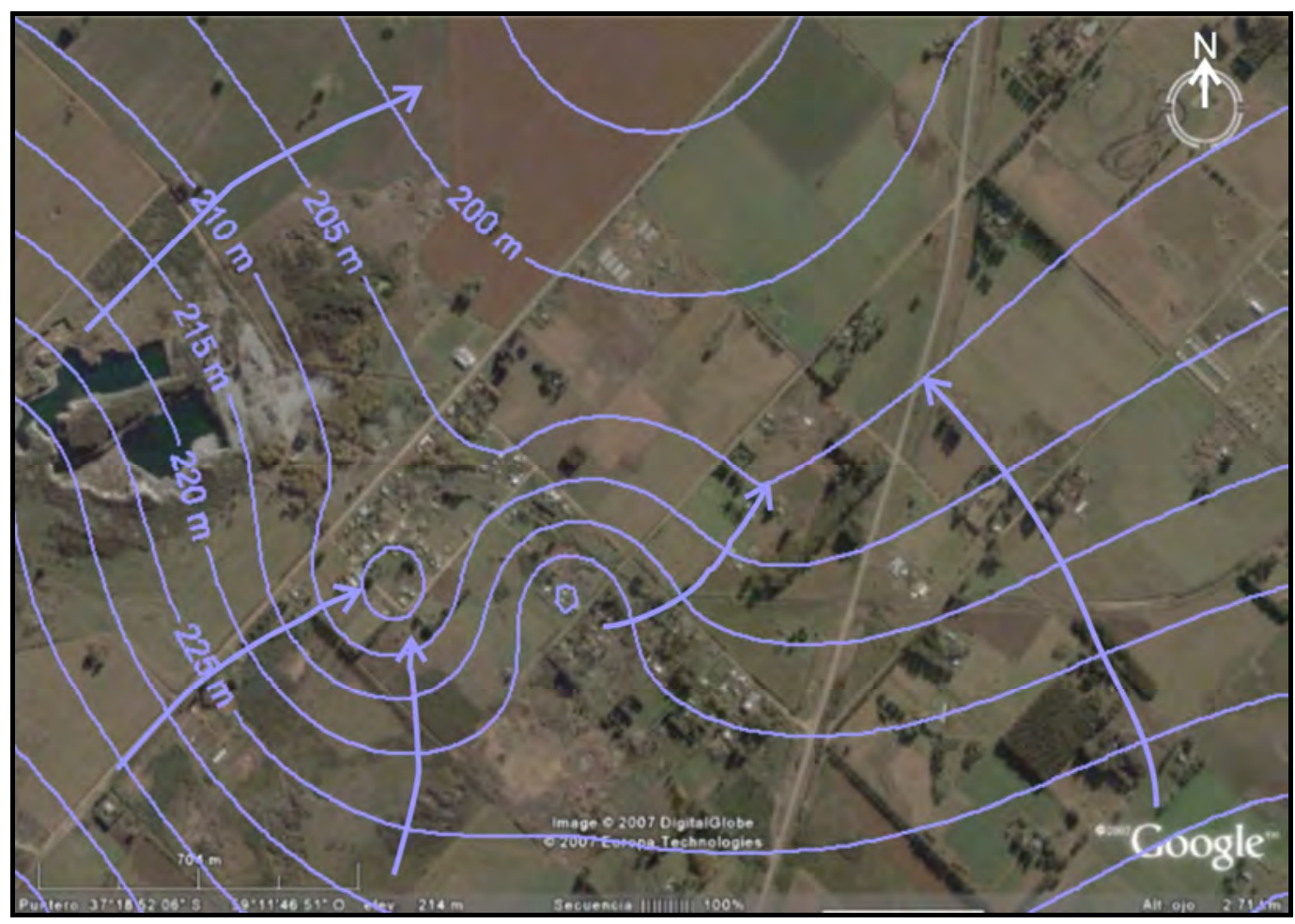

Figura 33. Mapa equipotencial de la zona de estudio, para septiembre de 2007. 
En las posteriores mediciones se corroboró el flujo subterráneo local, aunque se presentaron variaciones leves, de acuerdo a la ocurrencia de precipitaciones y la variación de la evapotranspiración a lo largo del período. Por tal motivo, se evitó la presentación de mapas equipotenciales de similares características a la Figura 33.

En el segundo censo, realizado en diciembre de 2007, los niveles freáticos en general mostraron leves ascensos, con profundidades entre 4.1 y 11.3 metros. Este incremento se relacionó con el período previo de excesos hídricos.

En marzo de 2008, los niveles estáticos variaron entre 199.6 y 225.7 metros, y presentaron descensos respecto a diciembre 2007. Cabe destacar la dificultad en la obtención de la información en este censo, encontrándose cuatro perforaciones sin posibilidad de ser medidas.

En junio la profundidad de la superficie freática osciló entre 4.4 y 12.7 metros, obteniéndose niveles estáticos entre 199 y 224.8 metros. Se presentaron nuevamente descensos, que continuaron observándose y se acrecentaron, en muchos casos, en la medición posterior correspondiente al cierre del ciclo. Esta situación de bajas en los niveles, obedeció al período de déficit hídrico que se extendió durante 8 meses.

Continuando con el análisis de la hidrodinámica local, se han seleccionado tres perforaciones, $\mathrm{N}^{\mathrm{o}} 4,10$ y 15 , las cuales fueron censadas en todas las oportunidades y además se consideraron representativas al no encontrarse afectadas por bombeo en los momentos de medición. Se graficaron las variaciones de los niveles en cada una (Figuras 34,36 y 37). Se observó un comportamiento similar en ellas, con un incremento del nivel piezométrico inicial hacia el mes de diciembre. Esta situación obedeció a las precipitaciones acaecidas en los meses previos (septiembre y octubre de 2007) y al exceso hídrico ocurrido. Las variaciones de los niveles y su relación con las precipitaciones se presentan en la Figura 35, basada en la perforación $\mathrm{N}^{\mathrm{o}}$ 4, y la 38 para el sitio de medición No 15 .

A partir de allí, se registraron descensos en las tres perforaciones, en forma paulatina, hasta alcanzar el mínimo en septiembre de 2008, muy por debajo del valor registrado en el mismo mes del año anterior. De acuerdo a los resultados del balance hídrico, presentados previamente en el ítem 3.2.1, se observó la relación directa entre los déficits del lapso comprendido entre noviembre de 2007 y junio de 2008, con los descensos en los niveles freáticos durante el mismo período. 


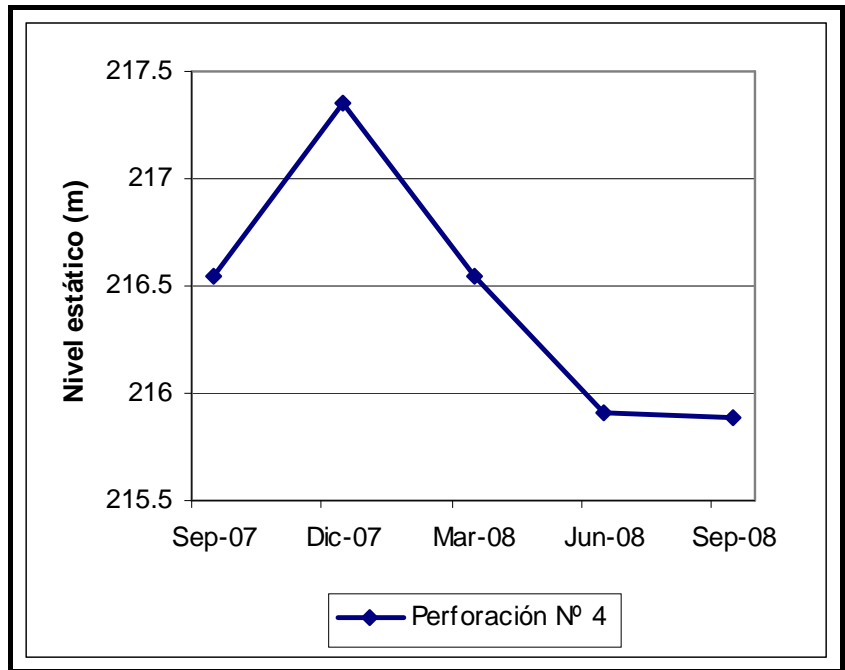

Figura 34. Variación del nivel piezométrico en la perforación $\mathrm{N}^{\circ} 4$.

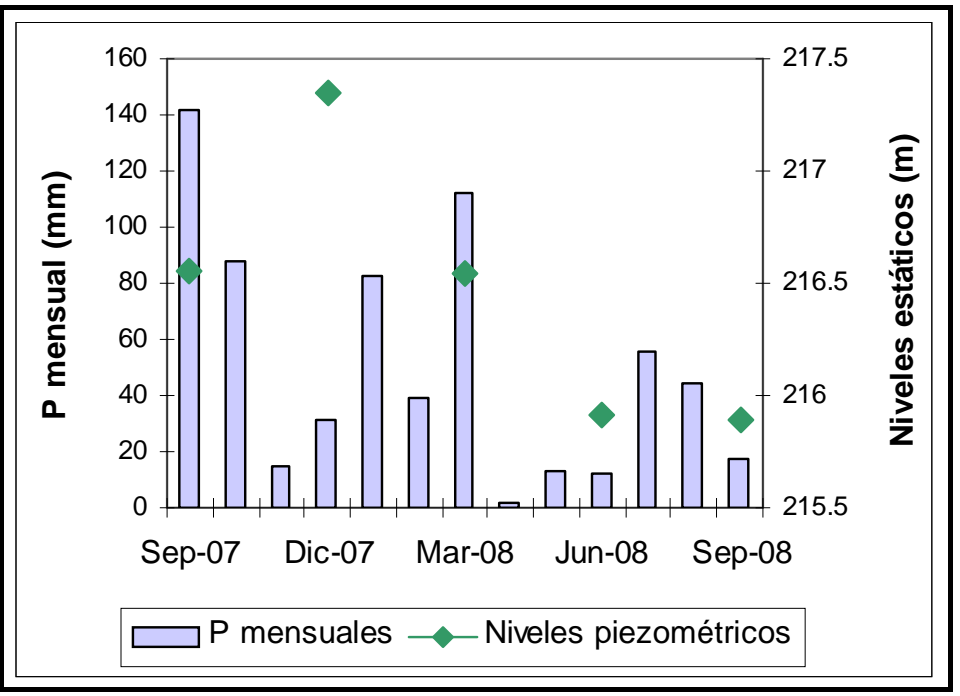

Figura 35. Variación del nivel respecto a las precipitaciones en la perforación $\mathrm{N}^{\circ} 4$.

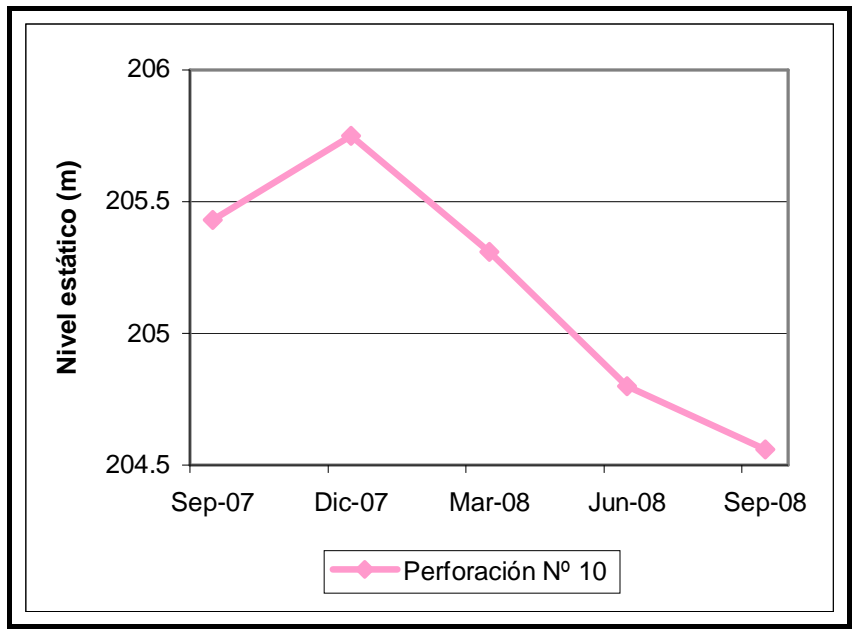

Figura 36. Variación del nivel piezométrico en la perforación $\mathrm{N}^{\circ} 10$. 


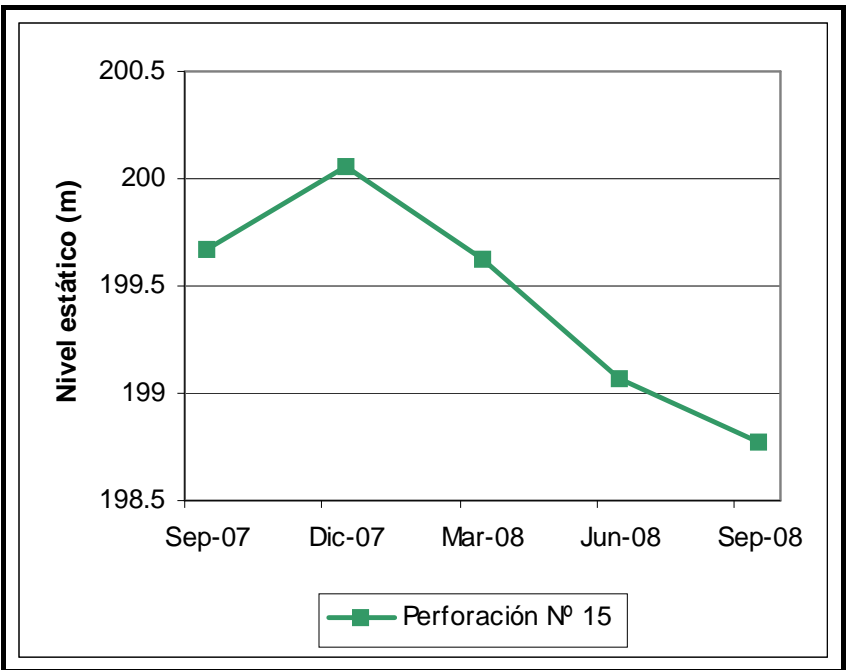

Figura 37. Variación del nivel piezométrico en la perforación $\mathrm{N}^{\circ} 15$.

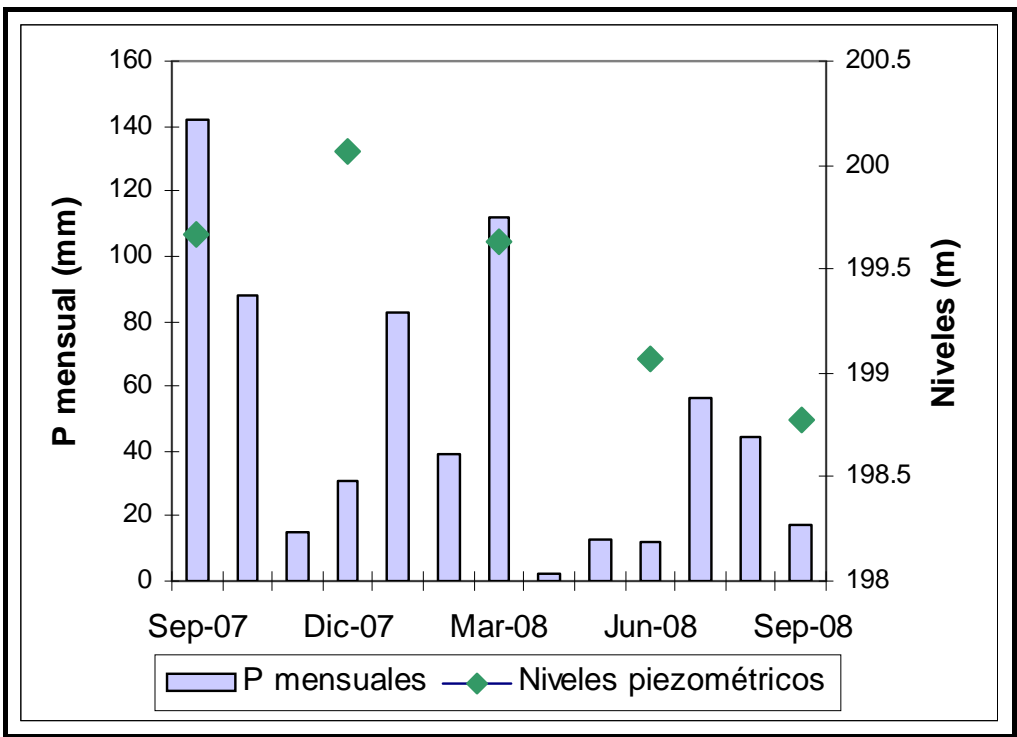

Figura 38. Variación del nivel respecto a las precipitaciones en la perforación $\mathrm{N}^{\mathrm{0}} 15$.

A partir del análisis, pudo concluirse que la dinámica subterránea de la zona del Barrio Cerro Los Leones, se caracteriza por el movimiento del agua en concordancia con el flujo regional, en sentido SO-NE. Las líneas equipotenciales correspondientes demarcaron un flujo radial convergente desde las sierras hacia el barrio, con tendencia a volverse paralelo aguas abajo.

\subsubsection{Estimación de la recarga mediante balance de cloruros}

A efectos de tener una idea de la recarga local, se ha efectuado el balance de cloruros, tal como se indicó en el apartado Metodología. Para conocer el porcentaje de 
recarga del sistema acuífero se utilizó la ecuación planteada por Custodio (1997), en donde el agua precipitada incorpora la masa de cloruros de la deposición seca.

Para ello se consideraron las concentraciones de cloruros determinadas en los muestreos de septiembre y de diciembre de 2007, presentadas más adelante en las Tablas 9 y 11. Se calculó el valor medio sin considerar muestras potencialmente afectadas por contaminación puntual, con valores elevados respecto a las restantes. Los valores medios fueron de $25.04 \mathrm{mg} \mathrm{Cl}^{-} / 1$ y $23.38 \mathrm{mg} \mathrm{Cl}^{-} / 1$ respectivamente para cada fecha.

El valor considerado de cloruros en las precipitaciones fue brindado por el Dr. Alejandro Ruiz de Galarreta, mediante comunicación personal, quien desde agosto de 2004 realiza mediciones mensuales de concentración de cloruros del agua de lluvia más deposición seca, en la localidad de Tandil. El valor medio para el período agosto 2004 julio 2007 fue de $4.66 \mathrm{ppm} \mathrm{Cl}^{-}$. El mismo resulta coincidente con el determinado por Varni (2004), para la cuenca del Arroyo Azul, que alcanza $4.6 \mathrm{ppm} \mathrm{Cl}^{-}$.

La precipitación para el período Septiembre 2007 - Agosto 2008 fue de $637 \mathrm{~mm}$ tal como se indicó en la Tabla 4.

De este modo, la recarga fue de $118.55 \mathrm{~mm}$ de acuerdo a los valores establecidos en septiembre de 2007 y de $126.96 \mathrm{~mm}$ para diciembre de 2007, lo que equivale a $18.61 \%$ y $19.93 \%$ del total precipitado, respectivamente.

Estos valores han sido concordantes en gran medida con los determinados regionalmente por Barranquero (2009) para la cuenca del Arroyo Langueyú, que oscilaron desde $17 \%$ al Sur de la cuenca, donde se ubica el Barrio Cerro Los Leones, disminuyendo hasta $7 \%$ al Norte de la misma.

\subsubsection{Hidroquímica subterránea}

Como se indicó en la metodología, se tomaron muestras en la red de perforaciones y en los 3 establecimientos barriales, haciendo un total de 18 sitios. Los mismos fueron detallados en el ítem 3.2.2, Tabla 5, y localizados en la Figura 29. Las fechas de muestreo coincidieron con las mediciones de los niveles estáticos, detalladas en el ítem 3.2.3.

Al igual que lo sucedido con el censo de niveles, en diversas ocasiones algunas muestras no pudieron ser extraídas debido a la ausencia de los habitantes en las viviendas que conformaron la red de monitoreo. 
En todos los censos se midieron $\mathrm{pH}$, conductividad eléctrica y nitratos, mientras que sólo en los dos primeros (septiembre y diciembre de 2007), se analizaron todos los iones mayoritarios presentes.

La descripción de la hidroquímica subterránea incluyó tres dimensiones. La primera se basó en los valores de conductividad eléctrica como expresión del grado de salinidad. La segunda evaluó las concentraciones de iones mayoritarios y permitió la caracterización y su clasificación. La última se enfocó especialmente a las concentraciones de nitratos, las cuales fueron consideradas especialmente en relación a la calidad del agua para consumo humano.

\section{Conductividad eléctrica y salinidad}

Con respecto a la conductividad eléctrica (CE), en la Tabla 9 se indican los valores para cada muestreo, los cuales presentaron variaciones muy leves a lo largo del año de estudio, tal como se visualiza en el análisis estadístico y en la Figura 39.

Abordando el análisis por muestra, se observó que la CE presentó valores medios entre $682 \mu \mathrm{S} / \mathrm{cm}$ en la perforación $\mathrm{N}^{\circ} 8$ hasta $1027 \mu \mathrm{S} / \mathrm{cm}$ en la $\mathrm{N}^{\circ} 2$. Ambas muestras se correspondieron respectivamente, y en la mayoría de los casos, con los tenores mínimos y máximos de cada censo.

Considerando la relación existente entre la conductividad eléctrica y el contenido de sales totales en el agua, se estimó la salinidad según Custodio y Llamas (1976), obteniéndose un valor medio de $546.6 \mathrm{mg} / \mathrm{l}$. De acuerdo a su baja salinidad y a la abundancia relativa del anión bicarbonato, se pudo especificar que son aguas jóvenes, a pesar de los incrementos de nitratos producto de la actividad antrópica.

En la primera fecha, correspondiente a Septiembre de 2007, se analizaron las variaciones de la concentración salina a partir de los valores de conductividad eléctrica, que oscilaron entre 640 y $1030 \mu \mathrm{S} / \mathrm{cm}$. El promedio para las 15 perforaciones muestreadas

fue de $791.33 \mu \mathrm{S} / \mathrm{cm}$, aunque se destacaron los sitios $\mathrm{N}^{\mathrm{o}}$ 2, 5, 6 y 14 con los mayores valores, superiores a $900 \mu \mathrm{S} / \mathrm{cm}$.

El grado de salinidad se pudo apreciar indirectamente en el mapa de isoconductividades (Figura 40). Se determinó un incremento en los valores hacia la zona central del barrio, donde la densidad de viviendas es mayor. 
Tabla 9. Conductividad eléctrica $(\mu \mathrm{S} / \mathrm{cm})$ y salinidad $(\mathrm{mg} / \mathrm{l})$ y análisis estadístico por censo.

\begin{tabular}{|c|c|c|c|c|c|c|c|}
\hline $\mathrm{N}^{\mathrm{o}}$ & $\begin{array}{c}\text { CE } \\
\text { Sep } 07\end{array}$ & $\begin{array}{c}\text { CE } \\
\text { Dic } 07\end{array}$ & $\begin{array}{c}\text { CE } \\
\text { Mar } 08\end{array}$ & $\begin{array}{c}\text { CE } \\
\text { Jun } 08\end{array}$ & $\begin{array}{c}\text { CE } \\
\text { Sep } 08\end{array}$ & $\begin{array}{c}\text { CE } \\
\text { Media }\end{array}$ & $\begin{array}{c}\text { Salinidad } \\
(\mathrm{mg} / \mathrm{l})\end{array}$ \\
\hline 1 & 751 & 813 & 820 & 762 & SD & 786,5 & 550,6 \\
\hline 2 & 1033 & 996 & 1024 & 1036 & 1050 & 1027,8 & 719,5 \\
\hline 3 & 814 & 783 & 746 & 753 & 734 & 766,0 & 536,2 \\
\hline 4 & 734 & 760 & 802 & 747 & 822 & 773,0 & 541,1 \\
\hline 5 & 912 & 893 & 886 & 841 & 846 & 875,6 & 612,9 \\
\hline 6 & 958 & 959 & 854 & 836 & 920 & 905,4 & 633,8 \\
\hline 7 & 724 & 679 & 740 & 681 & 692 & 703,2 & 492,2 \\
\hline 8 & 708 & 677 & 684 & SD & 660 & 682,3 & 477,6 \\
\hline 9 & 778 & 791 & SD & 761 & SD & 776,7 & 543,7 \\
\hline 10 & 706 & 756 & 738 & 714 & 719 & 726,6 & 508,6 \\
\hline 11 & 707 & SD & 700 & 706 & 797 & 727,5 & 509,3 \\
\hline 12 & 772 & 737 & 763 & 763 & 781 & 763,2 & 534,2 \\
\hline 13 & 643 & 684 & 748 & 771 & 774 & 724,0 & 506,8 \\
\hline 14 & 922 & SD & 961 & 943 & 965 & 947,8 & 663,4 \\
\hline 15 & 708 & 717 & 713 & SD & 721 & 714,8 & 500,3 \\
\hline 16 & SD & 724 & 719 & 652 & 683 & 694,5 & 486,2 \\
\hline 17 & SD & 701 & 710 & 695 & 702 & 702,0 & 491,4 \\
\hline 18 & SD & 790 & 742 & 744 & 765 & 760,3 & 532,2 \\
\hline Mínimo & 643 & 677 & 684 & 652 & 660 & & \\
\hline Máximo & 1033 & 996 & 1024 & 1036 & 1050 & & \\
\hline Promedio & 791.3 & 778.8 & 785.3 & 775.3 & 789.4 & & \\
\hline $\mathrm{DE}$ & 112.95 & 96.24 & 95.72 & 98.66 & 109.21 & & \\
\hline CV\% & 14.3 & 12.4 & 12.2 & 12.7 & 13.8 & & \\
\hline
\end{tabular}

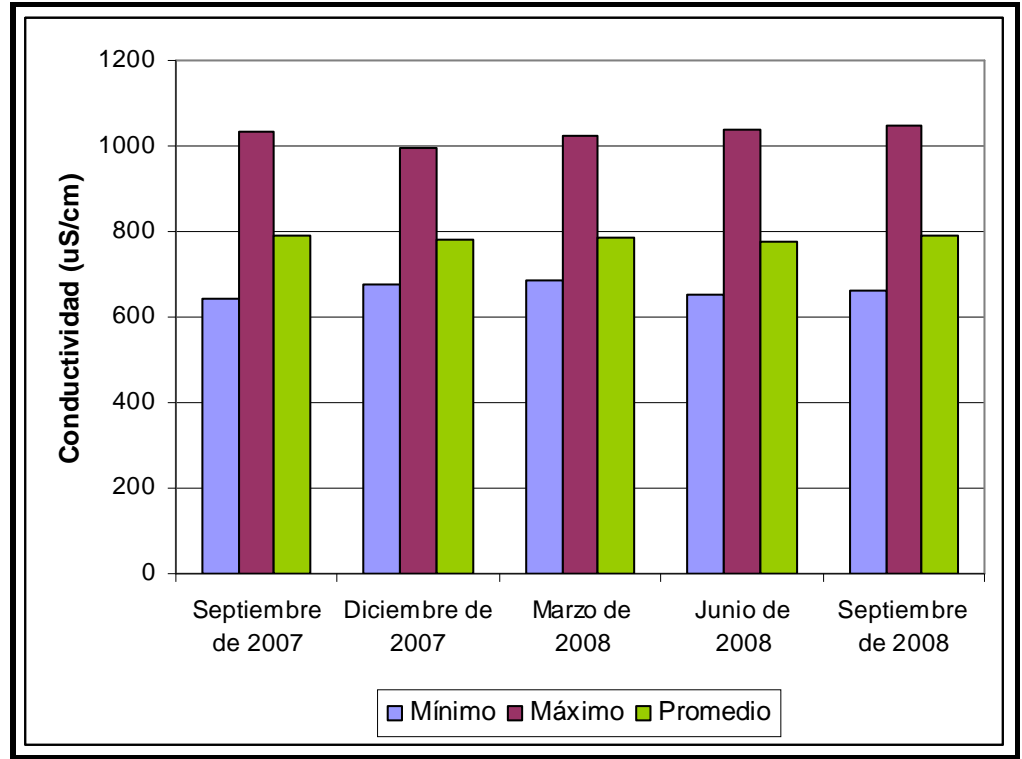

Figura 39. Valores medios, máximos y mínimos de conductividad eléctrica en el período. 
En las posteriores mediciones, tanto los valores individuales como el promedio para las muestras se mantuvieron a lo largo del año de estudio (Tabla 9). Los mapas de isoconductividades para los demás censos resultaron muy similares al presentado en la Figura 40, confirmando el incremento de la conductividad eléctrica y por ende la salinidad total hacia la zona de mayor densidad de viviendas.

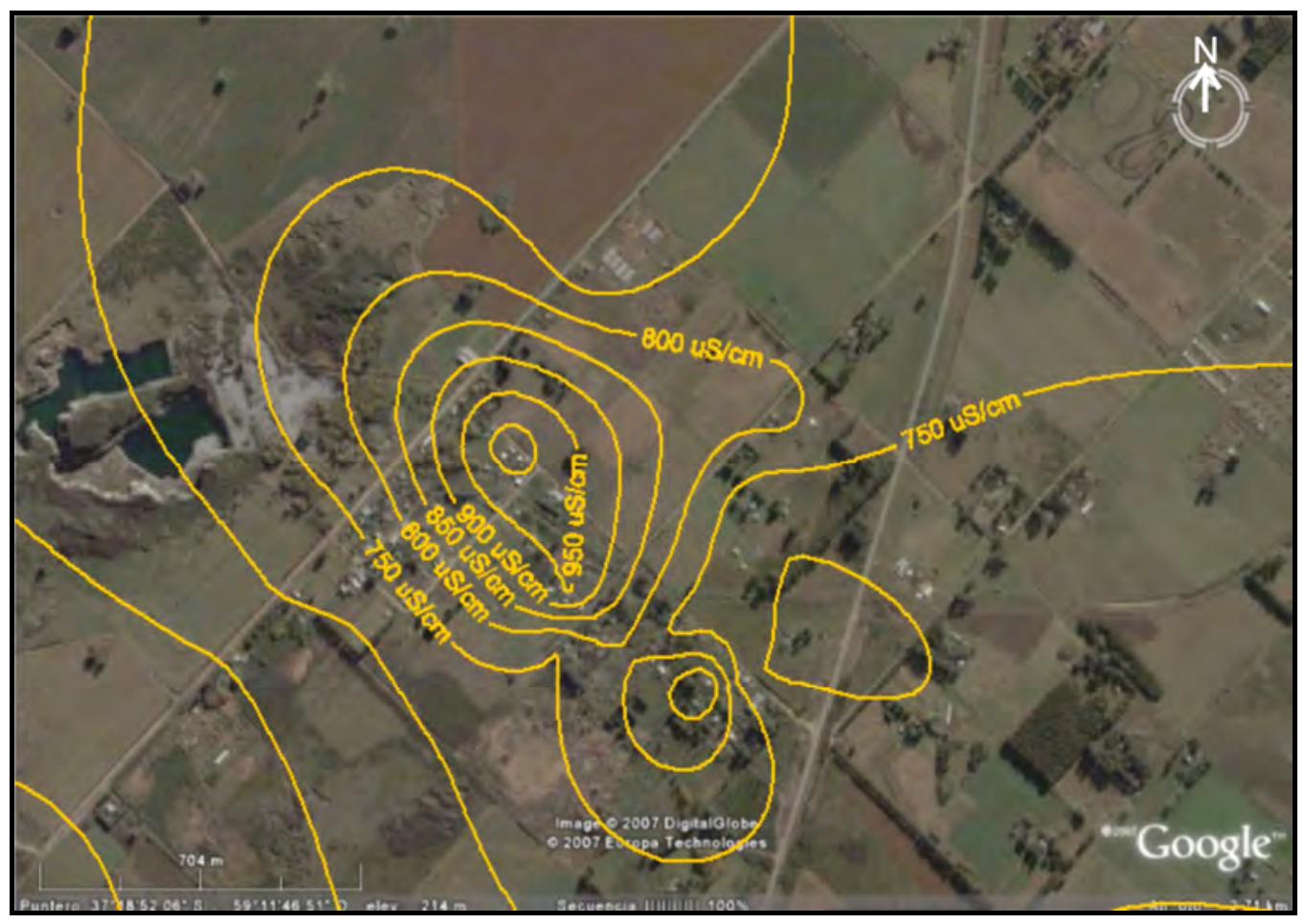

Figura 40. Mapa de isoconductividades para septiembre de 2007.

\section{Iones mayoritarios y $\mathbf{p H}$}

En primer lugar, la Tabla 10 presenta los resultados de $\mathrm{pH}$ y concentraciones de los cationes y aniones mayoritarios, correspondientes a las muestras de septiembre de 2007.

Los valores medios indicaron que el anión predominante es el bicarbonato, con 488 $\mathrm{mg} / \mathrm{l}$, seguido por el cloruro y en menor medida el sulfato. En cuanto a los cationes, abundó el Calcio con un promedio de $72.77 \mathrm{mg} / \mathrm{l}$, y en menor medida se presentaron el Sodio, el Magnesio y por último el Potasio.

El coeficiente de variación calculado reflejó la representatividad de los valores medios respecto al conjunto de datos. Solamente los cloruros y sulfatos presentaron menos homogeneidad, con coeficientes de variación de $43 \%$. 
Tabla 10. Resultados físico-químicos (septiembre de 2007) y análisis estadístico.

\begin{tabular}{|c|c|c|c|c|c|c|c|c|c|}
\hline $\begin{array}{c}\text { Sitio de } \\
\text { muestreo }\end{array}$ & $\frac{\pi}{2}$ & 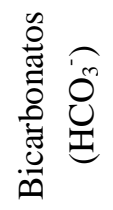 & 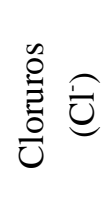 & 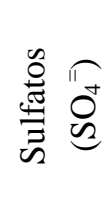 & $\frac{0}{\frac{0}{\pi}} \stackrel{\widetilde{\pi}}{\tilde{U}}$ & 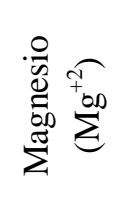 & 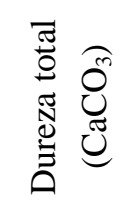 & $\begin{array}{l}\stackrel{0}{0} \\
\stackrel{\Xi}{0} \\
\stackrel{0}{0}\end{array}$ & 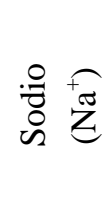 \\
\hline & & $\mathrm{mg} / \mathrm{l}$ & $\mathrm{mg} / \mathrm{l}$ & $\mathrm{mg} / \mathrm{l}$ & $\mathrm{mg} / \mathrm{l}$ & $\mathrm{mg} / \mathrm{l}$ & $\mathrm{mg} / \mathrm{l}$ & $\mathrm{mg} / \mathrm{l}$ & $\mathrm{mg} / \mathrm{l}$ \\
\hline 1 & 7,8 & 463,6 & 37,49 & 20,67 & 92,37 & 21,47 & 319,07 & 1,21 & 41,59 \\
\hline 2 & 8 & 500,2 & 65,48 & 29,33 & 88,84 & 49,97 & 427,62 & 0,86 & 49,85 \\
\hline 3 & 7,7 & 518,5 & 32,99 & 20,27 & 77,78 & 32,43 & 327,75 & 9,22 & 44,72 \\
\hline 4 & 7,6 & 494,1 & 26,49 & 12,00 & 63,72 & 35,69 & 306,09 & 4,72 & 47,09 \\
\hline 5 & 7,9 & 542,9 & 31,49 & 19,47 & 87,50 & 46,13 & 408,45 & 3,30 & 45,66 \\
\hline 6 & 8 & 536,8 & 52,48 & 37,60 & 80,42 & 44,52 & 384,15 & 1,87 & 52,40 \\
\hline 7 & 7,7 & 494,1 & 16,99 & 10,93 & 60,16 & 39,16 & 311,49 & 4,14 & 43,68 \\
\hline 8 & 7,9 & 445,3 & 20,99 & 11,73 & 77,91 & 34,84 & 338,02 & 3,20 & 41,31 \\
\hline 9 & 7,7 & 506,3 & 23,99 & 14,93 & 63,31 & 41,65 & 329,61 & 5,56 & 55,49 \\
\hline 10 & 7,8 & 518,5 & 30,49 & 17,07 & 78,33 & 37,50 & 350,02 & 3,79 & 45,01 \\
\hline 11 & 7,7 & 457,5 & 18,49 & 11,73 & 43,54 & 30,76 & 235,38 & 3,18 & 43,84 \\
\hline 12 & 7,9 & 481,9 & 31,99 & 17,33 & 79,83 & 20,67 & 284,45 & 3,15 & 36,92 \\
\hline 13 & 8 & 408,7 & 19,99 & 14,40 & 63,09 & 25,42 & 262,19 & 3,23 & 28,42 \\
\hline 14 & 7,6 & 469,7 & 45,49 & 34,67 & 88,59 & 37,64 & 376,21 & 7,11 & 47,61 \\
\hline 15 & 7,7 & 481,9 & 21,49 & 15,47 & 46,15 & 43,80 & 295,58 & 3,60 & 45,93 \\
\hline Mínimo & 7.6 & 408.7 & 16.99 & 10.93 & 43.54 & 20.67 & 235.38 & 0.86 & 28.42 \\
\hline Máximo & 8 & 542.9 & 65.48 & 37.60 & 92.37 & 49.97 & 427.62 & 9.22 & 55.49 \\
\hline Promedio & 7.8 & 488 & 31.76 & 19.17 & 72.77 & 36.11 & 330.41 & 3.87 & 44.64 \\
\hline $\mathrm{DE}$ & 0.14 & 35.72 & 13.71 & 8.36 & 15.33 & 8.77 & 52.82 & 2.16 & 6.37 \\
\hline $\mathrm{CV} \%$ & 1.81 & 7.32 & 43.18 & 43.61 & 21.06 & 24.30 & 15.99 & 55.73 & 14.26 \\
\hline
\end{tabular}

Con los datos de la Tabla 10, y a efectos de tipificar el agua subterránea y permitir su comparación, se construyó la representación gráfica logarítmica utilizando el Diagrama de Schoeller tomando los datos de cinco muestras (Figura 41). Este diagrama es útil para resaltar la composición iónica del agua y establecer relaciones entre los iones presentes en una muestra y entre diferentes muestras (Custodio y Llamas, 1976).

En cuanto a los aniones, se observó claramente la gran concentración del bicarbonato en relación a los sulfatos y cloruros. Con respecto a los cationes, existió una mayor concentración del Calcio, seguida por la de Magnesio, y en menor medida Sodio y Potasio.

Del mismo modo, el Diagrama de Piper representa los aniones y cationes principales y es útil para agrupar aguas geoquímicamente similares (Custodio y Llamas, 1976). A partir de los datos de la Tabla 10 se realizó dicho diagrama para 10 de las 
muestras analizadas (Figura 42). El mismo determinó la predominancia del anión bicarbonato y el catión Calcio acompañado por el Magnesio, sobre el resto de los compuestos mayoritarios.

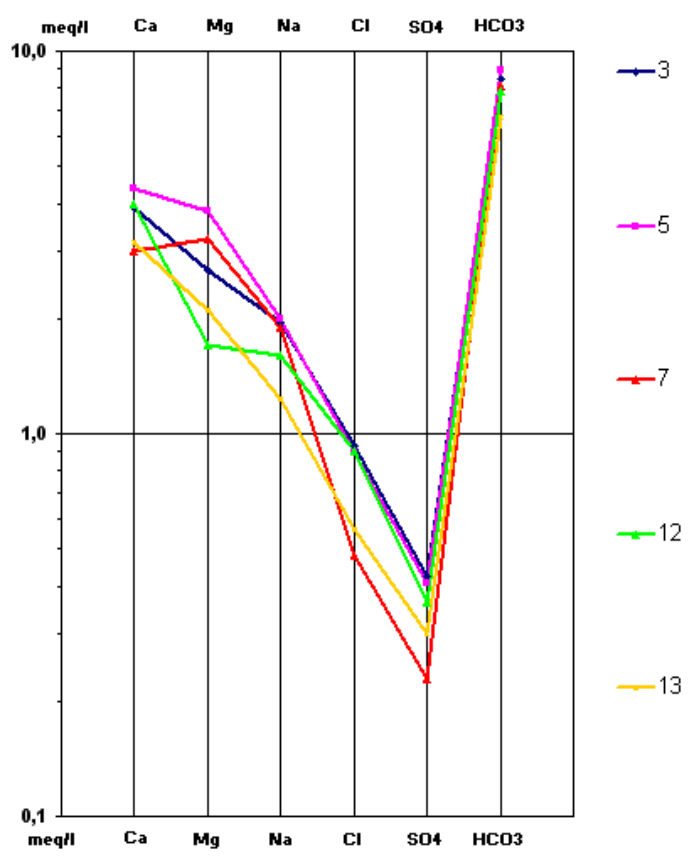

Figura 41. Diagrama de Schoeller para cinco muestras.

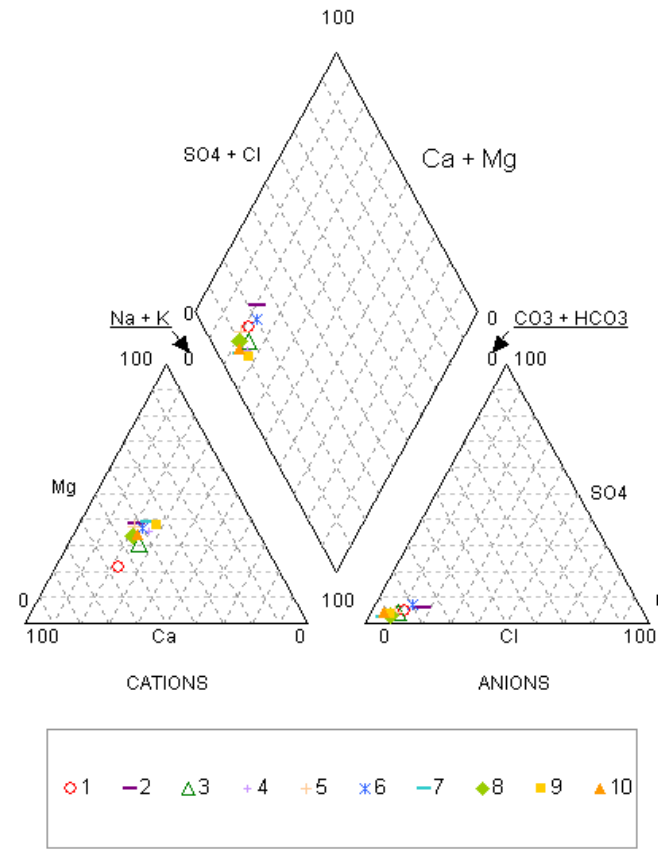

Figura 42. Diagrama de Piper para diez muestras.

A partir ambos análisis se pudieron clasificar las aguas como bicarbonatadas cálcicas-magnésicas.

En general, las concentraciones en la mayoría de los iones analizados, fueron inferiores a los valores límites aconsejados y establecidos para el agua potable según el Código Alimentario Argentino (1969, actualizado en 2007) que se presentan en la Tabla 11 , donde $\mathrm{SR}$ es sin valor recomendado.

Tabla 11. Parámetros químicos recomendados para agua potable por el CAA.

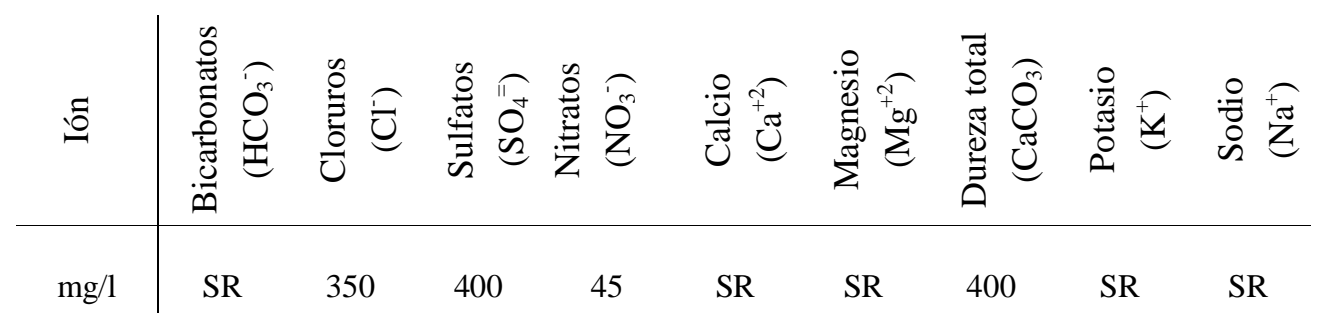

En Diciembre 2007, en la segunda oportunidad, se realizaron nuevamente los análisis físico-químicos sobre 16 muestras (Tabla 12). En general no se observaron 
variaciones importantes en los parámetros evaluados, confirmándose de este modo las características y la clasificación de las aguas antes descriptas.

Tabla 12. Resultados físico-químicos (diciembre de 2007) y análisis estadístico.

\begin{tabular}{|c|c|c|c|c|c|c|c|c|c|}
\hline $\begin{array}{c}\text { Sitio de } \\
\text { muestreo }\end{array}$ & $\frac{T}{2}$ & 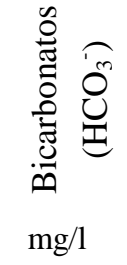 & $\begin{array}{l}\underset{\tilde{\Xi}}{\tilde{\Xi}} \widetilde{\Xi} \\
\mathrm{mg} / \mathrm{l}\end{array}$ & 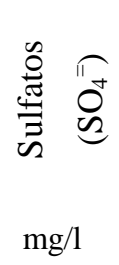 & 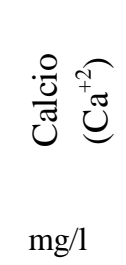 & 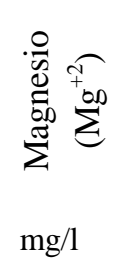 & 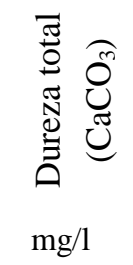 & 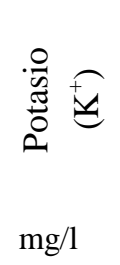 & 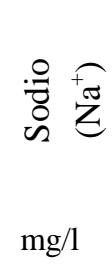 \\
\hline 1 & 8,2 & 445,3 & 39,99 & 16,76 & 96,75 & 23,57 & 338,65 & 2,88 & 31,61 \\
\hline 2 & 8,2 & 494,1 & 58,98 & 27,25 & 89,24 & 51,08 & 433,19 & 2,80 & 39,21 \\
\hline 3 & 7,9 & 494,1 & 26,99 & 13,30 & 67,03 & 36,98 & 319,67 & 6,30 & 31,15 \\
\hline 4 & 8,2 & 494,1 & 24,49 & 7,21 & 68,28 & 35,04 & 314,78 & 6,72 & 43,38 \\
\hline 5 & 8,4 & 512,4 & 25,49 & 15,26 & 90,73 & 42,54 & 401,71 & 4,01 & 34,20 \\
\hline 6 & 8,4 & 518,5 & 52,98 & 35,11 & 95,99 & 45,50 & 427,07 & 4,71 & 37,90 \\
\hline 7 & 7,9 & 451,4 & 18,99 & 6,55 & 58,18 & 37,63 & 300,23 & 3,62 & 31,23 \\
\hline 8 & 8 & 420,9 & 17,99 & 9,46 & 84,71 & 36,90 & 363,47 & 3,63 & 25,12 \\
\hline 9 & 8,4 & 469,7 & 24,99 & 11,70 & 66,26 & 38,35 & 323,38 & 6,09 & 31,82 \\
\hline 10 & 7,9 & 469,7 & 25,99 & 14,14 & 73,03 & 35,66 & 329,21 & 6,10 & 27,42 \\
\hline 12 & 8,2 & 433,1 & 27,99 & 12,17 & 105,86 & 22,70 & 357,79 & 4,73 & 19,60 \\
\hline 13 & 8,1 & 372,1 & 20,99 & 10,67 & 76,33 & 27,14 & 302,36 & 2,66 & 17,18 \\
\hline 15 & 8,1 & 451,4 & 18,99 & 9,18 & 55,08 & 43,08 & 314,96 & 3,82 & 27,82 \\
\hline 16 & 7,9 & 427 & 22,49 & 12,73 & 74,16 & 33,22 & 355,18 & 3,77 & 24,66 \\
\hline 17 & 8,1 & 427 & 20,49 & 7,02 & 70,76 & 32,40 & 374,91 & 3,53 & 30,89 \\
\hline 18 & 8 & 414,8 & 27,99 & 17,88 & 109,83 & 23,78 & 443,49 & 6,39 & 25,83 \\
\hline Mínimo & 7.90 & 372.10 & 17.99 & 6.55 & 55.08 & 22.70 & 300.23 & 2.66 & 17.18 \\
\hline Máximo & 8.4 & 518.50 & 58.98 & 35.11 & 109.83 & 51.08 & 443.49 & 6.72 & 43.38 \\
\hline Promedio & 8.12 & 455.98 & 28.49 & 14.15 & 80.14 & 35.35 & 356.25 & 4.49 & 29.94 \\
\hline $\mathrm{DE}$ & 0.18 & 40.12 & 11.99 & 7.58 & 16.51 & 8.14 & 47.57 & 1.40 & 6.87 \\
\hline $\mathrm{CV} \%$ & 2.21 & 8.80 & 42.07 & 53.54 & 20.60 & 23.04 & 13.35 & 31.28 & 22.93 \\
\hline
\end{tabular}

\section{Concentraciones de nitratos}

Otra de las características químicas analizadas en detalle, correspondió a las concentraciones de nitratos en la zona de estudio. La Tabla 13 presenta los resultados así como el análisis estadístico realizado.

El análisis por muestra indicó valores medios que oscilan desde $9.91 \mathrm{mg} / \mathrm{l}$ en la perforación $\mathrm{N}^{\mathrm{o}} 4$ hasta $108.83 \mathrm{mg} / \mathrm{l}$ en la $\mathrm{N}^{\mathrm{o}} 2$. 
Tabla 13. Concentraciones de nitratos (mg/l) y análisis estadístico.

\begin{tabular}{c|cccccc}
$\mathrm{N}^{\mathbf{c}}$ & Sep 07 & Dic 07 & Mar 08 & Jun 08 & Sep 08 & Promedio \\
\cline { 2 - 7 } 1 & 40,13 & 41,22 & 54,96 & 42,32 & $\mathrm{SD}$ & 44,66 \\
2 & 118,38 & 98,63 & 116,38 & 108,66 & 102,10 & 108,83 \\
3 & 28,15 & 17,57 & 28,04 & 21,98 & 17,21 & 22,59 \\
4 & 17,84 & 4,71 & 8,02 & 13,13 & 5,84 & 9,91 \\
5 & 104,60 & 77,71 & 80,52 & 70,92 & 53,96 & 77,54 \\
6 & 54,62 & 62,30 & 43,79 & 48,51 & 65,43 & 54,93 \\
7 & 27,39 & 21,77 & 21,28 & 23,49 & 13,79 & 21,55 \\
8 & 36,45 & 27,37 & 28,82 & $\mathrm{SD}$ & 26,12 & 29,69 \\
9 & 31,08 & 27,15 & $\mathrm{SD}$ & 30,11 & $\mathrm{SD}$ & 29,45 \\
10 & 23,88 & 18,82 & 18,89 & 15,82 & 13,90 & 18,26 \\
11 & 41,38 & $\mathrm{SD}$ & 38,81 & 46,34 & 69,13 & 48,92 \\
12 & 46,07 & 40,71 & 44,52 & 43,74 & 39,03 & 42,81 \\
13 & 48,28 & 49,23 & 36,86 & 43,80 & 35,88 & 42,81 \\
14 & 108,31 & $\mathrm{SD}$ & 104,80 & 111,23 & 100,99 & 106,33 \\
15 & 32,80 & 27,84 & 28,48 & $\mathrm{SD}$ & 22,57 & 27,92 \\
16 & $\mathrm{SD}$ & 34,53 & 37,61 & 33,63 & 30,67 & 34,11 \\
17 & $\mathrm{SD}$ & 27,47 & 36,24 & 31,14 & 30,61 & 31,36 \\
18 & $\mathrm{SD}$ & 34,30 & 58,48 & 30,10 & 32,50 & 38,84 \\
Mínimo & 17.84 & 4.71 & 8.02 & 13.13 & 5.84 & \\
Máximo & 118.38 & 98.63 & 116.38 & 111.23 & 102.10 & \\
Promedio & 50.62 & 38.21 & 46.26 & 44.68 & 41.23 & \\
DE & 32.52 & 23.96 & 29.43 & 29.16 & 29.49 & \\
$\mathrm{CV} \%$ & 64.24 & 62.72 & 63.61 & 65.27 & 71.52 & \\
& & & & & &
\end{tabular}

El análisis a lo largo del año de estudio demostró leves variaciones (Figura 43). Los valores mínimos oscilaron entre $4.71 \mathrm{mg} / 1$ y $17.84 \mathrm{mg} / \mathrm{l}$, mientras que los máximos variaron entre $98.63 \mathrm{mg} / \mathrm{l}$ y $118.38 \mathrm{mg} / \mathrm{l}$. El promedio mostró un leve descenso desde $50.62 \mathrm{mg} / \mathrm{l}$ en septiembre de 2007 hasta alcanzar 41.23 en septiembre de 2008.

En todos los censos el coeficiente de variación fue elevado, superando el $60 \%$ debido a la heterogeneidad de los resultados y la gran amplitud entre valores mínimos y máximos. 


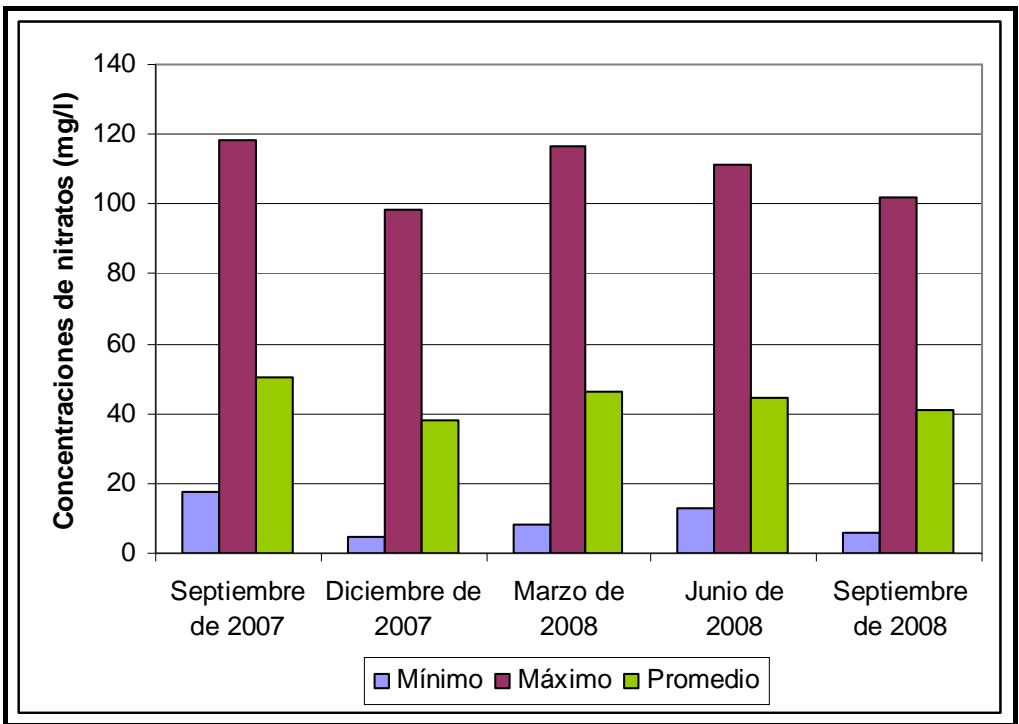

Figura 43. Valores medios, máximos y mínimos de nitratos en el período.

En el primer censo, de septiembre de 2007, las concentraciones de nitratos alcanzaron un tenor medio de $50.62 \mathrm{mg} / \mathrm{l}$. Se observa en la Tabla 13 que los sitios $\mathrm{N}^{\mathrm{o}} 2,5$ y 14 superan ampliamente ese valor, con más de $100 \mathrm{mg} / \mathrm{l}$.

La Figura 44 presenta el mapa de isoconcentraciones de nitratos para esa fecha, donde se determinó el incremento de las concentraciones en la zona de mayor densidad de viviendas. Se notó una similitud entre dicho mapa respecto a las curvas de isoconductividad eléctrica (Figura 40).

Al comparar los resultados con el límite aceptable para consumo humano de 45 $\mathrm{mg} / \mathrm{l}$, establecido por el CAA, en la Tabla 11 , se observa que en el $40 \%$ de los casos se superó dicho valor y en el $20 \%$, las concentraciones duplicaron el límite establecido como aceptable. 


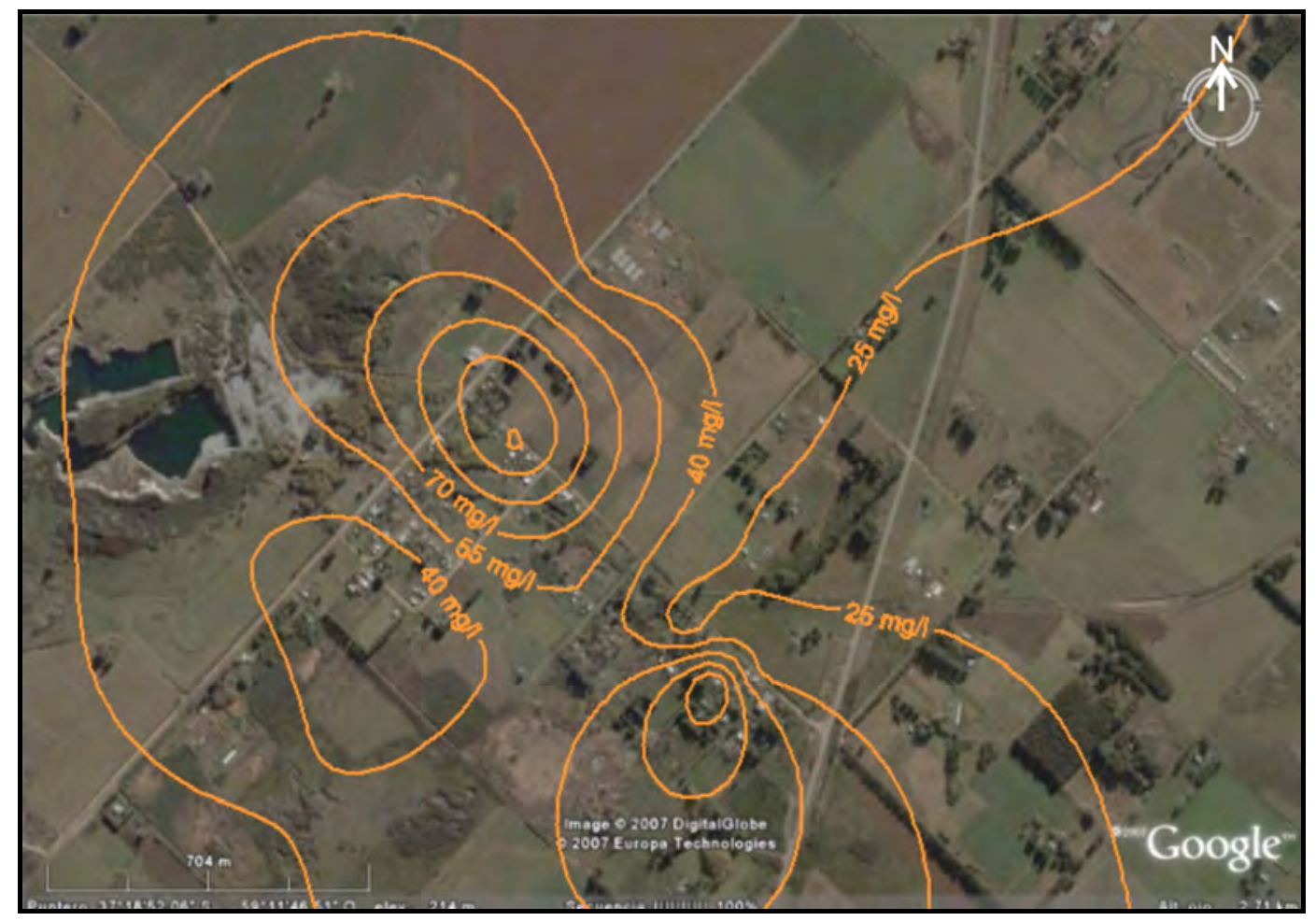

Figura 44. Mapa de isoconcentraciones de nitratos para septiembre de 2007.

En diciembre, se obtuvo un promedio de nitratos de $38.21 \mathrm{mg} / \mathrm{l}$, por debajo del valor medio registrado en el muestreo anterior. Las mayores concentraciones de dicho ión se presentaron en las perforaciones $\mathrm{N}^{\mathrm{o}} 2$ y 5 . El $25 \%$ de las muestras superaron el valor recomendado por el CAA.

En marzo de 2008, el promedio de nitratos en las muestras alcanzó $46.26 \mathrm{mg} / \mathrm{l}$, con un $30 \%$ de las muestras por encima del límite de potabilidad establecido por la legislación.

En los últimos dos muestreos, de junio y septiembre de 2008, las concentraciones medias de nitratos fueron de $44.68 \mathrm{mg} / \mathrm{l}$ y de $41.23 \mathrm{mg} / \mathrm{l}$ respectivamente, presentándose en ambos casos el $31 \%$ de muestras por encima de $45 \mathrm{mg} / \mathrm{l}$.

Los mapas de isoconcentraciones de nitratos para cada censo resultaron muy similares al presentado en la Figura 44, motivo por el cual no se brindan los mismos. En todos ellos se observó un importante incremento en la zona de mayor densidad poblacional. Además se apreció una clara coincidencia entre los mayores valores de la conductividad eléctrica y las concentraciones elevadas de nitratos en dicha zona, como ya se mencionara. 
A lo largo de los muestreos y análisis realizados en el año, y como se indicó anteriormente, se observaron variaciones leves de las concentraciones de nitratos. Se destacó una tendencia de descenso en la mayoría de las perforaciones estudiadas.

A modo de conclusión de este apartado, el análisis de la cartografía permitió apreciar la relación directa existente entre el incremento de la conductividad eléctrica y la mayor presencia de nitratos, que se puede explicar teniendo en cuenta el sentido de escurrimiento subterráneo local. A medida que el agua subterránea fluye hacia el NE y atraviesa la zona más poblada, las cargas contaminantes vertidas en la zona alta del barrio, son trasmitidas a través del flujo hacia la zona central del mismo, incrementando la concentración del ión nitrato y por ende la salinidad del agua.

\subsubsection{Calidad microbiológica}

Durante los meses de octubre y noviembre de 2007 se tomaron 18 muestras de agua en la red de perforaciones. Como se detalló en el capítulo de Metodología, se analizaron bacteriológicamente según los parámetros establecidos en el Código Alimentario Argentino (1969, actualizado en 2007). El mismo determina cuatro niveles permisibles para evaluar la aptitud del agua para consumo humano que se detallan en la Tabla 14.

Por un lado, las bacterias aeróbicas mesófilas, que incluyen patógenos y no patógenos, cuya presencia en altos niveles en agua, indica su ineptitud. Por otro lado, el grupo coliforme, que incluye bacterias de los géneros Escherichia, Citrobacter, Enterobacter y Klebsiella (Gamazo et al., 2005). Un organismo indicador de la contaminación fecal es la bacteria entérica Escherichia coli, que naturalmente habita en el intestino humano y animal, a la que se atribuyen efectos beneficiosos para la salud. Sin embargo puede provocar patologías intestinales graves. Por su último, el patógeno Pseudomona aeruginosa puede alojarse en tanques y cañerías, y puede producir alteraciones en las barreras mucocutáneas del ser humano.

Tabla 14. Parámetros microbiológicos recomendados para agua potable por el CAA.

\begin{tabular}{cccc}
$\begin{array}{c}\text { Bacterias } \\
\text { mesófilas } \\
(\mathrm{UFC} / \mathrm{ml})\end{array}$ & $\begin{array}{c}\text { Coliformes } \\
\text { totales } / 100 \mathrm{ml}\end{array}$ & $\begin{array}{c}\text { Escherichia coli } \\
\text { en } 100 \mathrm{ml}\end{array}$ & $\begin{array}{c}\text { Pseudomona } \\
\text { aeruginosa } \\
\text { en } 100 \mathrm{ml}\end{array}$ \\
\hline 500 & 3 & Ausencia & Ausencia
\end{tabular}

A partir de los análisis, en la Tabla 15 se indican los resultados para los cuatro parámetros y se detalla la aptitud para el consumo humano. Se observó que sólo cuatro muestras $(22 \%)$ resultaron aptas. 
Tabla 15. Resultados de los análisis bacteriológicos.

\begin{tabular}{|c|c|c|c|c|c|}
\hline $\begin{array}{c}\text { Muestra } \\
\mathrm{N}^{\circ}\end{array}$ & $\begin{array}{l}\text { Bacterias } \\
\text { mesófilas } \\
(\mathrm{UFC} / \mathrm{ml})\end{array}$ & $\begin{array}{c}\text { Coliformes } \\
\text { totales } / 100 \\
\mathrm{ml}\end{array}$ & $\begin{array}{l}\text { Escherichia } \\
\text { coli } \\
\text { en } 100 \mathrm{ml}\end{array}$ & $\begin{array}{c}\text { Pseudomona } \\
\text { aeruginosa } \\
\text { en } 100 \mathrm{ml}\end{array}$ & $\begin{array}{c}\text { Aptitud para } \\
\text { el consumo } \\
\text { humano }\end{array}$ \\
\hline 1 & $<10$ & 43 & Ausencia & Ausencia & No apta \\
\hline 2 & 100 & 93 & Ausencia & Ausencia & No apta \\
\hline 3 & $<10$ & 23 & Ausencia & Ausencia & No apta \\
\hline 4 & $<10$ & 0 & Ausencia & Ausencia & Apta \\
\hline 5 & 1700 & 150 & Presencia & Ausencia & No apta \\
\hline 6 & $<10$ & 0 & Ausencia & Ausencia & Apta \\
\hline 7 & 10 & 43 & Ausencia & Ausencia & No apta \\
\hline 8 & 10 & 0 & Ausencia & Ausencia & Apta \\
\hline 9 & 275 & 43 & Ausencia & Ausencia & No apta \\
\hline 10 & 275 & 1100 & Ausencia & Ausencia & No apta \\
\hline 11 & 55 & 240 & Ausencia & Ausencia & No apta \\
\hline 12 & 65 & 43 & Ausencia & Ausencia & No apta \\
\hline 13 & 205 & 75 & Ausencia & Ausencia & No apta \\
\hline 14 & 90 & 150 & Ausencia & Ausencia & No apta \\
\hline 15 & 3055 & 460 & Ausencia & Presencia & No apta \\
\hline 16 & 300 & 43 & Ausencia & Presencia & No apta \\
\hline 17 & 120 & 0 & Ausencia & Ausencia & Apta \\
\hline 18 & 360 & 240 & Presencia & Ausencia & No apta \\
\hline
\end{tabular}

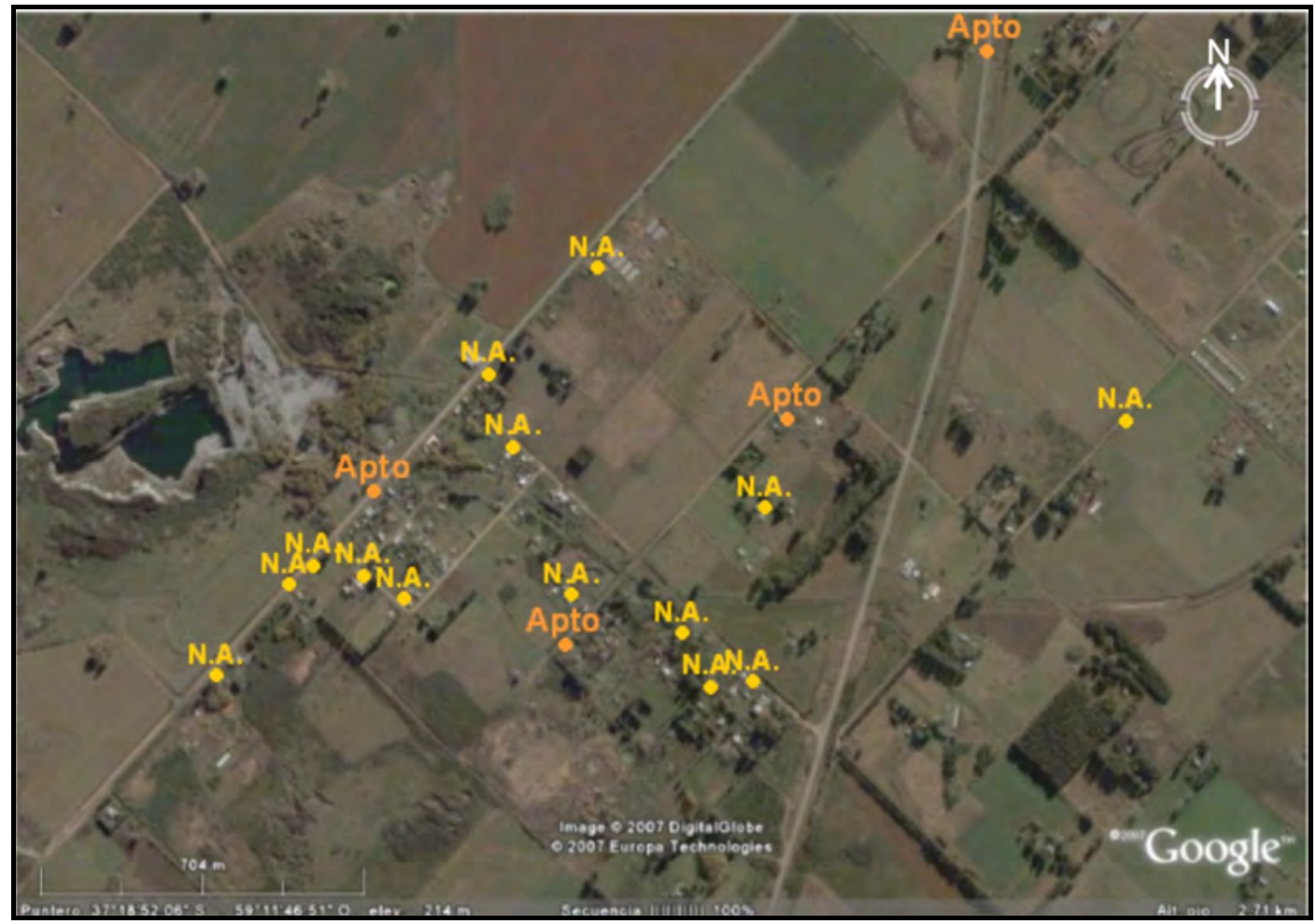

Figura 45. Distribución de los resultados bacteriológicos. 
En la Figura 45 se indica la distribución de los resultados, tanto los que se adecuaron a los parámetros establecidos (Apto) como aquellos que fueron no aptos (N.A.). Puede apreciarse que la distribución no obedece al mismo patrón descripto en la hidroquímica, observándose un carácter multipuntual de contaminación microbiológica con focos dispersos en la zona más poblada y en los alrededores.

Con respecto a bacterias mesófilas, dos muestras superaron ampliamente el valor permisible, alcanzando el $11 \%$ del total. El crecimiento se observa en la Figura 46.

El 78\% de las muestras presentaron más de 3 bacterias coliformes cada $100 \mathrm{ml}$. Los casos más graves fueron las perforaciones $\mathrm{N}^{\circ} 10$ y 15, cuyas aguas tuvieron 1100 y 460 coliformes/100 ml respectivamente. Los pozos $\mathrm{N}^{\circ} 5,11,14$ y 18 también superaron ampliamente el valor recomendado, presentando un NMP superior a 100 coliformes/100 ml. La Figura 47 ilustra una muestra con elevado número de coliformes totales.

Escherichia coli, coliforme de origen fecal, se presentó en dos casos, alcanzando el $11 \%$ del total. Su posible presencia fue evidenciada en tubos con cambio de coloración y generación de gas, y confirmada mediante la siembra en EMB (Figura 48). Cabe destacar la gravedad que representa en agua de bebida, como se explicó anteriormente.

Finalmente, se realizó el aislamiento e identificación de Pseudomona aeruginosa, partiendo de tubos con evidencias de velo (Figura 49) y luego confirmándose en placa (Figura 50). Esta bacteria fue detectada en dos de las muestras (11\%) pertenecientes a pozos del Barrio Cerro Los Leones.

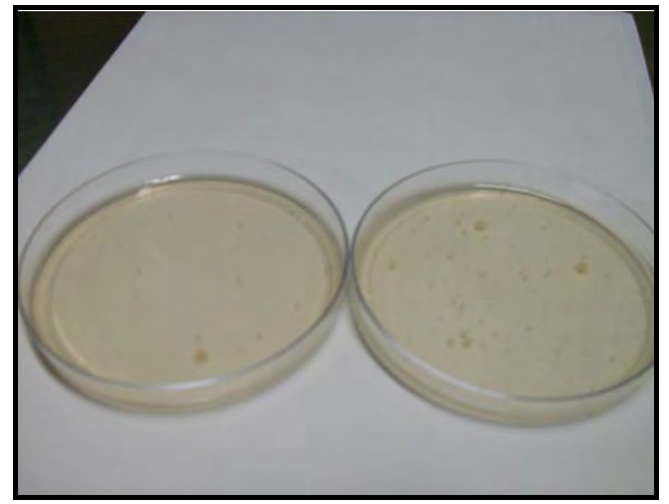

Figura 46. Recuento de mesófilos. 


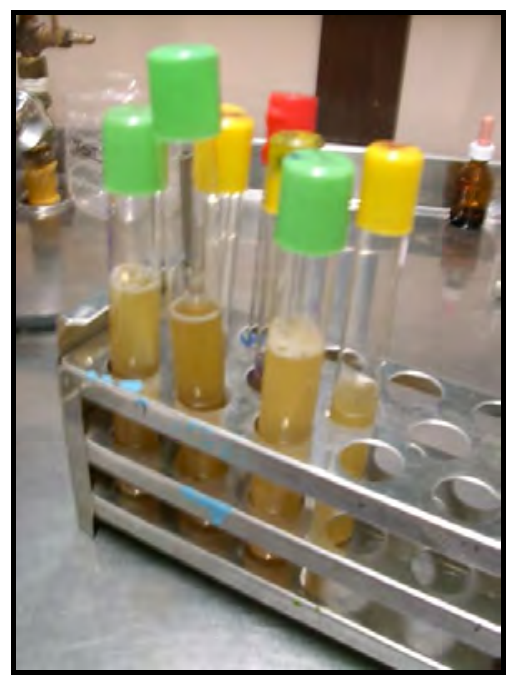

Figura 47. Muestra con

altos niveles de coliformes totales.

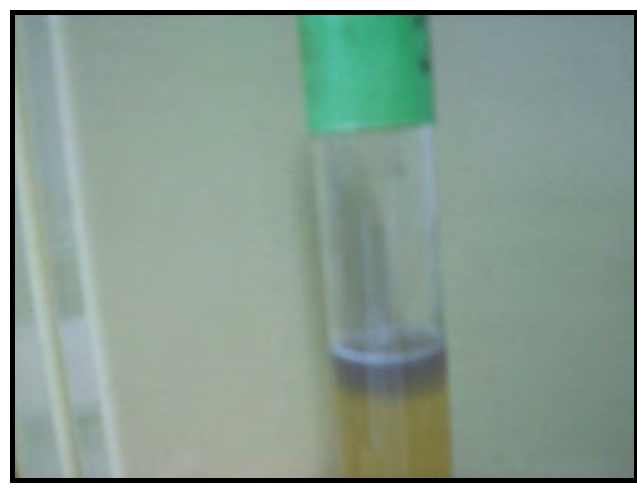

Figura 49. Formación de velo superficial en tubos para análisis de $\mathrm{P}$. aeruginosa

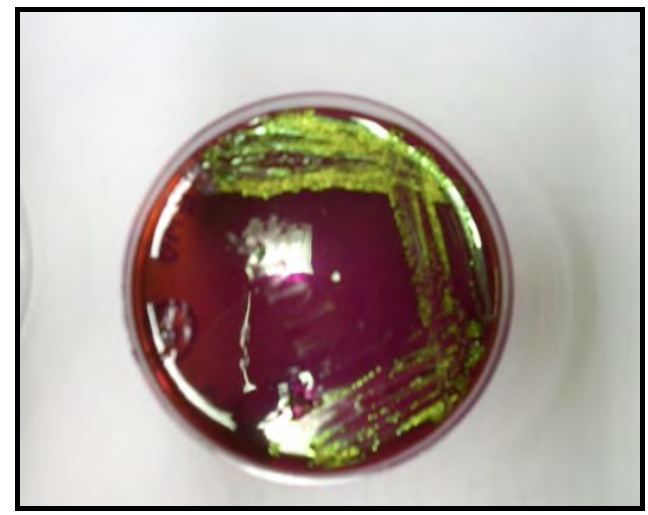

Figura 48. Confirmación de E. coli

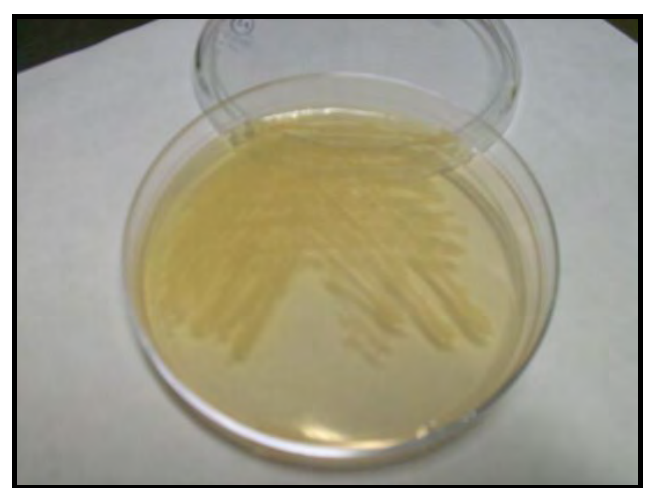

Figura 50. Determinación de P. aeruginosa.

Analizando los resultados y a modo de conclusión de este apartado, se observó que solamente cuatro de las muestras analizadas, lo que equivale al $22 \%$, ha resultado ser apta para el consumo humano en función de los límites permisibles establecidos en el Código Alimentario Argentino. El 78\% restante ha superado uno o más de dichos valores, determinando que la población que consume este agua subterránea se encuentra en riesgo elevado respecto a las enfermedades hídricas relacionadas con estos agentes microbiológicos. 


\section{SUBSISTEMA SOCIAL}

\subsection{Abastecimiento de agua potable y cloacas en la ciudad de Tandil}

A partir de los antecedentes e información obtenida sobre el uso del recurso hídrico subterráneo en la ciudad de Tandil, se describió la gestión actual, haciendo hincapié en la cobertura de servicios de agua y cloacas brindada por el Municipio, por medio del ente Obras Sanitarias Tandil.

Ambas redes no abastecen la totalidad de la ciudad. La cobertura de agua tiene mayor extensión que el servicio cloacal como se indica en las Figuras 51 y 52, y aún así quedan desprovistos diferentes barrios periféricos. Estos incluyen sectores de bajos ingresos y con problemáticas que afectan su calidad de vida, así como otros constituidos por familias de alto nivel de vida y sin deficiencias en sus necesidades básicas. El Plan de Ordenamiento Territorial del Municipio de Tandil (AYDET y FCH - UNCPBA, 2004) da a conocer que la cobertura cloacal alcanzaba por entonces el $62 \%$ de la ciudad.

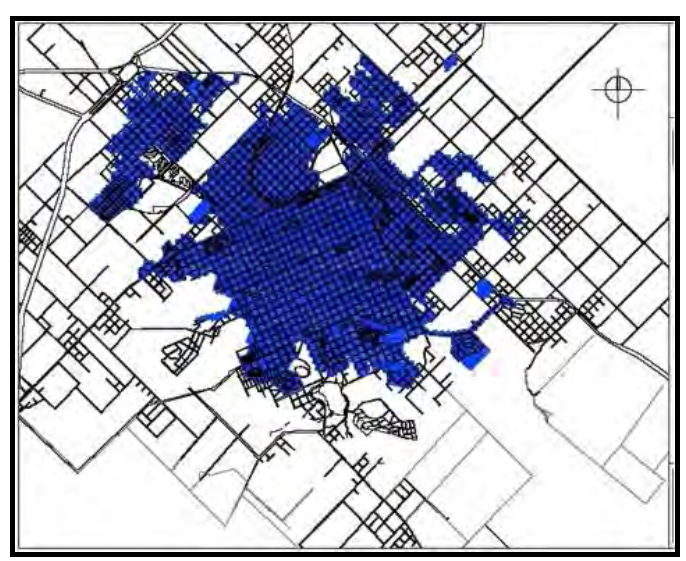

Figura 51. Cobertura de la red de agua potable (AYDET y FCH-UNCPBA, 2004).

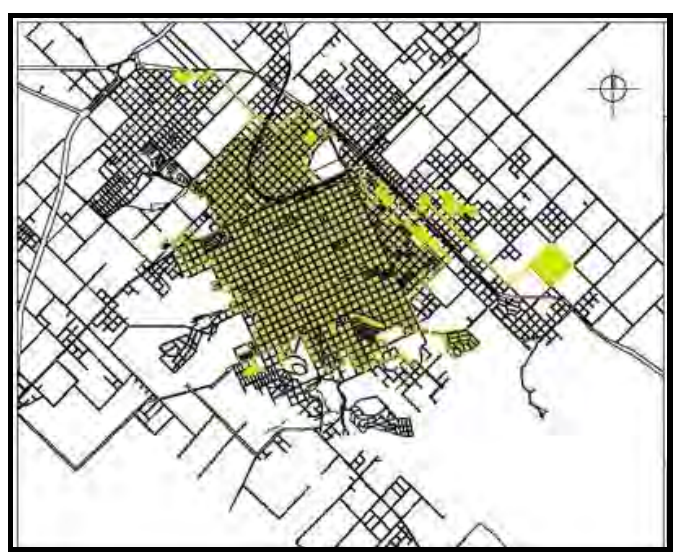

Figura 52. Cobertura de la red cloacal (AYDET y FCH-UNCPBA, 2004).

Según el Secretario de Planeamiento y Obras Públicas del Municipio de Tandil, a través de la información publicada en medios locales (Diario El Eco de Tandil, 09/02/2009), el abastecimiento de agua potable alcanzaba, a la fecha, el $96 \%$ de la población urbana mientras que el $79 \%$ se encontraba cubierto por red cloacal. Sin embargo, se vuelve interesante conocer sobre qué área se han determinado estos valores, debido a que en la actualidad se identifican numerosos sectores de la periferia urbana sin ambos servicios.

Actualmente es necesario considerar el crecimiento que ha experimentado la ciudad, sobre todo la ampliación del ejido urbano hacia el Norte, Noreste y el sector Sur, donde no se cuenta con los servicios mencionados. Además, la población se ha 
concentrado debido a la construcción de edificios de altura en la zona céntrica y de numerosos complejos habitacionales en diferentes sectores del área urbana.

Para el conocimiento de la gestión actual de los recursos hídricos en la ciudad y las problemáticas existentes, se identificaron y entrevistaron los siguientes informantes calificados:

- Horacio Castronovo, a cargo de Obras Sanitarias Tandil.

- Nancy Enriquez, Coordinadora de los Centros Comunitarios, Secretaria de Desarrollo Social del Municipio de Tandil

- Graciela González Nogués, Dirección de Atención Primaria a la Salud, Municipio de Tandil.

Las entrevistas permitieron conocer las características generales del tendido de la red de agua y cloacas en la ciudad de Tandil, su cobertura actual y los proyectos futuros. Al mismo tiempo, la indagación se focalizó en los barrios o zonas más problemáticas, es decir aquellos que carecen de alguno o de ambos servicios.

En la Figura 53 se presenta el tejido urbano de la ciudad de Tandil, con la indicación de los barrios periféricos. La zona del Lago del Fuerte es también conocida como Don Bosco, debido al nombre de la avenida que la atraviesa.

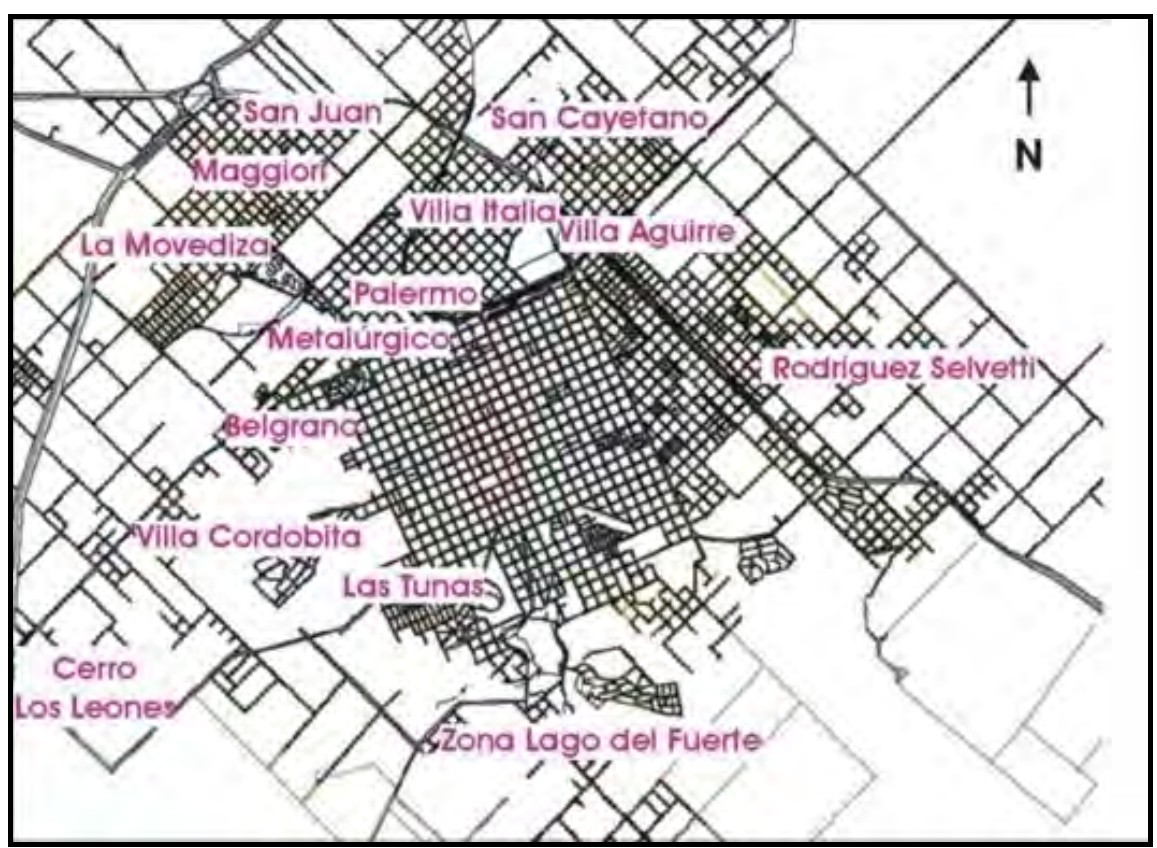

Figura 53. Ciudad de Tandil y ubicación de los barrios periurbanos. 
A partir de los datos relevados en entrevistas a informantes y en las observaciones a campo, se identificaron los barrios más problemáticos en relación al uso y explotación del recurso hídrico subterráneo (Tabla 16).

Cabe destacar que varios sectores periurbanos de bajo nivel socioeconómico, tales como Villa Cordobita, Las Tunitas y Cerro Leones, se ubican sobre las laderas de las sierras, lo cual dificulta y encarece el tendido de las redes. A pesar de estas limitaciones, dichas áreas presentan desde hace varios años, un constante crecimiento poblacional.

Otro sector en expansión corresponde a la zona de Don Bosco, en las cercanías del Lago del Fuerte, con la diferencia que en este caso la población involucrada es de mayor nivel socioeconómico.

Tabla 16. Barrios de la ciudad de Tandil con deficiencias de agua potable y servicios sanitarios.

\begin{tabular}{ccc} 
& \multicolumn{2}{c}{ Cobertura } \\
\cline { 2 - 3 } Barrio o sector & Agua potable & Red cloacal \\
\hline La Movediza & Parcial & Ausencia \\
Cerro Los Leones & Ausencia & Ausencia \\
San Cayetano & Total & Ausencia \\
Villa Laza (Barrio Metalúrgico) & Ausencia & Ausencia \\
Las Tunitas & Parcial & En construcción (2009) \\
Villa Cordobita & Ausencia & Ausencia \\
San Juan & Parcial & Ausencia \\
Villa Aguirre & Parcial & En construcción (2008 y 2009) \\
Zona Don Bosco & Ausencia & Ausencia
\end{tabular}

Por el contrario, los barrios Belgrano, Rodríguez Selvetti, Metalúrgico (a excepción de Villa Laza), Villa Italia, las zonas céntricas (denominadas Zona 11 y 12) poseen ambos servicios.

\subsection{Red de actores involucrados en la gestión del agua}

Los procesos de gestión de los recursos requieren la participación de actores, a los que Dourejeanni (2000) llama “actores del proceso de gestión”. Para el desarrollo de este apartado y siguiendo la metodología planteada por el mismo, se identificaron los actores involucrados en la gestión del recurso hídrico.

A partir de las variables establecidas por Dourejeanni (2002) y detalladas en el ítem 1.6 Marco Teórico Conceptual, se analizó el proceso de apropiación, explotación y uso 
del recurso hídrico en Tandil, caracterizado por su complejidad, dada la intervención de diferentes actores, que conforman una red interactiva.

Uno de los principales actores locales es el Municipio de Tandil, organismo público responsable de gestionar el uso de los recursos hídricos superficiales y subterráneos, así como de garantizar su protección, responsabilidad delegada por Obras Sanitarias de la Provincia de Buenos Aires en 1980 (Barranquero, 2005). De ese modo, el Municipio cuenta con un ente específico que funciona desde 1938, llamado Obras Sanitarias Tandil (OST), encargado de la distribución de agua potable a través de una red, del mantenimiento de los sistemas cloacales y pluviales, y del tratamiento de los efluentes cloacales en una planta ubicada al norte de la ciudad.

En algunos sectores de la ciudad, donde se han detectado problemas de contaminación en el acuífero freático, o en sitios donde es dificultoso perforar debido a la rocosidad, el Municipio de Tandil se encarga de abastecer a los pobladores con agua potable. La misma es transportada y distribuida mediante camiones cisterna desde OST. Este servicio es gratuito para los habitantes, pero no resuelve por completo sus necesidades de agua, debido a que el recurso es otorgado dos o tres veces por semana, en un determinado volumen, que a veces no es suficiente cuando la familia es numerosa.

Si bien la temática legal y normativa es de sumo interés al abordar la gestión del agua, no será objeto de análisis, pues no responde a los objetivos planteados. No existe legislación a nivel municipal sobre la explotación del recurso hídrico subterráneo por parte de actores públicos y privados (Latella, 2006), rigiendo la legislación provincial, especialmente el Código de Aguas Ley 12.257 y su Decreto Reglamentario 3511/07. El Código es un instrumento legal que tiene como objeto reglamentar, supervisar y vigilar todas las actividades y obras relativas al estudio, captación, uso, conservación y evacuación del agua. La Autoridad del Agua (ADA) se constituye a partir de dicha ley como entidad de aplicación de las funciones encomendadas al Poder Ejecutivo. Es un ente autárquico de derecho público y naturaleza transdiciplinaria y cuya organización y funcionamiento se dispone sobre la base de la descentralización operativa y financiera.

Otro organismo responsable de la normativa y el control es la Dirección Provincial de Saneamiento y Obras Hidráulicas (DIPSOH), encargada de la realización de proyectos y obras hidráulicas referidos al saneamiento ambiental y control de inundaciones de la Provincia de Buenos Aires.

En el ámbito económico-productivo, los habitantes de la ciudad de Tandil constituyen un conjunto que puede diferenciarse entre aquellos cubiertos por los servicios de agua potable y cloacas, los que acceden solamente al primero de ellos, y los restantes que carecen de ambos. 
En el primer caso, los usuarios que poseen ambos servicios no encuentran grandes dificultades en lo que se refiere al uso del recurso hídrico. Reciben el agua potable y desagotan sus efluentes a la red cloacal, abonando una tasa municipal. Cabe destacar que la existencia y funcionamiento de medidores del consumo de agua de red es limitada, por lo cual muchos usuarios abonan un monto fijo bimestral independientemente del volumen utilizado.

Los que no poseen dicho servicio, deben realizar sus perforaciones, recurriendo a otro grupo de actores económicos, constituido por perforistas. En algunos casos son los propios habitantes quienes las realizan, sobre todo en aquellos lugares donde la profundidad del nivel freático es somera.

Otro grupo de actores desde el punto de vista económico-productivo y tanto del ámbito local como externo, está conformado por las empresas que comercian y distribuyen agua y bebidas envasadas. A partir de la preocupación social en los últimos años por la calidad del agua, tanto de red como de pozo, el consumo de bebidas envasadas se ha incrementado, al mismo tiempo que la adquisición y utilización domiciliaria de equipos purificadores de agua a pequeña escala.

En las zonas no abastecidas por la red cloacal, se requiere la realización de pozos absorbentes, para la disposición de los efluentes domiciliarios, lo que implica la intervención de actores que se encargan de su construcción. Aquellos poseen diferentes características, algunos son más profundos o más anchos, otros tienen cámaras sépticas o decantadores ubicados previamente, así como algunos son construidos teniendo en cuenta la ubicación de la perforación para bombeo. La existencia de este tipo de pozos, genera en muchos casos la relación con otros actores económicos, que son los que se encargan de desagotarlos, mediante camiones conocidos como "atmosféricos". Esta tarea puede ser realizada por particulares, que luego deben llevar los efluentes a la planta de OST para su tratamiento.

Otro núcleo involucrado en la apropiación y uso del recurso hídrico subterráneo, está constituido por las actividades productivas que utilizan el agua para sus procesos. Incluye diversas industrias, algunas agrupadas en el Parque Industrial Tandil ubicado al NO de la ciudad, y muchas dispersas en el ejido urbano. Estas empresas en muchos casos generan efluentes y residuos que requieren tratamientos especiales, pero que muchas veces son dispuestos junto a los efluentes domiciliarios. Por otro lado, existen actividades que pueden impactar sobre la calidad del recurso hídrico subterráneo, como los criaderos de animales, ubicados en los barrios periféricos de la ciudad; las actividades agrícolas tanto en sectores periurbanos como rurales, que reciben aportes de agroquímicos y utilizan el agua para riego; los sitios de disposición de residuos sólidos, tanto el relleno 
sanitario manejado por una empresa como basurales espontáneos en diferentes sectores. Para una gestión integral del agua, estas actividades productivas deberían interesarse por prácticas sustentables en el uso del recurso, y deberían ser apoyadas por los actores gubernamentales.

Cuando la calidad del agua de bebida se deteriora, pueden ocurrir enfermedades de origen hídrico en quienes la consumen. Aquí interviene otro tipo de actores, tanto del ámbito público como privado, que incluye a los establecimientos y profesionales de la salud. En el ámbito público, pueden citarse el Hospital Municipal Ramón Santamarina, el Hospital de Niños Dr. Debilio Villegas, y las Salas de Atención Primaria a la Salud que se distribuyen en los barrios de la ciudad.

En los sectores que carecen de los servicios en cuestión, los habitantes se agrupan en Comisiones Vecinales para solicitar el abastecimiento y cuentan con representantes que se encargan de la gestión política de sus necesidades.

Otro actor de relevancia son los Centros Comunitarios barriales, que cuentan con trabajadores sociales y en muchos casos son intermediarios entre el ámbito gubernamental y los habitantes. Constituyen participantes activos en la gestión debido a que se encargan de realizar y difundir campañas de concientización sobre enfermedades hídricas. Además, en muchos casos distribuyen cloro para la desinfección de tanques y cañerías, y organizan charlas o encuentros con profesionales sobre la prevención de dichas enfermedades.

Por último, y en relación a la presente investigación, otro sector vinculado a la gestión del recurso hídrico, perteneciente al ámbito científico, es la Universidad Nacional del Centro de la Provincia de Buenos Aires, donde se encara el diagnóstico del agua subterránea en forma integral, así como el establecimiento de pautas generales para su gestión.

A continuación, en la Tabla 17, se sintetiza la red de actores y su nivel de gestión. 
Tabla 17. Actores involucrados en la gestión del agua en la ciudad de Tandil.

\begin{tabular}{cc} 
Actor & Nivel de gestión \\
\hline Municipio de Tandil & \\
Obras Sanitarias Tandil (OST) & \\
Entes gubernamentales provinciales o \\
nacionales (Ejemplos: ADA, DIPSOH) \\
Establecimientos de Salud & Normativo y de control \\
\hline Comisiones y agrupaciones vecinales & Político-social \\
Centros Comunitarios barriales & \\
\hline Usuarios & \\
Empresas comerciantes de agua y bebidas & \\
Actividades productivas & \\
Empresas de desagote de pozos & \\
Perforistas y constructores de pozos & Científico-ambiental \\
\hline Universidad Nacional del Centro de la \\
Provincia de Buenos Aires (UNCPBA)
\end{tabular}

\subsection{Caracterización socioeconómica del Barrio Cerro Los Leones}

El análisis del subsistema social a escala del Barrio Cerro Los Leones, fue posible a través de dos técnicas descriptas en el ítem Metodología. Por un lado, las encuestas sistematizadas efectuadas a los habitantes de 44 viviendas, cuya distribución se indica en la Figura 54. Por otro lado, las entrevistas a informantes calificados y actores claves en la gestión del agua, entre ellos:

- Lic. Maria Laura Shemi. Trabajadora Social del Centro Comunitario.

- Daniel Gamondi. Enfermero de la Sala de Atención Primaria a la Salud.

- Dra. Mariel Panozzi. Médica a cargo de la Sala de Atención Primaria a la Salud.

- Gloria Raffin. Vicepresidenta de la Comisión Vecinal del Barrio.

- Docentes, No Docentes y Directivos de la Escuela Secundaria Básica No 15, Escuela Primaria Básica № 4 y Jardín de Infantes No 915.

- Habitantes del barrio: Lina Elsa Poli y Oscar Furlan.

Cabe destacar el trabajo realizado, tanto de diseño del formulario de encuesta, como la realización de las mismas. Los pobladores fueron tomando confianza a medida que 
fueron visitados periódicamente en las oportunidades de los censos de perforaciones, facilitando la obtención de información. Las respuestas de los habitantes fueron variadas, sin bien en general la recepción fue muy buena, en algunos casos mostraron desinterés en la temática abordada, y en otros directamente no aceptaron ser encuestados. A partir del análisis e interpretación de la información relevada por este medio, fue posible caracterizar la situación social del barrio y conocer los modos de explotación y uso del agua subterránea, sin contar con información o estudios previos relacionados.

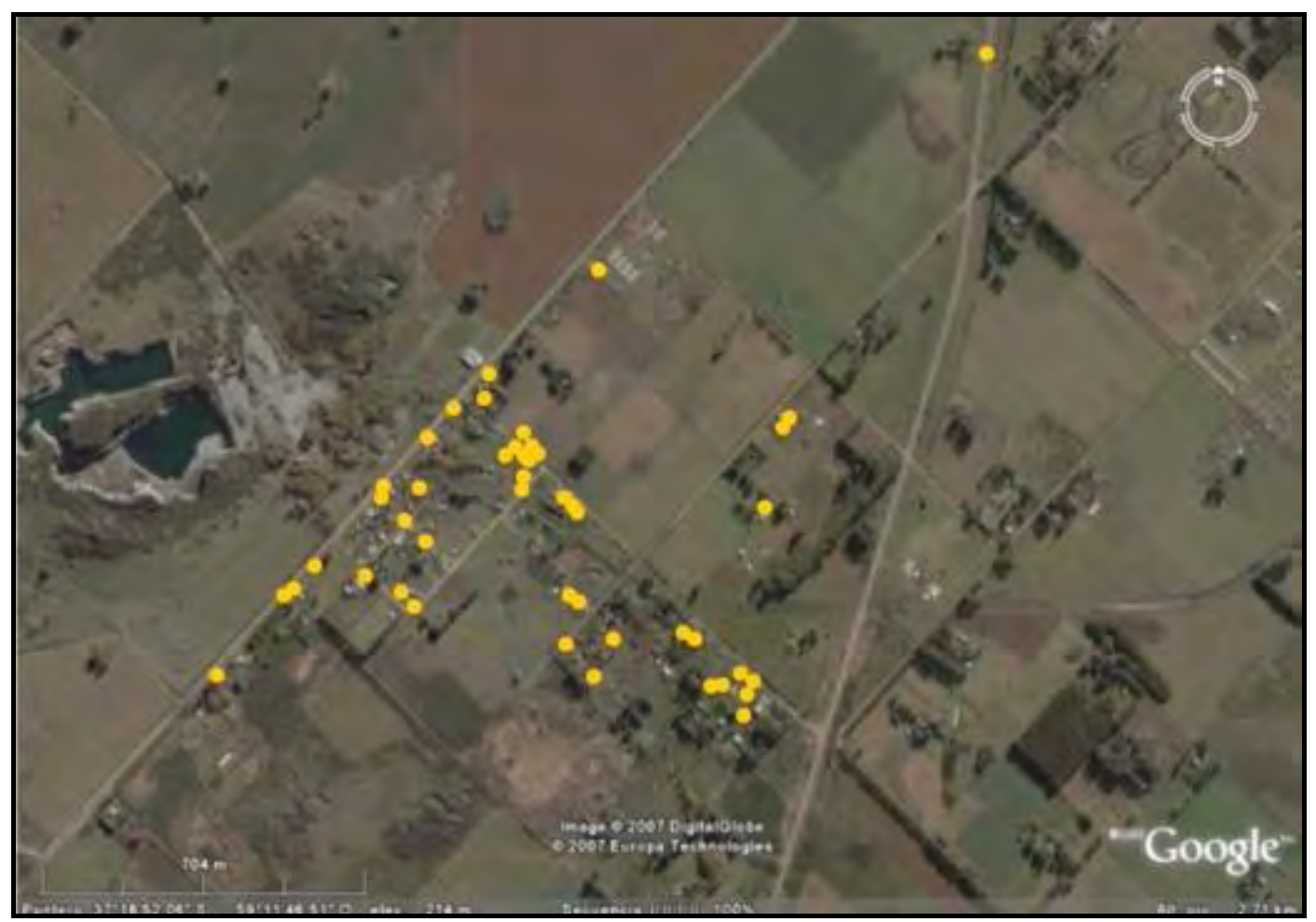

Figura 54. Ubicación de las viviendas encuestadas.

Según las estimaciones del Centro Comunitario, en el año 2008 existían aproximadamente 300 habitantes, aunque ese número es creciente debido a la frecuente y actual instalación de familias. Muchas de ellas formadas por inmigrantes de países limítrofes, especialmente de Bolivia, quienes son empleados en la zona, principalmente en la fabricación de ladrillos.

La población estudiada se constituyó principalmente por adultos. El 30\% corresponde a niños y adolescentes que concurren a establecimientos educativos ubicados tanto en el barrio como en otros sectores de la ciudad.

La situación socio-económica es compleja. Sólo el 37\% de la población encuestada respondió que se encontraba trabajando, muchos de los cuales lo hacen fuera del barrio. Las actividades económicas desarrolladas en el barrio son diversas. Existen hornos de 
fabricación de ladrillos, que extraen suelo circundante para su uso como materia prima. También se ubican emprendimientos apícolas, pequeños comercios minoristas de alimentos, algunos servicios, actividades agropecuarias extensivas e intensivas, destacándose entre estas últimas criaderos de cerdos y tambos.

Se evidenció una alta presencia de familias de bajos ingresos, que habitan en viviendas con deficiencias básicas, y en menor proporción de clase media, con mejor situación económica. Las edificaciones son bajas y separadas entre sí. La mayoría son construcciones antiguas, que permanecen de la época de auge de la actividad minera, fabricadas con diversos materiales, combinando madera, chapas y ladrillos. Coexisten con otras, de mejor calidad y con menores deficiencias. Algunos ejemplos de viviendas del barrio se indican en las Figuras 55 a 58.
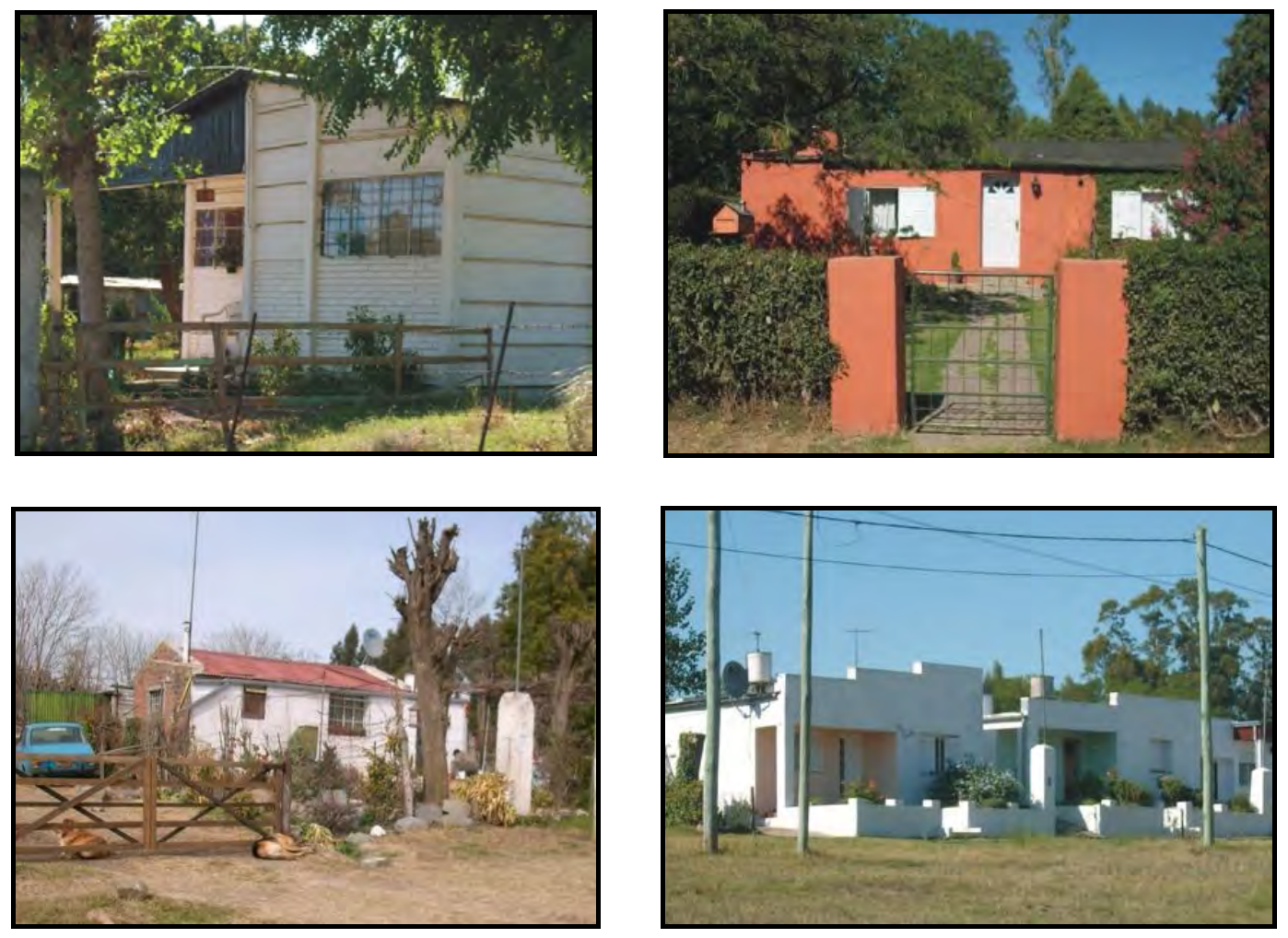

Figuras $55-56-57$ - 58. Viviendas del Barrio Cerro Los Leones.

Existen centros de referencia barriales, donde la población concurre a realizar actividades, satisfacer necesidades o consultar ante problemáticas sociales, económicas y de salud. Dos de ellos son la Sala de Atención Primaria a la Salud y el Centro Comunitario, reflejados en las Figuras 59 y 61 . La Sala realiza la atención primaria, derivando los pacientes hacia el Hospital local en caso de ser necesario. Cuenta con un enfermero y una médica que asiste dos veces por semana. El Centro Comunitario incluye varias funciones, por un lado se encarga de distribuir alimentos a las familias carenciadas, y por el otro es el lugar de encuentro para diversas actividades y talleres de capacitación. 


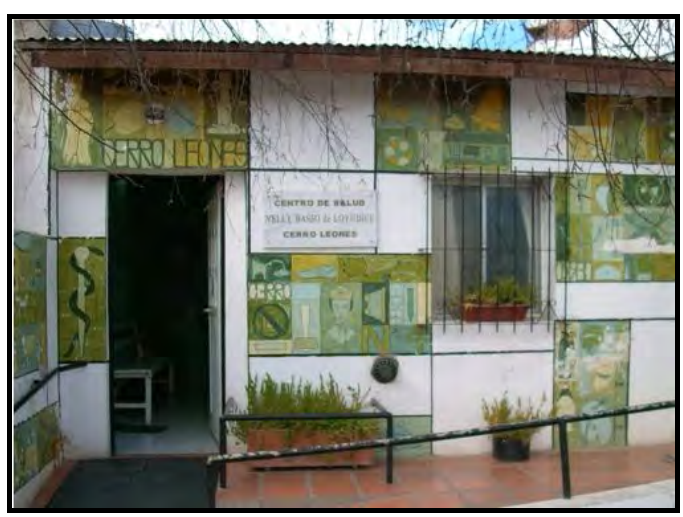

Figura 59. Sala de Atención Primaria a la Salud.

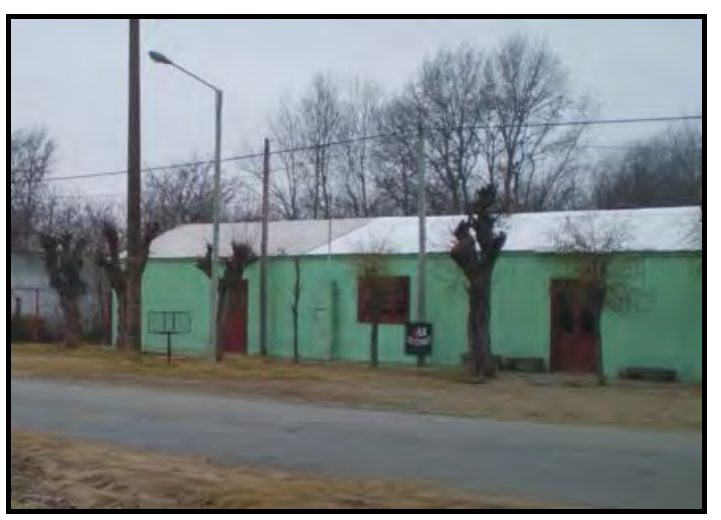

Figura 60. Bar El Cerro.

Otros lugares de reunión y relaciones sociales lo constituyen el Club Figueroa, dentro del que se sitúa la Biblioteca barrial, así como los establecimientos educativos y el Bar El Cerro, ilustrado en la Figura 60. Este último se localiza justamente frente al Cerro Los Leones.

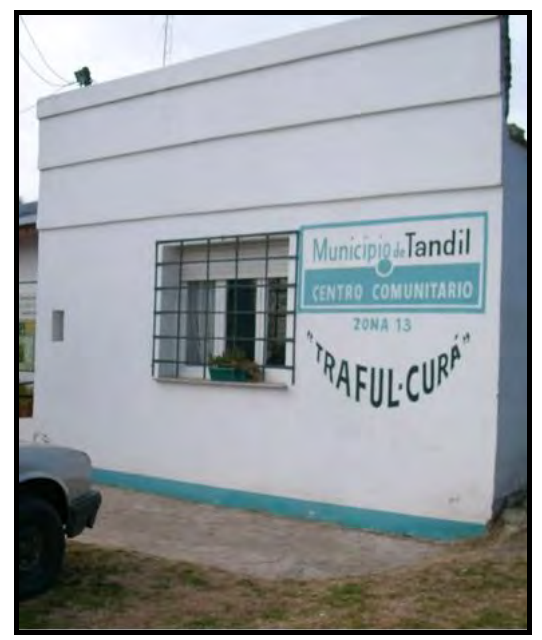

Figura 61. Centro Comunitario Zona 13.

Se recabaron antecedentes del año 2006 sobre análisis bacteriológicos de muestras de agua provenientes de viviendas del barrio, a partir de los cuales se han detectado bacterias patógenas en niveles superiores a lo recomendado por el Código Alimentario Argentino. A partir de esa situación, desde la Dirección de Bromatología, se puso en marcha una serie de charlas, sobre los efectos posibles del consumo de agua en el barrio y las medidas de limpieza y desinfección de los tanques de almacenamiento de agua. Además, el Centro Comunitario hizo entrega de folletos educativos, enviados por el Ministerio de Salud de la Provincia de Buenos Aires, en los cuales se explican las medidas que deben tomarse para consumir el agua con presencia de patógenos. Posteriormente, el Municipio otorgó dosis de cloro a los habitantes, pero muchos de ellos 
no recibieron información sobre cómo utilizarlo, no alcanzándose los resultados esperados.

Los establecimientos educativos intervinieron activamente en la prevención y toma de medidas. Los alumnos de la Escuela Primaria Básica $N^{\circ} 4$ participaron en la Feria de Ciencias con un trabajo sobre la aptitud de agua para consumo humano en el barrio.

La señora Gloria Raffin, representante de la Comisión Vecinal local, planteó que uno de los objetivos primordiales que persigue su grupo de trabajo consiste en el abastecimiento de agua potable para el barrio. La Comisión pidió al gobierno local la extensión del servicio desde un barrio cercano, recibiendo como respuesta que el proyecto de aprovisionamiento estaba siendo analizado.

Los pobladores más antiguos atestiguaron sobre el despoblamiento que ha sufrido la zona, luego del cierre de la cantera. El abandono de la misma y la cava resultante se observan en las Figuras 62 y 63. Lina Elsa Poli, que ha vivido sus 85 años en el barrio, comentó sobre la gran densidad poblacional, diciendo "estaba lleno de casas, desde la loma hasta abajo", lo cual se debía principalmente a la cantidad de empleados mineros. Por su parte, Oscar Furlán que trabajó en la cantera durante 37 años, comentó que en 1915 existían alrededor de 1000 empleados, mientras que en 1955 quedaban sólo 230. En 1980 se realizó el despido de 70 empleados, entre los que estuvo incluido, quedando sólo 11 activos. Posteriormente, sobrevino el cierre definitivo en la década de 1990.

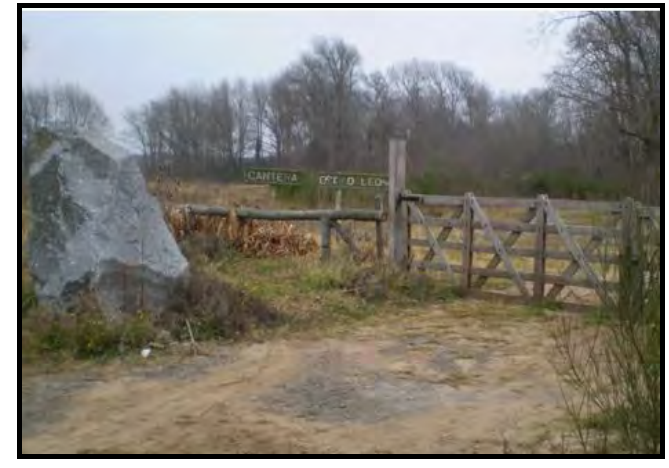

Figura 62. Acceso a la cantera abandonada Cerro Los Leones.

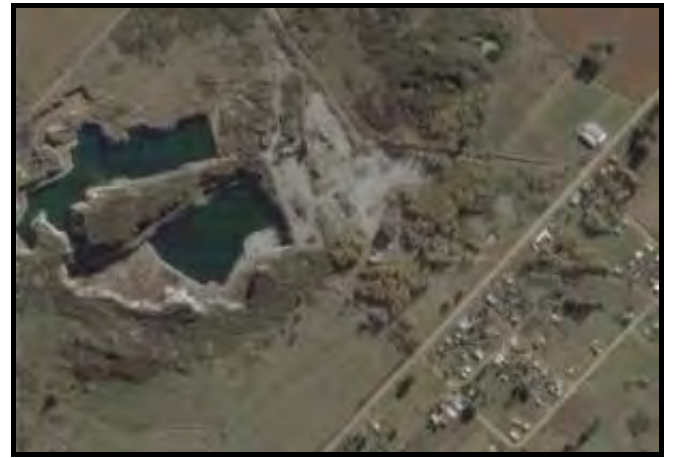

Figura 63. Cava de la cantera Los Leones. Fuente: Google Earth. 


\subsection{Situación relativa a la salud}

En relación a los antecedentes de análisis bacteriológicos, las encuestas informaron que el $43 \%$ de la población nunca ha realizado los mismos en muestras de sus perforaciones. El resto ha recibido información a través de análisis efectuados por la Dirección de Bromatología del Municipio de Tandil, gestionados en la mayoría de los casos por el Centro Comunitario barrial. Se han recabado informes de análisis que indicaron presencia de una o más bacterias por encima de los límites establecidos por el Código Alimentario Argentino, evidenciando la falta de aptitud para consumo humano. Sin embargo, sólo el $25 \%$ de la población respondió haber sufrido algún tipo de enfermedad posiblemente relacionada con el agua, tales como diarreas, vómitos, problemas intestinales, entre otros.

La entrevista al enfermero de la Sala de Salud del barrio, permitió conocer la existencia de un registro de epidemiología, que es de carácter incompleto, debido a que muchas afecciones son derivadas directamente al Hospital Municipal Ramón Santamarina de la ciudad de Tandil. Del total de habitantes del barrio, han asistido solamente alrededor de 70 personas a la Sala de Atención Primaria, alcanzándose a alrededor de 250 prestaciones por mes. La mayoría de ellas correspondieron a controles periódicos de personas mayores, embarazadas o niños.

A través del encuentro con la médica Mariel Panozzi, se conocieron detalles acerca del registro de enfermedades, especialmente de aquellas vinculadas con el agua. Según la médica, las patologías posiblemente relacionadas y predominantes en el sector de estudio, fueron parasitosis y diarreas. En la Tabla 18 se indican los registros para el período de desarrollo de esta investigación, entre el 01/01/2007 al 31/12/2008.

Tabla 18. Casos de diarreas y parasitosis durante 2007 y 2008.

(Fuente: Sala de Atención Primaria a la Salud del Barrio Cerro Los Leones).

\begin{tabular}{c|cc} 
Edades (años) & Diarreas & Parasitosis \\
\hline$<1$ & 1 & 3 \\
$1-4$ & 5 & 9 \\
$5-9$ & 2 & 11 \\
$10-14$ & 1 & 3 \\
$15-24$ & 1 & 5 \\
$25-34$ & 2 & 3 \\
$35-44$ & 1 & 5 \\
$45-64$ & 0 & 1 \\
$\geq 65$ & 3 & 0 \\
Total & 16 & 40
\end{tabular}


Los parásitos más comúnmente detectados fueron los oxiuros y, en menor medida, giardias. Cabe aclarar que los casos de parasitosis incluyeron tratamientos familiares, es decir que si un integrante de la familia presenta la patología, toda la familia recibió tratamiento preventivo, incrementando el número de casos.

En la Sala de Atención Primaria de la Salud habitualmente se confecciona una planilla denominada Informe epidemiológico semanal, que debe remitirse con esa frecuencia a la Dirección Provincial de Medicina Preventiva del Ministerio de Salud de la Provincia de Buenos Aires. Incluye un ítem referido a las enfermedades de transmisión hídrica, como cólera y fiebre tifoidea y también la Hepatitis, que puede relacionarse con el agua. Los casos de hepatitis, como enfermedad viral, no son registrados en los centros de salud barrial, sino exclusivamente en esas planillas. Además, desde las Salas de Salud se las informa como enfermedades virales, sin llegar a detectar qué tipo de virus se trata, pudiendo ser tanto gripe como hepatitis. Circunstancia esta que vuelve difícil el establecimiento de indicadores relacionados a enfermedades hídricas.

El seguimiento temporal y análisis de estas planillas no se ha llevado a cabo en el barrio, sino que directamente se remiten al ámbito provincial previo paso por el Municipio. Estos registros no poseen rigor, debido a que gran parte de la población del barrio asiste a otros establecimientos de salud distintos de la Sala de Atención Primaria barrial, especialmente el Hospital Ramón Santamarina o médicos particulares.

La médica planteó su interés en realizar estudios comparativos de los registros epidemiológicos en distintos barrios y parajes rurales, lo cual actualmente se ve dificultado porque en numerosos centros de salud no tienen computadora o la han obtenido recientemente, y dicha carencia les impide registrar los casos en el software adecuado.

\subsection{Condiciones de explotación y uso del recurso hídrico}

En lo referente a la utilización del agua para bebida, toda la población se abastece del recurso hídrico subterráneo. La Figura 64 indica que el 75\% lo realiza directamente a través de perforaciones o pozos, mientras que el $5 \%$ corresponde a quienes reciben agua mediante camiones cisternas, debido a problemas de las perforaciones o ausencia de las mismas. El servicio de entrega de agua es brindado semanalmente en forma gratuita por OST, obteniendo el recurso a partir de perforaciones municipales ubicadas en otro sector de la cuenca del arroyo Langueyú. Por otro lado, del total de la población que utiliza el agua subterránea, el $18 \%$ responde que no la consume, sino que adquieren bebidas envasadas. 


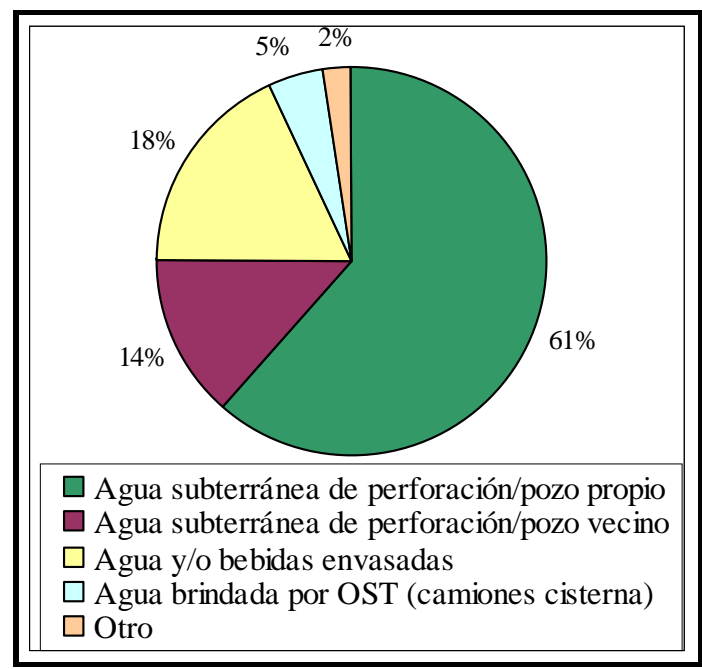

Figura 64. Fuentes de agua para bebida humana.

Cabe destacar que no toda la población estudiada explota el acuífero subterráneo a través de perforaciones propias, sino que el $18 \%$ de las familias indicó que comparten la misma con la vivienda vecina. Tal es el caso ilustrado en la Figura 65, donde dos familias utilizan el mismo bombeador ubicado sobre un antiguo jagüel.

La mayoría de los equipos de extracción de agua relevados tienen bombeadores instalados sobre la superficie del terreno, y solamente el $10 \%$ bombas sumergidas. Generalmente se encuentran protegidos de la contaminación superficial mediante estructuras o tapas, aunque se observaron numerosas construcciones deficientes, incluso con pérdida de aceite de las bombas. En muchos casos, los antiguos jagüeles fueron modificados con la instalación de bombeadores, como puede observarse en la Figura 66.

En el $35 \%$ de los hogares se evidenció probable contaminación, debido principalmente a la deficiente cobertura o inexistencia de tapa sobre la boca del pozo, así como por la presencia de animales y disposición de residuos en las cercanías de la perforación.

Un factor importante para la protección sanitaria, es la presencia de cañerías de encamisado en las perforaciones. Cuando se interrogó sobre este tema, muchos de los encuestados desconocieron la existencia o las características de dicho sistema. Se pudo observar que solamente el $30 \%$ de las perforaciones poseen encamisado (Figura 67). 


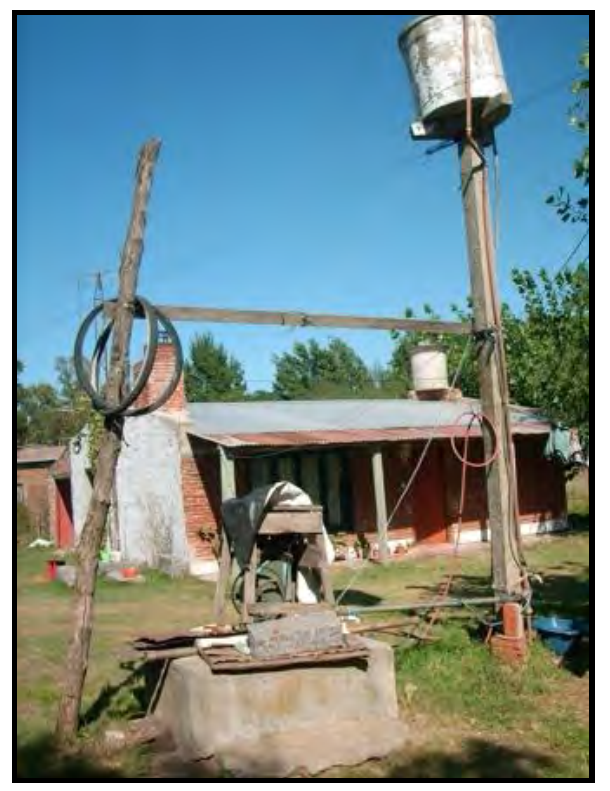

Figura 65. Pozo compartido por dos viviendas.

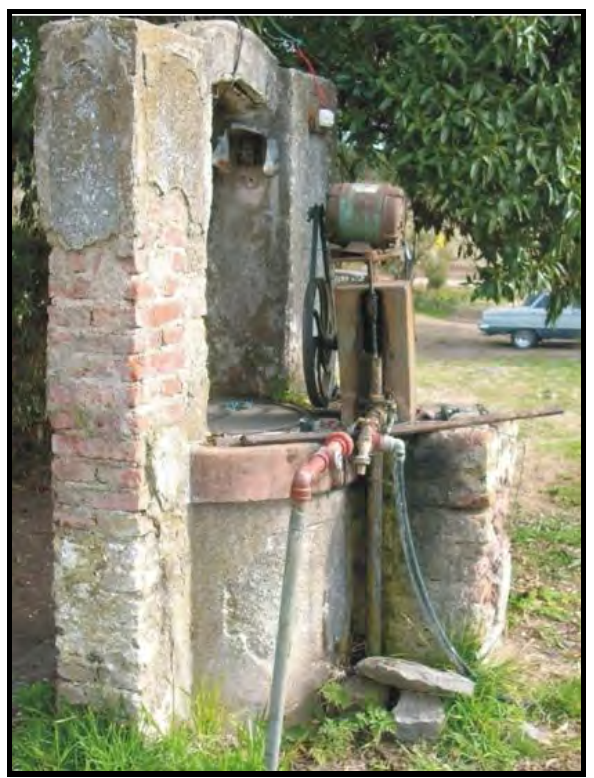

Figura 66. Antiguo jagüel con bombeador.

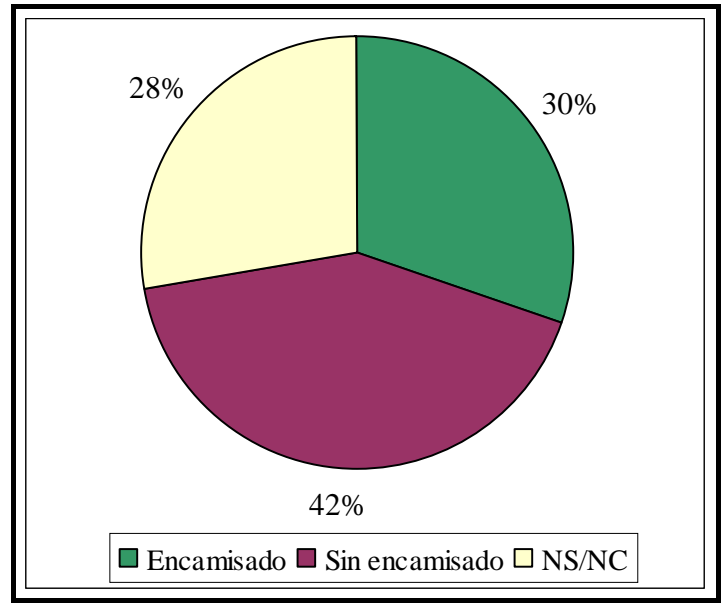

Figura 67. Presencia de cañerías de encamisado.

Con respecto al conocimiento y realización de saneamiento en la perforación (Figura 68), las encuestas indicaron que el $67 \%$ no realiza ningún tipo de desinfección, el $26 \%$ lo hace pero sin información clara, y el resto simplemente desconoce de qué se trata. En cambio, la mayoría respondió que realiza desinfección de tanques y cañerías, alcanzando el 75\% (Figura 69).

En las labores de desinfección de la perforación, tanque y cañerías, es fundamental que los habitantes accedan a la información necesaria sobre cómo realizarlas, ya sea a través de los medios de comunicación locales, gráficos, radiales ó televisivos, así como de los canales de difusión barriales, principalmente la Sala de Atención Primaria a la Salud, el Centro Comunitario y los establecimientos educativos. La consulta acerca de la 
difusión de instrucciones respecto a dicho saneamiento, permitió saber que solamente el $13 \%$ de los encuestados las recibieron.

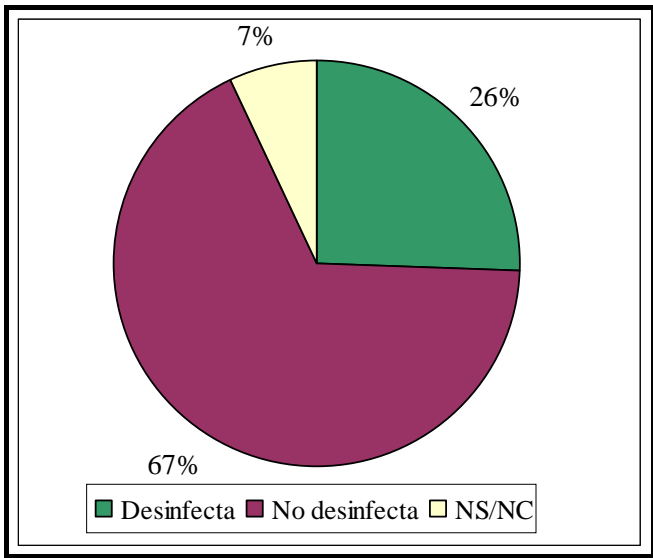

Figura 68. Desinfección de pozos.

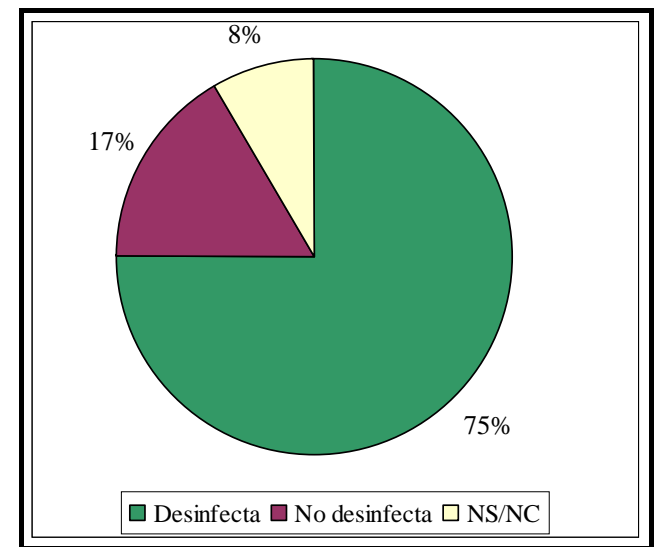

Figura 69. Desinfección de tanques y cañerías.

Cabe destacar las deficiencias detectadas en los sistemas de almacenamiento y distribución del agua. La Figura 70 muestra que el 77\% de las viviendas poseen tanques, ubicados sobre los techos o en estructuras elevadas. El resto comparte el tanque con un vecino, almacena el agua en recipientes o la acarrea desde la perforación. Las cañerías, en muchos casos, se ubican en el exterior de las viviendas (Figuras 71 y 72). El 32\% no posee cañerías subterráneas, es decir que utilizan para su distribución sistemas aéreos, generalmente caños o mangueras, ambos de plástico. Por otro lado, algunas viviendas poseen sistemas de distribución sólo en un sector, generalmente en la cocina, sin tener abastecido el baño.

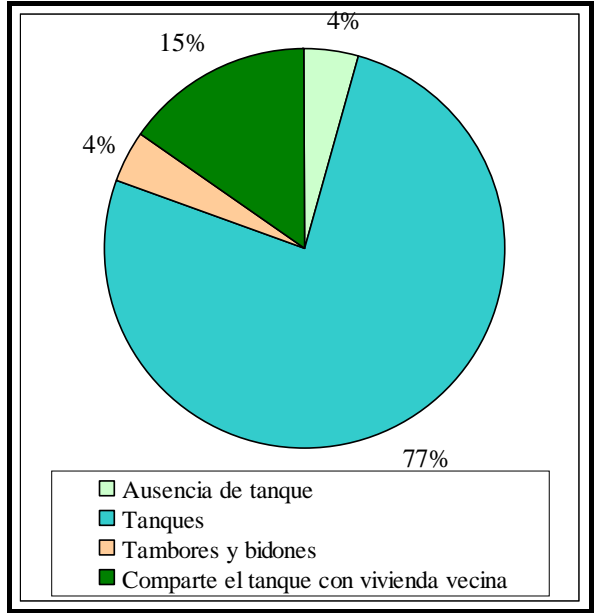

Figura 70. Almacenamiento del agua.

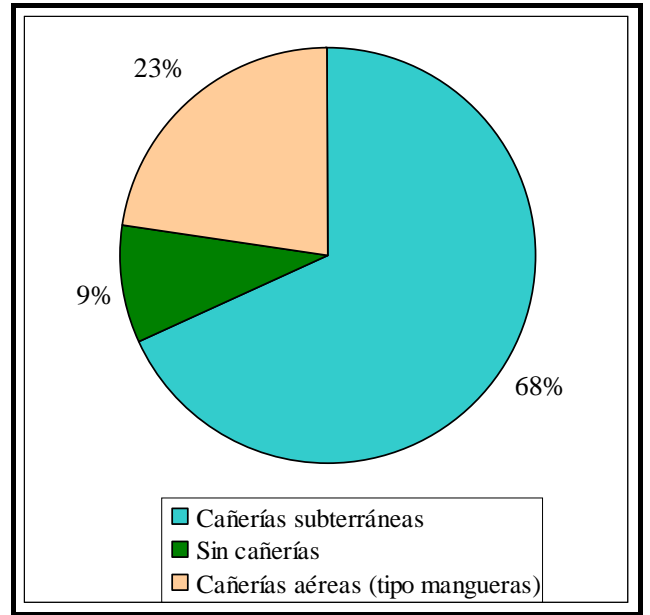

Figura 71. Sistemas de distribución de agua. 


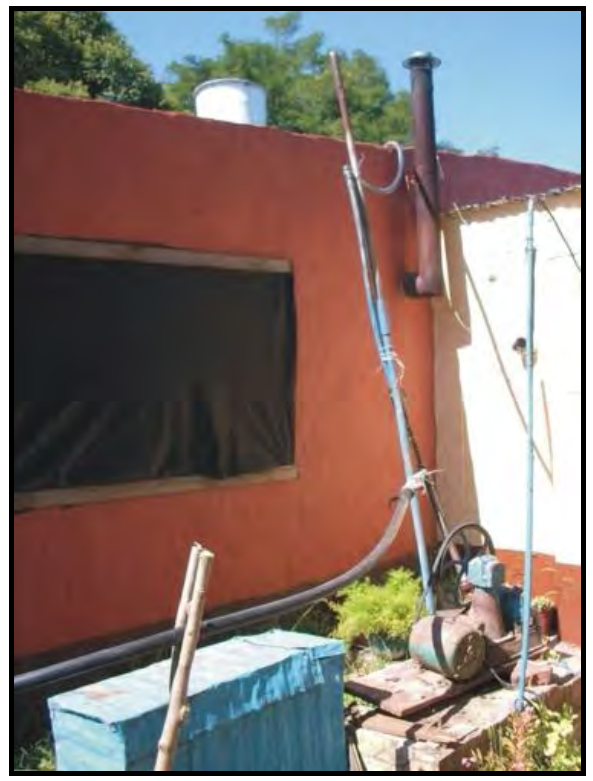

Figura 72. Cañerías de distribución de agua.

En forma simultánea a la carencia de red de agua potable, las casas del barrio Cerro Los Leones no poseen red cloacal, por lo cual vierten sus aguas negras principalmente en pozos absorbentes. La Figura 73 demuestra que el $76 \%$ de los hogares dispone sus excretas en dichos pozos, aunque únicamente el $20 \%$ respondió que posee una cámara séptica previa, permitiendo una mejor separación de los sólidos. El resto utiliza letrinas, baños precarios instalados fuera de las viviendas (Figura 74).

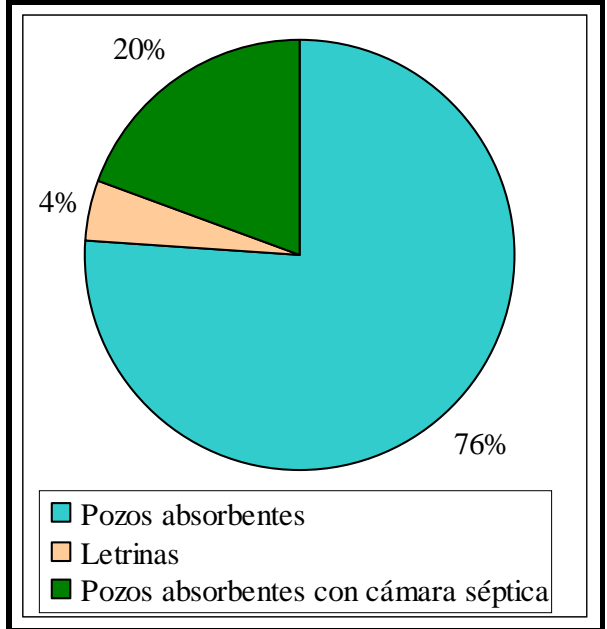

Figura 73. Sistemas de disposición de efluentes domiciliarios.

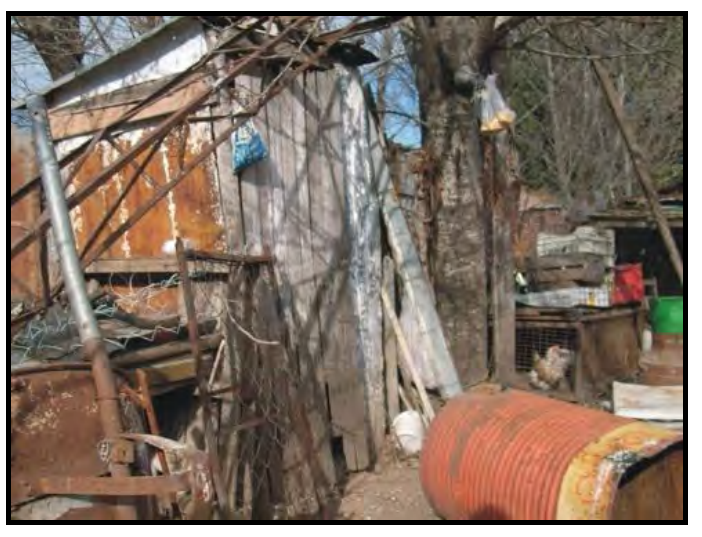

Figura 74. Baño tipo letrina.

En muchos casos el estado de los pozos absorbentes y letrinas denota su falta de mantenimiento. A esto se suma que la mayoría de los habitantes desconoce las 
características constructivas de los mismos, observándose pozos desmoronados y otros con coberturas deficientes (Figuras 75 y 76).

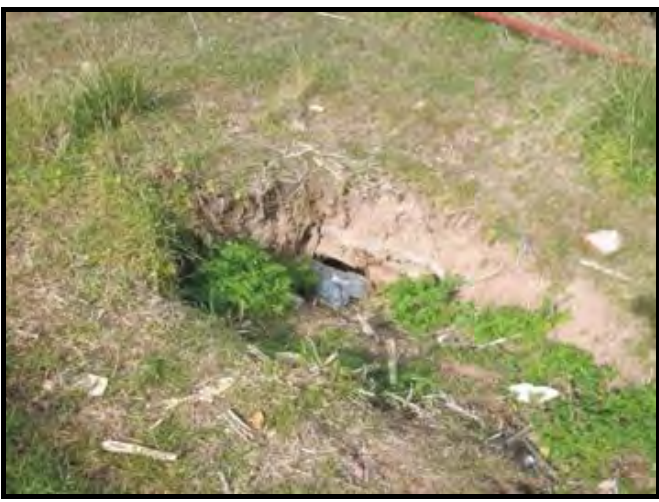

Figura 75. Pozo absorbente con evidencias de desmoronamiento.

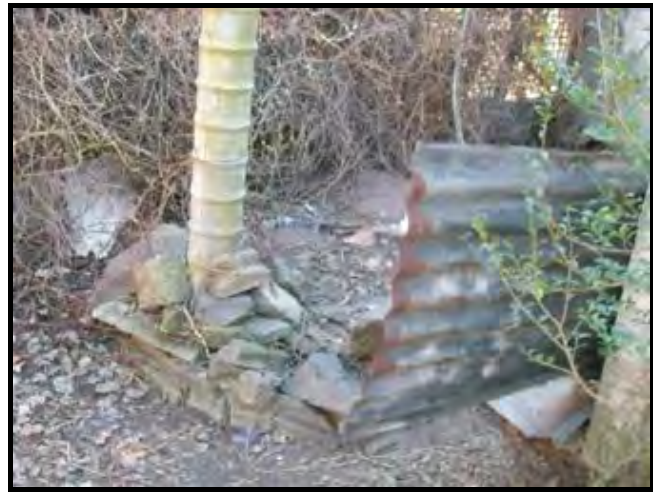

Figura 76. Cobertura deficiente de un pozo absorbente.

La deficiente construcción de los sistemas de disposición de efluentes, incluyendo las excretas humanas, conlleva a su uso inadecuado y posibilita la generación de focos de contaminación (CoFAPyS, 1993). Por consiguiente, es importante tener en cuenta la contaminación inducida por los efluentes cloacales, los que infiltran hacia las aguas subterráneas, afectando directamente a las perforaciones de bombeo. En el área de estudio se registran casos donde el pozo absorbente se encuentra en contacto con el nivel freático, tal como se observa en la Figura 77, especialmente en la zona baja del barrio. Ambos pozos pueden comunicarse a través del flujo subterráneo, con lo cual la contaminación orgánica y biológica de origen fecal es de gran importancia.

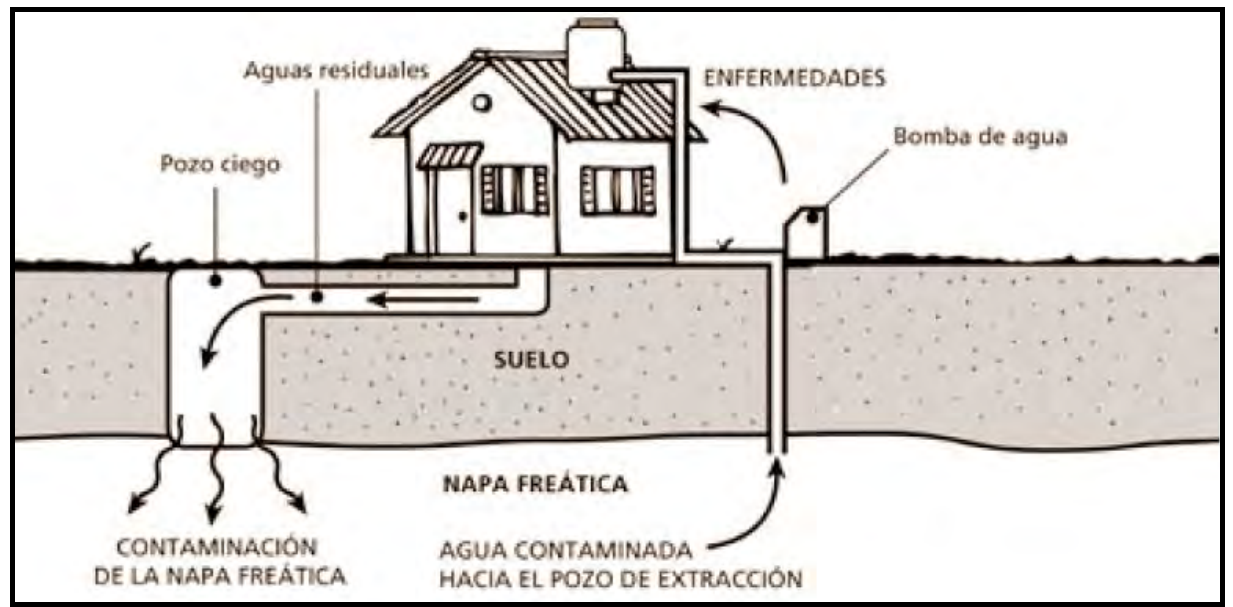

Figura 77. Contaminación del agua subterránea por un pozo absorbente.

(Fuente: Mariñelarena, 2006).

Se ha prestado especial interés a la distancia existente entre las perforaciones de bombeo de agua y los pozos de disposición de efluentes cloacales. Diferentes autores han 
establecido recomendaciones, entre ellos Romero (1970) indica las distancias necesarias entre el sitio de captación y el foco contaminante, en relación al tipo de material constituyente tanto de la zona no saturada como la saturada. El mismo autor establece distancias de seguridad entre las perforaciones domésticas y distintos sistemas de vertido de efluentes, indicando un valor de 30 metros de separación respecto a los pozos de infiltración. Según CoFAPyS (1993) el distanciamiento mínimo recomendado entre las perforaciones de captación de agua para consumo humano y los pozos absorbentes es de 25 metros.

Considerando estos valores, se destaca que menos del $20 \%$ de los casos cumplen las recomendaciones. Asimismo, en el $82 \%$ de las viviendas la distancia fue menor a 25 metros, y en $72 \%$ fue incluso inferior a 15 metros, como se indica en la Figura 78.

Las distancias recomendadas no deben ser aplicadas uniformemente a cualquier área, sino que se requiere la consideración de las características geohidrológicas. En el caso del barrio en estudio, cabe tener en cuenta que existen sectores con rocosidad a escasa profundidad (medio fisurado), pudiendo requerirse otro tipo de medidas.

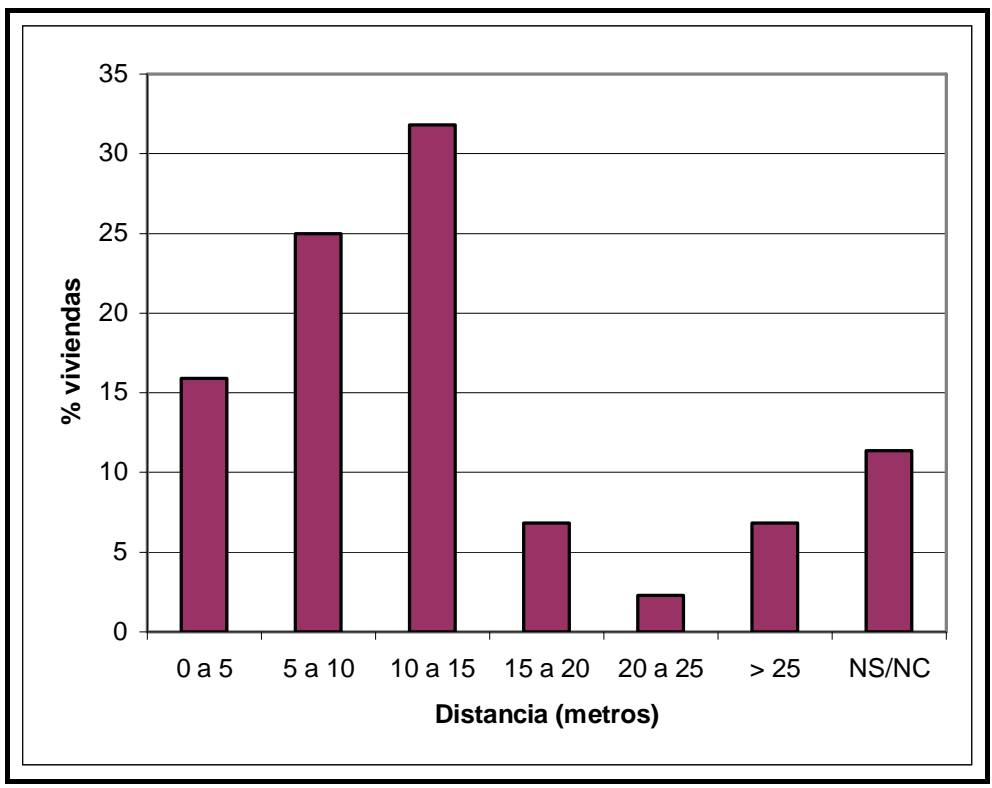

Figura 78. Distancias entre perforaciones y sitios de disposición de efluentes.

\subsubsection{Características de las perforaciones de la red de medición y muestreo}

En la Tabla 19 se indican las características más relevantes de las perforaciones y pozos de captación de agua considerados en la red de medición y muestreo. Se detalló para cada una el propietario, el tipo de obra o pozo, su profundidad (dato informado, no medido), y algunas cuestiones básicas del diseño y protección. 
La mayoría de los pozos son perforados y presentan bombeadores colocados en la superficie. Además, las profundidades generalmente no superan los 15 metros. Las cañerías de encamisado están ausentes en casi todas las perforaciones, excepto las construidas recientemente.

Con respecto a la protección superficial, se ha considerado la existencia de tapa o cobertura, así como también la presencia de residuos o animales en los alrededores. A partir de allí, se clasificó, en una escala cualitativa, la protección en muy buena, buena, regular o mala, en función de su menor a mayor posibilidad de permitir la contaminación del sistema subterráneo. De ese modo, el $78 \%$ de las perforaciones fueron clasificadas como regulares y malas, debido a que se ubican cercanas a animales o residuos o se encuentran directamente expuestas al ingreso de las precipitaciones, como son las perforaciones $\mathrm{N}^{\mathrm{o}} 2$ y 13. También se evidenció ingreso de aceite del bombeador al pozo, como los casos $\mathrm{N}^{\mathrm{o}} 12,14$ y 18. En algunos sitios, las estructuras de apoyo de los bombeadores y de las cañerías son deficientes y débiles, como lo muestran las Figuras 80, 83 y 93.

En cuanto a la distancia a los pozos absorbentes, se tuvieron en cuenta tanto los ubicados en el terreno propio como en los vecinos. Así, se determinó que todas las perforaciones de la red de medición se encuentran a menos de 25 metros de algún pozo absorbente, mientras que más del $80 \%$ de las mismas, no superan los 15 metros de distanciamiento.

Puede observarse, que las 18 perforaciones de la red de medición y muestreo representan claramente lo descrito anteriormente, en cuanto a las condiciones de explotación del agua subterránea en el Barrio Cerro Los Leones.

Tabla 19. Características de las perforaciones de la red de muestreo.

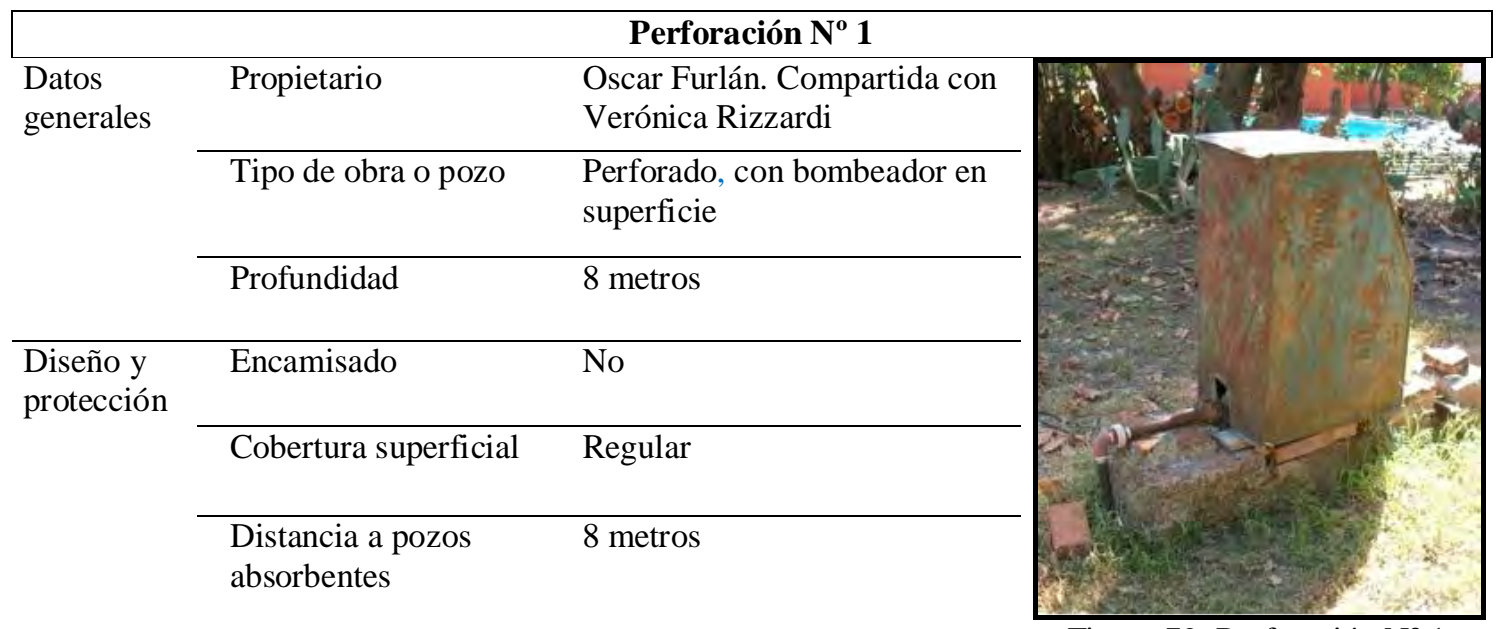

Figura 79. Perforación $\mathrm{N}^{\circ} 1$ 


\begin{tabular}{lll|}
\hline \multirow{2}{*}{$\begin{array}{l}\text { Datos } \\
\text { generales }\end{array}$} & Propietario & $\begin{array}{l}\text { Karina Ravena. Compartida } \\
\text { con Mariela Rodriguez }\end{array}$ \\
\cline { 2 - 4 } & Tipo de obra o pozo & $\begin{array}{l}\text { Jagüel cavado, con } \\
\text { bombeador en superficie. }\end{array}$ \\
\cline { 2 - 4 } Profundidad & 13 metros \\
protección & Encamisado & No \\
\cline { 2 - 3 } & Cobertura superficial & Mala \\
\cline { 2 - 3 } & $\begin{array}{l}\text { Distancia a pozos } \\
\text { absorbentes }\end{array}$ & 9 metros
\end{tabular}

Figura 80. Perforación $\mathrm{N}^{\circ} 2$

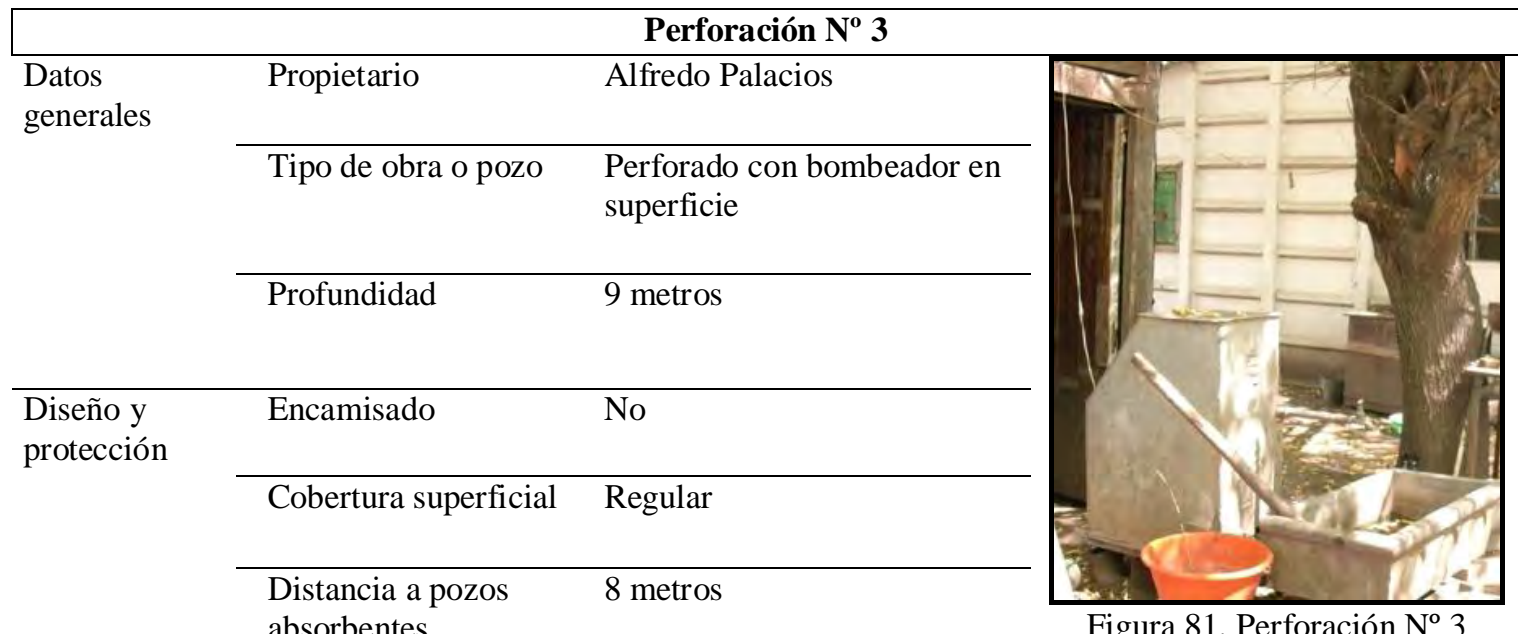

\section{Perforación $\mathrm{N}^{\circ} 4$}

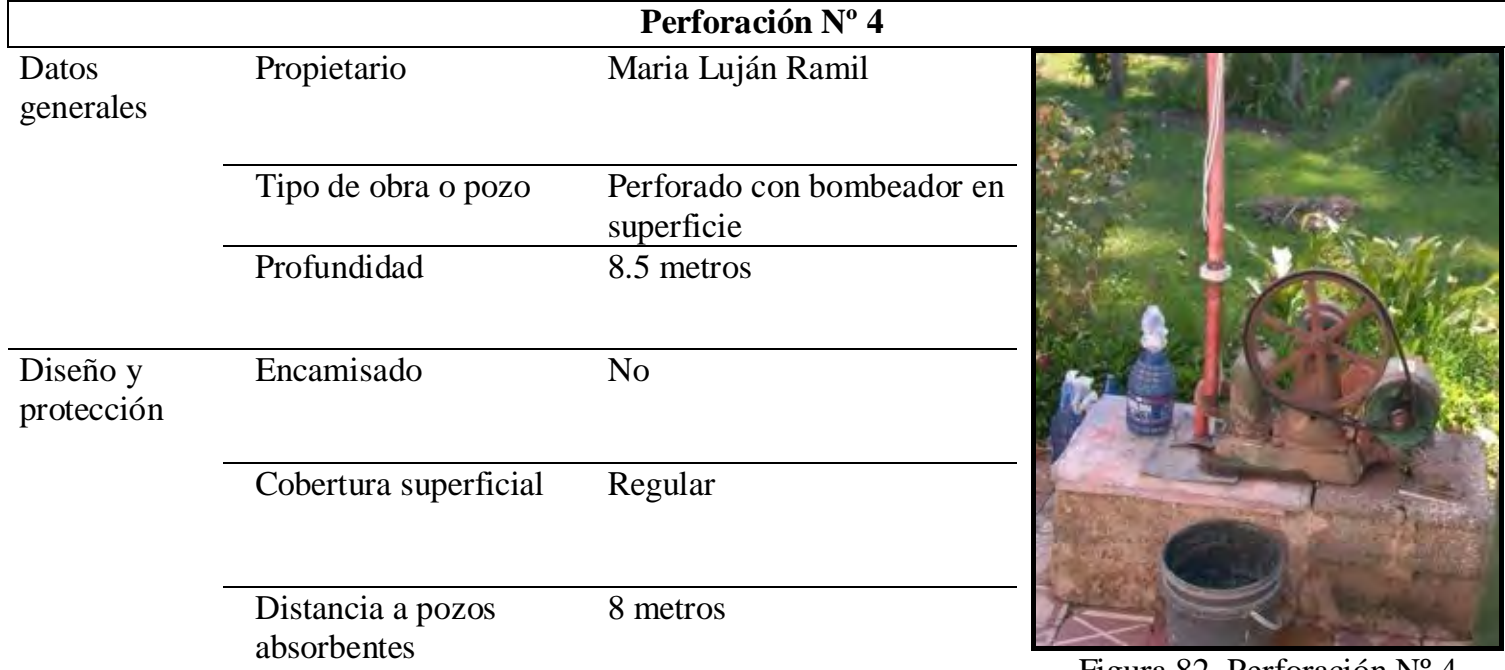

Figura 82. Perforación $\mathrm{N}^{\circ} 4$ 


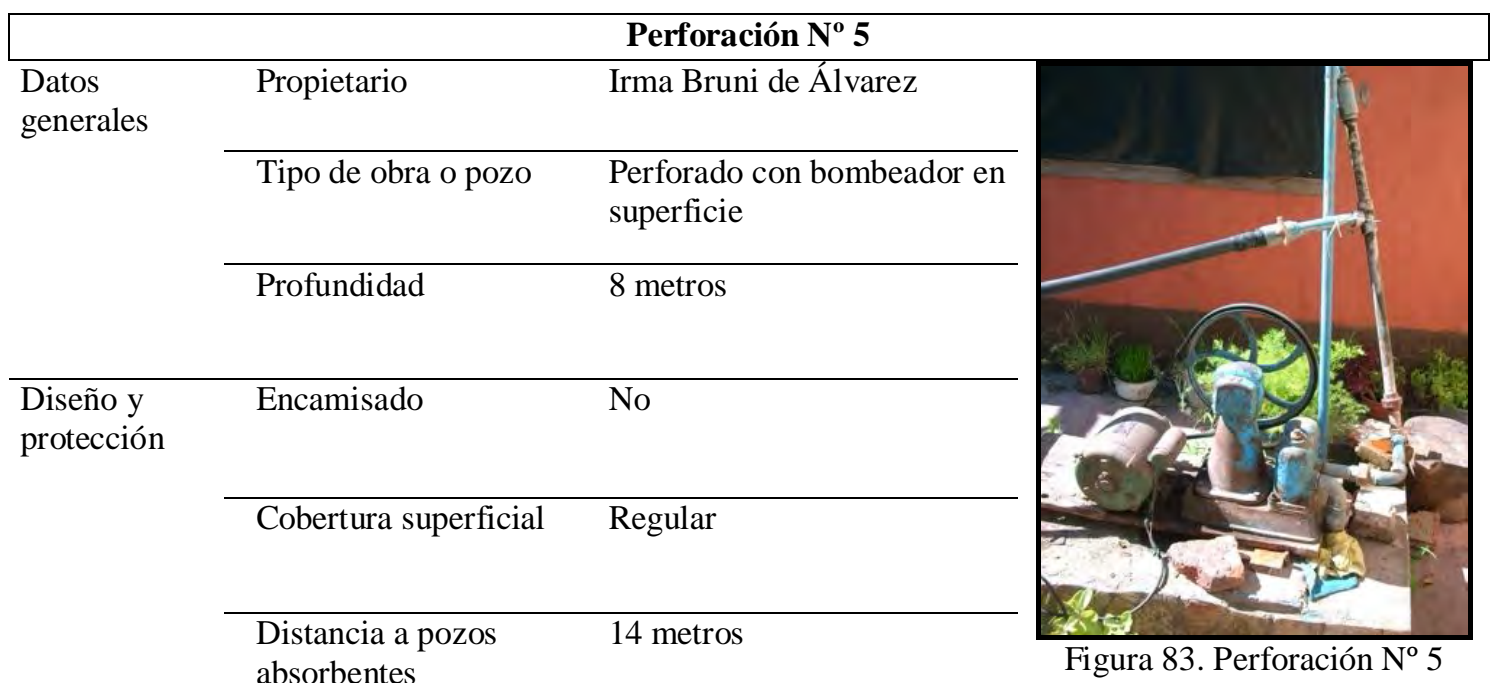

\begin{tabular}{|lll}
\hline & \multicolumn{1}{c}{ Perforación $\mathbf{N}^{\mathbf{0}} \mathbf{6}$} \\
\hline $\begin{array}{l}\text { Datos } \\
\text { generales }\end{array}$ & Propietario & Gloria Raffin \\
\cline { 2 - 3 } & Tipo de obra o pozo & $\begin{array}{l}\text { Perforado con bombeador en } \\
\text { superficie }\end{array}$ \\
\hline
\end{tabular}

Profundidad 12 metros

\begin{tabular}{lll|}
\hline $\begin{array}{l}\text { Diseño y } \\
\text { protección }\end{array}$ & Encamisado & No \\
\cline { 2 - 3 } & $\begin{array}{l}\text { Cobertura } \\
\text { superficial }\end{array}$ & Regular \\
\cline { 2 - 3 } & $\begin{array}{l}\text { Distancia a pozos } \\
\text { absorbentes }\end{array}$ & 3 metros \\
\end{tabular}

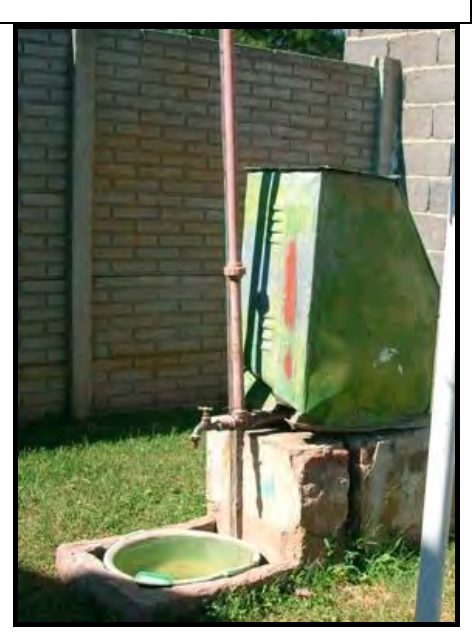

Figura 84. Perforación $\mathrm{N}^{\circ} 6$

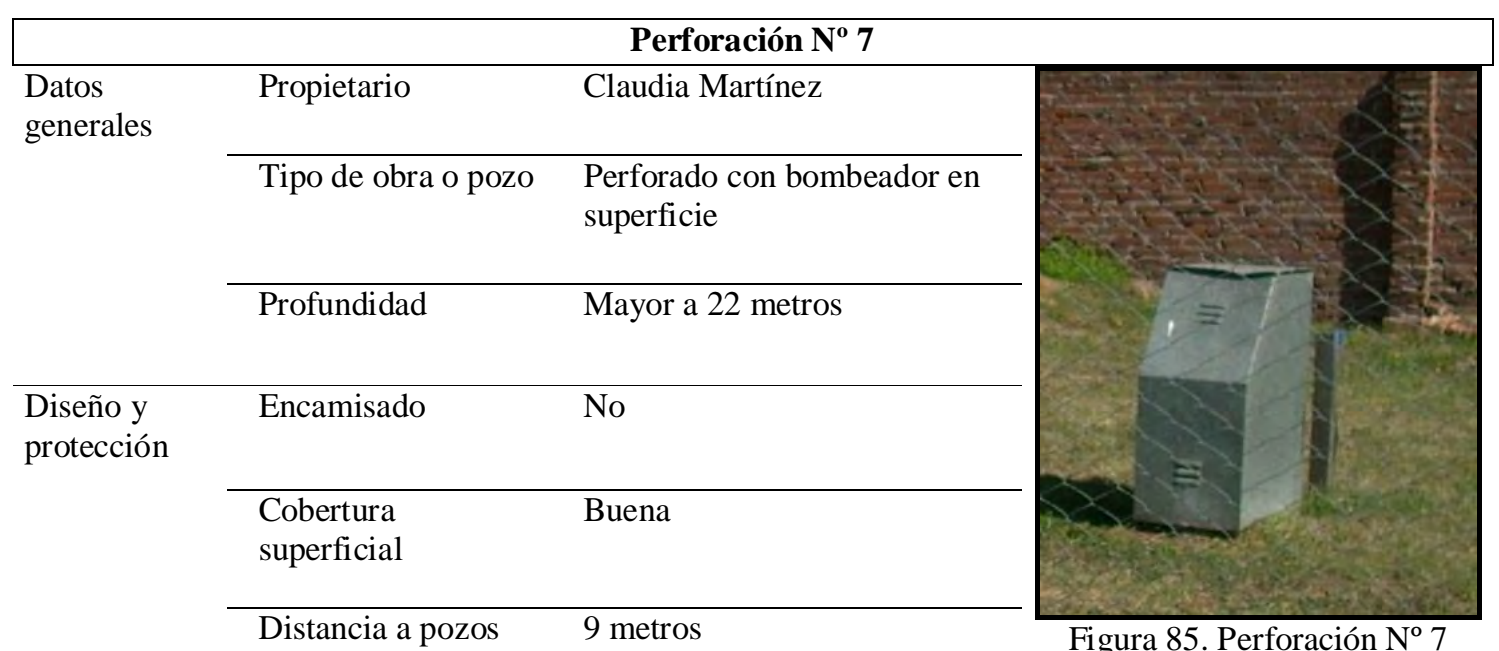

absorbentes 


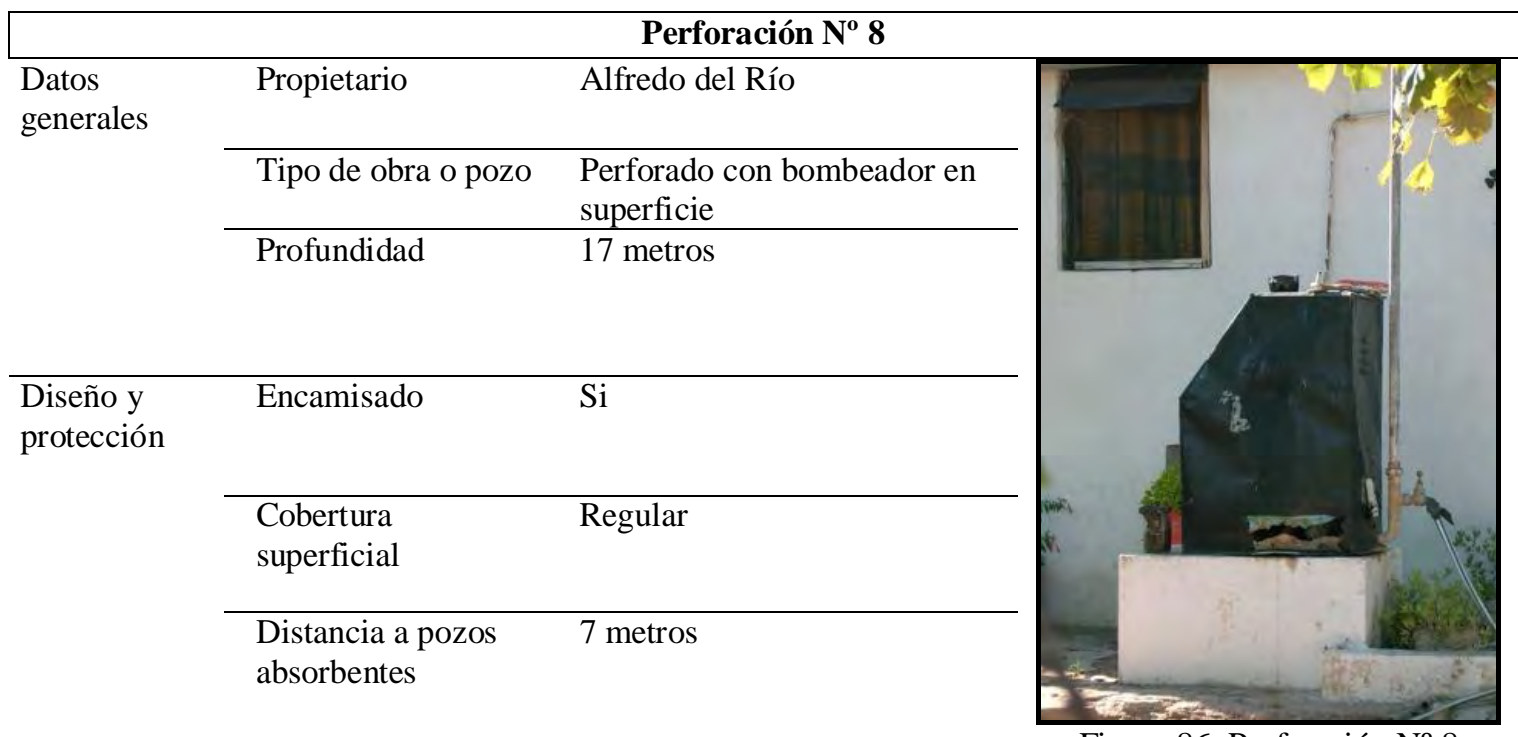

Figura 86. Perforación $\mathrm{N}^{\circ} 8$

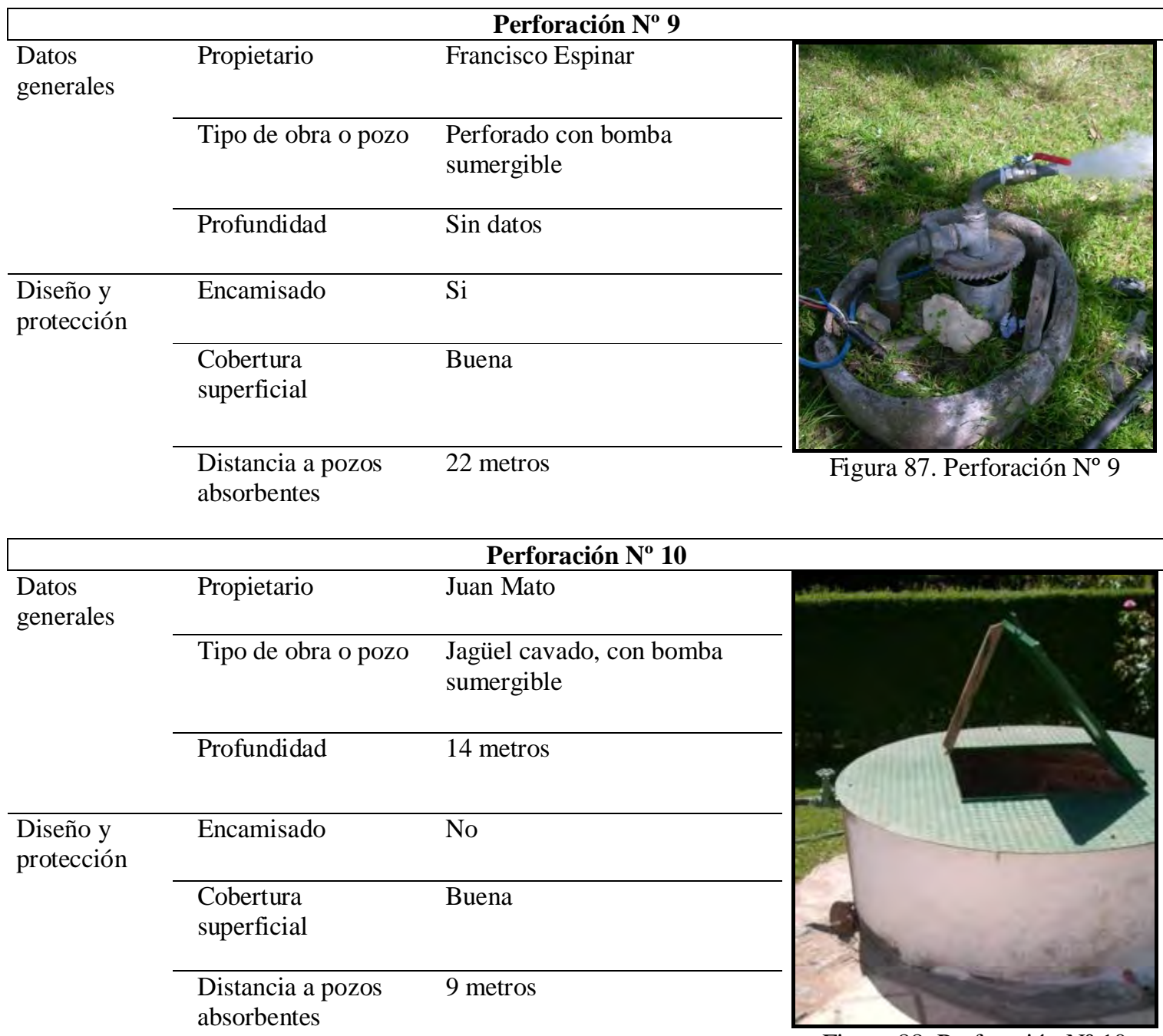

Figura 88. Perforación $\mathrm{N}^{\mathrm{o}} 10$ 


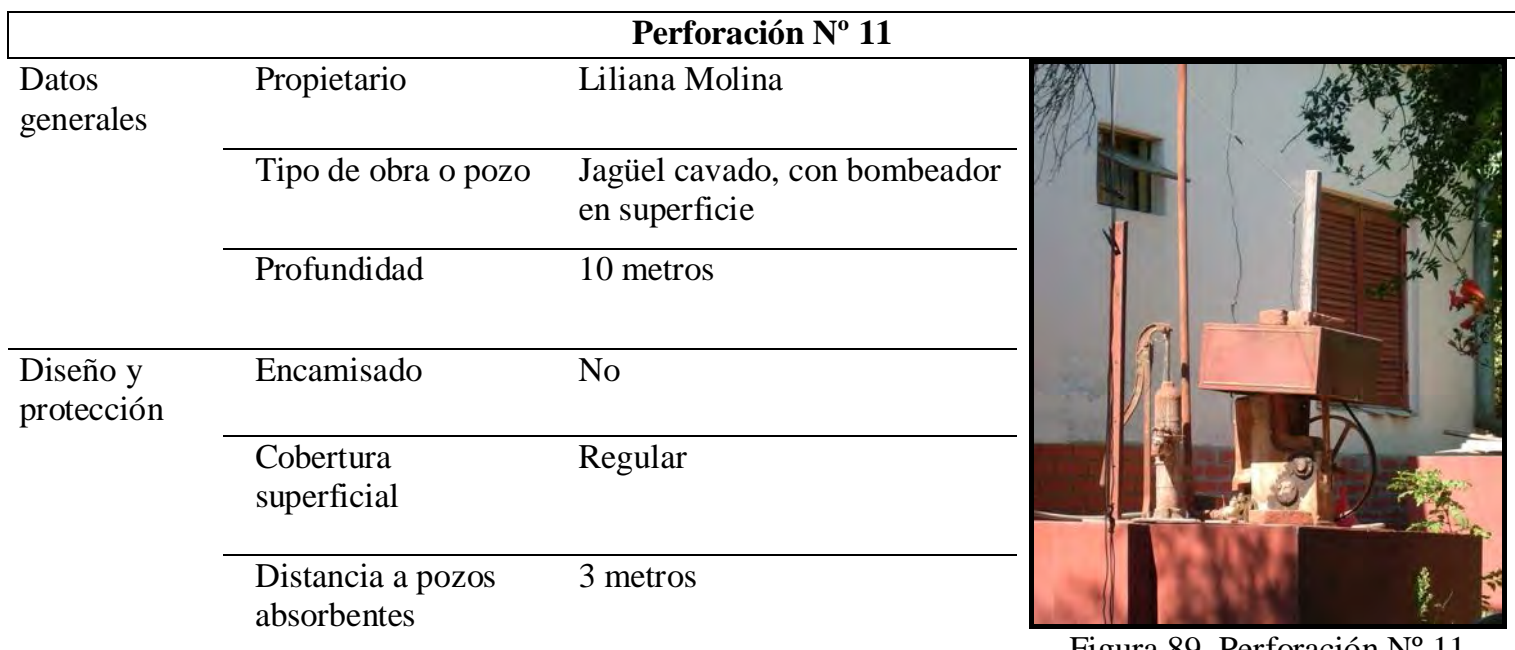

Figura 89. Perforación $\mathrm{N}^{\circ} 11$

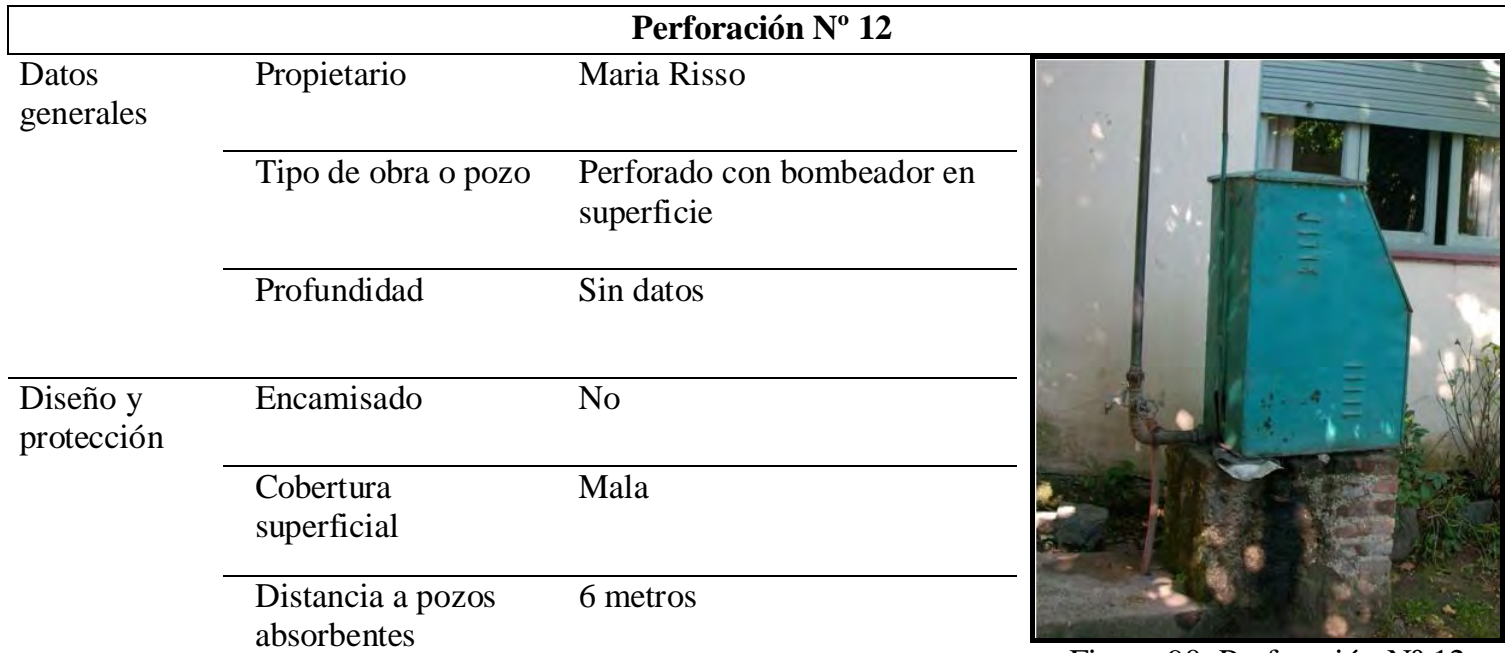

Figura 90. Perforación $\mathrm{N}^{\circ} 12$

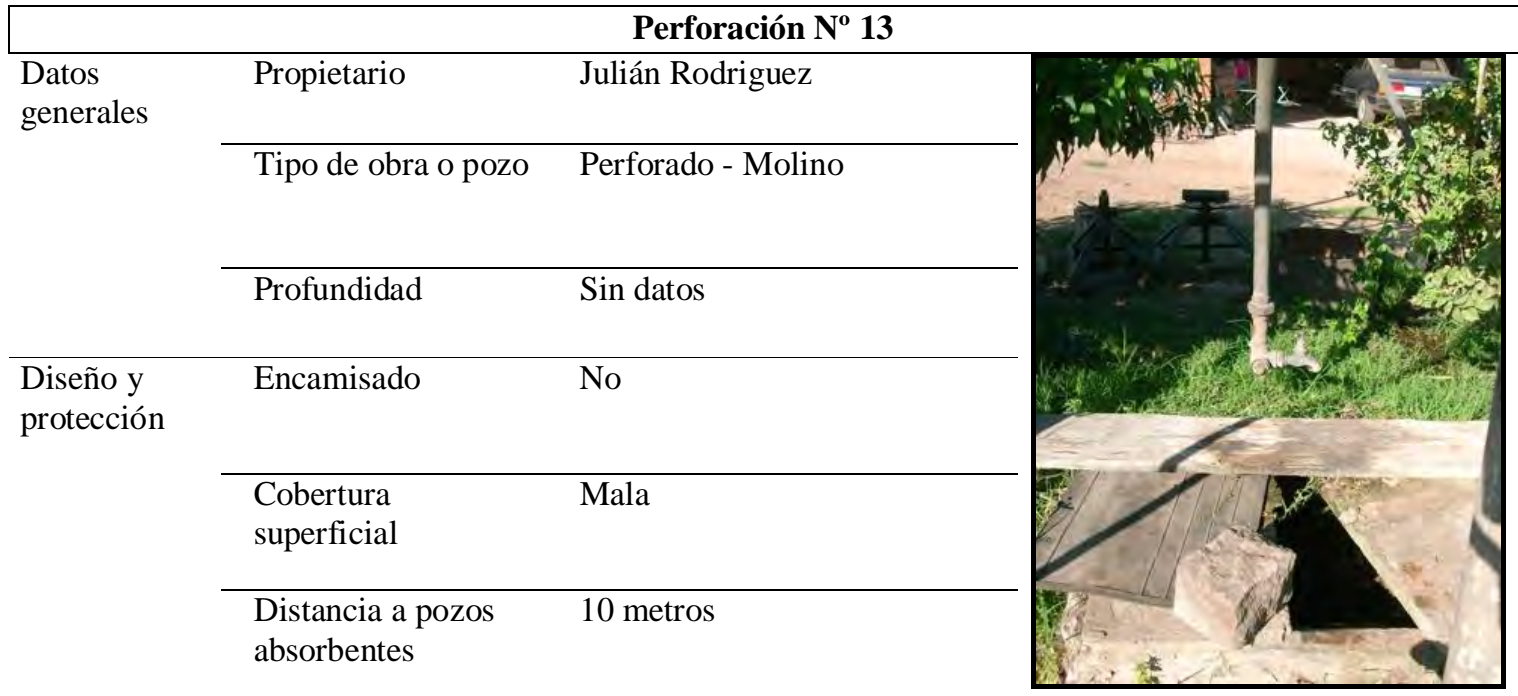

Figura 91. Perforación $\mathrm{N}^{\mathrm{o}} 13$ 


\begin{tabular}{|c|c|c|c|}
\hline \multicolumn{4}{|c|}{ Perforación No 14} \\
\hline \multirow{3}{*}{$\begin{array}{l}\text { Datos } \\
\text { generales }\end{array}$} & Propietario & Pedro C. Ridao & \\
\hline & Tipo de obra o pozo & $\begin{array}{l}\text { Perforado con bombeador en } \\
\text { superficie }\end{array}$ & \\
\hline & Profundidad & Sin datos & [9 \\
\hline \multirow{3}{*}{$\begin{array}{l}\text { Diseño y } \\
\text { protección }\end{array}$} & Encamisado & No & \\
\hline & $\begin{array}{l}\text { Cobertura } \\
\text { superficial }\end{array}$ & Mala & \\
\hline & $\begin{array}{l}\text { Distancia a pozos } \\
\text { absorbentes }\end{array}$ & 4 metros & $f$ \\
\hline
\end{tabular}

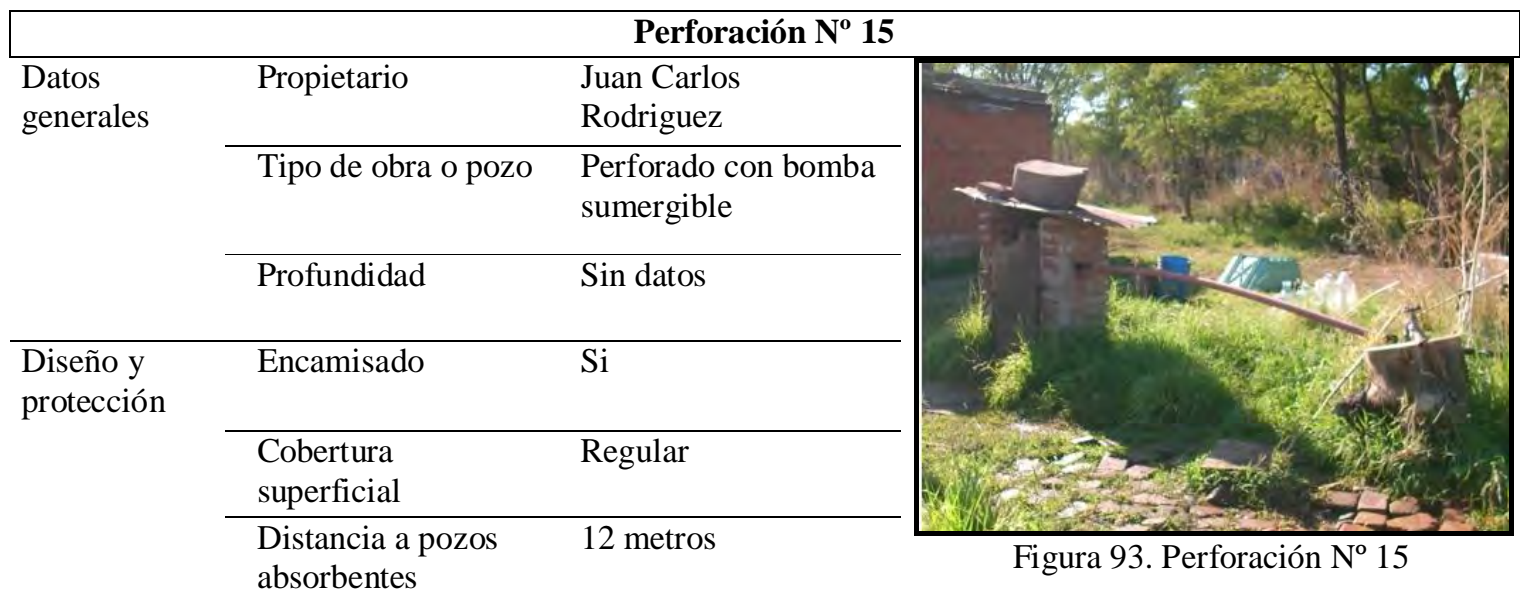

\begin{tabular}{|c|c|c|}
\hline & & Perforación $\mathrm{N}^{\circ} 16$ \\
\hline \multirow{3}{*}{$\begin{array}{l}\text { Datos } \\
\text { generales }\end{array}$} & Propietario & Jardín $\mathrm{N}^{\circ} 915$ \\
\hline & Tipo de obra o pozo & $\begin{array}{l}\text { Perforado con bomba } \\
\text { sumergible }\end{array}$ \\
\hline & Profundidad & Sin datos \\
\hline \multirow{2}{*}{$\begin{array}{l}\text { Diseño y } \\
\text { protección }\end{array}$} & Encamisado & $\mathrm{Si}$ \\
\hline & $\begin{array}{l}\text { Cobertura } \\
\text { superficial }\end{array}$ & Muy buena \\
\hline
\end{tabular}

Distancia a pozos 16 metros
absorbentes

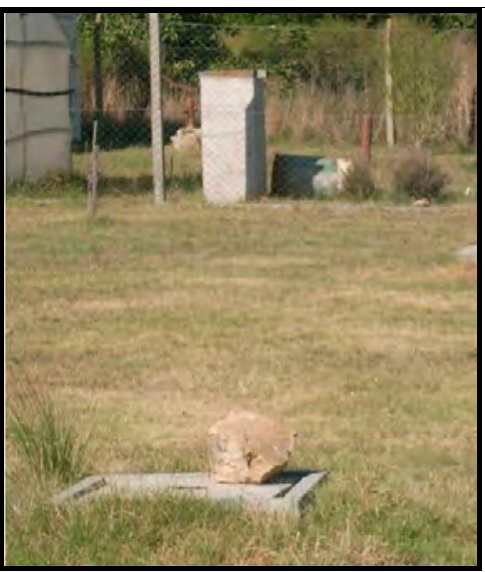

Figura 94. Perforación $\mathrm{N}^{\circ} 16$ 


\begin{tabular}{|c|c|c|c|}
\hline \multicolumn{4}{|c|}{ Perforación $\mathbf{N}^{\circ} 17$} \\
\hline \multirow{3}{*}{$\begin{array}{l}\text { Datos } \\
\text { generales }\end{array}$} & Propietario & Escuela $\mathrm{N}^{\circ} 4$ & \\
\hline & Tipo de obra o pozo & $\begin{array}{l}\text { Perforado con bombeador en } \\
\text { superficie }\end{array}$ & \\
\hline & Profundidad & Sin datos & \\
\hline \multirow{3}{*}{$\begin{array}{l}\text { Diseño y } \\
\text { protección }\end{array}$} & Encamisado & No & \\
\hline & $\begin{array}{l}\text { Cobertura } \\
\text { superficial }\end{array}$ & Regular & \\
\hline & $\begin{array}{l}\text { Distancia a pozos } \\
\text { absorbentes }\end{array}$ & 18 metros & Figura 95. Perforación $\mathrm{N}^{\circ} 17$ \\
\hline \multicolumn{4}{|c|}{ Perforación $\mathrm{N}^{\circ} 18$} \\
\hline \multirow[t]{3}{*}{$\begin{array}{l}\text { Datos } \\
\text { generales }\end{array}$} & Propietario & $\begin{array}{l}\text { Centro Comunitario y Sala de } \\
\text { Atención Primaria a la Salud }\end{array}$ & \\
\hline & Tipo de obra o pozo & $\begin{array}{l}\text { Perforado con bombeador en } \\
\text { superficie }\end{array}$ & \\
\hline & Profundidad & Sin datos & \\
\hline \multirow{3}{*}{$\begin{array}{l}\text { Diseño y } \\
\text { protección }\end{array}$} & Encamisado & No & \\
\hline & $\begin{array}{l}\text { Cobertura } \\
\text { superficial }\end{array}$ & Regular & \\
\hline & $\begin{array}{l}\text { Distancia a pozos } \\
\text { absorbentes }\end{array}$ & 8 metros & Figura 96. Perforación \\
\hline
\end{tabular}

\subsubsection{Fuentes de contaminación del agua subterránea}

En la zona del Barrio Cerro Los Leones el principal riesgo de contaminación de las aguas subterráneas lo constituye el vertido de los efluentes domiciliarios en pozos absorbentes, aunque se han registrado otras actividades que pueden afectar el recurso.

Se observaron basurales espontáneos, tanto dentro como en la periferia del barrio, a pesar de la recolección municipal de residuos realizada dos veces por semana. Uno de ellos se encuentra ubicado en una cava, a sólo pocos metros de las viviendas, como lo muestra la Figura 97. Se disponen en ella diferentes materiales como arenas de fundición, cubiertas, aserrín, restos vegetales provenientes de podas, residuos domiciliarios, escombros de construcción y otros materiales como chapas, maderas. Según algunos informantes del barrio, el vertido de residuos comenzó por un pedido vecinal avalado mediante autorización municipal con el objetivo de rellenar la excavación. 
Además de constituir un foco de contaminación para el agua subterránea, ocasiona problemas a la población en forma directa, debido a la presencia de olores, la dispersión de material particulado y de residuos por el viento, y el peligro de accidentes, sobre todo en niños. Durante las sucesivas observaciones del lugar de estudio, se verificó la presencia de niños y adultos buscando objetos entre los residuos. Una vez detectados estos problemas por parte de los vecinos, ellos iniciaron reclamos a las entidades correspondientes para frenar la disposición de cualquier tipo de residuos, pero aún no han obtenido respuesta.

Por otro lado, en la periferia SO del barrio se ha detectado un sitio de disposición final de residuos recolectados por empresas de transporte de contenedores. Por lo observado en forma directa, se disponen arenas de moldeo y escombros, entre otros, que son utilizados para el relleno de un sector deprimido.

Se ha evidenciado dentro de la zona habitada del barrio, la presencia de criaderos de animales, principalmente cerdos, que puede generar un aporte de materia orgánica importarte sobre el sistema hídrico. En algunos casos, se ubican muy próximos a las perforaciones de captación de agua para consumo humano, con la consecuente posibilidad de contaminación.

Otra actividad desarrollada en los alrededores del barrio, la constituye los más de 10 hornos ladrilleros, uno de los cuales es presentado en la Figura 98. Éstos tienen efectos principalmente sobre el suelo, al ser responsables de su decapitado. Se suma la emisión de humo a partir del horneado, lo cual afecta a los vecinos cercanos.



Figura 97. Basural espontáneo en el Barrio.

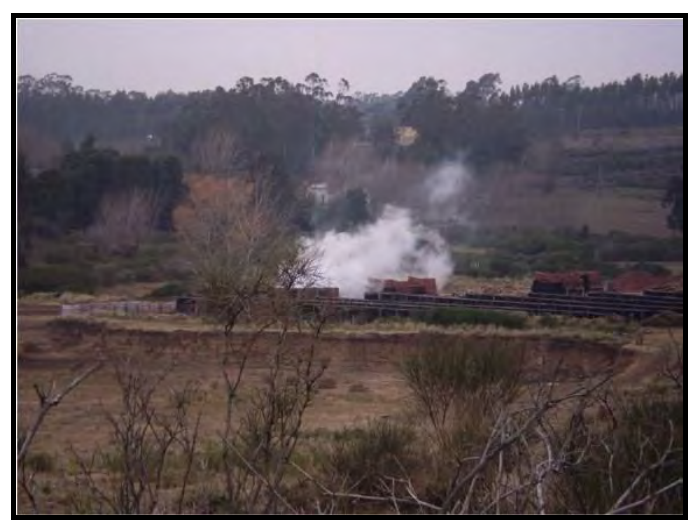

Figura 98. Horno ladrillero y cava de extracción de suelo. 


\section{PAUTAS DE GESTIÓN SUSTENTABLE}

\subsection{Abordaje sistémico de la problemática local}

A lo largo de la presente investigación se reconoció y caracterizó la problemática ambiental vinculada al recurso hídrico subterráneo en el Barrio Cerro Los Leones. A partir de allí, se analizaron los subsistemas natural y social, a través de diversas metodologías provenientes de las ciencias naturales y sociales. De esa manera, se logró el diagnóstico detallado y completo del sistema. En este apartado, y partiendo de la concepción del ambiente como estructura compleja (García, 1994), corresponde la integración de ambos subsistemas como base para la generación de pautas de gestión ambiental, tendientes a la sustentabilidad del recurso hídrico.

El diagnóstico del subsistema físico-natural permitió conocer las características y funcionamiento del sistema hídrico. Se detectó la clara influencia de las actividades antrópicas sobre el mismo, en tanto modifican la hidrodinámica subterránea y degradan la calidad del agua para consumo humano, demostrada mediante el análisis de parámetros físico-químicos y microbiológicos.

Con respecto al subsistema social, se caracterizaron los actores involucrados en la gestión local del agua y se analizaron los modos de explotación y uso de la misma. De ese modo, surgieron cuestiones relevantes como la falta de información acerca de la problemática ambiental y los modos para prevenirla o corregirla; las falencias en cuanto al diseño, construcción y protección sanitaria de las perforaciones de captación y los pozos absorbentes; la falta de planificación y control sobre las acciones antrópicas que afectan al recurso, entre otros factores que influyen tanto sobre el sistema hídrico como la calidad de vida.

Este abordaje integral permitió visualizar que a partir de las condiciones de explotación y uso del agua por parte de la población, surgen alteraciones en el funcionamiento del sistema hidrológico. Uno de los principales factores afectados fue la calidad del agua subterránea, en este caso debido principalmente a la infiltración de los efluentes domiciliarios, generando la contaminación de un recurso vital para los habitantes del lugar.

El uso doméstico del agua que no cumple las características de aptitud para el consumo humano, como en este caso, puede afectar la salud, e impactar sobre la calidad de vida de la población.

Ante este panorama, se plantearon tres tipos de pautas de gestión ambiental, que pretenden colaborar en la búsqueda de la sustentabilidad. La primera de ellas constituida 
por las tareas de educación ambiental y transferencia de resultados hacia los actores involucrados. La segunda incluye la confección de indicadores básicos de sustentabilidad ambiental. Por último, se establece una serie de estrategias de gestión ante la problemática analizada.

\subsection{Tareas de educación ambiental y transferencia}

La educación ambiental es una herramienta imprescindible en el camino hacia la sustentabilidad. Requiere la participación conjunta de gestores ambientales y actores involucrados en cada problemática, desde su diagnóstico hasta la confección de pautas de manejo.

En ese marco, la Licenciada Corina Iris Rodriguez generó y puso en práctica estrategias de educación ambiental y transferencia en el área de estudio, con el propósito de promover un cambio de hábitos y actitudes cotidianas. Estas actividades se desarrollaron a lo largo de todo el período de investigación, contándose con el acompañamiento por parte de la población.

El contacto directo con los habitantes en sus viviendas a lo largo de los censos y muestreos y en los talleres, permitió conocer la situación de cada familia con relación al agua y generar alternativas ante los problemas detectados. Además, el acercamiento con la comunidad posibilitó el conocimiento de la percepción social del ambiente y la corrección de situaciones problemáticas.

Por un lado, y durante el transcurso de las tareas de investigación, se realizó una devolución de los resultados de los análisis físico-químicos y bacteriológicos a los habitantes del barrio Cerro Los Leones. Para ello se realizaron dos tipos de informes individuales donde se indicaron los parámetros evaluados, los resultados obtenidos, y los valores permisibles regulados mediante la legislación nacional, establecidos en el Código Alimentario Argentino.

En el Anexo IV se presenta el modelo de informe de análisis físico químico entregado a los habitantes, mientras que en el Anexo V se muestra el correspondiente a los resultados microbiológicos. En los mismos se incluyó, en forma clara y concisa y según cada caso particular, una explicación acerca de las medidas que se pueden tomar para prevenir o corregir los problemas presentes. Entre éstas se hizo referencia a la necesidad de proteger a las perforaciones de la contaminación superficial, realizar en forma periódica y correcta la desinfección de tanques y cañerías, así como de pozos, para lo cual se indicó una metodología que puede ser llevada a cabo sencillamente por cualquier individuo. 
Los informes fueron entregados, en forma escrita, acompañados de una explicación oral por parte de la Licenciada Corina Rodriguez, quien hizo hincapié en los problemas detectados en cada vivienda, principalmente referidos a la presencia de concentraciones de nitratos superiores a los niveles permisibles, así como a la existencia de microorganismos patógenos en agua, tales como mesófilos, coliformes totales y fecales, cuyo número superó los niveles fijados en la legislación argentina. Los resultados generales de los análisis también fueron informados a la Trabajadora Social a cargo del Centro Comunitario barrial, así como a la Médica y Enfermero de la Sala de Atención Primaria a la Salud.

Por otro lado, y de acuerdo al diagnóstico previo, se plantearon estrategias para el ámbito educativo formal y no formal dentro del Barrio Cerro Los Leones, incluyendo talleres en los establecimientos locales y encuentros con la comunidad, a cargo de la autora de la presente tesis. En todos los casos, y tomando como eje temático al agua, se partió de conceptos generales hasta lograr la comprensión de la problemática ambiental. Los ejes centrales fueron: importancia y usos del agua, ciclo hidrológico y sistema hídrico subterráneo, problemática ambiental local, calidad del agua, potabilidad, efectos sobre la salud y alternativas de gestión.

En el ámbito formal, se incluyeron las Escuelas Primaria $\mathrm{N}^{\circ} 4$ y Secundaria $\mathrm{N}^{\circ} 15$ (que funcionan en el mismo edificio) y el Jardín de Infantes $\mathrm{N}^{\circ} 915$, ilustrados en las Figuras 99 y 100. En todos los casos se incentivó la participación de los chicos, tratando de indagar sobre sus conocimientos previos y sus vivencias. Los talleres intentaron lograr la comprensión del sistema ambiental y de la problemática del barrio, sin generar en ellos un estado de alarma, e intentando que se conviertan en transmisores de la información hacia sus allegados.

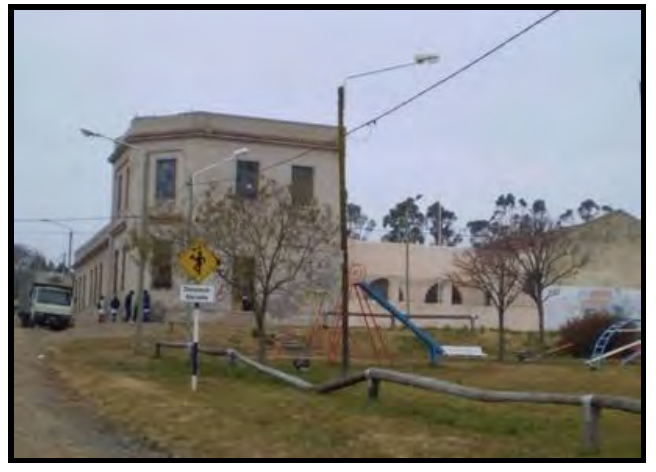

Figura 99. Escuelas Primaria $\mathrm{N}^{\circ} 4$ y Secundaria $\mathrm{N}^{\mathrm{o}} 15$.

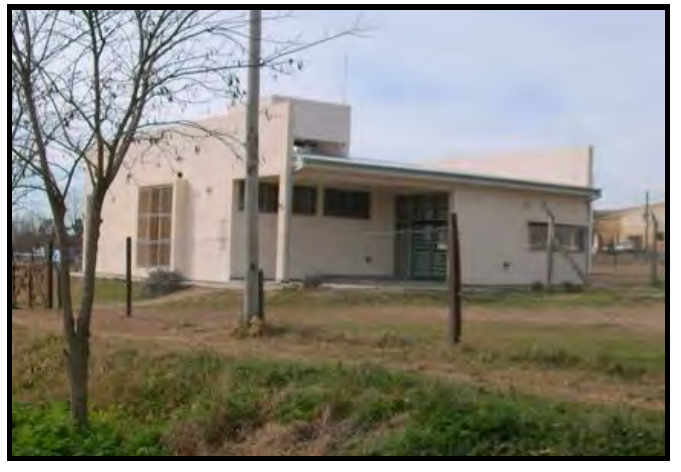

Figura 100. Jardín de Infantes $N^{\circ} 915$.

En el caso de la Escuela Secundaria, se realizó un encuentro con los alumnos de $7^{\circ}$, $8^{\circ}$ y $9^{\circ}$ año (tercer ciclo), con un total de aproximadamente 60 alumnos. El mismo se presenta en la Figura 101. En la Escuela Primaria, se concretaron dos encuentros con los 
alumnos de $1^{\circ}, 2^{\circ}$ y $3^{\circ}$ año (primer ciclo), y uno con los alumnos de $4^{\circ}, 5^{\circ}$ y $6^{\circ}$ año (segundo ciclo). Ambos casos de muestran en las Figuras 102 y 103.

Todos los talleres escolares se ocuparon de la comprensión de los siguientes temas: Conceptos de ambiente y problemática ambiental. Ejemplos de la ciudad de Tandil, así como del barrio en particular. Importancia del agua para la vida y usos del agua. Funcionamiento del ciclo hidrológico. Conceptos básicos de acuífero y agua subterránea. Contaminación hídrica: fuentes. Efluentes domiciliarios. Calidad del agua para consumo humano. Posibles efectos sobre la salud de la población. Medidas preventivas o correctivas ante la problemática local.

Para continuar con esta tarea de educación ambiental, se organizó un taller para los alumnos del Jardín de Infantes $\mathrm{N}^{\circ}$ 912, el cual se observa en la Figura 104. En esta oportunidad se trabajó con niños de 3, 4 y 5 años, a partir del uso de imágenes que funcionaron como disparadores. Éstas mostraban cuestiones relacionadas con el agua y su uso por parte de los habitantes. A partir de allí, los temas tratados se basaron en sus usos cotidianos en el hogar, su importancia para las personas y la vida en general. Se concluyó enfatizando en las medidas o acciones que los niños y sus familias pueden tomar con el objetivo de prevenir o corregir aspectos relacionados al uso doméstico del agua.

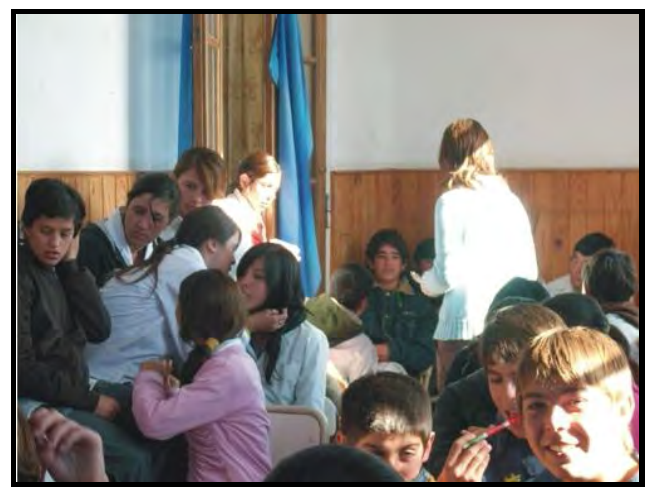

Figura 101. Taller con alumnos de $3^{\text {er }}$ ciclo.

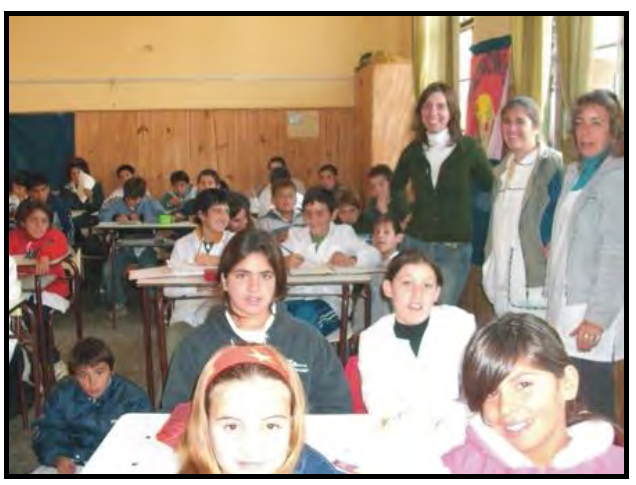

Figura 103. Taller con alumnos de $2^{\text {do }}$ ciclo.

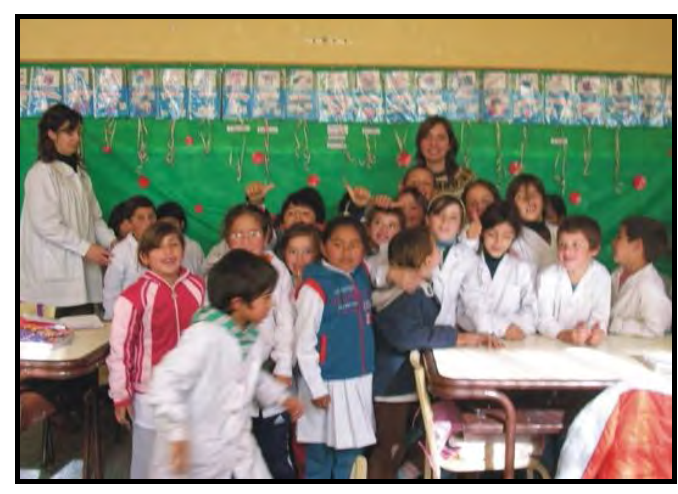

Figura 102. Taller con alumnos de $1^{\text {er }}$ ciclo.

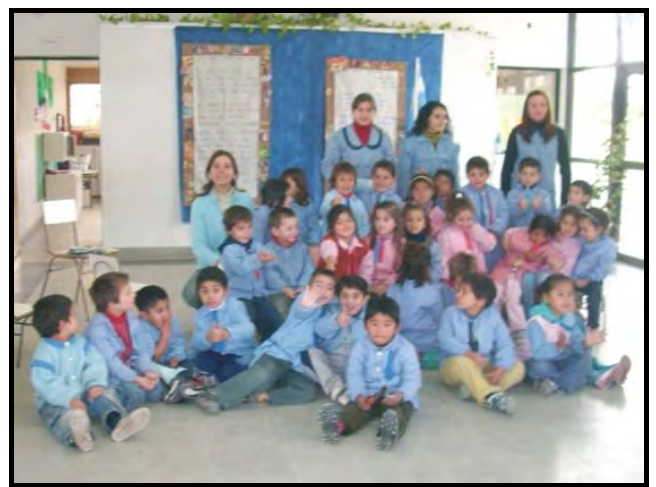

Figura 104. Taller con alumnos del Jardín de Infantes. 
En ámbitos no formales, se trabajó con los habitantes durante los censos y muestreos y en la devolución de resultados. Posteriormente, se intentó el acercamiento con la comunidad en general, para lo cual se convocó a un taller, realizado en el Jardín de Infantes del Barrio. Previamente se efectuó la difusión a través de cartelería en diferentes lugares de referencia dentro del barrio (Escuela, Centro Comunitario, almacenes, Club, Biblioteca).

Lamentablemente, la convocatoria fue escasa, algunos de los adultos presentes se ilustran en la Figura 105. De igual modo se llevó adelante la charla-taller, donde se debatió sobre la problemática ambiental del barrio Cerro Los Leones, en relación al agua subterránea, específicamente incluyó:

- Comprensión del ciclo hidrológico con especial atención al sistema subterráneo.

- Concepto de acuífero y modo de explotación del recurso hídrico en el barrio.

- Fuentes de contaminación del agua, haciendo hincapié en los efluentes domiciliarios, que constituyen el principal foco contaminante en la zona de estudio.

- Censo de perforaciones: medición de los niveles freáticos e interpretación general del escurrimiento subterráneo.

- Calidad del agua para consumo humano. Posibles efectos sobre la salud de la población que ingiere agua no apta para bebida.

- Muestreos periódicos y análisis de agua: parámetros analizados y resultados obtenidos.

- Estrategias de gestión ambiental ante la problemática local.

Del diálogo y la participación surgieron ideas compartidas tendientes a mejorar la situación. Considerando las características hidrogeológicas locales y la situación sanitaria evaluada, se generaron alternativas para mejorar las condiciones de explotación y uso del agua, tales como: desinfección de tanques, pozos y cañerías, protección sanitaria de las perforaciones y distanciamiento entre éstas y los pozos absorbentes. También se consideró el abastecimiento de agua apta para consumo de los grupos poblacionales más susceptibles. Se destacó la importancia de la ausencia de animales y residuos cercanos a las perforaciones. Se tuvieron en cuenta cuestiones vinculadas a la higiene personal y de los alimentos, así como las alternativas de disposición y tratamiento de efluentes. 


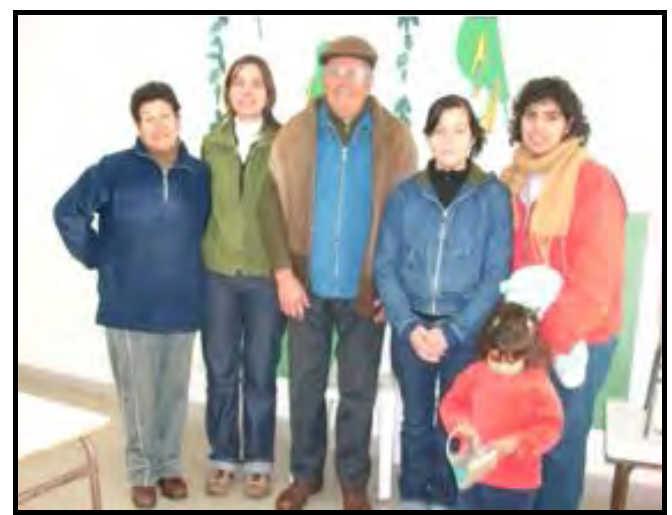

Figura 105. Adultos presentes en la charla-taller.

A lo largo del trayecto recorrido durante la investigación, quedó demostrada la importancia de las tareas de educación, al observar que los habitantes adoptaron algunas de estas medidas.

Una vez avanzadas las actividades de educación ambiental y transferencia de los resultados parciales del trabajo, se constató en algunos hogares la puesta en práctica de tareas, a partir de los consejos brindados en las sucesivas visitas. En la perforación $\mathrm{N}^{\mathbf{o}} 4$, de María Luján Ramil, tras detectar problemas en la perforación, ya que bombeaba gran cantidad de sedimentos, los propietarios modificaron los filtros. Según sus comentarios, el cambio trajo buenos resultados, evitando la remoción de sedimentos. Por su parte, en la perforación $\mathrm{N}^{\mathrm{o}}$ 10, el propietario Juan Mato realizó la desinfección de la misma, así como del tanque y las cañerías siguiendo las recomendaciones brindadas. Otro ejemplo corresponde a la perforación $\mathrm{N}^{\mathbf{0}}$ 2, de Karina Ravena, que llevó a cabo idénticas tareas siguiendo los consejos indicados en el informe.

Posteriormente, se repitieron los análisis bacteriológicos en las viviendas donde se aplicaron medidas de desinfección, encontrando que los valores detectados de algunas bacterias disminuyeron, aunque en dos de ellas su presencia continuaba descalificando su aptitud para consumo.

Lo mismo se repitió en otras viviendas, de los Sres. Alfredo del Río, Marcela Olavaria y Alfredo Palacios. El objetivo fue controlar los resultados anteriores, ya que estas personas no realizaron ningún proceso de desinfección ni cambios en el sistema de protección sanitaria de la perforación. En los dos primeros casos, continuó la presencia de bacterias que vuelven no apta al agua para consumo. Mientras que en la perforación del señor Alfredo Palacios se siguió observando buena calidad. 


\subsection{Indicadores básicos de sustentabilidad}

En esta época de grandes cambios demográficos, tecnológicos y económicos, el paradigma del desarrollo sustentable debe orientarse no sólo a preservar la dimensión ecológica del desarrollo, sino también a aumentar la capacidad social, ecológica y económica de hacer frente a esos cambios (Gallopín, 2003).

El concepto de sustentabilidad no se refiere al sostenimiento o perpetuación de un sistema en el tiempo, sino al proceso de cambio temporal que dicho sistema atraviesa. Por tal motivo, se vuelve relevante el establecimiento de indicadores de sustentabilidad que permitan la caracterización, evaluación y seguimiento de una problemática ambiental, como la presentada en esta tesis. Los indicadores necesarios deben ser claros y sencillos, pasibles de ser utilizados por los tomadores de decisión.

Según el International Council for Local Environmental Initiatives (ICLEI, 1996), los indicadores de sustentabilidad son "instrumentos para medir las condiciones aceptadas por una sociedad como criterios válidos para la evaluación del progreso hacia la sustentabilidad". Un buen indicador alerta sobre el problema y revela la necesidad de solucionarlo.

Tal como se detalló en el ítem Metodología, se utilizó el Modelo de indicadores de Presión-Estado-Respuesta (PER) de la Organización para la Cooperación y el Desarrollo Económico (OCDE, 1993), que constituye uno de los principales antecedentes en la temática.

Los indicadores de Presión describen las intervenciones directas e indirectas que las actividades humanas ejercen sobre el medio físico-natural, en este caso el agua, resultantes de la interrelación sociedad-naturaleza. Los indicadores de Estado incluyen todo lo relacionado con la evaluación cuantitativa y cualitativa del recurso hídrico, tanto sus características hidrodinámicas, hidroquímicas y microbiológicas. Los referidos a la Respuesta, se ocupan de las medidas desde el orden socio-político para evitar, corregir, mitigar o cambiar tendencias en el comportamiento de los individuos o aquellas políticas que degradan el recurso.

El modelo de indicadores de PER es un modo integral de evaluar el ambiente por las presiones socioeconómicas sobre los recursos naturales y sus impactos. Resalta la situación actual del ambiente e integra en su análisis el grado de acciones en que los sectores económicos y sociales responden a las presiones y tendencias sobre la calidad y degradación del ambiente. 
En esta investigación los indicadores PER permitirán evaluar y monitorear la intensidad de la intervención humana sobre el recurso hídrico subterráneo en el área de estudio; las características y calidad ambiental resultantes de los modos de explotación y uso del mismo, y las respuestas sobre esa calidad y disponibilidad ambiental.

El modelo PER tiene la ventaja de ser uno de los sistemas de indicadores más fáciles de entender y utilizar, que destaca las relaciones causa-efecto, y ayuda a los tomadores de decisiones y a los actores sociales a conocer las interrelaciones que caracterizan al ambiente (OECD, 1993).

En esta instancia, se elaboraron algunos indicadores básicos, en función de la disponibilidad de información, cuestión fundamental para su establecimiento. Los mismos sientan una base para la generación de datos necesarios en el futuro, que permitan su cuantificación, seguimiento y evolución, tarea que reviste interés para su desarrollo en otros trabajos de investigación. Asimismo, se deja expresada la necesidad de continuar trabajando en un sistema integral de indicadores, donde se vinculen variables sociales y naturales en un mismo índice, y que permitan conocer el grado de impacto ambiental producido.

En la Tabla 20 se establecen los indicadores elaborados, según el modelo PER y teniendo en cuenta algunas de las variables consideradas por Guerrero et al. (2007), donde se describe cada indicador, la variable a medir y la frecuencia de monitoreo.

De ese modo, los indicadores de presión dan cuenta de las intervenciones humanas sobre el recurso hídrico subterráneo. Un ejemplo es la densidad de pozos absorbentes, de forma tal que un incremento en ese indicador posibilita una mayor afectación del recurso. Otra variable de interés es la distancia entre las perforaciones de captación y los pozos absorbentes, ya que a medida que la misma es menor, facilita el transporte de efluente hacia el bombeo. Igual importancia tienen las características constructivas y el estado de mantenimiento de las perforaciones, ya que como se detalla en el ítem 5.4, tienen relación con la preservación de la calidad del agua subterránea. Por su parte, la profundidad del nivel freático puede influir sobre el transporte de los contaminantes de distinto origen hacia las perforaciones de bombeo.

Para evaluar el impacto resultante de dichas presiones, se utilizan los indicadores de estado. En este caso, el contenido de sales disueltas, las concentraciones de nitratos y los parámetros microbiológicos, se encuentran directamente relacionados a la contaminación por el vertido de efluentes domiciliarios.

Los impactos o estados generados a partir de las presiones antrópicas, pueden ser mitigados o corregidos a través de diferentes respuestas por parte de los actores sociales 
involucrados en la gestión del recurso. Alguna de esas respuestas pueden ser campañas de educación ambiental por parte del gobierno local, instituciones educativas u otras organizaciones vinculadas. Otro ejemplo lo constituye la puesta en práctica de estrategias de gestión por los habitantes del barrio, tales como la desinfección, la mejora en el estado de las perforaciones y los pozos absorbentes. Asimismo, es importante evaluar y monitorear la generación y concreción de medidas de planificación y control sobre los recursos hídricos a escala regional. Esto permitirá modificar y corregir las acciones, tendiendo a la prevención y disminución de los impactos ambientales, en el marco de una gestión integral del agua.

Tabla 20. Indicadores PER para el área de estudio.

\begin{tabular}{|c|c|c|c|c|}
\hline Tipo & Indicador & Descripción & Variable & Frecuencia \\
\hline \multirow{4}{*}{ 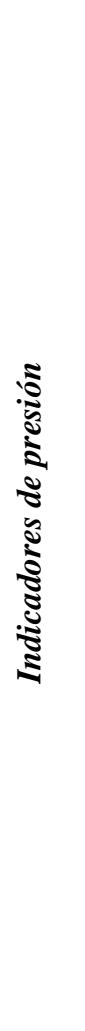 } & $\begin{array}{l}\text { Densidad de } \\
\text { pozos } \\
\text { absorbentes }\end{array}$ & $\begin{array}{l}\text { La cantidad y distribución de los pozos } \\
\text { absorbentes en el área puede brindar } \\
\text { información sobre los principales focos } \\
\text { contaminantes del recurso subterráneo. }\end{array}$ & $\begin{array}{l}\mathrm{N}^{\mathrm{o}} \text { pozos } \\
\text { absorbentes/ } \\
\text { ha }\end{array}$ & Anual \\
\hline & $\begin{array}{l}\text { Distancia entre } \\
\text { pozos } \\
\text { absorbentes y } \\
\text { perforaciones } \\
\text { de bombeo }\end{array}$ & $\begin{array}{l}\text { El distanciamiento pone en evidencia la } \\
\text { facilidad de transporte de las sustancias } \\
\text { contenidas en los efluentes, y su } \\
\text { contaminación sobre el sistema subterráneo } \\
\text { utilizado como fuente para consumo } \\
\text { humano. }\end{array}$ & Metros & Anual \\
\hline & $\begin{array}{l}\text { Diseño y } \\
\text { protección } \\
\text { sanitaria de las } \\
\text { perforaciones }\end{array}$ & $\begin{array}{l}\text { Las características de las perforaciones, } \\
\text { tanto su construcción como su cobertura } \\
\text { superficial y su estado, son relevantes para } \\
\text { conocer su facilidad de contaminación desde } \\
\text { la superficie así como en profundidad. }\end{array}$ & $\begin{array}{l}\text { Estado de la } \\
\text { perforación } \\
\text { (variable } \\
\text { cualitativa) }\end{array}$ & Anual \\
\hline & $\begin{array}{l}\text { Profundidad } \\
\text { del nivel } \\
\text { freático }\end{array}$ & $\begin{array}{l}\text { La profundidad del nivel freático y sus } \\
\text { variaciones pueden influir sobre el vertido } \\
\text { de efluentes domiciliarios y la disposición } \\
\text { de residuos sólidos, facilitando la llegada de } \\
\text { los contaminantes al acuífero. }\end{array}$ & Metros & Trimestral \\
\hline
\end{tabular}




\begin{tabular}{|c|c|c|c|c|}
\hline Tipo & Indicador & Descripción & Variable & Frecuencia \\
\hline \multirow{3}{*}{ 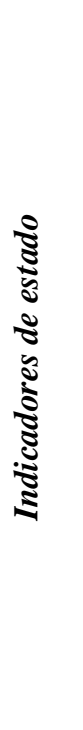 } & $\begin{array}{l}\text { Conductividad } \\
\text { eléctrica en } \\
\text { agua de bebida }\end{array}$ & $\begin{array}{l}\text { La conductividad eléctrica expresa } \\
\text { indirectamente la salinidad del agua, la que } \\
\text { da una idea general de la calidad } \\
\text { fisicoquímica de la misma y su posible } \\
\text { contaminación. }\end{array}$ & $\mathrm{uS} / \mathrm{cm}$ & Trimestral \\
\hline & $\begin{array}{l}\text { Concentracion } \\
\text { es de nitratos } \\
\text { en agua de } \\
\text { bebida }\end{array}$ & $\begin{array}{l}\text { La presencia de el ión nitrato es indicador de } \\
\text { contaminación antrópica. La legislación } \\
\text { argentina establece un límite recomendable } \\
\text { de } 45 \mathrm{mg} \mathrm{NO}{ }^{-} \text {/litro. }\end{array}$ & $\mathrm{mg} \mathrm{NO}_{3}{ }^{-} / 1$ & Trimestral \\
\hline & $\begin{array}{l}\text { Aptitud } \\
\text { microbioló- } \\
\text { gica del agua } \\
\text { para consumo } \\
\text { humano }\end{array}$ & $\begin{array}{l}\text { El Código Alimentario Argentino estipula } \\
\text { los parámetros microbiológicos y sus niveles } \\
\text { permisibles para el agua de consumo } \\
\text { humano. Cuando uno de ellos no se cumple } \\
\text { el agua es no apta para tal uso. }\end{array}$ & $\begin{array}{l}\text { Parámetros } \\
\text { establecidos } \\
\text { en el CAA } \\
\text { (Tabla 14) }\end{array}$ & Trimestral \\
\hline \multirow{4}{*}{ 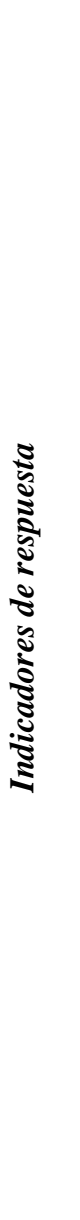 } & $\begin{array}{l}\text { Educación } \\
\text { ambiental }\end{array}$ & $\begin{array}{l}\text { Las campañas de educación ambiental y sus } \\
\text { alcances, expresan la gestión iniciada por el } \\
\text { gobierno local, instituciones públicas, u } \\
\text { otros organismos, tendiente a capacitar a la } \\
\text { población sobre el uso y preservación del } \\
\text { ambiente, en especial el recurso hídrico. }\end{array}$ & $\begin{array}{l}\mathrm{N}^{\mathrm{o}} \text { y tipo de } \\
\text { actividades/ } \\
\text { año }\end{array}$ & Anual \\
\hline & $\begin{array}{l}\text { Difusión y } \\
\text { publicaciones }\end{array}$ & $\begin{array}{l}\text { Incluye la publicación y difusión en medios } \\
\text { locales, tanto gráficos, como audiovisuales, } \\
\text { de temas relacionados a la provisión de agua } \\
\text { en el área de estudio, la calidad de la misma, } \\
\text { así como problemáticas similares en otros } \\
\text { sectores urbanos. }\end{array}$ & $\begin{array}{l}\mathrm{N}^{o} \text { y tipo de } \\
\text { publicacio- } \\
\text { nes/año }\end{array}$ & Anual \\
\hline & $\begin{array}{l}\text { Acciones de } \\
\text { los habitantes }\end{array}$ & $\begin{array}{l}\text { Adquisición de conocimientos y puesta en } \\
\text { práctica, por parte de los pobladores, de } \\
\text { medidas de protección ambiental y } \\
\text { saneamiento de las perforaciones, tendientes } \\
\text { a la mejora de las condiciones de } \\
\text { explotación y uso del agua. }\end{array}$ & $\begin{array}{l}\mathrm{N}^{\mathrm{o}} \text { y tipo de } \\
\text { acciones/ } \\
\text { año. }\end{array}$ & Anual \\
\hline & $\begin{array}{l}\text { Proyectos y } \\
\text { obras }\end{array}$ & $\begin{array}{l}\text { Planificación y puesta en práctica de } \\
\text { medidas preventivas y correctivas frente a la } \\
\text { problemática ambiental detectada. Pueden } \\
\text { provenir del gobierno local como de } \\
\text { instituciones vinculadas a la temática } \\
\text { hídrica. }\end{array}$ & $\begin{array}{l}\mathrm{N}^{\mathrm{o}} \text { y tipo de } \\
\text { proyectos y } \\
\text { obras/ año. }\end{array}$ & Anual \\
\hline
\end{tabular}




\subsection{Estrategias de gestión sustentable del recurso hídrico}

Una vez analizada exhaustivamente la problemática hídrica en el área de estudio, abordada desde los subsistemas natural y social, y llevado adelante el contacto con la población, se volvió necesaria la generación de estrategias de gestión sustentable del recurso hídrico, basadas en las actuales condiciones de uso del mismo.

Por tal motivo, se enunciaron diferentes medidas, tanto de tipo estructural como no estructural. Se consideraron estrategias de planificación, evaluación, control y seguimiento, encaradas por el gobierno municipal y provincial y otras instituciones; de educación ambiental, destinadas a la capacitación y concientización de la población para preservar y conservar el recurso hídrico así como mejorar su calidad de vida; y otras basadas en propuestas técnicas tendientes a solucionar algunos de los problemas detectados tanto en los sistemas de extracción de agua como en aquellos destinados a la disposición de efluentes domiciliarios.

Considerando que la ecohidrología propone la utilización de procesos ecológicos e hidrológicos para mejorar y mantener la integridad del ambiente frente a las alteraciones humanas, algunas de las medidas desarrolladas en este trabajo intentaron alinearse hacia ese objetivo, valorizando la capacidad propia de los ecosistemas para mitigar los impactos adversos.

Las medidas planteadas, enmarcadas en el enfoque de la Gestión Integrada de los Recursos Hídricos (GIRH), de carácter sustentable y sistémico, pretenden ser útiles para los tomadores de decisiones, permitiendo llevar a cabo elecciones racionales e informadas entre acciones alternativas ajustadas a la realidad local (GWP, 2000).

\subsubsection{Planificación y control de la explotación y uso del agua}

Para organizar y adecuar la explotación y uso del recurso hídrico subterráneo a escala local, se requieren estrategias de planificación y control en el ámbito regional que consideren todos los actores involucrados en la gestión del agua.

Una de las principales tareas consiste en la planificación territorial, destinada al ordenamiento de los usos del suelo en distintas áreas de una cuenca, permitiendo la preservación del recurso hídrico en las zonas de recarga, así como en zonas de explotación para consumo humano.

El abastecimiento de agua potable y el manejo adecuado de los efluentes domiciliarios deben ser objetivos primordiales. Deben elaborarse y presentarse proyectos de obras de saneamiento y buscarse el financiamiento para la construcción y 
funcionamiento de las mismas. Cabe comentar que en el año 2009 se difundió, a través de los medios locales (Diario El Eco de Tandil, 17/12/2008 y 29/04/2009), el proyecto de la obra de provisión de agua potable para el Barrio Cerro Los Leones. Sería importante que también se considere el tendido de red cloacal, permitiendo la colección y tratamiento de los efluentes domiciliarios, que posiblemente se incrementen una vez que la población reciba el abastecimiento de agua de red.

Una alternativa posible sería la realización de una perforación de captación en las cercanías del barrio, a cargo y bajo control de OST. La zona de explotación debe poseer la menor afectación posible de fuentes contaminantes hacia el recurso subterráneo. Debe asegurarse la cantidad y calidad del mismo, a fin de abastecer sin inconvenientes a toda la comunidad barrial.

En cuanto a la explotación de agua, se requiere el control y otorgamiento de permisos para la realización de perforaciones, tal como lo establece el Código de Aguas, Ley 12.257 (Título II, artículos 25, 57 y 82 a 87), especialmente cuando las mismas abastecerán al consumo de poblaciones sin agua potable.

Tanto en las perforaciones existentes como aquellas a construir, es necesario el análisis periódico de la calidad del agua, según los parámetros para consumo humano establecidos en la legislación argentina. A partir de allí, debe procurarse el abastecimiento de agua potable en las viviendas con evidencias de contaminación química y/o microbiológica, especialmente en aquellas con presencia de población más susceptible, tales como niños, ancianos o embarazadas.

En relación con el uso del agua y la generación de efluentes domiciliarios, es fundamental el control y asesoramiento sobre la construcción y funcionamiento de los sistemas domiciliarios de disposición de efluentes. El tratamiento de las aguas residuales domiciliarias debe ser entendido, como una necesidad, a fin de mantener condiciones adecuadas de salud e higiene para la población, y conservar la calidad del recurso subterráneo.

Considerando que otra de las fuentes de contaminación del agua está constituida por los residuos sólidos, se requiere el control de los sitios de disposición conjuntamente con el manejo de los mismos, tendiente a evitar la generación y crecimiento de basurales espontáneos así como la disposición en cavas de canteras localizadas en el barrio.

Todas las estrategias comunitarias requerirán de consenso, por lo cual será útil la formación de un grupo de acción y decisión, en el que participen diferentes actores del proceso de gestión, incluyendo habitantes del barrio, representantes de los 
establecimientos locales, del Centro Comunitario, del Gobierno local, de instituciones de salud, de OST, entre otros.

Además, las estrategias deben basarse en información fidedigna sobre la problemática hídrica local, por lo cual será de suma utilidad la evaluación y el monitoreo de los indicadores de sustentabilidad antes planteados.

\subsubsection{Educación ambiental, capacitación y transferencia}

Para lograr la concientización de la población local sobre las estrategias de gestión ambiental propuestas, se requiere la transferencia de los resultados obtenidos en el diagnóstico ambiental, la realización de tareas de educación ambiental en general y la capacitación específica sobre cuestiones técnicas para el manejo del agua.

De ese modo, deben continuarse las actividades detalladas en el ítem 5.2, en forma de charlas y talleres en todos los niveles educativos y para la comunidad en general, en temas como: saneamiento y desinfección de tanques y cañerías; potabilización; enfermedades hídricas; manejo de residuos sólidos; medidas estructurales relacionadas al almacenamiento y distribución de agua así como a la construcción de perforaciones y pozos absorbentes; importancia de la participación ciudadana en la toma de decisiones; entre otras.

Asimismo, será útil la difusión en los medios locales de comunicación (radiales, televisivos, gráficos y escritos) de las medidas a tener en cuenta para el uso del agua, factibles de realizar por los habitantes.

\subsubsection{Diseño y construcción de las perforaciones de captación}

Se entiende por diseño de pozo a todas las consideraciones o requisitos básicos tenidos en cuenta para realizar una perforación. Incluye diversos criterios técnicos, como la protección del pozo de toda fuente de contaminación, a partir del sellado o aislamiento de capas; la construcción adecuada según el caudal de extracción, considerando especialmente la profundidad y el diámetro correctos; y la elección de los materiales según condiciones de resistencia y durabilidad.

El objetivo a la hora de realizar una perforación de captación es obtener la mejor posible para los fines previstos, de forma tal que sea lo más eficiente y económica de acuerdo a la hidrogeología local.

Es fundamental comenzar por recabar y analizar la información hidrogeológica disponible. De ser necesario, sobre todo en perforaciones de uso público, se pueden 
realizar pozos piloto o de observación que permitan obtener información relevante con anterioridad a la realización del pozo de explotación.

El diseño se inicia con el análisis e interpretación de las características y gradación de los materiales que integran el acuífero. Es indispensable la realización de un ensayo de bombeo, el cual permite establecer las características del acuífero, conocer su funcionamiento y determinar la correcta construcción del pozo.

A partir de allí, los parámetros de diseño se basan en la información sobre los materiales que constituyen el acuífero, sus características y funcionamiento. A continuación se describen algunos de los criterios más relevantes según Ahrens (1957) y Custodio y Llamas (1976).

- Localización: la perforación debe ubicarse preferentemente en un lugar alto, de acceso fácil para inspección, reparación y mantenimiento de los equipos de bombeo y de la perforación en sí. Además, debe respetar distancias mínimas respecto a sitios de disposición y tratamiento de efluentes, edificaciones, árboles de gran tamaño, cursos de agua, entre otros.

- Diámetro del pozo: tiene relación directa con el éxito de la construcción. Debe ser suficientemente amplio para facilitar la instalación y el correcto funcionamiento de la bomba, y debe asegurar un funcionamiento hidráulico completo.

- Profundidad del pozo: generalmente se perfora hasta la base de la formación acuífera, para obtener una mayor eficiencia.

- Características de los caños filtros: representa una de las partes más importantes de un pozo puesto que de esto dependen en una gran proporción las condiciones hidráulicas de la captación. Se ubicará en la parte inferior del acuífero. Deben tener una longitud, diámetro y ranuras adecuados según las características geohidrológicas analizadas. Además, existen diferentes tipos de filtros y varias opciones de calidad.

- Utilización de prefiltro de grava: en algunos casos las características granulométricas de la formación requieren un prefiltro de grava, el cual retiene el material de la formación, favorece el soporte lateral del filtro, y evita el desmoronamiento o desprendimiento de material de la formación. Para su elección deben considerarse especialmente la calidad y el tamaño de la grava.

- Revestimiento: la perforación deberá ser provista de un revestimiento o cañería de entubación que funciona como parte de la estructura del pozo dándole la hermeticidad necesaria para su protección. Estas cañerías se conocen comúnmente como "encamisado o caños camisa"; Los objetivos son minimizar las posibles fuentes de contaminación, retener las paredes del pozo y facilitar el escurrimiento vertical del agua hacia y hasta la aspiración de la bomba. 
- Cementación: se realiza con el fin de sellar el espacio anular entre la cañería de entubado y las paredes del pozo. El material más usado es una lechada de cemento y en algunos casos se suele agregar bentonita.

- Terminación y protección superficial: el entubado deberá sobresalir unos 25 centímetros como mínimo sobre el piso y que cualquier conducto que comunique con el pozo debe cumplir condiciones de hermeticidad. Además, es importante una buena plataforma para mantener el alineamiento de la bomba. Se requiere la cobertura superficial, mediante una tapa que impida el ingreso de las precipitaciones así como de cualquier sustancia o elemento a la perforación.

\subsubsection{Sistemas de distribución y almacenamiento de agua}

Además de proteger la fuente de agua, se requiere la correcta construcción y mantenimiento de los sistemas de distribución y almacenamiento en los domicilios. Como se detalló en el ítem 4.5, sobre las condiciones de explotación y uso del agua, en numerosas viviendas del Barrio Cerro Los Leones, existen deficiencias en las cañerías de distribución del agua, así como en el tanque de reserva de la misma. Esto posibilita la contaminación, especialmente microbiológica, en las etapas de trasporte y almacenamiento, e incluso durante el consumo del agua.

La estrategia primordial consiste en la educación sanitaria de la comunidad. Se deben difundir medidas claras de higiene, así como asesorar en la correcta construcción del sistema de distribución del agua, la hermeticidad en los tanques, de modo de evitar las pérdidas, las fuentes de contaminación y promover la limpieza y mantenimiento de los depósitos de almacenamiento.

\subsubsection{Desinfección y potabilización}

La desinfección es un proceso cuyo objetivo es obtener agua exenta de bacterias y organismos patógenos, conforme a las normas establecidas. A continuación se plantean medidas relacionadas con dicho proceso, pudiendo ser algunas de ellas aplicables al área de estudio.

Para comenzar, y dentro de las estrategias de educación y capacitación, deben fomentarse las tareas de desinfección de tanques, cañerías y perforaciones, así como la utilización de clorinadores para la dosificación adecuada de cloro en los tanques domiciliarios. Como medida complementaria y necesaria para el éxito de la desinfección, podría realizarse la entrega periódica de un derivado de cloro a aquellos habitantes con dificultades económicas para su adquisición. Esta tarea requiere el asesoramiento adecuado sobre la manipulación y uso del mismo, en tanto puede implicar riesgos para la salud. 
En cuanto a la contaminación microbiológica, la mejor manera de combatirla es mediante la prevención, por medio de la eliminación de las fuentes de contaminación y a través de programas continuos de educación ambiental.

En aquellos casos que se evidenciaron microorganismos patógenos en agua, incluso superando los parámetros establecidos por la legislación, se debe garantizar la desinfección. Para ello pueden utilizarse diferentes métodos, desde tareas sencillas como el hervor del agua o la exposición de la misma al sol, pasando por la cloración y filtros de arena hasta la ozonización. La opción de hervir el agua, garantiza la desinfección, pero puede no ser adecuada en casos donde hay elevada cantidad de sales disueltas o algún ión supera los valores recomendados.

La cloración, por su parte, es un método muy utilizado, caracterizado por su eficacia, economía y facilidad de aplicación, apto para viviendas particulares así como instituciones y establecimientos educativos. Brinda la posibilidad de mantener tenores del producto activo por cierto tiempo, de manera de continuar con el efecto desinfectante en la red de distribución. Su aplicación debe realizarse con una frecuencia establecida y bajo supervisión o asesoramiento (UNICEF, 1999). La elección del desinfectante depende de criterios técnicos y económicos. Algunos de los utilizados son derivados del cloro, como los hipocloritos sódico y cálcico. (Barraque et al., 1979). La cloración doméstica presenta la dificultad en el control de la dosificación. La sobredosificación puede conducir a la ocurrencia de trastornos estomacales e irritación dérmica y la generación de un sabor poco agradable. Además, pueden producirse inconvenientes, especialmente olores, mal sabor, o reacciones químicas, en caso de que las aguas estén contaminadas por compuestos orgánicos.

Por su parte, los rayos ultravioletas permiten una eliminación completa de los virus. De ese modo, la desinfección solar es una tecnología básica que utiliza la radiación solar natural para inactivar y destruir los microorganismos patógenos en el agua, por medio de la combinación de rayos ultravioleta (UV) y calor. El tratamiento es generalmente para uso doméstico y de bajo costo. Para que el sistema resulte efectivo, éste debe formar parte de un intenso programa de movilización social y educativa que asegure su aplicación correcta y de manera consistente (UNICEF, 1999).

Por otro lado, el ozono es un excelente desinfectante. Si bien su costo es más elevado que el cloro o sus compuestos, su eficacia es muy superior (Barraque et al., 1979). Su acción de ozonólisis le permite actuar sobre los virus, los sabores, el color y sobre ciertos microcontaminantes.

La potabilización es un término más amplio que la desinfección, pues además de la eliminación o reducción de organismos patógenos, también incluye la garantía de que las 
características físico-químicas del agua respetan los niveles recomendados para el consumo humano. Una alternativa útil son los filtros de arena, efectivos para eliminar o reducir tanto sustancias orgánicas como inorgánicas en suspensión. Éstos pueden ser a escala comunitaria o domiciliarios. Son muy utilizados para filtración de aguas con cargas bajas o medianas de contaminantes. Las partículas en suspensión son retenidas durante su paso a través de un lecho filtrante de arena y el agua filtrada pasa dentro del colector de descarga, ubicado en el fondo de los tanques. Asimismo, los filtros lentos de arena tienen tasas de separación de hasta un 99,99 \% para quistes de Giardia y Cryptospiridium. Este hecho brinda una ventaja sabiendo que los quistes de Giardia tienen cierta resistencia a la cloración (Kiely, 2001).

Otra alternativa es el uso de carbón activado, que se utilizan principalmente para eliminación de cloro residual y compuestos orgánicos en el agua. El sistema de funcionamiento es similar al de los filtros de arena, realizándose la retención y adsorción de contaminantes del agua al pasar por un lecho filtrante compuesto de carbón activado.

Para reducir la concentración de nitratos en las aguas subterráneas, debe comenzarse por la prevención, es decir evitando o reduciendo las fuentes de contaminación. En el caso del Barrio Cerro Los Leones, se han detectado niveles de nitratos superiores al valor recomendado por el Código Alimentario Argentino. En esas situaciones, se pueden seguir varias alternativas, tales como plantea Gray (1994). Una de ellas es sustituir las fuentes de obtención de agua por otras con menores contenidos de nitratos, aunque puede resultar costoso al requerir nuevas perforaciones y cañerías. Otra alternativa incluye el mezclado, es decir la reducción controlada de nitratos a una concentración aceptable por la dilución del agua con otra con menores tenores. Esta práctica la realiza Obras Sanitarias Tandil para el abastecimiento en determinados sectores de la ciudad.

Dentro de las opciones de tratamiento, los nitratos pueden eliminarse por intercambio iónico o desnitrificación microbiana. Ambos son caros y de operación en continuo. El sistema de intercambio iónico es eficiente, pero genera un efluente concentrado de salmuera que exige un tratamiento posterior y un vertido controlado. Asimismo, la ósmosis inversa es una tecnología de purificación de agua mediante la cual se logra un elevado porcentaje de retención de contaminantes, disueltos y no disueltos.

Como se indicó en las pautas de planificación, una estrategia sencilla sería la identificación en la comunidad de aquellas perforaciones con mayores niveles de nitratos, superiores a $45 \mathrm{mg} / \mathrm{l}$. Así, podría suministrarse agua segura, sea embotellada o trasportada en camiones cisterna. Esta alternativa está siendo aplicada en el Barrio Cerro Los Leones, donde OST abastece de agua potable a las viviendas con problemas en las perforaciones o antecedentes de contaminación bacteriológica. 


\subsubsection{Disposición y tratamiento de efluentes domiciliarios}

Cabe considerar que el manejo apropiado de los efluentes domiciliarios puede reducir la contaminación del agua subterránea y por ende contribuir a la disminución de la transmisión y contagio de enfermedades hídricas. La solución más pertinente para la evacuación de los efluentes, sería la conexión a una red cloacal, que los recolecte, trate y disponga correctamente. Pero en casos de localidades como la estudiada en este trabajo, diversas circunstancias tanto sociales, económicas, como tecnológicas lo vuelven difícil.

Los pozos absorbentes, utilizados predominantemente en la zona de estudio, sean más o menos permeables, son especialmente aptos para suelos areno-arcillosos o loess arcillosos, y para recibir los efluentes provenientes de una cámara séptica originados en una vivienda familiar. Requieren protección y paramentos de ladrillos, piedras u hormigón armado, para evitar el desmoronamiento del pozo y permitir el pasaje del efluente hacia el terreno. Los inconvenientes que presentan en su uso, se deben a la necesidad de extracción de los sólidos y su posterior eliminación, así como a la generación de olores (Hernández Muñoz et al., 2004). Cuando los suelos lo requieren, deben ser protegidos con ladrillos, piedras o estructuras de hormigón para evitar su desmoronamiento y permitir el paso del efluente hacia el terreno.

Como se enunció precedentemente, diversos autores recomiendan un distanciamiento mínimo entre los pozos absorbentes y las perforaciones de captación para consumo humano. No obstante, deberían conocerse las características del sitio, para ajustar estos valores.

En situaciones sanitarias como la abordada en este trabajo, deben construirse los sistemas domiciliarios según criterios de protección del recurso subterráneo. Es fundamental la utilización de cámaras sépticas como primera etapa del tratamiento. Dicha cámara, conjuntamente con la infiltración en el subsuelo, constituye un sistema efectivo y económico factible de ser utilizado en viviendas individuales (Mariñelarena, 2006). La cámara séptica tiene varias funciones principales: la intercepción de los sólidos, la digestión de los que sedimentaron, el almacenamiento de aquellos digeridos y la degradación de la espuma. Su funcionamiento y mantenimiento adecuado permiten una importante reducción de la DBO5, la DQO, los sólidos sedimentables, grasas y aceites. Esa capacidad de disgregación y decantación del efluente, constituye sólo un tratamiento primario, por lo cual requiere la continuación del proceso de depuración.

Hernández Muñoz et al. (2004) describen un tratamiento de efluentes domiciliarios apto para una pequeña depuradora comunitaria, hasta 300 habitantes, tal como en la zona de estudio. Consiste también en una cámara séptica, de mayor magnitud, cuyo sistema consta de tres compartimentos, en los dos primeros se realiza el tratamiento primario 
mientras que en el restante el secundario por degradación aeróbica. El resultado más importante del proceso se basa en la considerable reducción del volumen de los sólidos, que permite el funcionamiento de la cámara por períodos de entre uno y cuatro años sin requerir limpieza. La instalación y funcionamiento de estos sistemas depende del diseño, el volumen y tipo de carga contaminante recibida, los aspectos topográficos y geológicos, el tipo de suelo, la profundidad del nivel freático, y la proximidad a las zonas pobladas.

Una vez que el efluente ha atravesado este tipo de cámaras, sean unifamiliares o comunitarias, debe continuar su depuración a través de la disposición del mismo en el suelo, el cual posee gran eficiencia en la remoción de los organismos patógenos. Existen diversas alternativas, tales como los terrenos y pozos filtrantes, los lechos bacterianos y filtros de arena. La selección debe responder a diversos factores, como la permeabilidad del suelo, la pendiente, la profundidad del nivel freático, el tipo de suelo, la profundidad del subsuelo rocoso, los caudales recibidos y sus variaciones, y la distancia a las perforaciones de captación, como se indicó anteriormente.

La alternativa del terreno de infiltración, como segunda etapa de tratamiento luego de la cámara séptica, es descrita por Mariñelarena (2006). Requiere su localización en una zona alta, que no esté sujeta a inundaciones o encharcamiento, y a determinadas distancias de perforaciones y cursos de agua. Antes de decidir la construcción de este sistema de tratamiento, se requiere el conocimiento de las características del suelo, especialmente su capacidad de infiltración, y la profundidad del nivel freático. El mismo autor establece pautas sencillas para la autoconstrucción de estos sistemas de tratamiento, desde su dimensionamiento, la construcción de la cámara séptica y el terreno de infiltración, hasta su puesta en marcha y funcionamiento.

Por otro lado, los pozos filtrantes reciben el efluente procedente de la cámara séptica, permitiendo la depuración aeróbica y reteniendo las partículas en suspensión. Este sistema es apto cuando el terreno está constituido por gravas, arenas gruesas o medianas. Por su parte, los lechos bacterianos permiten la oxidación de la materia orgánica mediante bacterias aerobias fijadas en arenas o gravas, recibiendo la aireación natural adecuada.

Cabe aclarar que estas alternativas de tratamiento de efluentes, se enfocan especialmente en la eliminación de la carga bacteriológica y orgánica vertida sobre el suelo. Sin embargo, no logran disminuir el incremento salino provocado por las concentraciones de nitratos y cloruros contenidas en los líquidos domiciliarios. Esta situación se ve claramente reflejada en la zona de estudio, a través del aumento del ión nitrato en las perforaciones de captación ubicadas en la zona de mayor densidad de pozos absorbentes. Por lo tanto, pueden requerirse tratamientos adicionales tendientes a la eliminación o reducción de sales presentes. 


\section{CONCLUSIONES Y RECOMENDACIONES}

La presente tesis se basó en la evaluación ambiental de las condiciones de explotación y uso del recurso hídrico subterráneo en el barrio Cerro Los Leones, ubicado en el Partido de Tandil, en la periferia de la ciudad homónima.

En la zona la población se abastece de agua subterránea para diversos usos, incluyendo el consumo. El interés en ella surgió a partir del conocimiento de la ausencia de los servicios sanitarios básicos, así como de los antecedentes de contaminación bacteriológica del agua.

A lo largo del desarrollo de la investigación, se analizó de manera sistémica la dinámica ambiental, en particular la problemática hídrica presente. Partiendo de la concepción del ambiente como interrelación sociedad-naturaleza, se tuvieron en cuenta dos ejes para el diagnóstico, uno basado en el subsistema físico-natural, principalmente hidrogeológico, y otro en el factor humano que actúa sobre dicho medio, y lo altera.

En lo que respecta al medio natural, se ha evaluado la hidrodinámica subterránea y la calidad del recurso para el consumo humano, en función de parámetros físico-químicos y microbiológicos.

La dinámica subterránea en la zona del Barrio Cerro Los Leones, presentó un movimiento del agua en concordancia con el flujo regional, en sentido SO-NE. Las líneas equipotenciales demarcaron un flujo radial convergente desde las sierras hacia el barrio, con tendencia a volverse paralelo aguas abajo. En general, la profundidad del nivel freático en el sector no sobrepasó los 10 metros. Los niveles piezométricos variaron entre 198 y 225 metros. A lo largo del lapso de estudio, se observó un descenso paulatino de los mismos, de acuerdo a la escasez de precipitaciones y al déficit hídrico ocurrido durante el período.

Respecto a la hidroquímica, los valores de conductividad eléctrica oscilaron entre 680 y $1030 \mathrm{uS} / \mathrm{cm}$. Como se presentó en la cartografía, los mayores valores se encontraron en el centro del barrio, donde se concentran los focos contaminantes. Todos los iones mayoritarios presentaron valores de acuerdo a las características del recurso hídrico a nivel regional y no superaron los parámetros recomendados para consumo humano. Esto permitió clasificar a las aguas subterráneas de la zona como bicarbonatadas cálcicas-magnésicas y, dada su baja salinidad, se consideraron jóvenes. Sin embargo, las concentraciones de nitratos variaron desde $10 \mathrm{mg} / \mathrm{l}$ hasta $110 \mathrm{mg} / \mathrm{l}$, superando en muchos casos el límite establecido en el Código Alimentario Argentino, resultando no aptas para el consumo humano. 
Se pudo apreciar, a partir de la cartografía elaborada, la coincidencia entre la zona con mayores valores de conductividad eléctrica y con elevados tenores de nitratos. Esta situación se explica considerando el sentido de escurrimiento subterráneo local, debido a que el agua fluye hacia el NE, atravesando la zona de mayor densidad poblacional y transportando las cargas contaminantes desde la zona alta del barrio hacia la parte central del mismo, incrementando la concentración del ión nitrato y por ende la salinidad del agua.

Considerando la homogeneidad regional del sistema subterráneo así como las características del recurso hídrico a nivel de cuenca y del asentamiento urbano, la alteración en la hidroquímica subterránea local se produce esencialmente por la disposición in situ de las cargas contaminantes de los efluentes en pozos absorbentes y la simultánea extracción del agua de consumo a través del sistema puntual de abastecimiento mediante pozos de bombeo individuales, lo que genera un ciclo local semicerrado.

Esta situación evidencia claramente la contaminación del acuífero a partir del uso y gestión del recurso hídrico en forma inapropiada., lo que permite remarcar la importancia de la evaluación de la concentración de nitratos en las aguas subterráneas analizadas, por sus potenciales efectos sobre la salud de la población que las consume.

Asimismo, los resultados microbiológicos permitieron comprobar la degradación de la calidad del agua, ya que el 78\% de las muestras no resultó apto para el consumo humano, según lo establecido en el Código Alimentario Argentino. De ese modo, se determinó que gran parte de la población que ingiere el recurso se encuentra en riesgo elevado de contraer enfermedades hídricas relacionadas con la presencia de agentes patógenos.

El segundo eje del diagnóstico, lo constituyó el subsistema social local, caracterizado por un grupo de alrededor de 300 habitantes que utilizan el recurso subterráneo para diversos usos, tanto domésticos como productivos, inmersos en una red de actores vinculados a la gestión del agua, la cual resultó sumamente compleja.

Una serie de factores, entre los que se incluyen la ausencia de servicios de agua potable y red cloacal; la falta de difusión e información a la población; las debilidades en la gestión municipal; así como las dificultades socioeconómicas de los habitantes del barrio, genera ciertas condiciones de explotación y uso del agua a nivel local. Se han evidenciado numerosas deficiencias en lo referido al diseño, construcción y funcionamiento de las perforaciones de captación, del mismo modo que los sistemas de distribución y almacenamiento presentan inconvenientes en su construcción y mantenimiento. Por otra parte, los efluentes domiciliarios constituyen la principal fuente 
de contaminación del acuífero, siendo dispuestos principalmente en pozos absorbentes que también carecen de un diseño y funcionamiento adecuados.

A partir de dichos modos de explotación y uso, se corroboraron alteraciones en el funcionamiento del sistema hidrológico, siendo la calidad del agua uno de los principales factores afectados, tal como se identificó a través de los análisis físico-químicos y microbiológicos. Esta situación determina la contaminación de un recurso vital para los habitantes del lugar.

En síntesis, en la presente investigación, se ha puesto de manifiesto la relación existente entre las condiciones de uso del recurso hídrico subterráneo y la calidad del mismo, corroborándose la interconexión hidráulica entre los pozos de captación y los absorbentes. Debido al diseño inadecuado de las perforaciones, la ausencia de medidas de saneamiento, la disposición de efluentes en el suelo y el escaso distanciamiento entre los pozos absorbentes y los sitios de captación de agua, se presenta contaminación bacteriológica y química, especialmente referida a nitratos, en la mayoría de las muestras analizadas pertenecientes al Barrio Cerro Los Leones.

De este modo, queda confirmada la hipótesis previamente planteada referida a la contaminación química y bacteriológica del recurso hídrico subterráneo, ocasionada por los modos de explotación y uso del mismo así como la falta de saneamiento básico, cuestiones derivadas de la falta de planificación y gestión sustentable.

Ante este diagnóstico y teniendo en cuenta que la ecohidrología es una ciencia que busca soluciones o alternativas ante problemáticas ambientales que involucran los recursos hídricos y la población, se llevó adelante la generación de pautas de gestión sustentable, lo que constituyó el objetivo general de la presente tesis. A partir de un abordaje sistémico, se establecieron tres lineamientos principales.

En primer lugar y en relación a la educación ambiental y transferencia de resultados, se realizaron actividades de capacitación en ámbitos formales y no formales. Las mismas se basaron en la comprensión del funcionamiento del sistema hídrico, así como en el conocimiento de la problemática ambiental local. Se hizo hincapié en las acciones a desarrollar ante las actuales condiciones de explotación y uso del agua, tendientes a evitar la transmisión de enfermedades hídricas, la preservación del recurso y la mejora de la calidad de vida. El acercamiento con la comunidad a lo largo del trabajo, permitió conocer la percepción social del ambiente y facilitó la aplicación de las recomendaciones brindadas en la capacitación.

En segundo lugar, y considerando que el análisis de las problemáticas ambientales no debe ser estático, sino que debe evaluarse su continuidad y evolución temporal, se 
elaboraron indicadores básicos de sustentabilidad, basados en el Modelo de PresiónEstado-Respuesta, que constituyen la base para futuras estrategias de gestión sustentable de los recursos hídricos, y son útiles para aplicar en otros sectores urbanos y rurales de similares características.

Esta serie de indicadores permitirá el monitoreo futuro de las variables de interés, referidas a las presiones humanas sobre el recurso hídrico subterráneo, los impactos ambientales resultantes de dichas presiones, así como las respuestas de los diferentes actores sociales ante la problemática local.

El tercer lineamiento, se basó en una serie de medidas estructurales y no estructurales tendientes al mejoramiento de los modos de uso del agua, tanto alternativas como recomendaciones posibles de llevar a cabo acordes a la realidad del área de estudio.

Se incluyeron estrategias de planificación, evaluación, control y seguimiento sobre los modos de explotación y uso del recurso, las que deben ser encaradas por los diferentes niveles gubernamentales así como por las instituciones relacionadas. Estas pautas brindan el marco general para la puesta en práctica de otras propuestas, especialmente las destinadas a la continuación y desarrollo de tareas de capacitación y concientización de la población acerca de la problemática ambiental local y las posibles medidas a tomar al respecto. Además, se plantearon acciones preventivas y de mitigación, basadas en el diseño y protección sanitaria de las perforaciones de captación, la construcción de sistemas de distribución y almacenamiento de agua, las tareas de desinfección y potabilización, y la disposición y tratamiento adecuado de efluentes domiciliarios.

La presente investigación se ha basado en el diagnóstico integral de la dinámica del sistema ambiental, fundado en los pilares de equidad social, desarrollo económico y preservación y protección de los recursos naturales, sentando las bases para la generación de pautas de gestión sustentable del agua y demostrando la importancia de este trabajo tanto en el campo de la ecohidrología así como en el de las ciencias ambientales en general. 


\section{REFERENCIAS}

\subsection{Bibliografía}

- Ahrens, T. P. (1957) Criterios para el diseño de perforaciones de agua. Traducido del original: "Water well design criteria" por M. P. Auge. Consejo Federal de Inversiones. Publicación original del Water Well Journal, en los números de septiembre y noviembre de 1957 y noviembre y diciembre de 1958 .

- Allen, A (1996). Introducción Teórica al Desarrollo Urbano Sustentable. M1: Teoría y Metodología de la Gestión Ambiental del Desarrollo Urbano. Maestría en GADU. Facultad de Arquitectura, Urbanismo y Diseño. Universidad Nacional de Mar del Plata. Centro de Investigaciones Ambientales (CIAM). p. 5-53. Mar del Plata, Argentina.

- APHA, AWWA, WPCF. (1992). Métodos normalizados. Para el análisis de aguas potables y residuales. Ediciones Díaz de Santos S.A. Madrid, España.

- AYDET S.A. y Facultad de Ciencias Humanas de la Universidad Nacional del Centro de la Provincia de Buenos Aires - UNCPBA. (2004). Plan de ordenamiento territorial del Municipio de Tandil.

- Banda Noriega, R., Ruiz de Galarreta, A., Barranquero, R., Díaz, A., Miguel, E., Rodríguez, C. I. (2008). Caracterización de cargas contaminantes generadas en Tandil y su implicancia en el recurso hídrico. Buenos Aires, Argentina. II Congreso Internacional sobre Gestión y Tratamiento Integral del Agua. Trabajo completo en CD Libro ISBN 978-987-1253-44-9. p. 451-463. Córdoba, Argentina.

- Barranquero, R. (2005). Calidad del agua de consumo en la ciudad de Tandil. Tesis de Licenciatura en Diagnóstico y Gestión Ambiental. Facultad de Ciencias Humanas. Universidad Nacional del Centro de la Provincia de Buenos Aires. 178 p. Tandil, Buenos Aires, Argentina.

- Barranquero, R., Ruiz de Galarreta, A., Banda Noriega, R. (2006). Evaluación de nitratos en los pozos de explotación en la ciudad de Tandil, Buenos Aires, Argentina. VIII Congreso Latinoamericano de Hidrología Subterránea. Trabajo completo en CD. 21 p. Asunción, Paraguay.

- Barranquero, R., Miguel, E., Ruiz de Galarreta, A., Varni, M. (2008a). Influencia de la explotación local del recurso hídrico subterráneo sobre la hidrodinámica regional en Tandil, Buenos Aires, Argentina. IX Congreso Latinoamericano de Hidrología Subterránea y Expo Agua 2008. Trabajo completo en CD ROM. Quito, Ecuador.

- Barranquero, R., Varni, M., Banda Noriega, R., Ruiz de Galarreta, A., Quiroga, M. y Landa, R. (2008b). Caracterización hidroquímica de las aguas subterráneas en la cuenca del arroyo Langueyú, Partido de Tandil, Buenos Aires. Actas del II Congreso Argentino de la Sociedad de Toxicología y Química Ambiental (SETAC). Póster. Mar del Plata, Argentina.

- Barranquero, R., Varni, M., Ruiz de Galarreta, A. (2009). Evaluación de las fluctuaciones del nivel freático en la cuenca del arroyo Langueyú, Partido de Tandil. VI Congreso Argentino de Hidrogeología. Trabajo completo en CD ROM. Santa Rosa, La Pampa. 
- Barranquero, R. (2009). Análisis hidrogeológico y evaluación de cargas contaminantes en la cuenca del arroyo Langueyú. Tesis de Maestría en Ciencias Hídricas. Universidad Nacional de La Pampa. 172 p. Argentina.

- Barraque, Ch. y otros (1979). Manual técnico del agua. Tratamiento de las aguas de consumo. Ed. Degremont. 77 p. Salamanca, España.

- Berger, A. R. y Iams, W. J. (1996). Geoindicators. Assessing rapid environmental changes in earth systems. A.A. 466 p. Balkema, Rotterdamm. Netherlands.

- Bertoni, D. (2009). Vulnerabilidades en la gestión del servicio de agua potable y/o corriente de Coronel Dorrego. Tesis de Licenciatura en Gestión Ambiental. Facultad de Ciencias Humanas. Universidad Nacional del Centro de la Provincia de Buenos Aires. 153 p. Tandil, Buenos Aires, Argentina.

- Blarasin, M., Cabrera A. y Felizzia, J. (2002). Geoindicadores y problemática ambiental urbana relacionada a cambios de niveles y calidad de aguas subterráneas. Taller sobre geoindicadores y aplicación en campo. Actas en CD ROM. Córdoba.

- Bukosky, M. (2008). Vulnerabilidades en la gestión del servicio de agua potable de la localidad de Oriente. Tesis de Licenciatura en Gestión Ambiental. Facultad de Ciencias Humanas. Universidad Nacional del Centro de la Provincia de Buenos Aires. 103 p. Tandil, Buenos Aires, Argentina.

- Catalán Lafuente, J. G. (1969). Química del agua. Editorial Blume. 355 p. España.

- Código Alimentario Argentino. (1969). Ley 18.284. Actualizado en 2007. Capítulo XII: Bebidas hídricas, agua y agua gasificada. 65 p. Argentina.

- Consejo Federal de agua potable y saneamiento (CoFAPyS). Ministerio de Economía y obras y servicios públicos. (1993). Normas de estudio, criterios de diseño y presentación de proyectos de desagües cloacales para localidades de hasta 30.000 habitantes. Fundamentación de normas, Vol. II: 7.70 p. Argentina.

- Conferencia de las Naciones Unidas sobre el Medio Ambiente y el Desarrollo (1992). Declaración de Río sobre el Medio Ambiente y el Desarrollo. Río de Janeiro, Brasil.

- Conferencia Intergubernamental sobre Educación Ambiental (1977). Octubre de 1977. Informe final. Organización de las Naciones Unidas para la Educación, la Ciencia y la Cultura (UNESCO). 103 p. Tbilisi. URSS.

- Custodio, E. y Llamas, M., (1976). Hidrología Subterránea. 2 Tomos. Ediciones Omega. 2359 p. Barcelona, España.

- Custodio, E. (1997). Evaluación de la recarga por la lluvia mediante métodos ambientales químicos, isotópicos y térmicos. En: La evaluación de la recarga a los acuíferos en la Planificación Hidrológica. AIH-GE. p. 83-109. Las Palmas de Gran Canaria, España.

- Dalla Salda, L. (1999). Cratón del Río de la Plata. 1. Basamento granítico - metamórfico de Tandilia y Martín García. Geología Argentina. Instituto de Geología y Recursos minerales. Anales 29 (4): 97-106. Buenos Aires, Argentina. 
- Dalla Salda, L., de Barrio, R. E., Echeveste, H. J., Fernández, R. (2005). El basamento de las sierras de Tandilia. Geología y recursos minerales de la Provincia de Buenos Aires. Relatorio del XVI Congreso Geológico Argentino. Cap. III: 31-50. La Plata.

- Davis, S. N. y De Wiest, R. (1971). Hidrogeología. Ediciones Airel. 563 p. Barcelona, España.

- Di Pace, M. (2001). Sustentabilidad urbana y desarrollo local. Módulo 4, Curso de postgrado en Desarrollo local de áreas metropolitanas. Instituto del Conurbano, Universidad Nacional de General Sarmiento. 40 p. Buenos Aires.

- Dirección de Bromatología del Municipio de Tandil. 2004-2007. Análisis microbiológicos de aguas realizados sobre muestras de aguas subterráneas de diferentes viviendas e instituciones del Barrio Cerro Leones.

- Dourejeanni, A. (2000). Procedimientos de gestión para el desarrollo sustentable. Serie 10 Manuales. División de recursos naturales e infraestructura. Comisión Económica para América Latina y el Caribe (CEPAL). Naciones Unidas. ISBN: 92-1-321637-8. 128 p. Chile.

- Dourejeanni, A. (2002). ¿Quién gobierna a quién en la gestión del agua?. CEPAL. Naciones Unidas. Foro de los Recursos Hídricos. Primer Encuentro Nacional. El agua un derecho para todos. 42 p. Quito, Ecuador.

- Fernández, R. J. (1998). La ciudad verde: Manual de gestión ambiental urbana. Programa editorial del Centro de Investigaciones Ambientales (CIAM). Facultad de Arquitectura, Urbanismo y Diseño. Universidad Nacional de Mar del Plata. 389 p. Buenos Aires, Argentina.

- Fidalgo, F., De Francesco, F. O., Pascual, R. (1975). Geología Superficial de la Llanura Bonaerense. Geología de la provincia de Buenos Aires. Relatorio del VI Congreso Geológico Argentino. p. 103-108. Bahía Blanca, Buenos Aires.

- Fidalgo, F. (1983). Algunas características de los sedimentos superficiales en la Cuenca del Río Salado y la Pampa Ondulada. Hidrología de las grandes llanuras. Organización de las Naciones Unidas para la Educación, la Ciencia y la Cultura (UNESCO). Vol. II: 1043-1067. Argentina.

- Fontana, O. L. (1947). Tandil en la historia: antecedentes completos de Tandil histórico 18231883; a la luz de los antiguos manuscritos del Archivo municipal de la localidad. Talleres Vitullo, Vistali y Cia. p. 164-168. Tandil.

- Gallo, M. A., Villalobo, M. C., Spampinato, M. F. (2004). Caracterización fisicoquímica y bacteriológica de las aguas del Partido de Tandil. Dirección de Bromatología, Municipio de Tandil. Congreso Nacional de Bromatología Municipal. Asociación de Jueces Municipales de Faltas de la Provincia de Bs. As. Mar del Plata, Buenos Aires.

- Gallopin, G. (2003). Sostenibilidad y desarrollo sostenible: un enfoque sistémico Comisión Económica para América Latina y el Caribe (CEPAL). Serie Medio Ambiente y Desarrollo No 64: $1-44$.

- Gamazo, C.; López-Goñi, I.; Díaz, R. (2005) Manual práctico de microbiología. Tercera edición. ISBN 8445815199. Editorial Masson. 264 p. España.

- García, M. C., Bertuccelli, G., Bertuccelli, D., Martín, A. V. (2006). Riesgo a contaminantes urbanos y adaptación de tecnologías para el tratamiento. Séptimas Jornadas de Presentación de Trabajos y Extensión del Centro de Investigaciones Geográficas ( $7^{\circ}$ JOPTECIG) y Primeras 
Jornadas Nacionales de Geografía de la Argentina y sus Problemas Actuales (I JONAGAPA). Universidad Nacional del Centro de la Provincia de Buenos Aires. Actas: 22-32. Tandil, Argentina.

- García, M. C. y Martín, A. V. (2007). Nitratos en aguas de la ciudad de Tandil, y determinación de áreas de riesgo, empleando SIG. V Congreso Argentino de Hidrogeología. ISBN 978-98723936-3.2. p. 489-496. Paraná, Entre Ríos.

- García, M. C. (2008). Evaluation of the health risk from water contamination in the city of Tandil, Argentina. Springer GeoJournal. Sent: 2005. Published on-line: 2008. ISSN 0343-2521 3300. p. 289-296.

- García, R. (1994). Interdisciplinariedad y sistemas complejos. En: Ciencias sociales y formación Ambiental. Leff, E. (comp). 23 p. Barcelona, España.

- Gentile, R. O. (1995). Nuevos registros de depósitos postconquista (Cuenca del Arroyo Langueyú, Tandil, provincia de Buenos Aires). 4tas Jornadas geológicas y geofísicas bonaerenses. Vol. II: 169-185. Junín, Buenos Aires.

- Global Water Partnership - GWP (2000). Manejo Integrado de Recursos Hídricos. TAC Background Papers $\mathrm{N}^{\circ}$ 4. Estocolmo. Suecia. 80 p. Disponible on-line en : http://www.gwpforum.org/gwp/library/TACNO4.PDF

- González, N. (2005). Los ambientes hidrogeológicos de la provincia de Buenos Aires. Geología y recursos naturales de la provincia de Buenos Aires. Relatorio del XVI Congreso Geológico Argentino. Cap. XXII: 359-376. La Plata.

- Gorraiz Beloqui, R. (1958). Tandil a través de un siglo. Reseña geográfica, histórica, económica y administrativa. 1823-1923. Buenos Aires. Talleres Gráficos J. Héctor Matera. p. 155-158. Tandil.

- Gray, N. F. (1994). Calidad del agua potable: problemas y soluciones. Editorial Acribia. 365 p. Zaragoza, España.

- Guerrero, M., Jacinto, G., Banda Noriega, R., Ruiz de Galarreta, A. (2007). Sistemas de indicadores ambientales para municipios bonaerenses. Terceras Jornadas ASAUEE. Universidad Tecnológica Nacional de Tucumán. En CD ISSN 978-987-22038-1-8. Trabajo № 6: 10. Tucumán, Argentina.

- Hernández, M. A., Auge, M. P., Filí, M. F., Ceci, J. H. (1975). Geohidrología de los acuíferos profundos de la Provincia de Buenos Aires. Actas del VI Congreso Geológico Argentino. Tomo II: 479-500. Bahía Blanca, Buenos Aires.

- Hernández, M., Giaconi, L., González, N. (2002). Línea de base ambiental para las aguas subterráneas y superficiales en el área minera de Tandilia. Buenos Aires. Argentina. Congreso Internacional XXXII IAH \& VI ALHSUD Aguas Subterráneas y Desarrollo Humano. Bocanegra, E - Martínez, D - Massone, H. (Eds.). ISBN 987-544-063-9. p. 336-343. Mar del Plata.

- Hernández, M. (2005). Panorama ambiental de los recursos hídricos subterráneos en la provincia de Buenos Aires. Geología y recursos naturales de la provincia de Buenos Aires. Relatorio del XVI Congreso Geológico Argentino. Cap. XXI: 347-358. La Plata. 
- Hernández Muñoz, A., Hernández Lehman, A., Galán Martínez, P. (2004). Manual de depuración Uralita. Sistemas para depuración de aguas residuales de hasta 20000 habitantes. Thomson Editores. 429 p. Madrid, España.

- Holmberg, E. (1972) Tandilla. Simposio Geología Regional Argentina. p. 4-6. Buenos Aires.

- ICLEI - International Council for Local Environmental Initiatives (1996). Manual de planificación para la agenda 21. Una introducción a la planificación para el desarrollo sostenible. ISBN: 0968089704. 216 p. Toronto, Canadá.

- Instituto Geográfico Militar - IGM. (1955). Cartografía correspondiente a la zona del Barrio Cerro Los Leones, dentro del Partido de Tandil. Hoja Tandil, $\mathrm{N}^{\circ}$ 3760-23-4, en escala 1:50.000 y Hoja Tandil, $\mathrm{N}^{\mathrm{o}}$ 3760-23, en escala 1:100.000. Argentina.

- INDEC - Instituto Nacional de Estadísticas y Censos (2002). Censo Nacional de Población Hogares y Viviendas 2001. Resultados provisionales. Ministerio de Economía. Buenos Aires.

- INTA (1989). Mapa de suelos de la Provincia de Buenos Aires. Escala 1:500.000. SAGP-CIRN. Buenos Aires.

- Iñiguez Rodriguez, A. M. (1999). Cratón del Río de la Plata. 2. La cobertura sedimentaria de Tandilia. Geología Argentina. Instituto de Geología y Recursos minerales. Anales 29 (4): 101106. Buenos Aires, Argentina.

- Kiely, G. (2001). Ingeniería Ambiental. Fundamentos, entornos, tecnologías y sistemas de gestión. Editorial Mc Graw Hill. 1331 p. Madrid, España.

- Latella, B. (2006). Pautas generales para el manejo integrado del recurso hídrico subterráneo en Tandil. Tesis de Licenciatura en Diagnóstico y Gestión Ambiental. Facultad de Ciencias Humanas. Universidad Nacional del Centro de la Provincia de Buenos Aires. 142 p. Tandil, Buenos Aires, Argentina.

- Mariñelarena, A. (2006). Manual de autoconstrucción de sistemas de tratamiento de aguas residuales domiciliarias. FREPLATA Editores. ISBN 987-23109-0-4. 72 p. La Plata, Buenos Aires, Argentina.

- Márquez Fernández, D. (2003). De la teoría a la práctica en educación ambiental: el caso del agua. Libro del Congreso Agua y Educación Ambiental: Nuevas propuestas para la acción. p. 13 21. Alicante, España.

- Martinelli, S. M. (2004) Escuela Rural N 4, Paraje Cerro Leones, Tandil. Revista "La educación en nuestras manos", $\mathrm{N}^{\circ} 71$, mayo de 2004.

- Marzoratti, M. (2004). Calidad de las aguas subterráneas en un barrio periférico de la ciudad de Tandil. Tesis de la Licenciatura en Diagnóstico y Gestión Ambiental. Facultad de Ciencias Humanas de la Universidad Nacional del Centro de la Provincia de Buenos Aires. 103 p. Tandil, Buenos Aires, Argentina.

- Nario, H. (1982). Cortando piedra. En Todo es Historia, N 178. Marzo de 1982.

- OECD (1993). OECD core set of indicators for environmental performance reviews. Environment Monographs No. 83. OECD, Paris. 
- OECD (2003). Environmental indicators. Development, measurement and use. Reference paper. By Miriam Linster. Disponible en http://www.oecd.org/env/

- Othax, N. (2004). Análisis de la sostenibilidad en la gestión del sistema de agua de red en Rauch. Tesis de la Licenciatura en Diagnóstico y Gestión Ambiental. Facultad de Ciencias Humanas de la Universidad Nacional del Centro de la Provincia de Buenos Aires. 142 p. Tandil, Buenos Aires, Argentina.

- Penone, V., Hermida, N., Miguel, R. E., Rodríguez, C. I. (2009). Análisis preliminar del recurso hídrico subterráneo en un barrio del sector sur interserrano de la ciudad de Tandil. VI Congreso Argentino de Hidrogeología. Trabajo completo en CD ROM. Santa Rosa, La Pampa.

- Poiré, D. G. y Spalletti, L. A. (2005). La cubierta sedimentaria precámbrica-paleozoica inferior del sistema de Tandilia. Geología y recursos minerales de la Provincia de Buenos Aires. Relatorio del XVI Congreso Geológico Argentino. Cap. IV: 51-68. La Plata.

- Rabassa, J. (1973). Geología superficial de la Hoja" Sierras de Tandil" Provincia de Buenos Aires. LEMIT Anales 3, Serie 2, 240: 115-160. La Plata.

- Rheinheimer, G. (1987). Microbiología de aguas. Editorial Acribia S.A. ISBN: 84-200-0614-9. 299 p. Zaragoza, España.

- Romero, J. C. (1970). The movement of bacteria and viruses through porous media. Ground Water. Vol. 8 (2): 37-48.

- Ruiz de Galarreta, A., Banda Noriega, R., Granato, F. (2004). Riesgo de contaminación hídrica en el Parque Industrial de Tandil, Provincia de Buenos Aires, Argentina. Seminario Vulnerabilidad de Acuíferos. RED XVII-A (CYTED). Lima, Perú. Disponible en: http://tierra.rediris.es/hidrored/ponencias/lima/21 galarreta.html

- Ruiz de Galarreta, A. y Banda Noriega, R. (2005). Geohidrología y evaluación de nitratos del Partido de Tandil, Buenos Aires, Argentina. Actas del IV Congreso Argentino de Hidrogeología y II Seminario Hispano - Latinoamericano sobre temas actuales de la Hidrología Subterránea. Universidad Nacional de Río Cuarto. p. 99-108. Río Cuarto, Córdoba.

- Ruiz de Galarreta, A. (2006). Geohidrología y balance hidrológico de la zona no saturada en la cuenca superior del arroyo Tandileofú, Provincia de Buenos Aires. Tesis doctoral. Facultad de Ciencias Naturales y Museo. Universidad Nacional de La Plata. 181 p. La Plata.

- Ruiz de Galarreta, A., Varni, M., Banda Noriega, R., Barranquero, R. (2007). Caracterización geohidrológica preliminar en la cuenca del Arroyo Langueyú, Partido de Tandil, Buenos Aires. Actas del V Congreso Argentino de Hidrogeología. p. 119-128. Paraná, Entre Ríos.

- Sala, J. (1975). Recursos Hídricos (Especial mención de las aguas subterráneas). Geología de la Provincia de Buenos Aires. Relatorio del VI Congreso Geológico Argentino. p. 169-193. Buenos Aires.

- Sala, J., Rojo, A., Martin, E. y Ulibarrena, J. (1981). Investigaciones geohidrológicas de la cuenca de Tandil y su zona de influencia. Comisión de Investigaciones Científicas de la Provincia de Buenos Aires. La Plata. Inédito. 
- Sarmiento Sera, A., Gómez Infante, D., Guerra Díaz, L., Toledano Lavín, D., Lorenzo González, F., Rodríguez Hernández, J.C. (2003). Aplicaciones de la energía solar y la luz ultravioleta en la potabilización del agua en escuelas primarias. Revista Energética, Volumen XXIV, No. 1/2003.

- Simini, J. y Rivas Roche, C. (1980). Diagnóstico de Recursos Hídricos. Municipalidad de Tandil. Secretaria de Obras Públicas. Dirección de Industria.

- Teruggi, M. y Kilmurray, J. (1975). Tandilia. Relatorio Geología Provincia de Buenos Aires. Relatorio del VI Congreso Geológico Argentino. p. 55-77. Bahía Blanca, Buenos Aires.

- Teruggi, M. y Kilmurray, J. (1980). Sierras Septentrionales de la Provincia de Buenos Aires. En J. Turner (Ed). Geología Regional Argentina. Academia Nacional de Ciencias. Volumen II: 919956. Córdoba.

- Thornthwaite, C. W. y Mather, J. R. 1957. Instructions and tables for computing potential evapotranspiration and the water balance. Climatology Drexel Institute of Technology. Laboratory of Climatology, Publication $\mathrm{N}^{\circ}$ 10: 185-311. Centertown, N. J.

- UNICEF - Fondo de las Naciones Unidas para la Infancia. (1999). Manual sobre el agua. Hacia una mejor programación. Serie de Directrices sobre agua, medio ambiente y saneamiento. Número 2. 108 p. Nueva York, Estados Unidos.

- Varni, M. (2004). Determinación de la variación espacial de la recarga en la cuenca del Arroyo del Azul mediante el método de balance masas de cloruro. Cuadernos del Curiham. ISSN 15142906. Vol. 10: 1-15. Rosario, Santa Fe.

- WCED. (1987). Nuestro Futuro Común, Conferencia Mundial sobre el Medio Ambiente y el Desarrollo, Oxford University Press. 400 p.

- Yrigoyen, M. R. (1975). Geología del subsuelo y plataforma continental. Relatorio Geología Provincia de Buenos Aires. Actas del VI Congreso Geológico Argentino. p. 139-168. Buenos Aires.

- Zalewski, M., Janauer, G. A., Jolankaj, G. 1997. Ecohydrology: a new paradigm for the sustainable use of aquatic resources. UNESCO IHP Technical Documents in Hydrology no. 7, IHP-V Projects 2·32·4, UNESCO, Paris, France. 


\subsection{Sitios de Internet}

- ABCHoy. Portal Digital de Tandil http://www.abchoy.com.ar

- El Eco de Tandil. Diario on-line. http://www.eleco.com.ar

- Facultad de Ciencias Exactas y Naturales. Universidad de Buenos Aires. Relevamiento de la calidad del agua para consumo humano en barrios del Gran Buenos Aires (2002-2003). En el marco de la convocatoria de subsidios "Exactas con la sociedad". http://www.tallerdeaguas.com.ar

- Filtros de grava y arena verticales. Manual de instalación y operación.

http://www.fresnovalves.com.

- GWP. Global Water Partnership. http://www.gwpforum.org

- Hannah, D.M.; Wood, P.J.; Sadler, J.P. (2004) Ecohydrology and hydroecology: A new 'paradigm?' Hydrological Processes $N^{\circ}$ 8. 3439-3445. Published online in Wiley InterScience http://www.interscience.wiley.com

- Hidrored. http://tierra.rediris.es

- Instituto Tecnológico y de Estudios Superiores de Occidente (ITESO). Cátedra UNESCO (23 de mayo de 2001). http://www.catedraui.iteso.mx

- Municipio de Tandil. http://www.tandil.gov.ar

- OCED. http://www.oecd.org/env/

- Sefiltra. Purificación de fluidos. http://www.sefiltra.com

- Servicio Meteorológico Nacional. Estación 876450 (SAZT) Tandil Aeródromo. Latitud: 37.23

S; Longitud: $59.25 \mathrm{~W}$; Altitud: 175 metros. Datos de precipitaciones disponibles en http://www.tutiempo.net

- SUTEBA. Revista La Educación en Nuestras Manos. http://www.suteba.org.ar/index.php?sec=61

- Tolcachier, A. J. Medicina Ambiental. Enfermedades hídricas de alta prevalencia. Libro Virtual IntraMed. En: http://www.ambiente.gov.ar/archivos/web/salud_ambiente/File/5.pdf

- UNESCO - Programa Hidrológico Internacional http://typo38.unesco.org/en/ecohydrology.html

\subsection{Artículos periodísticos}

- Diario Nueva Era. Tandil. 28/08/2004. Consumir agua en Cerro Leones, enferma.

- Diario El Eco de Tandil. Tandil.

17/12/2008. El intendente trajo la confirmación de las obras de agua para La Elena y Cerro Leones.

09/02/2009. En Tandil, el 96 por ciento de la población accede al agua y el 79 por ciento a las cloacas.

29/04/2009. Se abrió la licitación para llevar agua potable a Cerro Leones, que costará 2,5 millones de pesos. 
M aestría en Evaluación A mbiental de Sistemas Hidrológicos - Ecohidrología

Lic. Corina Iris Rodriguez

\section{ANEXOS}




\section{ANEXO I}

Planilla de campo para el relevamiento hidrodinámico y la toma de muestras.

Sitio $\mathbf{N}^{\mathbf{0}}$ :

Fecha del censo:

\section{Datos generales}

\begin{tabular}{|l|l|l|}
\hline Propietario & \multicolumn{2}{|l|}{} \\
\hline Domicilio & \multicolumn{2}{|l|}{} \\
\hline Coordenadas planas & $\mathrm{X}=$ & $\mathrm{Y}=$ \\
\hline Fotografías & \\
\hline${\text { Encuesta } \mathrm{N}^{\mathrm{O}}}$ & \multicolumn{2}{|}{} \\
\hline
\end{tabular}

\section{Perforación y bomba.}

\begin{tabular}{|c|c|c|c|}
\hline Tipo de obra o p & & & \\
\hline Estado & & & \\
\hline Fecha de constru & & & \\
\hline Diámetro & & & \\
\hline Profundidad de 1 & & & \\
\hline Tipo de bomba & & & \\
\hline Horas de funcion & & & \\
\hline Diseño del pozo & Encamisado & $\begin{array}{l}\text { Cementación } \\
\text { Sellado } \\
\text { Engravado }\end{array}$ & Filtros \\
\hline
\end{tabular}

\section{Toma de muestra y medición del nivel freático}

\begin{tabular}{|l|l|l|}
\hline Medición del nivel freático & Cota de boca de pozo & \\
\cline { 2 - 3 } & Profundidad del agua & \\
\cline { 2 - 3 } & Altura de boca de pozo & \\
\hline Muestra $\mathrm{N}^{\mathbf{o}}$ & Conductividad & \\
\cline { 2 - 3 } & $\mathrm{pH}$ & \\
\hline
\end{tabular}

\section{Observaciones:}

\begin{tabular}{|l|l|}
\hline Accesibilidad & \\
\hline Posibilidad de toma de muestra & \\
\hline Posibilidad de medición del nivel & \\
\hline Focos contaminantes cercanos & \\
\hline Otros & \\
\hline
\end{tabular}




\section{ANEXO II}

\section{Planilla de encuesta realizada a los habitantes.}

1. Datos generales

\begin{tabular}{|l|l|l|l|}
\hline Nombre: & $\begin{array}{l}\text { Cuántas personas habitan en la } \\
\text { casa? }\end{array}$ & \\
\hline Dirección/ubicación: & Qué edades tienen? & \\
\hline Edad: & Alguno estudia actualmente? & \\
\hline Lugar de procedencia: & A qué escuela asiste: & \\
\hline Nacionalidad: & & & \\
\hline
\end{tabular}

\section{Salud}

\begin{tabular}{|l|l|l|l|}
\hline & \multicolumn{1}{|c|}{ Adultos } & \multicolumn{2}{|c|}{ Niños } \\
\hline Tienen obra social o cobertura de salud? & \multicolumn{2}{|l|}{} \\
\hline $\begin{array}{l}\text { En caso de emergencia o enfermedad a donde } \\
\text { concurre? }\end{array}$ & & & \\
\hline Cuándo fue por última vez allí? & & & \\
\hline Cuál fue el problema? & & NO & SI \\
\hline Han tenido vómitos-diarreas-gastroenteritis? & SI & & \\
\hline Cuando fue la última vez? & & & \\
\hline Con qué frecuencia le ocurre? & & & \\
\hline
\end{tabular}

\section{Maternidad}

\begin{tabular}{|l|l|l|}
\hline $\begin{array}{l}\text { Alguna de las mujeres que } \\
\text { viven en la casa está } \\
\text { embarazada? }\end{array}$ & NI & NO \\
\hline Qué edad tiene? & \multicolumn{2}{|l|}{} \\
\hline De cuantas semanas/ meses? & \multicolumn{2}{|l|}{} \\
\hline Se atiende? & SI & NO \\
\hline Donde? & \multicolumn{2}{|l}{} \\
\hline
\end{tabular}

\section{Empleo}

\begin{tabular}{|l|l|l|l|l|}
\hline & Madre & Padre & Hijos & Otros \\
\hline Trabaja? & & & & \\
\hline $\begin{array}{l}\text { Tipo de } \\
\text { trabajo? }\end{array}$ & & & & \\
\hline $\begin{array}{l}\text { Donde } \\
\text { trabaja? }\end{array}$ & & & & \\
\hline
\end{tabular}

\section{Fuentes de agua}

\begin{tabular}{|l|l|l|l|}
\hline De dónde saca el agua para & beber? & cocinar? & limpiar? \\
\hline Agua corriente & & & \\
\hline Pozo con bomba automática & & & \\
\hline Pozo con bomba manual & & & \\
\hline Aljibe/ Jagüel & & & \\
\hline Agua de lluvia & & & \\
\hline Compra agua envasada & & & \\
\hline Recibe agua (no envasada) ej: cisterna * & & & \\
\hline Otra & & & \\
\hline
\end{tabular}

\section{* Si recibe agua por camiones cisterna}

\begin{tabular}{|l|l|}
\hline Qué volumen de agua recibe? & \\
\hline Con qué frecuencia? & \\
\hline Paga por el servicio? & \\
\hline Para qué la usa? & \\
\hline Quién le brinda el agua? & \\
\hline De qué zona de la ciudad se obtiene ese agua? & \\
\hline
\end{tabular}




\section{Pozo y bomba}

\begin{tabular}{|l|l|l|}
\hline Qué tipo de bomba posee para extraer agua? & Manual & Automática \\
\hline Fecha de construcción de la perforación & \multicolumn{2}{|l|}{} \\
\hline Estado de la perforación o pozo & \multicolumn{2}{|l|}{} \\
\hline Condiciones de contorno & \multicolumn{2}{|l|}{} \\
\hline A qué profundidad llega la perforación? & \multicolumn{2}{|l|}{} \\
\hline Está encamisado? & SI & No sabe \\
\hline Hasta qué profundidad llega el encamisado? & \multicolumn{2}{|l|}{} \\
\hline De qué material son las cañerías? & \multicolumn{2}{|l}{} \\
\hline Quién fue el perforista? & \multicolumn{2}{|l|}{} \\
\hline El pozo posee cementación o sellado? & No sabe \\
\hline Realiza saneamiento o desinfección del pozo? & SI & No sabe \\
\hline Cuándo lo hizo por última vez? & \multicolumn{2}{|l}{} \\
\hline Con qué frecuencia lo realiza? & \begin{tabular}{l} 
No sabe \\
\hline $\begin{array}{l}\text { Ha recibido información sobre cómo hacer el } \\
\text { saneamiento? }\end{array}$
\end{tabular} & SI. Quién le informó? \\
\hline
\end{tabular}

\section{Almacenamiento del agua}

\begin{tabular}{|l|l|l|}
\hline Donde almacena el agua? & Tanque & Otro \\
\hline Qué capacidad tiene el tanque? (litros) & \multicolumn{2}{|l|}{} \\
\hline A qué altura de encuentra el tanque? & \multicolumn{2}{|l|}{} \\
\hline Limpia el tanque de agua? & SI & NO \\
\hline Cada cuanto? & \multicolumn{2}{|l|}{} \\
\hline Con qué lo desinfecta? & & No sabe \\
\hline $\begin{array}{l}\text { Ha recibido información sobre cómo hacer la } \\
\text { desinfección? }\end{array}$ & $\begin{array}{l}\text { SI. } \\
\text { Quién le informó? }\end{array}$ & NO \\
\hline
\end{tabular}

\section{Distribución del agua}

\begin{tabular}{|l|l|l|l|}
\hline Llega el agua por cañerías al baño? & SI & NO \\
\hline Llega el agua por cañerías a la cocina? & SI & NO \\
\hline Las cañerías poseen alguna pérdida? & SI & NO & No sabe \\
\hline Dónde está ubicado el baño? & Dentro de la casa & Fuera de la casa \\
\hline
\end{tabular}

\section{Análisis antecedentes}

\begin{tabular}{|c|c|c|c|c|}
\hline Ha realizado análisis del agua? & \multicolumn{3}{|l|}{ SI } & $\mathrm{NO}$ \\
\hline \multicolumn{5}{|l|}{ Cuándo fue la última vez? } \\
\hline \multicolumn{5}{|l|}{ Con qué frecuencia los realiza? } \\
\hline Qué tipo de análisis fueron? & $\begin{array}{l}\text { Físico- } \\
\text { químicos }\end{array}$ & $\begin{array}{l}\text { Bacterioló } \\
\text { gicos }\end{array}$ & Ambos & No sabe \\
\hline Qué resultados se obtuvieron? & & & No sabe & \\
\hline Recibió información acerca de los resultados? & \multicolumn{3}{|c|}{ SI. Quién le informó? } & NO \\
\hline Qué tipo de información le brindaron? & & & & \\
\hline
\end{tabular}


10. Efluentes domiciliarios:

\begin{tabular}{|c|c|c|c|c|}
\hline Donde se disponen los efluentes? & $\begin{array}{l}\text { Pozo } \\
\text { absorbente }\end{array}$ & $\begin{array}{l}\text { Pozo con } \\
\text { Cámara séptica }\end{array}$ & Letrina & Otro \\
\hline A qué profundidad está el pozo ciego? & & & \multicolumn{2}{|l|}{ No sabe } \\
\hline Fecha de la construcción del pozo ciego & & & \multicolumn{2}{|l|}{ No sabe } \\
\hline Estado del pozo & & & & \\
\hline Se ha desmoronado? & \multicolumn{3}{|c|}{ SI. Cuándo? } & $\mathrm{NO}$ \\
\hline Lo ha tenido que desagotar? & \multicolumn{3}{|c|}{ SI . Cuándo fue la última vez? } & $\mathrm{NO}$ \\
\hline Con qué frecuencia? & & & & \\
\hline Existe algún pozo ciego que fuera de uso? & \multicolumn{2}{|c|}{ SI. Donde? } & NO & $\begin{array}{l}\text { No } \\
\text { sabe }\end{array}$ \\
\hline \multicolumn{5}{|l|}{$\begin{array}{l}\text { A qué distancia está la perforación de los pozos } \\
\text { absorbentes (Propio y de vecinos) }\end{array}$} \\
\hline $\begin{array}{l}\text { Qué posición tiene el pozo ciego con respecto a } \\
\text { la perforación? }\end{array}$ & \multicolumn{2}{|c|}{ Aguas arriba } & \multicolumn{2}{|c|}{ Aguas abajo } \\
\hline
\end{tabular}

\section{Observaciones}




\section{ANEXO III}

\section{Balance hídrico seriado.}

Período: agosto de 2005 a septiembre de 2008 .

Localidad: Tandil.

Almacenaje considerado: $150 \mathrm{~mm}$.

\begin{tabular}{c|ccccc}
$\begin{array}{c}\text { Año } \\
\text { Mes }\end{array}$ & \multicolumn{5}{|c}{$\mathbf{2 0 0 5}$} \\
A & S & O & N & D \\
\hline ETVP & 80 & 37 & 40 & 80 & 35 \\
P-EVTP & 25 & 38 & 59 & 81 & 112 \\
Ppaa & 55 & -1 & -19 & -1 & -77 \\
Alm. & 150 & -1 & -20 & -21 & -98 \\
Var. Alm. & & -1 & -18 & -1 & -53 \\
Déficit & & & 1 & & 16 \\
Excesos & 20 & & & & \\
EVTR & 25 & 38 & 58 & 81 & 96
\end{tabular}

\begin{tabular}{ccccccccccccc} 
Año & \multicolumn{10}{c}{$\mathbf{1 0}$} \\
\hline Mes & $\mathbf{E}$ & $\mathbf{F}$ & $\mathbf{M}$ & $\mathbf{A}$ & $\mathbf{M}$ & $\mathbf{J}$ & $\mathbf{J}$ & $\mathbf{A}$ & $\mathbf{S}$ & $\mathbf{O}$ & $\mathbf{N}$ & $\mathbf{D}$ \\
\hline P & 364 & 219 & 7 & 59 & 1 & 185 & 14 & 8 & 37 & 120 & 17 & 90 \\
ETVP & 121 & 95 & 81 & 51 & 33 & 18 & 19 & 25 & 38 & 59 & 81 & 112 \\
P-EVTP & 243 & 124 & -74 & 8 & -32 & 167 & -5 & -17 & -1 & 61 & -64 & -22 \\
Ppaa & & & -74 & -62 & -94 & & -5 & -22 & -23 & & -64 & -86 \\
Alm. & 150 & 150 & 90 & 98 & 79 & 150 & 145 & 129 & 128 & 150 & 97 & 84 \\
Var. Alm. & 97 & 0 & -60 & 8 & -19 & 71 & -5 & -16 & -1 & 22 & -53 & -13 \\
Déficit & & & 14 & & 13 & & & 1 & & & 11 & 9 \\
Excesos & 163 & 124 & & & & 96 & & & & 39 & & \\
EVTR & 121 & 95 & 67 & 51 & 20 & 18 & 19 & 24 & 38 & 59 & 70 & 103 \\
& & & & & & & & & & & & \\
Año & & & & & & $\mathbf{2 0 0 7}$ & & & & & \\
\hline Mes & $\mathbf{E}$ & $\mathbf{F}$ & $\mathbf{M}$ & $\mathbf{A}$ & $\mathbf{M}$ & $\mathbf{J}$ & $\mathbf{J}$ & $\mathbf{A}$ & $\mathbf{S}$ & $\mathbf{O}$ & $\mathbf{N}$ & $\mathbf{D}$ \\
\hline P & 41 & 97 & 78 & 101 & 40 & 53 & 2 & 19 & 142 & 88 & 15 & 31 \\
ETVP & 121 & 95 & 81 & 51 & 33 & 18 & 19 & 25 & 38 & 59 & 81 & 112 \\
P-EVTP & -80 & 2 & -3 & 50 & 7 & 35 & -17 & -6 & 104 & 29 & -66 & -81 \\
Ppaa & -166 & -158 & -161 & -76 & -72 & -7 & -24 & -30 & & & -66 & -147 \\
Alm. & 49 & 51 & 51 & 101 & 108 & 143 & 127 & 122 & 150 & 150 & 96 & 55 \\
Var. Alm. & -35 & 2 & 0 & 50 & 7 & 35 & -16 & -5 & 28 & 0 & -54 & -41 \\
Déficit & 45 & & 3 & & & & 1 & 1 & & & 12 & 40 \\
Excesos & & & & & & & & & 76 & 29 & & \\
EVTR & 76 & 95 & 78 & 51 & 33 & 18 & 18 & 24 & 38 & 59 & 69 & 72
\end{tabular}




\begin{tabular}{|c|c|c|c|c|c|c|c|c|c|c|}
\hline \multirow{2}{*}{$\begin{array}{l}\text { Año } \\
\text { Mes } \\
\end{array}$} & \multicolumn{9}{|c|}{2008} & \multirow{2}{*}{$\begin{array}{c}\text { Total período } \\
2005-2008\end{array}$} \\
\hline & $\mathbf{E}$ & $\mathbf{F}$ & M & $\mathbf{A}$ & M & $\mathbf{J}$ & $\mathbf{J}$ & $\mathbf{A}$ & $\mathbf{S}$ & \\
\hline $\mathbf{P}$ & 83 & 39 & 112 & 2 & 13 & 12 & 56 & 44 & 17 & 2478 \\
\hline ETVP & 121 & 95 & 81 & 51 & 33 & 18 & 19 & 25 & 38 & 2262 \\
\hline P-EVTP & -38 & -56 & 31 & -49 & -20 & -6 & 37 & 19 & -21 & \\
\hline Ppaa & -185 & -241 & -134 & -183 & -203 & -209 & -106 & -71 & -92 & \\
\hline Alm. & 43 & 29 & 60 & 43 & 38 & 36 & 73 & 92 & 81 & \\
\hline Var. Alm. & -12 & -14 & -31 & -17 & -5 & -2 & 37 & 19 & -11 & \\
\hline Déficit & 26 & 42 & 29 & 32 & 15 & 4 & & & 10 & 325 \\
\hline Excesos & & & & & & & & & & 547 \\
\hline EVTR & 95 & 53 & 52 & 19 & 18 & 14 & 19 & 25 & 28 & 1937 \\
\hline
\end{tabular}




\begin{abstract}
ANEXO IV
Modelo de informe de análisis físico-químicos entregado.

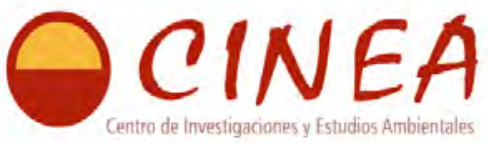

Propietario:

Dirección:

Lugar de toma de muestra:

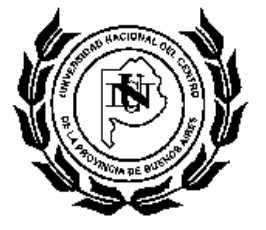

\section{$\underline{\text { Análisis físico-químico del agua }}$}

Según el Código Alimentario Argentino, en su artículo 982, modificado en 2007, el agua potable de uso domiciliario debe ser apta para la alimentación y el uso doméstico, y no deberá contener sustancias que la conviertan en peligrosa para la salud. Deberá presentar sabor agradable, ser transparente y sin olor desagradable. Dicho Código establece valores para estas características físico-químicas del agua. En este caso se han determinado la conductividad eléctrica (relacionada con la salinidad del agua) y la concentración de nitratos. Para este último ión, el valor permisible establecido es $45 \mathrm{mg} / \mathrm{l} \mathrm{NO}$.
\end{abstract}

\title{
Resultados
}

El análisis fue realizado por la Licenciada en Diagnóstico y Gestión Ambiental Corina Rodriguez, becaria del Centro de Investigaciones y Estudios Ambientales (CINEA) de la Facultad de Ciencias Humanas, en el Laboratorio de Análisis Bioquímicos y de Minerales (LAByM) del Departamento de Fisiopatología, Facultad de Ciencias Veterinarias - UNCPBA, bajo la dirección de Quiroga, Miguel A. y Landa, Roberto.

A partir de las muestras tomadas durante un año, se han determinado los siguientes valores:

\begin{tabular}{c|ccccc} 
& $\begin{array}{c}\text { Septiembre } \\
2007\end{array}$ & $\begin{array}{c}\text { Diciembre } \\
2007\end{array}$ & Marzo 2008 & $\begin{array}{c}\text { Junio } \\
2008\end{array}$ & Promedio \\
\hline $\begin{array}{c}\text { Conductividad } \\
\text { (uS/cm) }\end{array}$ & 751 & 813 & 820 & 762 & 786,5 \\
$\begin{array}{c}\text { Nitratos } \\
\text { (mg/l NO3) }\end{array}$ & 40,13 & 41,22 & 54,96 & 42,32 & 44,66
\end{tabular}

La concentración media de nitratos se encuentra dentro del valor establecido en dicho Código, aunque cerca del límite. Sería conveniente un control periódico de la presencia de dicha sustancia para tener control de sus variaciones y posibles incrementos de la misma.

Las aguas con valores de superiores a $45 \mathrm{mg} / \mathrm{l}$ de nitratos no deben ser consumidas por lactantes y mujeres embarazadas debido a que pueden generar trastornos en la hemoglobina de la sangre, que se encarga de transportar el oxígeno a través de los vasos sanguíneos y capilares. Este problema llamado metahemoglobinemia es también conocido como enfermedad de los niños azules, debido a la deficiencia de oxígeno que genera en ellos.

\section{MUCHAS GRACIAS POR SU COLABORACIÓN Y BUENA PREDISPOSICIÓN PARA LA REALIZACIÓN DE ESTE TRABAJO DE INVESTIGACIÓN}




\section{ANEXO V}

\section{Modelo de informe de análisis microbiológicos entregado.}
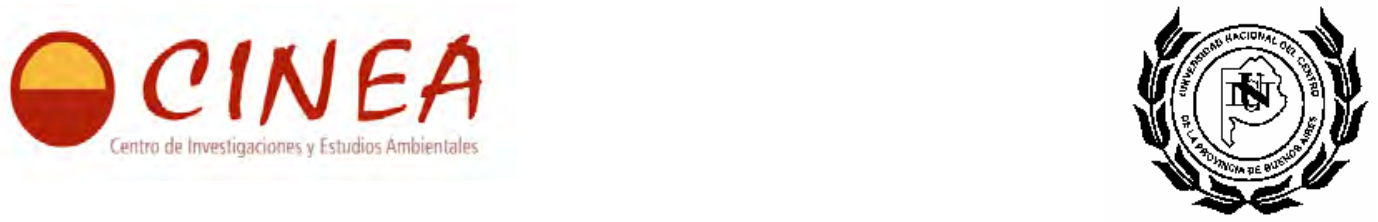

Propietario:

Dirección:

Lugar de toma de muestra:

\section{$\underline{\text { Análisis bacteriológico del agua }}$}

Nuevamente citando lo indicado en el Código Alimentario Argentino, en su artículo 982, existen los siguientes niveles permisibles en agua para consumo:

- Bacterias mesófilas: hasta 500 UFC/ml. UFC: Unidades Formadoras de Colonias

- Bacterias coliformes: hasta 3 bacterias/100 ml (NMP a $37^{\circ} \mathrm{C}$ por $48 \mathrm{hs}$ ). NMP: número más probable.

- Escherichia coli: Ausencia en $100 \mathrm{ml}$ de muestra.

- Pseudomona aeruginosa: ausencia en $100 \mathrm{ml}$ de muestra.

Algunas de las bacterias especificadas en el Código Alimentario Argentino, son patógenas y provocan trastornos gastrointestinales, pudiendo ser más importante el cuadro presentado en caso de niños, ancianos, embarazadas e inmunodeprimidos. Por lo cual es importante tener en cuenta que si el agua no cumple las condiciones de potabilidad y se realiza su consumo o empleo directo (sin hervir u otro tratamiento), se está en riesgo de enfermedad.

En el caso particular de Escherichia coli, cabe destacar que es una de las bacterias más abundantes en el tubo digestivo de los mamíferos. En condiciones normales, constituye una parte esencial de la flora bacteriana humana, a la que se atribuyen efectos beneficiosos para la salud. Sin embargo puede provocar patologías intestinales graves.

La presencia de Escherichia coli en agua, indica contaminación con material fecal humana o animal. En el caso de agua de pozo, puede existir un foco contaminante cercano, tal como un pozo séptico.

\section{Resultados}

El análisis fue realizado por la Licenciada en Diagnóstico y Gestión Ambiental Corina Rodriguez, becaria del Centro de Investigaciones y Estudios Ambientales (CINEA) de la Facultad de Ciencias Humanas, en el Laboratorio de Microbiología de Alimentos de la Facultad de Ciencias Veterinarias de la UNCPBA, bajo la dirección de la Médica Veterinaria Anahí Tabera. A partir de la muestra tomada el 21 de abril de 2008, se han determinado los siguientes valores, que se comparan con los valores permisibles en la siguiente Tabla:

\begin{tabular}{c|c|c}
\multicolumn{2}{c}{ Nivel permisible } & Valor detectado en la muestra \\
\hline Bacterias mesófilas & Hasta $500 \mathrm{UFC} / \mathrm{ml}$ & $265 \mathrm{UFC} / \mathrm{ml}$ \\
Bacterias coliformes & Hasta 3 bacterias $/ 100 \mathrm{ml}$ & 240 coliformes $/ 100 \mathrm{ml}$ \\
Escherichia coli & Ausencia $/ 100 \mathrm{ml}$ & Ausencia/100 ml \\
Pseudomona aeruginosa & Ausencia $/ 100 \mathrm{ml}$ & Presencia/100 ml
\end{tabular}


Como resultado se destaca que el agua analizada es microbiológicamente no apta para consumo.

\title{
$\underline{\text { Algunas medidas a tener en cuenta: }}$
}

En general, y siguiendo los lineamientos informados por Obras Sanitarias Tandil, se recomienda desinfectar el pozo, el tanque y las cañerías. Para ello se debe:

\section{- Desinfección del pozo:}

1) Agregar 8 a 10 litros de agua lavandina (utilizar la lavandina de uso domiciliario, cuya etiqueta indica un tenor de cloro activo de $55 \mathrm{~g} / \mathrm{l}$ ) a través de la cañería para que llegue al fondo del pozo.

2) Luego hacer funcionar la bomba y dejar correr el agua hasta que salga con olor a cloro.

3) Una vez detectado el olor, se cierran todas las canillas y se dejan las cañerías en contacto con el desinfectante por $24 \mathrm{hs}$.

4) Luego de ese plazo bombear y dejar correr el agua hasta que desaparezca el cloro residual.

\section{- Desinfección del tanque y las cañerías:}

1) Vaciar el tanque por completo.

2) Cepillar o rasquetear las paredes, la tapa y el fondo.

3) Lavar con agua eliminando toda la suciedad. Es importante no agregar limpiadores ni detergentes, solamente utilizar agua.

4) Una vez limpio, agregar la cantidad de agua lavandina concentrada necesaria (utilizar la lavandina común de uso domiciliario, cuya etiqueta indica un tenor de cloro activo de 55 g/l) según el volumen del tanque:

- $\quad$ Tanque de 100 litros = 1/4 litro de agua lavandina concentrada

- $\quad$ Tanque de 500 litros = 2 litros de agua lavandina concentrada

- Tanque de 1000 litros = 4 litros de agua lavandina concentrada

5) Agregar agua en el tanque, abrir las canillas y dejar correr el agua hasta que se perciba olor a cloro.

6) Una vez detectado el olor, se cierran todas las canillas y se dejan las cañerías en contacto con el desinfectante por 24 hs.

7) Luego de ese plazo vaciar el tanque para eliminar el cloro.

8) Llenar el tanque nuevamente con agua para su utilización.

Es importante repetir el análisis luego de un mínimo de 30 días después de la desinfección.

\author{
MUCHAS GRACIAS \\ POR SU COLABORACIÓN Y BUENA PREDISPOSICIÓN \\ PARA LA REALIZACIÓN DE ESTE TRABAJO DE INVESTIGACIÓN
}

